Maria Jamile José

\title{
A INFILTRAÇÃO POLICIAL COMO MEIO DE INVESTIGAÇÃO DE PROVA NOS DELITOS RELACIONADOS À CRIMINALIDADE ORGANIZADA
}

\author{
Dissertação de mestrado \\ Professor Orientador Dr. Antonio Magalhães Gomes Filho
}

Faculdade de Direito da Universidade de São Paulo

São Paulo, janeiro de 2010.

Maria Jamile José 


\title{
A INFILTRAÇÃO POLICIAL COMO MEIO DE INVESTIGAÇÃO DE PROVA NOS DELITOS RELACIONADOS À CRIMINALIDADE ORGANIZADA
}

\author{
Professor Orientador Dr. Antonio Magalhães Gomes Filho
}

Dissertação de mestrado apresentada perante a Comissão de Pós-Graduação da Faculdade de Direito da Universidade de São Paulo, como parte das exigências para a obtenção do título de Mestre em Direito Processual Penal.

Faculdade de Direito da Universidade de São Paulo São Paulo, janeiro de 2010. 
Àqueles que partiram. 


\section{AGRADECIMENTOS}

Agradeço, primeiramente, ao Professor Antonio Magalhães

Gomes Filho, orientador deste trabalho, cujo brilhantismo jurídico, somado à sua atenção e disponibilidade, foram de suprema importância em sua concepção.

Agradeço aos Professores Maurício Zanóide de Moraes e Gustavo Henrique Righi Ivahy Badaró, cujas sugestões e críticas formuladas durante o exame de qualificação mostraram-se indispensáveis para o amadurecimento deste estudo.

Agradeço aos Professores Antonio Scarance Fernandes, Maria Thereza Rocha de Assis Moura, José Raul Gavião de Almeida e Rogério Lauria Tucci pelas excelentes aulas ministradas durante o Curso de Pós-Graduação da Faculdade de Direito da Universidade de São Paulo.

Agradeço ao meu falecido pai, Jamil José, por incutir em mim, durante nossos curtos anos de convivência, o espírito da pesquisa e a insaciável sede do saber.

Agradeço à minha mãe, Maria Silvia Felli José, pelas inesgotáveis palavras de incentivo.

Agradeço a meus familiares, bem como a meus amigos da Faculdade de Direito das - já saudosas! - Arcadas, que me ofereceram forças sempre que o cansaço quase vencia.

Agradeço aos funcionários das bibliotecas da Faculdade de Direito do Largo São Francisco e do Instituto Brasileiro de Ciências Criminais pela valiosa assistência na obtenção do material bibliográfico para a realização desta obra.

Por fim, agradeço, de forma especial, ao meu futuro marido, Luís Fernando Silveira Beraldo, que me auxiliou nas pesquisas e na revisão deste trabalho, participou de longas discussões sobre o tema, e - acima de tudo - me ensinou a trabalhar duro, a persistir, e a, enfim, ter orgulho de todas as conquistas. 


\section{RESUMO}

Esta dissertação tem como objetivo principal o estudo da infiltração policial como meio de investigação de provas nos delitos relacionados à criminalidade organizada, em especial no ordenamento jurídico brasileiro. Para tanto, procura-se demonstrar, primeiramente, o que é o crime organizado, analisando-se a evolução legislativa em torno desde fenômeno, e salientando-se a necessidade de defini-lo juridicamente de maneira coerente. Aborda-se, também, o tema das provas no processo penal, com ênfase na sua definição e classificação; para que se possa passar, então, ao estudo dos meios de investigação de prova aplicados no combate ao crime organizado, dentre os quais se destaca a infiltração de agentes policiais. Em seguida, estuda-se a infiltração de agentes em seus pormenores, ressaltando seus antecedentes históricos, sua conceituação e objetivos, sua tipificação legal no ordenamento jurídico brasileiro, as recomendações da Convenção de Palermo acerca do tema, as modalidades de infiltração, os tipos de policiais infiltrados, e o dilema ético inerente ao meio de investigação. Recebem atenção especial as questões da responsabilização penal do agente pelas condutas praticadas na condição de infiltrado; da diferenciação entre o agente infiltrado e o agente provocador; e da possibilidade de utilização da prova obtida pelo agente infiltrado como base para a condenação. Ainda, aborda-se a problemática da oitiva do infiltrado como testemunha, e a necessidade de compatibilização deste meio de investigação de provas com as garantias constitucionais, com base no princípio da proporcionalidade. É feito, também, um breve estudo de direito comparado, com o objetivo de demonstrar as soluções encontradas por legislações de diversos países - Alemanha, Argentina, Espanha, Estados Unidos da América, França e Portugal - para a problemática em questão. Por fim, no último capítulo faz-se uma análise da proposta legislativa n. 3.731/1997, apresentada para regulamentar a figura do agente infiltrado, ora em trâmite no Senado Federal; além de um esboço de sugestão legislativa para regulamentação jurídica do agente infiltrado no Brasil. 


\begin{abstract}
This dissertation is essentially aimed at the study of the undercover agent role as means of investigation for obtaining evidence regarding crimes related to criminal organizations, mainly considering the Brazilian legal system. To so proceed, it is initially analyzed the concept of organized crime and its legislative evolution, along with the pressing necessity of creating a coherent legal definition for it. Then, it is also considered the evidence matter in criminal procedure, highlighting its definition and classification; and also regarding the means of investigation for obtaining evidence in the strive against organized crime, such as the use of undercover police officers. After this introductory section, this dissertation focuses on the undercover activity itself, pointing out its historical background, its concept and objectives, its legal definition in the Brazilian legal system, its modalities, the recommendations given by the United Nations Convention Against Transnational Organized Crime concerning the topic herein, the class of police officers who can work as undercover agents, and the ethical dilemma inherent to the activity. Also, special attention is given to the issues related to the criminal liability of the agent for the actions performed by him while undercover; to the possibility of using this evidence found by the undercover agent as grounds for conviction; and to the difference between the agent that, while undercover, merely participates in pre-existing actions, from the agent that takes active part in the criminal's decision of committing a crime. Furthermore, it is debated whether the undercover agent should be heard as a witness; and how to make this mean of investigation harmonize with the guarantees foreseen in the Brazilian Constitution, based on the principle of proportionality. In a brief Comparative Law study, it is also demonstrated the different solutions offered by several countries - Germany, Argentina, Spain, United States of America, France and Portugal - to the questions raised herein. Finally, the Bill $n$. 3.731/1997, introduced in order to regulate the activity performed by the undercover agent and currently under debate before the Brazilian Federal Senate, is examined in the last Chapter of this paper; closing with a suggestion made for a new Bill that regulates all the controversial aspects of the undercover agent character in Brazil.
\end{abstract}




\section{ÍNDICE}

INTRODUÇÃO

CAPÍTULO 1 - CRIME ORGANIZADO ........................................................... 13

1.1 Origem e desenvolvimento: as máfias italiana, chinesa e japonesa...................................13

1.2. O surgimento e a evolução da criminalidade organizada no Brasil...................................16

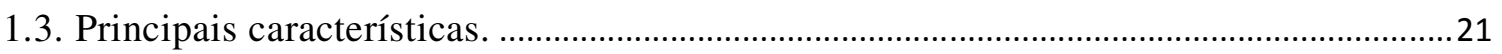

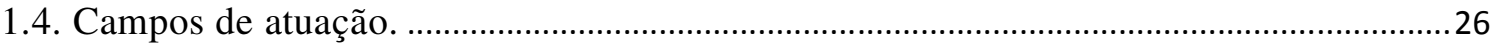

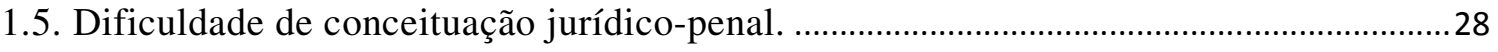

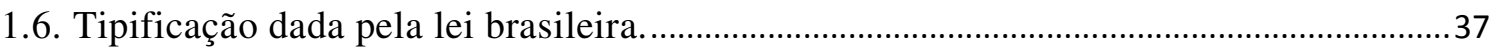

1.6.1. O Projeto de Lei n. 3.516, de 1989 ("Projeto Miro Teixeira"). ................................ 37

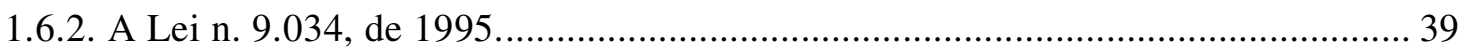

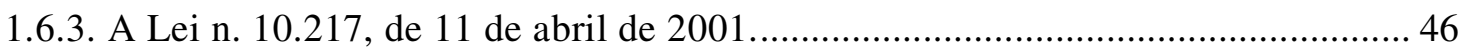

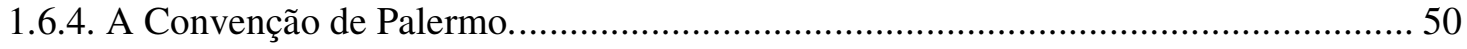

1.6.5. A imprescindibilidade da definição jurídico-penal da criminalidade

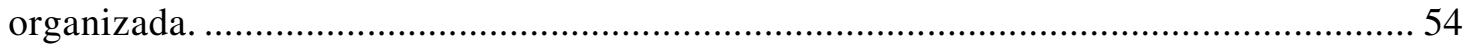

\section{CAPÍTULO 2 - CRIMINALIDADE ORGANIZADA E PROVA............................ 59}

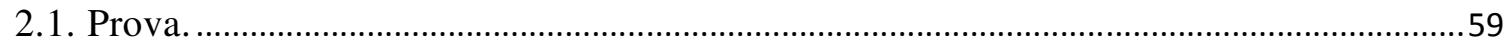

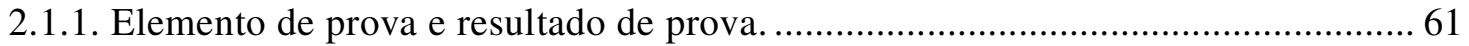

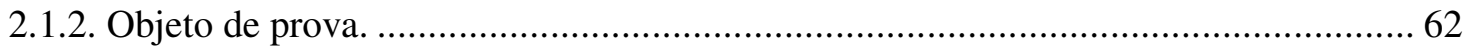

2.1.3. Fontes de prova, meios de prova e meios de investigação de prova...................... 63

2.2. Meios de investigação de prova nos delitos relacionados à criminalidade organizada.

A busca por métodos diferenciados de investigação........................................................................65

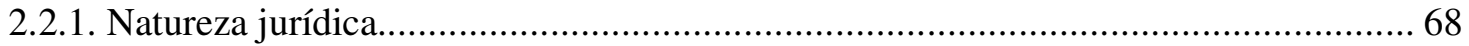

CAPÍTULO 3 - INFILTRAÇÃO POLICIAL..........................................................70

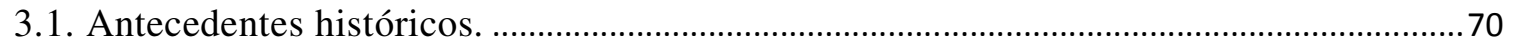

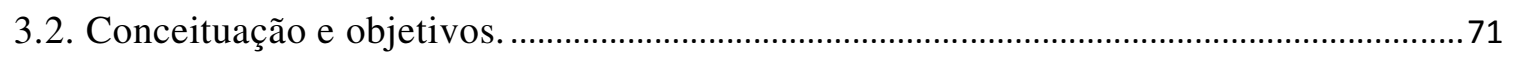

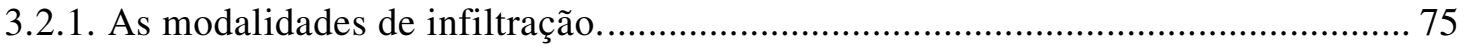


3.2.2. A prática de condutas típicas por parte do agente infiltrado e a possibilidade de sua responsabilização penal. 76

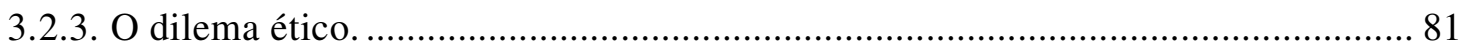

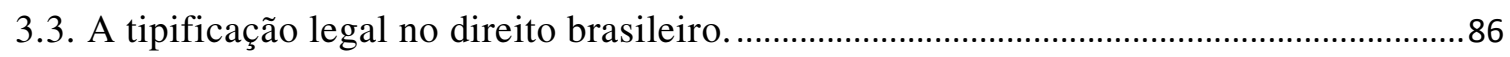

3.3.1. Os policiais que podem atuar como agentes infiltrados...................................... 91

3.3.2. As recomendações da Convenção de Palermo em relação à infiltração de agentes. 95

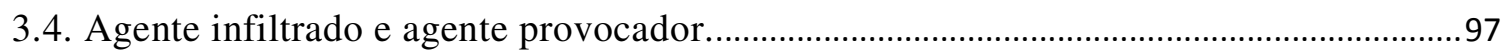

3.5. A compatibilidade constitucional da infiltração de agentes. ..............................................101

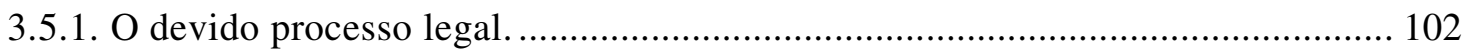

3.5.2. Princípio do contraditório. O contraditório diferido no tempo............................ 104

3.5.3. A motivação da decisão que autoriza a infiltração. ......................................... 108

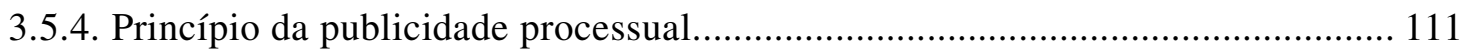

3.5.5. Presunção de inocência. Vedação da produção de prova contra si mesmo

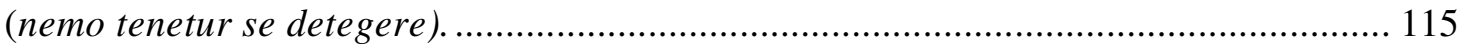

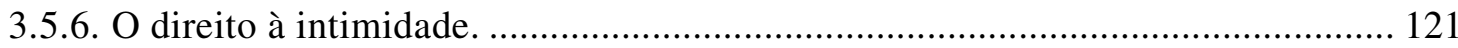

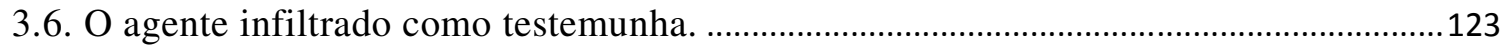

3.7. Possibilidade de utilização da prova obtida por meio da infiltração policial como

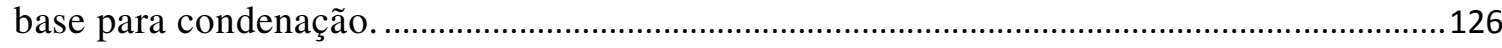

3.8. A compatibilização da figura do agente infiltrado com as garantias

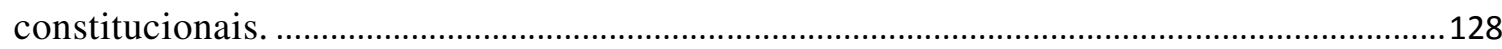

3.8.1. A eficiência e o garantismo na luta contra a criminalidade organizada. ............. 129

3.8.2. A aplicação do princípio da proporcionalidade. ........................................... 131

CAPÍTULO 4 - DIREITO COMPARADO ....................................................... 140

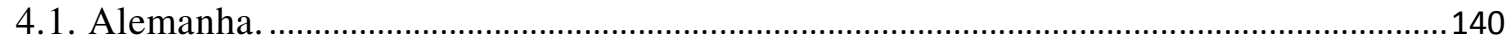

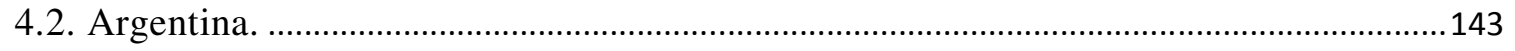

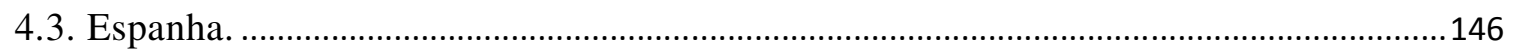

4.4. Estados Unidos da América. A entrapment defense. ........................................................149

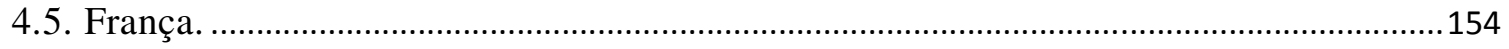

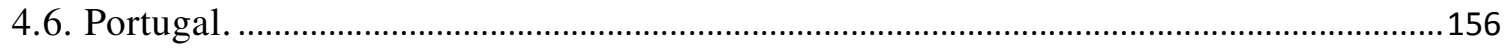

CAPÍTULO 5 - SUGESTÕES LEGISLATIVAS ..................................................... 161 
5.1. As alterações legislativas desejadas e seus motivos.

5.2. O Projeto de Lei n. 3.731/1997 do Senado Federal (n. 67/1996 da Câmara dos Deputados).

5.3. Nossa proposta de regulamentação legal.

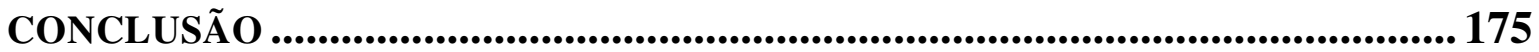

REFERÊNCIAS BIBLIOGRÁFICAS ............................................................180 


\section{INTRODUÇÃO}

Propõe-se o presente trabalho a abordar tema espinhoso na literatura jurídico-penal: o emprego do agente infiltrado como meio de investigação de prova nos delitos relacionados à criminalidade organizada no ordenamento jurídico brasileiro.

É certo que deveria ser este um tema de explanação simples e didática, vez que, resvalando nas garantias e liberdades dos cidadãos, poderia ter sido plenamente regulado por nossa legislação, em todos os seus pormenores. No entanto, não é isso que se observa: no afã de refrear a astúcia das organizações criminosas, o legislador nacional esqueceu-se, ele próprio, de ser astuto, deixando muito (ou tudo) a desejar em matéria de textos legais que tratam tanto da infiltração de agentes quanto, num plano até mesmo superior, da própria tipificação de crime organizado.

René Ariel Dotti referiu-se ao tema das organizações criminosas como um "enigma da esfinge": "a copiosa literatura e os projetos legislativos em busca de uma definição penalmente típica para esse qualificado concurso de pessoas demonstra o volume das tentativas e dos fracassos. A delinqüência astuciosa, disciplinada, corruptora e violenta, que compõe a alma e o corpo da organização criminosa e o vigor recorrente de sua existência, é o enigma com o qual a esfinge desafia muitos viajantes do sistema penal que não conseguem resolvê-lo". ${ }^{1}$

De fato, nossa legislação sobre crime organizado elaborada, como tantas outras leis nacionais, "sob o ritmo da eterna emergência", _ deixou aos intérpretes e operadores do direito um problema de proporções faraônicas: não define nem sequer o tipo penal que dá nome à lei - o crime organizado. Não determina, tampouco, como devem ser empregados os meios de investigação de provas nela previstos - dentre eles, o agente infiltrado, tema deste trabalho.

${ }^{1}$ René Ariel Dotti, A organização criminosa é uma forma qualificada do concurso de pessoas. Boletim IBCCrim. São Paulo, ano 17, n. 198, maio/2009, p. 06.

${ }^{2}$ Sergio Moccia, La perenne emergenza. Napoli: Scientifiche Italiane, 1997. 
Por outro lado, a criminalidade organizada, hoje, apresenta-se como um "abre-te sésamo"3 para desencadear o uso de um arsenal de instrumentos de intervenção das autoridades, em nome da prevenção de perigos e da elucidação de crimes. ${ }^{4}$ Conforme lembra Winfried Hassemer, "as profundas incisões nas garantias tradicionais do poder de polícia e do processo penal estão sendo operadas ou estão por acontecer sempre e invariavelmente em nome desta forma de criminalidade". 5 De fato, quando se trata da delinqüência organizada, os direitos fundamentais dos cidadãos são tratados quase como um "entrave" ao sistema penal, ao invés de serem vistos pelo que são - como base de um sistema pertencente a um Estado Democrático de Direito. ${ }^{6}$

Assim sendo, achamos por bem abordar, neste trabalho, preliminarmente, a questão do crime organizado como um todo - com ênfase na necessidade extrema de sua regulamentação legal em nosso ordenamento jurídico -, por entender que apenas a plena compreensão deste fenômeno poderá levar à percepção completa da infiltração de agentes, com todas as suas peculiaridades.

Faremos, ainda, antes de chegar ao tema principal desde estudo, uma breve incursão pelo tema das provas, para que melhor possamos classificar os resultados probatórios obtidos pelos agentes infiltrados, e analisar a possibilidade de sua utilização como base para uma condenação.

Em seguida, passaremos ao estudo da infiltração de agentes per se: abordaremos seus antecedentes históricos, seu conceito, seus objetivos, sua tipificação legal no ordenamento jurídico brasileiro, a questão da responsabilização penal do agente infiltrado, o dilema ético inerente à prática, as diferenças existentes entre o agente infiltrado e o agente provocador, as possibilidades de utilização da prova obtida pelo agente infiltrado como base para a condenação e de sua oitiva como testemunha, e a necessidade de compatibilização deste meio de investigação de provas com as garantias constitucionais, com base no princípio da proporcionalidade.

\footnotetext{
${ }^{3}$ Winfried Hassemer, Segurança pública no Estado de Direito. In: Revista Brasileira de Ciências Criminais, São Paulo, ano 2, n. 5, jan.-mar./1994, p. 57.

${ }^{4}$ Winfried Hassemer, Segurança pública..., ob. cit., p. 57.

${ }^{5}$ Winfried Hassemer, Segurança pública..., ob. cit., p. 57.

${ }^{6}$ Francis Rafael Beck, Perspectivas de controle ao crime organizado e crítica à flexibilização das garantias. São Paulo: IBCCrim, 2004, p. 107.
} 
Após, traremos as soluções encontradas pelas legislações estrangeiras - alemã, argentina, espanhola, norte-americana, francesa e portuguesa para as questões apresentadas.

Esboçaremos, ainda, ao final deste trabalho, uma sugestão legislativa para regulamentação jurídica do agente infiltrado no Brasil. Tentaremos, com tal sugestão, formular soluções para os aspectos problemáticos da atuação da figura abordada neste trabalho, buscando, sempre, o grau mínimo de agressão aos direitos e liberdades individuais garantidos por nossa Constituição da República, juntamente com o grau máximo de eficiência na investigação de provas nos delitos ligados à criminalidade organizada. 


\section{CAPÍTULO 1 - CRIME ORGANIZADO}

\subsection{Origem e desenvolvimento: as máfias italiana, chinesa e japonesa.}

O fenômeno da criminalidade organizada é, sem dúvida, secular. As associações criminosas mais antigas, pode-se dizer, são as Máfias italianas, a Yakuza japonesa e as Triads (Tríades) chinesas ${ }^{7}$. Todos esses movimentos se originaram em meados do século XVI ou início do século XVII. ${ }^{8}$ Em comum, apresentam as origens rurais, como forma de proteção das populações camponesas contra arbitrariedades cometidas por aqueles que detinham o poder, ou mesmo contra as condições de abandono e desamparo às quais eram relegadas pelo Estado. Para o desenvolvimento sem freios de suas atividades, esses movimentos contaram com a conivência, e em certos casos até mesmo com o apoio, de autoridades corruptas das regiões onde se desenvolviam. ${ }^{9}$

Cada uma das associações criminosas apontadas, no entanto, apresenta suas particularidades, e seu desenvolvimento se deu de forma notadamente diferente das demais.

A origem histórica das Máfias italianas é controversa entre os historiadores. Alguns afirmam que ela teria surgido no século XVII, outros sustentam que sua origem remonta aos tempos napoleônicos, e outros, ainda, alegam ter ela surgido durante o reinado das duas Sicílias. A versão mais comum, no entanto, é a que acomoda

\footnotetext{
${ }^{7}$ Eduardo Araújo da Silva, Crime organizado - procedimento probatório. São Paulo: Atlas, 2003, pp. 19 24.

${ }^{8}$ Em sentido contrário, Eugenio Raúl Zaffaroni afirma que o crime organizado, assim como o entendemos hoje, é fruto do século XX, não existindo fenômeno com o qual seja possível compará-lo nos tempos passados. Isso porque a criminalidade organizada, de acordo com o autor, seria concebível apenas em um mundo capitalista - sendo impossível sua existência, portanto, em um ambiente pré-capitalista. Assim, para ele “o 'organized crime' como tentativa de categorização é um fenômeno do nosso século, e de pouco vale que os autores se percam em descobrir seus pretensos precedentes históricos, mesmo remotos, porque entram em contradição com as próprias premissas classificatórias. É absolutamente inútil buscar o crime organizado na Antiguidade, na Idade Média, na Ásia ou na China, na pirataria, etc.”. (Eugenio Raúl Zaffaroni, Crime organizado: uma categorização frustrada. In: Discursos sediciosos, a. 1, v. 1. Rio de Janeiro: Relume/Dumará, 1996, p. 46).

${ }^{9}$ Eduardo Araújo da Silva, Crime organizado..., ob. cit., p. 19-24.
} 
suas origens no período de desintegração do feudalismo na península italiana, durante o qual os ricos proprietários de terra entraram em conflito com os camponeses. ${ }^{10}$ Assim, " $a$ máfia representou uma resposta para as tensões entre camponeses, aristocratas $e$ burguesia rural e entre as classes sociais e o governo central, constituindo um modo de conduzir as tensões por meio da proposta de um código específico de comportamento segundo o qual o mafioso especializava-se em ser o intermediário". ${ }^{11}$

Hoje, a máfia italiana se constitui, essencialmente, por três grandes organizações criminosas: a Cosa Nostra - atualmente a organização criminosa mais importante da Europa e uma das maiores do mundo, com sede principal na Sicília, ilha onde se originou, no início do século, XIX -, a N’Drangheta - grupo originário da região de Reggio Calabria, que se diferencia dos demais por possuir estrutura horizontal -, e a Camorra - irmandade criminosa originada na cidade de Nápoles, em 1820, como uma sociedade de autoproteção dos homens que se encontravam presos nas prisões dominadas pelos espanhóis ${ }^{12}$. Há, também, uma organização menor de destaque, a Sacra Corona Unita, originária da região de Puglia, nos anos de $1980 .^{13}$

As Triads (também conhecidas como Tríades ou Tríadas) chinesas, por sua vez, surgiram no século XVII - mais exatamente no ano de $1644^{14}$-, representando uma ampla gama de sindicatos feudais; e, em seu início, não era um grupo de criminosos, mas sim uma reunião de perseguidos políticos da Dinastia Ming, os quais se juntavam em sociedades secretas. ${ }^{15}$ Com o tempo, porém, as Triads passaram a se dedicar às atividades delituosas, com objetivos de lucro - sua primeira atuação nesse sentido foi a "venda de proteção" à população - ou seja, a prática do que hoje se conhece por extorsão. Desenvolveram-se ritos e normas internas secretas para seus membros. Mais tarde, as Triads se deslocaram para Hong Kong, e depois para Taiwan, onde voltaram-se para a

${ }^{10}$ Jean-François Gayraud, Le monde des mafias - géopolitique du crime organisé. Paris: Odile Jacob: 2005, p. 64.

${ }^{11}$ Mario Daniel Montoya, Máfia e crime organizado. Rio de Janeiro: Lumen Juris, 2007, p. 03.

${ }^{12}$ A Camorra configura o único grupo mafioso italiano cujas origens são urbanas, sendo, por isso, mais aberto e dinâmico que os demais grupos italianos, cujas origens são agrárias.

${ }^{13}$ Mario Daniel Montoya, Máfia..., ob. cit., p. 17-26.

${ }^{14}$ Rafael Pacheco, Crime organizado - medidas de controle e infiltração policial. Curitiba: Juruá, 2008, p. 22.

${ }^{15}$ Mario Daniel Montoya, Máfia..., ob. cit., p. 37. 
exploração de ópio. Posteriormente, passaram a controlar o mercado negro da heroína. ${ }^{16}$

Atualmente, existem cerca de cinqüenta Triads ativas, com um total estimado de trezentos mil membros. Entre as mais poderosas, estão a $14 \mathrm{~K}$, a $W o$ Shing Wo, a Wo On Lok, a Chu Lien Pang, a Dai Huen Chai e a Sun Yee On. Essas organizações são extremamente estruturadas e burocratizadas, e seus integrantes praticam atividades que vão desde o seqüestro de pessoas e a imigração ilegal ao tráfico de drogas e à falsificação de cartões de crédito. ${ }^{17}$

Por fim, tem-se a Yakuza japonesa, cujas origens datam do ano de 1612, quando uma crise no país deixou quase meio milhão de samurais desempregados. Sem alternativa, passaram a dedicar-se à pilhagem. Aos poucos, foram se organizando e, no século XVIII, a Yakuza já havia se transformado em uma associação criminosa propriamente dita. ${ }^{18}$

Nos tempos modernos, a Yakuza se impôs sobre os movimentos sindicais, colocando sob sua tutela os trabalhadores portuários e os da construção. No final do século XIX e início do século $\mathrm{XX}$, se aliaram aos grupos ultranacionalistas; e, após a derrota na Segunda Guerra Mundial, aproximaram-se do Partido Liberal Democrático. Possuem jornais e escritórios nas principais avenidas, além de realizar suas reuniões em público. Apesar de sempre terem se dedicado à prostituição, pornografia e lavagem de dinheiro, entre outras infrações, apenas foram considerados ilegais após os anos 1960. Hoje, conta com mais de 160.000 membros. ${ }^{19}$

É importante que se note, no entanto, que essas primeiras associações criminosas têm suas características mais alinhadas com o fenômeno da máfia do que com a criminalidade organizada em si. ${ }^{20}$ Isso porque, embora muitos estudiosos considerem tais expressões - máfia e criminalidade organizada - como sendo sinônimas, elas designam, na realidade, fenômenos de características bastante

\footnotetext{
${ }^{16}$ Rafael Pacheco, Crime organizado..., ob. cit., p. 22.

${ }^{17}$ Mario Daniel Montoya, Máfia..., ob. cit., p. 38.

${ }^{18}$ Mario Daniel Montoya, Máfia..., ob. cit., p. 10.

${ }^{19}$ Mario Daniel Montoya, Máfia..., ob. cit., p. 42.

${ }^{20}$ Mario Daniel Montoya, Máfia..., ob. cit., p. 01.
} 
distintas, existindo significativa diferença conceitual entre elas. ${ }^{21}$

É que as máfias, além de serem uma "empresa voltada à prática de crimes" ${ }^{22}$ - conforme poderiam ser grosseiramente designadas as

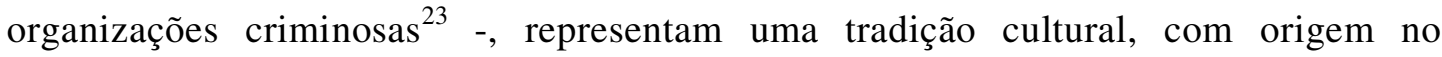
território e na família. Assim, diferentemente do que ocorre no crime organizado comum, nas máfias os laços familiares são, de fato, um importante fator de manutenção da associação criminosa e de afirmação de seu poder. ${ }^{24}$

\subsection{O surgimento e a evolução da criminalidade organizada no Brasil.}

No Brasil, o antecedente mais remoto da criminalidade organizada seria o movimento chamado cangaço, atuante no sertão nordestino entre o final do século XIX e o início do Século XX. Sua origem é atribuída a atuação dos jagunços e capangas e do próprio coronelismo nesta área geográfica, resultantes da história de colonização da região. Os cangaceiros organizavam-se de maneira hierárquica e atuavam em várias frentes ao mesmo tempo, realizando saques, extorquindo dinheiro e até mesmo praticando seqüestros. Para tanto, valiam-se de seu relacionamento com fazendeiros e chefes políticos e da colaboração de policiais corruptos, que lhes forneciam armas e munições. ${ }^{25}$

Posteriormente, no início do século $\mathrm{XX}$, surgiu a prática contravencional do conhecido "jogo do bicho", que envolve o sorteio de prêmios a apostadores, mediante o recolhimento de apostas. É o "jogo do bicho", em verdade, que é reconhecido como a primeira manifestação da criminalidade organizada no Brasil. Essa infração penal surgiu inocentemente como um jogo de azar, com a finalidade de

\footnotetext{
${ }^{21}$ Mario Daniel Montoya, Máfia..., ob. cit., p. 01.

${ }^{22}$ Marcelo Batlouni Mendroni, Crime organizado - aspectos gerais e mecanismos legais. São Paulo: Atlas: 2007, p. 06.

${ }^{23}$ A conceituação das organizações criminosas será melhor estudada nos itens 1.3, 1.4, 1.5 e 1.6, infra.

${ }^{24}$ Renata Almeida da Costa, Sociedade complexa e o crime organizado: a contemporaneidade e o risco nas organizações criminosas. Rio de Janeiro: Lumen Juris, 2004, pp. 113-114.

${ }^{25}$ Eduardo Araújo da Silva, Crime organizado..., ob. cit., p. 25.
} 
arrecadar dinheiro para salvar os animais do Jardim Zoológico do Estado do Rio de Janeiro. No entanto, a idéia foi posteriormente popularizada e patrocinada por grupos organizados, que passaram a monopolizar o jogo, mediante a corrupção de agentes públicos, como policiais e políticos. ${ }^{26}$

Atualmente, pode ser entendida como crime organizado uma gama muito maior de delitos, que vão desde o tráfico de animais silvestres até o desvio de dinheiro dos cofres públicos para contas de particulares abertas em paraísos fiscais localizados no exterior, nos casos em que tais delitos compreendem intrincada estrutura organizacional, envolvendo, não raro, funcionários de órgãos da administração indireta da União, bem como membros de todos os três Poderes do Estado. $^{27}$

Com relação à pratica dessas modalidades de delitos, esclarece Luiz Flávio Gomes que "todo diagnóstico social é muito problemático e discutível no Brasil, como sabemos, porque temos uma carência quase absoluta de investigações e dados empíricos. Apesar disso, talvez possamos arriscar que o crime organizado no nosso território ou seu lado mais saliente esteja ligado ao tráfico de drogas e de armas, corrupção (fraude contra o erário público ou contra a coletividade), furto e roubo de automóveis e roubo de cargas. "28.

Por outro lado, outras organizações criminosas mais recentes e violentas surgiram nas penitenciárias ${ }^{29}$ da cidade do Rio de Janeiro nas décadas de 70 e 80, tais como a "Falange Vermelha", o "Comando Vermelho" e o

\footnotetext{
${ }^{26}$ Eduardo Araújo da Silva, Crime organizado..., ob. cit., p. 25.

${ }^{27}$ Exemplo disso é o caso conhecido como dos “anões do orçamento", que recentemente veio a público. A partir das denúncias feitas por José Carlos Alves dos Santos, funcionários do Congresso Nacional, apurou-se que o Orçamento da União era manipulado por um esquema de corrupção do qual faziam parte governadores, ministros, senadores e deputados. Os envolvidos recebiam comissões para favorecer empreiteiras e desviavam recursos para entidades de assistência social fantasmas. As denúncias de José Carlos levaram à instalação de uma CPI. A maior parte dos integrantes da quadrilha era formada por parlamentares de pequena estatura - daí apelidar-se o caso como dos "anões do orçamento".

${ }^{28}$ Luiz Flávio Gomes e Raúl Cervini, Crime organizado: enfoques criminológico, jurídico (Lei 9.034/95) e político-criminal. São Paulo: Revista dos Tribunais, 1997, pp. 83-84.

29 Até o surgimento destes grupos organizados, existiam nos presídios líderes individuais, ou mesmo quadrilhas, que faziam valer suas determinações à massa carcerária, mas que não possuíam uma identidade que o mantivesse unido e coeso por muito tempo. (Fernando Salla, Considerações sociológicas sobre o crime organizado no Brasil. Revista Brasileira de Ciências Criminais, n. 71, ano 16, mar.-abr./2008. São Paulo: RT, 2008, pp. 374-375).
} 
“Terceiro Comando". Mais recentemente, em meados da década de 90, pode-se observar o surgimento desse tipo de organização também nos presídios do Estado de São Paulo, com a criação do "Primeiro Comando da Capital", o "PCC". 30

A origem de grupos criminosos organizados de natureza popular dentro das prisões é, de fato, uma das características mais marcantes do fenômeno da criminalidade organizada brasileira, sendo o que a distingue das formas mais comuns de emergência desses grupos nas demais partes do mundo. ${ }^{31}$

De fato, enquanto na maioria dos países as organizações criminosas surgem baseadas em identidades étnicas ou raciais, ou mesmo em afinidades criadas a partir do grupo social ao qual pertencem seus membros, ${ }^{32}$ no Brasil a criminalidade organizada popular tem por elemento agregador a prática anterior de delitos - haja visto que seus membros se conhecem nos estabelecimentos prisionais -, a própria condição dos indivíduos como encarcerados, e, ainda, certa identificação de nível social, haja visto o fato de a maior parte dos presos serem oriundos da camada mais pobre da população ${ }^{3334}$.

Dessa forma, a criminalidade principiou sua organização dentro dos presídios brasileiros na década de $1970^{35}$, no estado do Rio de Janeiro, com o surgimento do "Comando Vermelho" (CV), grupo que até hoje é um dos expoentes na criminalidade organizada brasileira. A teoria mais difundida para o seu surgimento é a que afirma ser ele o resultado da mistura de presos comuns com presos políticos dentro do mesmo estabelecimento prisional ${ }^{36}$, embora existam outras. ${ }^{37}$

\footnotetext{
${ }^{30}$ Eduardo Araújo da Silva, Crime organizado..., ob. cit., p. 26.

${ }^{31}$ Fernando Salla, Considerações..., ob. cit., p. 374.

${ }^{32}$ Fernando Salla, Considerações..., ob. cit., p. 374.

${ }^{33}$ Conforme Fernando Salla, os vínculos de natureza nacional ou regional foram considerados elementos agregadores de grupos criminosos no final do século XIX e no começo do século XX, em razão das intensas correntes migratórias observadas no país. No entanto, isso não mais ocorre. (Fernando Salla, Considerações..., ob. cit., p. 374.)

${ }^{34}$ Fernando Salla, Considerações..., ob. cit., p. 374.

35 Até o surgimento destes grupos organizados, existiam nos presídios líderes individuais, ou mesmo quadrilhas, que faziam valer suas determinações à massa carcerária, mas que não possuíam uma identidade que o mantivesse unido e coeso por muito tempo. (Fernando Salla, Considerações..., ob. cit., pp. 374-375)

${ }^{36}$ Fernando Salla, Considerações..., ob. cit., p. 374.
} 
Já nos anos 1990, a criminalidade passou a se organizar também nos presídios de São Paulo, onde o destaque é, sem dúvida, o "Primeiro Comando da Capital" (PCC) - grupo surgido em agosto de 1993 na Casa de Custódia e Tratamento "Dr. Arnaldo Amado Ferreira", em Taubaté. ${ }^{38}$ Originariamente, "Primeiro Comando da Capital" era o nome de um time de futebol que disputava o campeonato interno daquele estabelecimento prisional. Ao chegar à final do campeonato, porém, o time - composto, entre outros, pelos presos denominados "fundadores" José Marcio Felício, Cezar Augusto Roriz, José Eduardo Moura da Silva, e Idemir Carlos Ambrósio - agrediu severamente dois integrantes do time adversário, resultando na morte destes. $\mathrm{O}$ ato acabou tomando contornos de reivindicação contra as precárias condições do sistema prisional, surgindo daí a facção criminosa homônima. ${ }^{39}$ A sua existência como organização criminosa, no entanto, apenas foi reconhecida pelas autoridades quase uma década após a sua formação, em 2001 - com o evento conhecido como "Megarrebelião", durante o qual, sob o comando dos membros do "PCC", cerca de trinta estabelecimentos prisionais do estado de São Paulo, onde se localizavam 29 mil presos, entraram simultaneamente em rebelião ${ }^{40} \cdot 41$

\footnotetext{
${ }^{37}$ Interessante também é a tese formulada por Antônio Luiz Paixão a esse respeito. Contrariando a teoria geralmente aceita de que o Comando Vermelho teria surgido no Rio de Janeiro em decorrência do contato dos presos comuns com os presos políticos nos anos 1970, o autor sugere que os primeiros grupos organizados surgiram como resultado do sucesso das novas modalidades de crimes (tais como assalto a bancos, tráfico de drogas, seqüestro), as quais necessitavam da organização dos criminosos envolvidos para que tivessem bons resultados. Essas ações organizadas, por sua vez, além de resultarem em maiores ganhos econômicos para os criminosos, levavam também a um maior prestígio no mundo do crime. Quando eram presos, esses criminosos levavam o "prestígio" conquistado para dentro das cadeias, e passavam a gozar de poder sobre os demais detentos. Segundo o autor, dessa maneira passaram a surgir alianças e grupos criminosos dentro dos presídios, que levaram ao surgimento dos grupos organizados de hoje. (Antonio Luiz Paixão, Recuperar ou punir? Como o Estado trata o criminoso. São Paulo: Cortez, 1987, p. 77).

${ }^{38}$ Roberto Porto, Crime organizado e sistema prisional. São Paulo: Atlas, 2008, p. 73.

${ }^{39}$ Roberto Porto, Crime organizado..., ob. cit., p. 73.

${ }^{40}$ A "Megarrebelião" de 2001 foi a primeira das grandes ações organizadas promovidas pelo "PCC", mas não a única. De maio a agosto de 2006, um novo conjunto de rebeliões simultâneas foi posto em prática pela organização criminosa, dessa vez envolvendo um número ainda maior de estabelecimentos prisionais, e diferentemente do que havia ocorrido em 2001 - extrapolando os limites do sistema prisional, para atingir também alvos e estabelecimentos civis. Trata-se de uma das maiores crises já vividas no Brasil na área da segurança pública. Houve agressões a policiais e agentes públicos, e também a civis; atentados contra postos policiais e fóruns e também prédios privados, como bancos e supermercados; além do incêndio de veículos de transporte público. Ao todo, foram efetuados 1.325 ataques, que contabilizaram um total de 172 mortos e culminaram na paralização temporária das atividades da maior cidade do país. Em alguns bairros, foi determinado o toque de recolher. Os sentimentos de medo e insegurança, já há muito presentes entre os habitantes da cidade, foram elevados a novos patamares. (Fernando Salla, Considerações..., ob. cit., p. 365366).

${ }^{41}$ Fernando Salla, Considerações..., ob. cit., p. 366.
} 
É importante notar que o próprio ambiente prisional favoreceu por todas as maneiras o fortalecimento e manutenção dos grupos organizados no interior das prisões. As deficiências de autoridade para manutenção da ordem interna possibilitou que as lideranças das organizações se aproveitassem de toda e qualquer possibilidade de lucro no interior do sistema carcerário - tráfico de drogas, extorsão de outros presos e de familiares, controle de locais e de atividades, entre outras - para consolidar seu poder sobre os outros presos. Além disso, essas mesmas lideranças se aproveitaram da precariedade do sistema para oferecer assistência material a outros presos dentro e fora das prisões, resultando numa relação de dependência do preso para com o grupo criminoso. $^{42}$

Além disso, atuando desta maneira, os grupos criados foram estendendo sua área de atuação, também, para fora dos presídios, passando a ter participação importante em atividades criminosas lucrativas - principalmente o tráfico de drogas - nos bairros pobres do Rio de Janeiro e de São Paulo. ${ }^{43}$

Por outro lado, a própria política penal desenvolvida no Brasil no final do século $\mathrm{XX}$, em conjunto com as medidas administrativas tomadas no âmbito penitenciário no mesmo período, mostraram-se decisivas para o surgimento e desenvolvimento da criminalidade organizada nas prisões.

De um modo geral, desde os anos 1950, a política penitenciária brasileira vem sendo concebida unicamente como resposta a problemas emergenciais - tais como rebeliões, fugas, e instabilidades do sistema em geral -, inexistindo qualquer preocupação com a manutenção do sistema a longo prazo. Não se busca uma solução para os motivos que levaram às respectivas crises. ${ }^{44}$

Ora, frente ao forte sentimento de insegurança que começava a manifestar-se na sociedade a partir dos anos 1980, o legislador passou a editar leis mais rigorosas, que ostentavam penas mais longas e dificultavam ou impossibilitavam a

\footnotetext{
${ }^{42}$ Fernando Salla, Considerações..., ob. cit., p. 375.

${ }^{43}$ Fernando Salla, Considerações..., ob. cit., p. 376.

${ }^{44}$ Fernando Salla, Considerações..., ob. cit., p. 379.
} 
concessão de benefícios ao condenado. ${ }^{45} \mathrm{O}$ resultado desse endurecimento penal foi um enorme aumento no número de encarcerados dentro do sistema prisional brasileiro ("encarceramento massivo" 46 ): em treze anos, a população carcerária do Brasil triplicou (passando de 126.152 presos em 1993 para 401.236 presos em 2006) ${ }^{47}$, sem que fosse acompanhada da devida ampliação da rede penitenciária, bem como dos serviços de apoio ao preso. A superlotação nas prisões aumentou, assim como o déficit na assistência judiciária, à saúde e social - oferecida ao preso. O número de funcionários (agentes de segurança) nos presídios também não acompanhou o crescimento da população carcerária, tornando difícil a manutenção da ordem interna das prisões. ${ }^{48}$

As medidas administrativas disciplinares tomadas no âmbito interno dos presídios a partir da década de 1980 também podem ser consideradas responsáveis pela evolução da criminalidade organizada no país. Os grupos "Falange Vermelha" e "Primeiro Comando da Capital", por exemplo, são resultado direito das medidas de isolamento de presos na Ilha Grande ${ }^{49}$, no Rio de Janeiro, e no Anexo da Casa de Custódia de Taubaté ${ }^{50}$, em São Paulo, respectivamente. ${ }^{51}$

\subsection{Principais características.}

\footnotetext{
${ }^{45}$ Como exemplo desse "endurecimento penal", tem-se a Lei dos Crimes Hediondos (Lei n. 8.072, de julho de 1990), que, sozinha, contribuiu fortemente para o aumento no número de encarcerados no sistema prisional brasileiro, por prever o aumento da duração das penas privativas de liberdade e impossibilitar a progressão de regime. (Fernando Salla, Considerações..., ob. cit., p. 381).

${ }^{46}$ Expressão empregada por Fernando Salla (Considerações..., ob. cit., p. 379)

${ }^{47}$ Fernando Salla, Considerações..., ob. cit., p. 379.

${ }^{48}$ Fernando Salla, Considerações..., ob. cit., p. 379.

49 A Ilha Grande foi utilizada como sede de unidades especiais de isolamento de presos desde o final do século XIX. Nos anos 1930, foi transformada em presídio político, onde os presos eram isolados e torturados. (Fernando Salla, Considerações..., ob. cit., p. 377)

${ }^{50}$ O Anexo da Casa de Custódia de Taubaté foi inaugurado em 1985. Um pouco depois de sua inauguração, foi transformado no Centro de Readaptação Penitenciária (Dec. Estadual 23.571, de 17/06/1985), destinado a presos violentos - em geral líderes de rebeliões -, os quais eram mantidos ali sob duras condições de encarceramento e isolamento. Posteriormente, uma Resolução da Secretaria da Administração Penitenciária (SAP) instituiu o Regime Disciplinar Diferenciado (RDD), que deveria ser ali implantado. Na prática, a Resolução SAP apenas formalizava o regime disciplinar que há tempos já vinha sendo aplicado na Casa de Custódia. A Lei n. 10.792, de 10/12/2003, editada posteriormente, veio conferir legalidade ao RDD. (Fernando Salla, Considerações.., ob. cit., p. 377).

${ }^{51}$ Fernando Salla, Considerações..., ob. cit., p. 376.
} 
A expressão "criminalidade organizada" foi empregada, primeiramente, nos Estados Unidos da América, na década de 1920. Seus interlocutores eram policiais, referindo-se às atividades ilegais - praticadas, acreditavam eles, exclusivamente por estrangeiros - relacionadas à proibição estatal do consumo do álcool. Assim, o conceito era utilizado, principalmente, para identificar a máfia de origem siciliana que atuava na América, naquele ramo de atividades ilícitas. ${ }^{52}$

Hoje, a mesma expressão é empregada de maneira mais abrangente. Em verdade, o uso das expressões "crime organizado" e "organizações criminosas" na atualidade, de tão abrangente, tornou-se até mesmo inadequado. Ambas as locuções são empregadas indiscriminadamente - seja na ficção, seja na imprensa, seja pela população em geral -, resultado em um esvaziamento de seu real significado, enfraquecendo suas essências e esvaziando seus contextos. ${ }^{53}$ Contribui para a incerteza na determinação da real acepção da expressão a pluralidade de formatos assumidos pelas organizações. Conforme lembra Marcelo Mendroni, “são inúmeras as organizações criminosas que existem atualmente. Cada uma assume características próprias e peculiares, amoldadas às próprias necessidades e facilidades que encontram no âmbito territorial em que atuam. Condições políticas, policiais, territoriais, econômicas, sociais, etc., influem decisivamente para o delineamento destas características, com saliência para umas ou outras, sempre na conformidade das atuações e com o objetivo de obter maiores fontes de renda.". 54

No entanto, algumas das características apresentadas pelas organizações criminosas, embora fluidas e bastante variáveis conforme o tempo e o local de observação ${ }^{55}$, permitem, de maneira geral, distingui-las, com um bom grau de seguranças dos demais fenômenos criminológicos.

Primeiramente, observa-se uma grande acumulação de poder econômico de seus integrantes ${ }^{56}$, o que é possível uma vez que as organizações criminosas em geral desenvolvem suas atividades com o objetivo de contornar alguma

\footnotetext{
${ }^{52}$ Fernando Salla, Considerações..., ob. cit., p. 368.

${ }^{53}$ Rafael Pacheco, Crime organizado..., ob. cit., p. 36.

${ }^{54}$ Marcelo Batlouni Mendroni, Crime organizado..., ob. cit., p. 11.

${ }^{55}$ Luiz Flávio Gomes e Raúl Cervini, Crime organizado..., ob. cit., p. 73.

${ }^{56}$ Eduardo Araújo da Silva, Crime organizado... ob. cit., p. 28
} 
proibição estatal, o que, por tornar suas atividades de alto risco e diminuir a concorrência, lhes possibilita auferir extraordinários lucros. Nas palavras de Beatriz Rizzo Castanheira, "o crime organizado é antes de tudo uma forma de execução de crimes que obedece à lei básica de mercado. Oferece o que é proibido e recusado pela moral dominante e, justamente por isso, escasso. Desempenhando atividades proibidas, o risco é grande e o proveito altamente lucrativo" ${ }^{27}$.

Decorre dessa acumulação de riquezas um alto poder de corrupção $^{58}$, direcionado a autoridades de todos os poderes do Estado: Executivo, Judiciário e Legislativo - os agentes públicos participam, ou estão de alguma forma envolvidos, nas atividades da organização criminosa, auxiliando e viabilizando a sua execução. Tem-se, então, a paralisação de parte do aparelho estatal, principalmente aquela voltada para a repressão criminal, o que permite que tais organizações atuem com certa liberdade em diversos campos. ${ }^{59}$ Marcelo Mendroni lembra que esta é uma característica particularmente marcante do crime organizado no Brasil. ${ }^{60}$

A acumulação de poder econômico também gera a necessidade de "legalizar" o lucro obtido de maneira ilícita ${ }^{61}$. São imaginadas e postas à prova, por isso, as mais variadas formas de "lavagem de dinheiro", ou seja, maneiras de aplicação do dinheiro ilícito para que ele possa voltar com uma aparência lícita ao mercado financeiro. É esse, na verdade, o ponto considerado mais vulnerável nas organizações criminosas, pois os lucros por elas obtidos são astronômicos, e os mecanismos para torná-los lícitos são, via de regra, de percepção relativamente fácil

${ }^{57}$ Beatriz Rizzo Castanheira, Organizações criminosas no direito penal brasileiro: o estado de prevenção e o princípio da legalidade estrita. Revista Brasileira de Ciências Criminais. São Paulo, ano 6, n. 24, out.dez./1998, p. 108.

${ }^{58}$ Eduardo Araújo da Silva, Crime organizado... ob. cit., p. 28

${ }^{59}$ Note-se que, diferentemente de organizações político-partidárias, a criminalidade organizada não tem por objetivo a conquista do poder do Estado. Nem sequer contempla, tampouco, a possibilidade de tomá-lo à força. Pelo contrário: sua intenção é controlá-lo, tê-lo sob seu domínio, sem, no entanto, tornar-se visível. O que interessa à organização criminosa é manter-se à sombra do poder estatal e, ao mesmo tempo, impor-lhe uma influência vertical e decisiva. (Luiz Carlos Rodrigues Duarte, Princípio vitimológico e criminalidade organizada. In: Criminalidade moderna e reformas penais - Estudos em homenagem ao Prof. Luiz Luisi. Porto Alegre: Livraria do Advogado, 2001, p. 37).

${ }^{60}$ Marcelo Batlouni Mendroni, Crime organizado..., ob. cit., p. 15.

${ }^{61}$ Eduardo Araújo da Silva, Crime organizado... ob. cit., p. 29 
pelas autoridades ${ }^{62}$.

Outro traço característico das organizações criminosas é o alto poder de intimidação de que se utilizam" ${ }^{63}$. É a famosa "lei do silêncio", imposta tanto aos seus membros quanto a pessoas estranhas à organização, com o objetivo de intimidar a formação de outras organizações da mesma natureza, de obter decisões políticas favoráveis, ou de punir aqueles que revelam segredos da organização; utilizando-se, para isso, de métodos extremamente cruéis e violentos, contra a pessoa

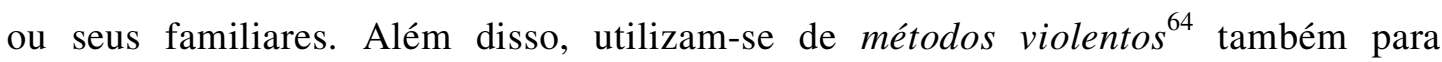
ocuparem posições proeminentes ou mesmo o monopólio do mercado, obtendo o máximo de lucro sem a necessidade de realizar grandes investimentos, reduzindo os custos e controlando a mão-de-obra.

Nos tempos atuais, a criminalidade organizada se caracteriza ainda por manter conexões locais e internacionais ${ }^{65}$, efetuando, também, a divisão de territórios para atuação. Note-se que não existem grandes obstáculos à integração das organizações criminosas no cenário internacional, uma vez que não se encontram submetidas a regras de soberania. Pelo contrário: com o desenvolvimento do processo de globalização da economia e conseqüente aproximação das nações, os grupos organizados, que até então operavam paralelamente, vislumbraram a oportunidade de expandirem seus mercados ilícitos. Esse processo de abertura econômica também teve como resultado o surgimento de novas formas de criminalidade, principalmente econômica e financeira, devido à facilidade da circulação do capital pelos mercados econômicos dos diversos países.

Tem-se, ainda, como característica do fenômeno da

\footnotetext{
${ }^{62}$ A existência de países que não fiscalizam a origem dos depósitos realizados em instituições financeiras com sede em seus territórios tem facilitado o trabalho de legalização do dinheiro ilícito obtido pelas organizações criminosas. Tais países são comumente chamados "paraísos fiscais" e podem ser citados como exemplos: Panamá, Ilhas Cayman, Uruguay e Ilhas Virgens Britânicas. As formas de envio do dinheiro para esses países são extremamente variadas: pode ser efetuado desde um contrato de câmbio até um contrato de compra e venda no qual verifica-se apenas o envio do dinheiro, sem a devida contraprestação de produtos ou serviços. Recentemente, observou-se uma grande quantidade de dinheiro sendo enviado ao exterior através das chamadas "Contas CC-5", que, devido à sua estrutura, facilitavam o cometimento da fraude. No entanto, esse tipo de conta foi posteriormente encerrado.

${ }^{63}$ Eduardo Araújo da Silva, Crime organizado... ob. cit., p. 30

${ }^{64}$ Mario Daniel Montoya, Máfia..., ob. cit., pp. 67-68.

${ }^{65}$ Eduardo Araújo da Silva, Crime organizado... ob. cit., p. 30
} 
criminalidade organizada, a sua estrutura piramidal e a sua relação com a comunidade $^{66}$. Pode-se, mesmo, comparar a divisão de tarefas nesses grupos com a estrutura de uma empresa, que conta com dezenas de "funcionários" em suas bases, que são comandados por "gerentes", que por sua vez são comandados por "diretores", e assim por diante, até que chega-se em um "chefão", que comanda a todos. Dessa forma, há grande concentração de poder nas mãos dos líderes, os quais não mantêm contato direito com as bases. ${ }^{67}$ Além disso, para ganhar a simpatia da comunidade na qual atuam e, com isso, facilitar o recrutamento de novos integrantes, realizam ampla oferta de prestações sociais, aproveitando-se para isso da omissão do aparelho estatal criando, na prática, um verdadeiro Estado paralelo. ${ }^{68}$

Sérgio Marcos de Moraes Pitombo assim discorre sobre as características da criminalidade organizada: "Outra coisa mostra-se, hoje, o 'crime organizado'. É atividade voltada ao lucro defeso, no qual os delinqüentes utilizam-se de complexo de bens e de serviços, para a prática contínua de infração ou infrações penais. Vale dizer, para além dos negócios, apenas, ilícitos. Maior surge a perenidade da associação. A estrutura emerge complexa, em razão da natureza dos fins buscados, muito mais determinados. Não dispensa direção fracionada, mas, sempre, articulada, que tende para a impessoalidade - sistema de substituição automática -, nem hierarquia funcional. Implicando, portanto, em certa burocracia e profissionalização. Possui nítido cunho internacional. Ostenta afeiçoamento externo lícito e, assim, acaba por influir, de alguma sorte, em parcela das instâncias formais do Estado. Almeja tornar-se poder paralelo e contrastante. Atinge, de modo indireto, por vezes, número

\footnotetext{
${ }^{66}$ Eduardo Araújo da Silva, Crime organizado... ob. cit., p. 30

${ }^{67}$ Antonio Scarance Fernandes, O equilíbrio entre a eficiência e o garantismo e o crime organizado. Revista Brasileira de Ciências Criminais, n. 70, ano 16, jan.-fev./2008. São Paulo: RT, 2008, p. 240.

${ }^{68}$ Luiz Carlos Rodrigues Duarte entende que, além das mencionadas supra, existe mais uma característica que deve ser atribuída à criminalidade organizada, qual seja, a gestão da informação. Para o autor, esta é uma característica importante das organizações criminosas, pois participa de suas estratégias táticas e operacionais. (Luiz Carlos Rodrigues Duarte, Princípio vitimológico..., ob.cit., p. 40). Além disso, para Antonio Scarance Fernandes, há que se considerar também como característica inerente à criminalidade organizada o uso de tecnologias avançadas. (Antonio Scarance Fernandes, O equilíbrio..., ob. cit., p. 240). Por fim, para Winfried Hassemer, a alta capacidade de dissimulação, por meio de múltiplos meios de disfarce; assim como a prática de uma ampla gama de infrações penais sem vítimas imediatas ou com vítimas difusas - e que, portanto, não são levadas diretamente ao conhecimento das autoridades pelo particular ofendido (como ocorre com a corrupção, por exemplo); e, por último mas fundamentalmente, o poder de corrupção, pela organização criminosa, do próprio sistema encarregado da persecução penal estatal, são também características importantes das organizações criminosas. (Winfried Hassemer, Segurança pública no Estado de Direito. In: Revista Brasileira de Ciências Criminais, ano 2, n. 5, jan.-mar./1994. São Paulo: Revista dos Tribunais, 1994, p. 59-60).
} 
indeterminado de vítimas" ${ }^{\text {69. }}$.

Na mesma linha, a avaliação de Alberto Silva Franco: “ $O$ crime organizado possui uma textura diversa: tem caráter transnacional na medida em que não respeita as fronteiras de cada país e apresenta características assemelhadas em várias nações; detém um imenso poder com base em estratégia global e numa estrutura organizativa que lhe permite aproveitar as fraquezas estruturais do sistema penal; provoca danosidade social de alto vulto; tem grande força de expansão compreendendo uma gama de condutas infracionais sem vítimas ou com vítimas difusas; dispõe de meios instrumentais de moderna tecnologia; apresenta um intrincado esquema de conexões com grupos delinqüenciais e uma rede subterrânea de ligações com os quadros oficiais da vida social, econômica e política da comunidade; origina atos de extrema violência; urde mil disfarces e simulações e, em resumo, é capaz de inerciar ou fragilizar os Poderes do próprio Estado"70.

Interessante, também, a análise feita por Raúl Cervini, que atribui às características da sociedade moderna o desenvolvimento em larga escala do crime organizado: "A criminalidade moderna, de modo geral, caracteriza-se pela urbanização, pelo caráter anônimo das relações humanas, pela falta de transparência das situações, pelo fracasso dos controles sociais e informais, e, precisamente, pelas grandes concentrações de poder político e econômico, pela especialização profissional, pelo domínio tecnológico e pela estratégia global, características inerentes do delito organizado" ${ }^{, 71}$.

\subsection{Campos de atuação.}

69 Sérgio Marcos de Moraes Pitombo, Crime organizado. Artigo disponível no endereço eletrônico www.sergio.pitombo.nom.br em janeiro de 2006.

${ }^{70}$ Alberto Silva Franco, Um difícil processo de tipificação. Boletim IBCCrim. São Paulo, ano 2, n. 21, set./1994.

${ }^{71}$ Raúl Cervini. Análise criminológica do fenômeno do delito organizado. Trad. De Oswaldo Henrique Duek Marques, in Ciência e política criminal, em honra de Heleno Fragoso. Org. João Marcello de Araújo Júnior. Rio de Janeiro: Forense, 1992, p. 494. 
As organizações criminosas atuam em setores bastante diversificados, até mesmo para que seu fluxo de dinheiro não seja interrompido caso eventual atuação da polícia ou da Justiça impeça ou dificulte o desenvolvimento de qualquer de suas atividades. ${ }^{72}$ Porém, pode-se afirmar que concentram suas atividades nas modalidades de ilícitos mais rentáveis, uma vez que seu objetivo é, via de regra, o lucro material. ${ }^{73}$ Por esse motivo, se expandem na sobra das proibições estatais: dedicam-se a prover bens e serviços que são proibidos oficialmente, e que, apesar da proibição estatal, tenham alta demanda. Ou seja, "as organizações criminosas nada mais fazem que capitalizar um mercado existente que não se importa com a eventual proibição em obter aquilo que deseja, pois lhe é conveniente a obtenção do resultado". ${ }^{74}$

Assim sendo, pode-se dizer que a principal atividade perpetrada pelo crime organizado é o tráfico de drogas - por muitos considerada como a "vedete do crime", e a mais clássica expressão do crime organizado ${ }^{75}$-, seguida de perto pelos crimes de colarinho branco - os quais se manifestam por meio de práticas não violentas, mas que lançam mão de formas sofisticadas de tecnologia e de altos níveis de corrupção, ao realizar condutas que configuram crimes financeiros, contra a administração pública e contra o sistema previdenciário. ${ }^{76}$

O tráfico de seres humanos, em especial de mulheres, destinadas à exploração da prostituição, é outra atividade ligada à criminalidade organizada bastante em voga na América do Sul. As mulheres são aliciadas neste continente com o objetivo de suprir a demanda européia. ${ }^{77}$

\footnotetext{
${ }^{72}$ Marcelo Batlouni Mendroni, Crime organizado..., ob. cit., p. 16.

${ }^{73}$ Rafael Pacheco, Crime organizado..., ob. cit., p. 61.

${ }^{74}$ Rafael Pacheco, Crime organizado..., ob. cit., p. 62.

${ }^{75}$ Rafael Pacheco, Crime organizado..., ob. cit., p. 62. Entre as drogas comercializadas pelas organizações criminosas, destacam-se a heroína (e demais opiáceos), antigamente produzida e vendida principalmente na região conhecida como "Triângulo Dourado" - a qual compreendia a famosa "China Branca" ("china white" ou "chinoise blanche") - e atualmente em evidência no Afeganistão e Paquistão - zona apelidada de "Crescente Dourado"; a cocaína, cujos grandes produtores nos anos 2000 têm sido a Colômbia, o Peru e a Bolívia; as anfetaminas, principalmente o chamado "ecstasy", cujos maiores produtores são a Holanda e a Bélgica e cujo consumo encontra-se em franca expansão, mormente na Europa; e o cannabis, do qual se origina tanto o "haxixe" (resina) - produzido principalmente no Marrocos e no Paquistão - e a "marijuana" produzida mormente na Colômbia, Jamaica, México, África do Sul e Nigéria. (João Davin, A criminalidade organizada transnacional - A cooperação judiciária e policial na UE. Coimbra: Almedina, 2007, pp. 14-22).

${ }^{76}$ Rafael Pacheco, Crime organizado..., ob. cit., p. 62.

${ }^{77}$ Rafael Pacheco, Crime organizado..., ob. cit., p. 62.
} 
A extorsão é também bastante praticada pelas organizações criminosas, em especial pelas máfias italianas e chinesas, e, mais recentemente, pelas "milícias" no Rio de Janeiro. De acordo com essa prática, as vítimas extorquidas - em geral, toda uma comunidade - devem pagar uma taxa à organização; do contrário, sofrerão represálias. $^{78}$

Pode-se mencionar, ainda, como atividades da criminalidade organizada, a pirataria, o contrabando, o roubo de cargas e o mercado da arte roubada. A dinâmica de todas essas práticas resume-se, em termos gerais, em suprir a demanda de uma mercadoria por produtos falsificados, roubados ou ilegais. ${ }^{79}$

Por fim, tem-se a "lavagem" de dinheiro, atividade comum a praticamente todas as organizações criminosas, haja vista sua necessidade de "legalizar" o dinheiro obtido de maneira ilícita. A metáfora ("lavagem”) refere-se ao processo de legitimação do dinheiro "sujo" no meio circulante, por meio da aplicação dos lucros obtidos ilegalmente em atividades legais, de modo que ele retorne "limpo" para alimentar a mesma atividade que lhe deu origem ${ }^{80} .81$

\subsection{Dificuldade de conceituação jurídico-penal.}

Como se procurou demonstrar até o momento, a criminalidade organizada não se resume a uma única conduta tipificada, mas engloba um complexo e variado número de condutas típicas, cercadas de diversas características

\footnotetext{
${ }^{78}$ Rafael Pacheco, Crime organizado..., ob. cit., p. 63.

${ }^{79}$ Rafael Pacheco, Crime organizado..., ob. cit., p. 63.

${ }^{80}$ Rafael Pacheco, Crime organizado..., ob. cit., p. 63.

${ }^{81}$ Eduardo Andrade Sánchez lembra, ainda, que, com sua enorme expansão, a criminalidade organizada passou a abarcar também um complexo de atividades lícitas, que se confundem com as ilítcitas, "de tal forma que el jefe de uma organización mafiosa puede aparecer como un próspero comerciante y su actividad quedar encuadrada dentro de um marco de legalidad, pese a estar basada en la criminalidad". (Eduardo Andrade Sánchez, Instrumentos jurídicos contra el crimen organizado. Universidade Autónoma de México Poder Judicial de la Federación: México, 1997, p. 25) Tal prática é empregada até mesmo com o propóstito de facilitar a "lavagem" do dinheiro "sujo" da organização, conforme visto acima (Rafael Pacheco, Crime organizado..., ob. cit., p. 63).
} 
singulares. $^{82}$ Nas palavras de Guillermo J. Yacobucci, "la noción de 'crimen organizado' envuelve uma pluralidad de aspectos que no se acomodan fácilmente a los criterios dominantes en materia penal. Por eso las dudas sobre sus fundamentos, sobre su propria capacidad de rendimiento como concepto explicativo y, a la vez, sobre las formas que deben adoptar las decisiones legales a su respecto". ${ }^{8}$

Dessa forma, tem-se que o processo clássico de tipificação penal, modelado para as condutas individualizadas observadas ao longo do século XIX e meados do século XX, passou a ser insuficiente para tutelar as condutas que compõem o crime organizado. ${ }^{84} \mathrm{O}$ uso dos tipos penais contra o crime organizado requere uma estrutura penal e processual diferente dos delitos clássicos. ${ }^{85}$ Conforme sustenta René Ariel Dotti, "é notório o fracasso das tentativas para tipificar taxativamente um fato social que se assemelha a um caleidoscópio pela mutação contínua na composição de seus membros, na estratégia de ação, nos processos de corrupção e de intimidação, além de outros componentes". ${ }^{86}$

Nas palavras de Mario Daniel Montoya, "Os instrumentos tradicionais do Estado liberal de direito fracassaram na luta contra a criminalidade organizada. Por essa razão, os poderes públicos precisam contar com novos meios, tanto de direito penal material quanto de direito processual, meios estes que serão mais agressivos contra os autores". 87

\footnotetext{
${ }^{82}$ Julio E. S. Virgolini lembra, ainda, que a complexidade do fenômeno da criminalidade organizada não se limita às modalidades fáticas que assume, mas vai além, ao colocar em contato zonas pouco expostas nos estudos das ciências sociais: "al introducir el crimen en el análisis del orden social, no desde el punto de vista de la agresión, sino desde el de su creación y reproducción, el concepto de crimen organizado, como el delito de cuello branco e o de la corrupción, tiene la virtud de disolver las barreras que siempre separaron al crimen de la política. Al poner em contacto ambas zonas, de una forma contrastante con los modos del discurso tradicional de las ciencias sociales, revela la esencial ambigüedad del discurso de la criminologia em general y de la actuación del derecho en particular”. (Julio E. S. Virgolini, Crimen organizado: criminología, derecho y política. In: Nada personal... Ensayos sobre crimen organizado y sistema de justicia. Buenos Aires: Depalma, 2001, p. 37).

${ }^{83}$ Guillermo J. Yacobucci, Política criminal y delincuencia organizada. In: El crimen organizado - Desafíos y perspectivas en el marco de la globalización. Buenos Aires: Editorial Ábaco de Rodolfo Depalma, 2005, p. 26.

${ }^{84}$ Rafael Pacheco, Crime organizado..., ob. cit., p. 64.

85 Guillermo J. Yacobucci, Los tipos penales relacionados con el crimens organizado. In: El crimen organizado - Desafíos y perspectivas en el marco de la globalización. Buenos Aires: Editorial Ábaco de Rodolfo Depalma, 2005, p. 122.

${ }^{86}$ René Ariel Dotti, A organização criminosa..., ob. cit., p. 06.

${ }^{87}$ Mario Daniel Montoya, Máfia..., ob. cit., p. 166.
} 
É por esse motivo que se considera que as características singulares apresentadas pela criminalidade organizada contemporânea repercutiram na moderna dogmática penal. Conforme afirma Eduardo Araújo da Silva, "a tipificação do crime organizado é considerada um dos grandes desafios para o Direito Penal no século XXI, pois com base em um conceito delimitado será possível optar com maior segurança por um dos caminhos que se apresentam para o tratamento normativo do tema ${ }^{, 88}$.

De fato, a elaboração de um conceito de criminalidade organizada não é uma questão pacífica, tanto pela complexidade das condutas criminais de caráter organizado, quanto pelas diversas normas já existentes acerca da matéria em diversos países. ${ }^{89}$ Para Eugenio Raul Zaffaroni, a dificuldade vem do fato de que todas as tentativas de categorização partem de modelos que não refletem o conhecimento obtido por dados empíricos. ${ }^{90}$ Já para Beatriz Rizzo Castanheira, por outro lado, a grande dificuldade está no fato de que seria impossível identificar o bem jurídico atingido pela criminalidade organizada, uma vez que seus membros se dedicam à prática de diversas infrações penais. A solução encontrada para tal problema parece ser a de designar para o tipo penal um bem jurídico genérico a ser protegido, qual seja, a paz pública - o qual, de acordo com a autora, pode englobar "potencialmente tudo".91 Essa solução, porém, traria consigo um problema: “quando o Direito penal caminha dos bens jurídicos difusos, ou supra-individuais, e chega ao tipo de perigo abstrato, cai a máscara do Estado liberal, tolerante para com a liberdade de consciência e da esfera individual do agir, e entra em cena o Estado de prevenção"92.

Observa-se que a tendência atual é "dividir" o fenômeno crime organizado em três fatores que se complementam ${ }^{93}$ : o estrutural, que diz respeito ao número mínimo de pessoas que devem participar das atividades para que elas sejam

\footnotetext{
${ }^{88}$ Eduardo Araújo da Silva, Crime organizado..., ob. cit., p. 33.

${ }^{89}$ Manuel Cancio Meliá e Paula Andrea Ramírez Barbosa, Crime organizado - Tipicidade, política criminal, investigação e processo - Brasil, Espanha e Colômbia. Coord.: André Luís Callegari. Porto Alegre: Livraria do Advogado, 2008, p. 67.

${ }^{90}$ Eugenio Raul Zaffaroni, Crime organizado..., ob. cit., pp. 48-49.

${ }^{91}$ Beatriz Rizzo Castanheira, Organizações criminosas..., ob. cit. p. 118.

92 Beatriz Rizzo Castanheira, Organizações criminosas..., ob. cit. p. 118.

${ }^{93}$ Rafael Pacheco, Crime organizado..., ob. cit., p. 47.
} 
consideradas como organização criminosa; o finalístico, que apresenta um rol de crimes a ser considerado como de criminalidade organizada; e o temporal, que se reporta à permanência e reiteração do vínculo associativo. ${ }^{94}$

Seguindo essa metodologia, vêm sendo elaboradas, ao redor do globo, diversas definições de crime organizado, na tentativa de tentar sistematizar o fenômeno. ${ }^{95}$ Em geral, as definições produzidas apresentam em sua estrutura os três fatores mencionados supra; algumas apresentam apenas dois deles. Há ainda variações: algumas das definições incluem, no quesito finalístico, o objetivo de obter lucro financeiro - ou algum outro tipo de vantagem - por parte da organização; e outras, ainda, mencionam a participação de agentes públicos nas atividades ilícitas.

A Convenção da Organização das Nações Unidas sobre a Delinqüência Organizada Transnacional, realizada no período de 12 a 15 de novembro de 2000 em Palermo, na Itália, produziu a chamada "Convenção de Palermo", o qual, em seu artigo $2^{\circ}$, define organização criminosa como “a structured group of three or more persons, existing for a period of time and acting in concert with the aim of committing one or more serious crimes or offences established in accordance with this Convention, in order to obtain, directly or indirectly, a financial or other material benefict". ${ }^{96}$ Deve-se observar que o conceito apresentado abrange os quesitos estrutural, temporal e finalístico. Note-se, ainda, que, de acordo com a tendência observada atualmente no plano internacional, acrescentou-se a finalidade econômica como requisito para diferenciar, no plano jurídico-penal, os conceitos de organização criminosa e de terrorismo - o qual concentra suas finalidades no plano ideológico, e não no econômico. ${ }^{97}$

O Conselho da Europa também elaborou, recentemente, uma definição formal de grupo criminal organizado, a qual está contida na Recomendação 11

\footnotetext{
${ }^{94}$ Eduardo Araújo da Silva, Crime organizado... ob. cit., p. 35.

${ }^{95}$ Nas oportunas palavras de Jay Albanese, "there seem to be as many descriptions of organized crime as there are authors”. (Jay Albanese, Organized crime in America. Cincinnati: Anderson, 1985, p. 34).

96 O texto integral da Convenção de Palermo encontra-se disponível no endereço eletrônico: http://www.uncjin.org/Documents/Conventions/dcatoc/final_documents_2/convention_eng.pdf, acessado em 09 de dezembro de 2009. Note-se que preferimos utilizar, neste trabalho, a versão original em inglês do texto da referida Convenção devido às diferenças de tradução existentes na versão em português, como se verá no Item 1.6.4, infra.

97 Eduardo Araújo da Silva, Crime organizado... ob. cit., p. 35. A Convenção de Palermo será melhor estudada no Item 1.6.4, infra.
} 
do Comitê de Ministros sobre Princípios e Diretrizes na Luta contra o Crime Organizado, de 2001, e conceitua organização criminosa como "un grupo estructurado de tres o más personas existente por um periodo de tiempo y actuando concertadamente com el propósito de cometer uno o más delitos graves - entendiendo por tales los castigados com 4 o más años de prisión - para obtener directamente um beneficio financiero o material. "98

Alguns órgãos ligados à persecução penal e à repressão da criminalidade também elaboraram suas próprias tentativas de definição. O Federal Bureau of Investigation (FBI), nos Estados Unidos da América, por exemplo, conceitua crime organizado como "any group having some manner of a formalized structure and whose primary objective is to obtain money through illegal activities. Such groups maintain their position through the use of actual or threatened violence, corrupt public officials, graft, or extortion, and generally have a significant impact on the people in their locales, region, or the country as a whole”. 99 Já a Interpol, a maior organização policial internacional do mundo - contando com 187 países-membros ${ }^{100}$-, entende o crime organizado como qualquer empresa ou grupo de indivíduos que tomem parte em uma atividade ilegal contínua, cujo objetivo principal seja a obtenção de lucro, e se desenvolva para além das fronteiras nacionais dos países. ${ }^{101}$

Estudiosos do tema e doutrinadores também oferecem seus conceitos, na tentativa de resumir, em uma definição única, o fenômeno multifacetário da criminalidade organizada.

Jorge de Figueiredo Dias entende organizações criminosas por grupos que cometem “crimes cuja prática planeada é presidida por intuitos de lucro ou força, que em si e no seu conjunto se apresentam de alta gravidade e nos quais actuam concertadamente pelo menos mais de dois comparticipantes, por tempo duradoiro $e$ indeterminado, com divisão de tarefas: crimes em cuja prática se utiliza ou planeja se

\footnotetext{
${ }^{98}$ Isabel Sánchez García de Paz, La criminalidad organizada - aspectos penales, procesales, administrativos y policiales. Madrid: Dykinson, 2005, p. 33.

${ }^{99}$ Definição extraída do endereço eletrônico: http://www.fbi.gov/hq/cid/orgcrime/glossary.htm, acessado em 30 de outubro de 2008.

${ }^{100}$ Informações extraídas do endereço eletrônico http://www.interpol.int/, acessado em 31 de outubro de 2008

${ }^{101}$ Mario Daniel Montoya, Máfia..., ob. cit., p. 188.
} 
utilizar estruturas empresariais, societárias ou análogas, ou usar da força ou se planeja utilizar estruturas a causar medo, ou servir-se da influência da política, da mídia, da administração pública ou da economia." "102 Além disso, para o mesmo autor, o conceito jurídico-penal do tipo penal "criminalidade organizada" deve compreender a prática do crime de participação em organização criminosa juntamente com a prática, por essa mesma organização, de outros crimes - de maneira consumada, tentada ou mesmo apenas no estágio da preparação. Esses crimes, no entanto, devem ser de particular natureza e gravidade, e devem estar contidos em um rol ( "catálogo",103) determinado por lei. ${ }^{104}$

Yann Bisiou propõe definir crime organizado como "actes commis par um groupe d'individus, réunis au sein d'une structure criminelle hiérarchisée mettant en ouvre un Project criminel, destiné à fournir aux membres du groupement lês moyens de leur subsistance. Dès lors, la nature des infractions commises est indifférente". 105

Para Howard Abadinsky, "organized crime is a nonideological enterprise involving a number os persons in close social interaction, organized on a hierarchical basis, with at least three levels/ranks, for the purpose of securing profit and power by engaging in illegal and legal activities". ${ }^{106}$

Winfried Hassemer, por sua vez, ressalva que o conceito jurídico-penal de criminalidade organizada não pode se restringir à mera participação em grupos organizados ou à atividade criminosa habitual, ainda que planejada com grande astúcia e dissimulação, pois essas são atividades já velhas conhecidas da sociedade e do legislador $^{107}$. Se o conceito produzido se resumisse a estas características, não haveria nele nada de novo, apenas "o crescimento ou a modernização quantitativa de fenômenos dos

102 Jorge de Figueiredo Dias, A criminalidade organizada: do fenómeno ao conceito jurídico-penal. In: Revista Brasileira de Ciências Criminais, n. 71, ano 16, mar.-abr./2008. São Paulo: Revista dos Tribunais, 2008, p. 26.

103 Expressão empregada pelo autor, o qual ressalva, ainda, que este "catálogo"deve ser formulado necessariamente pelo legislador, não cabendo à doutrina, em hipótese alguma, ampliá-lo ou reduzi-lo. (Jorge de Figueiredo Dias, A criminalidade organizada..., ob. cit., p. 26-27).

${ }^{104}$ Jorge de Figueiredo Dias, A criminalidade organizada..., ob. cit., p. 26-27.

${ }^{105}$ Yann Bisiou, Le concept..., ob. cit., p. 645.

${ }^{106}$ Howard Abadinsky, Organized crime. Chicago: Nelson Hall, 1992, p. 29.

${ }^{107}$ Winfried Hassemer, Segurança pública..., ob. cit., p. 59. 
quais a legislação policial, penal e processual penal trata desde longa data”"108. Assim, segundo o autor, uma vez que o crime organizado é prática que contém enorme potencial de dano, "um conceito útil de criminalidade organizada precisa isolar um potencial de ameaça qualitativamente novo"109.110

No âmbito do direito comparado, são observadas as mais diversas soluções para a problemática da tipificação e conceituação jurídico-penal da criminalidade organizada.

O ordenamento jurídico italiano, por exemplo, trata o crime organizado como um crime contra a ordem pública. Assim, o Codice Penale italiano prevê, em seu artigo $416^{111}$, a figura da "associação para delinquir" ("associazione per delinquere”), cujo requisito único é o quantitativo - devem existir três ou mais pessoas

${ }^{108}$ Winfried Hassemer, Segurança pública..., ob. cit., p. 59.
${ }^{109}$ Winfried Hassemer, Segurança pública..., ob. cit., p. 59.

${ }^{110}$ No mesmo sentido, Beatriz Rizzo Castanheira: "A existência de grupos mais ou menos organizados, ainda que atuem com base profissional e de forma habitual - estável - não é o suficiente para a distinção que buscamos. Sempre houve criminalidade cometida por grupos, bandos, cujas características principais - número de participantes, estabilidades e união em torno de uma finalidade criminosa comum -, portanto, nada acrescentam". (Beatriz Rizzo Castanheira, Organizações criminosas..., ob. cit. p. 105).

111 "Art. 416. Quando tre o piu' persone si associano allo scopo di commettere piu' delitti, coloro che promuovono o costituiscono od organizzano l'associazione sono puniti, per cio' solo, con la reclusione da tre a sette anni. Per il solo fatto di partecipare all'associazione, la pena e' della reclusione da uno a cinque anni. I capi soggiacciono alla stessa pena stabilita per i promotori. Se gli associati scorrono in armi le campagne o le pubbliche vie si applica la reclusione da cinque a quindici anni. La pena e' aumentata se il numero degli associati $e^{\prime}$ di dieci o piu'. Chiunque fa parte di un'associazione di tipo mafioso formata da tre o piu' persone, e' punito con la reclusione da tre a sei anni. Coloro che promuovono, dirigono o organizzano l'associazione sono puniti, per cio' solo, con la reclusione da quattro a nove anni. L'associazione é di tipo mafioso quando coloro che ne fanno parte si avvalgono della forza di intimidazione del vincolo associativo e della condizione di assoggettamento e di omerta' che ne deriva per commettere delitti, per acquisire in modo diretto o indiretto la gestione o comunque il controllo di attivita' economiche, di concessioni, di autorizzazioni, appalti e servizi pubblici o per realizzare profitti o vantaggi ingiusti per se' o per altri ovvero al fine di impedire od ostacolare il libero esercizio del voto o di procurare voti a se' o ad altri in occasione di consultazioni elettorali. Se l'associazione e' armata si applica la pena della reclusione da quattro a dieci anni nei casi previsti dal primo comma e da cinque a quindici anni nei casi previsti dal secondo comma. L'associazione si considera armata quando i partecipanti hanno la disponibilita', per il conseguimento della finalita' dell'associazione, di armi o materie esplodenti, anche se occultate o tenute in luogo di deposito. Se le attivita' economiche di cui gli associati intendono assumere o mantenere il controllo sono finanziate in tutto o in parte con il prezzo, il prodotto, o il profitto di delitti, le pene stabilite nei commi precedenti sono aumentate da un terzo alla meta'. Nei confronti del condannato e' sempre obbligatoria la confisca delle cose che servirono o furono destinate a commettere il reato e delle cose che ne sono il prezzo, il prodotto, il profitto o che ne costituiscono l'impiego. Decadono inoltre di diritto le licenze di polizia, di commercio, di commissionario astatore presso i mercati annonari all'ingrosso, le concessioni di acque pubbliche e i diritti ad esse inerenti nonche' le iscrizioni agli albi di appaltatori di opere o di forniture pubbliche di cui il condannato fosse titolare . Le disposizioni del presente articolo si applicano anche alla camorra e alle altre associazioni, comunque localmente denominate, che valendosi della forza intimidatrice del vincolo associativo perseguono scopi corrispondenti a quelli delle associazioni di tipo mafioso". 
associadas com o fim de cometer delitos. ${ }^{112}$ Tal definição legal, no entanto, é criticada por tornar bastante difícil a distinção entre a quadrilha ou bando e a organização criminosa. Para solucionar tal dificuldade, a doutrina italiana vem procurando encontrar critérios outros - além do número de pessoas envolvidas no delito - que possam explicitar certo vínculo de permanência entre tais pessoas envolvidas, para, então, considerar uma conduta como sendo típica de organização criminosa. ${ }^{113}$

A legislação francesa, por outro lado, faz a distinção entre quadrilha ou bando e organização criminosa, porém sem determinar o número de pessoas que devem participar das atividades delituosas para que esta última se caracterize. Dessa forma, o artigo 450-1 do Code Penale francês prevê que se configura como organização criminosa o grupo organizado de maneira estável, com a finalidade de cometer delitos graves - assim entendidos como aqueles apenados com mais de dez anos de prisão. Em geral, tais delitos são aqueles relacionados ao tráfico de drogas, armamentos ou terrorismo. $^{114}$

O Código Penal espanhol, por sua vez, não conceitua crime organizado, entendendo o fenômeno como "espécie" do "gênero" "associação para delinqüir" (artigo 515.2 $2^{115}$ do Código Penal espanhol), e deixando sua definição a cargo do artigo 282 bis, n. 4, da Ley de Enjuiciamiento Criminal $^{116}$, com a redação dada pela Ley

112 Guillermo J. Yacobucci, Los tipos penales relacionados con el crimen organizado. In: El crimen organizado - Desafíos y perspectivas em el marco de la globalización. Coord.: Guillermo J Yacobucci. Buenos Aires: Editorial Ábaco de Rodolfo Depalma, 2005, p. 97.

113 Gaetano Insolera, I delitti contro l'ordine pubblico. In: Diritto penale. Lineamenti di parte especiale. Bologna: Monduzzi, 2000, p. 221.

${ }^{114}$ Guillermo J. Yacobucci, Los tipos penales..., ob. cit., p. 97.

115 “Art. 515. Son punibles las asociaciones ilícitas, teniendo tal consideración:

$1^{\circ}$. Las que tengan por objeto cometer algún delito o, después de constituidas, promuevan su comisión, así como las que tengan por objeto cometer opromover la comisión de faltas de forma organizada, coordinada y reiterada.

$2^{\circ}$. Las bandas armadas, organizaciones o grupos terroristas.

$3^{\circ}$. Las que, aun teniendo por objeto un fin lícito, empleen medios violentos o de alteración o control de la personalidad para su consecución.

$4^{\circ}$. Las organizaciones de carácter paramilitar.

$5^{\circ}$ Las que promuevan la discriminación, el odio o la violencia contra personas, grupos o asociaciones por razón de su ideología, religión o creencias, la pertenencia de sus miembros o de alguno de ellos a una etnia, raza o nación, su sexo, orientación sexual, situación familiar, enfermedad o minusvalía, o inciten a ello”.

116 “Art. 282 bis. A los fines previstos en el artículo anterior y cuando se trate de investigaciones que afecten a actividades propias de la delincuencia organizada, el Juez de Instrucción competente o el Ministerio Fiscal dando cuenta inmediata al Juez, podrán autorizar a funcionarios de la Policía Judicial, mediante resolución 
Organica 5/1999 - o qual trata, na verdade, da figura do agente encoberto, e traz a definição de crime organizado de maneira meramente au passant. ${ }^{117}$ De acordo com o referido dispositivo legal, é considerada organização criminosa para o direito espanhol toda associação de três ou mais pessoas, dotada de permanência e/ou reiteração, que se dedique à prática de condutas que tenham como fim o cometimento de algum dos delitos enumerados no texto da lei, quais sejam: seqüestro; prostituição; delitos contra o patrimônio e contra a ordem sócio-econômica; delitos contra os direitos dos trabalhadores; tráfico de espécies de flora ou fauna ameaçada de extinção; tráfico de material nuclear e

fundada y teniendo en cuenta su necesidad a los fines de la investigación, a actuar bajo identidad supuesta y a adquirir y transportar los objetos, efectos e instrumentos del delito y diferir la incautación de los mismos. La identidad supuesta será otorgada por el Ministerio del Interior por el plazo de seis meses prorrogables por períodos de igual duración, quedando legítimamente habilitados para actuar en todo lo relacionado con la investigación concreta y a participar en el tráfico jurídico y social bajo tal identidad.

(...)

4. A los efectos señalados en el apartado 1 de este artículo, se considerará como delincuencia organizada la asociación de tres o más personas para realizar, de forma permanente o reiterada, conductas que tengan como fin cometer alguno o algunos de los delitos siguientes:

a. Delito de secuestro de personas previsto en los artículos 164 a 166 del Código Penal.

b. Delitos relativos a la prostitución previstos en los artículos 187 a 189 del Código Penal.

c. Delitos contra el patrimonio y contra el orden socioeconómico previstos en los artículos 237, 243, 244, 248 y 301 del Código Penal.

d. Delitos relativos a la propiedad intelectual e industrial previstos en los artículos 270 a 277 del Código Penal.

e. Delitos contra los derechos de los trabajadores previstos en los artículos 312 y 313 del Código Penal.

f. Delitos de tráfico de especies de flora o fauna amenazada previstos en los artículos 332 y 334 del Código Penal.

g. Delito de tráfico de material nuclear y radiactivo previsto en el artículo 345 del Código Penal.

h. Delitos contra la salud pública previstos en los artículos 368 a 373 del Código Penal.

i. Delito de falsificación de moneda previsto en el artículo 386 del Código Penal.

j. Delito de tráfico y depósito de armas, municiones o explosivos previsto en los artículos 566 a 568 del Código Penal.

k. Delitos de terrorismo previstos en los artículos 571 a 578 del Código Penal.

l. Delitos contra el Patrimonio Histórico previstos en el artículo 2.1.e de la Ley Orgánica 12/1995, de 12 de diciembre, de represión del contrabando”.

${ }^{117}$ Para muitos, a referida Lei é dotada de extrema importância, uma vez que foi responsável pela positivação do conceito de crime organizado no ordenamento espanhol. (Nesse sentido, Sílvia Planet Robles, Políticas de seguridad y prevención em el estado español em matéria de delincuencia organizada. In: La seguridad em la sociedad del riesgo - um debate abierto. Barcelona: Atelier, 2003, p. 171). No entanto, não se pode deixar de notar que ela foi promulgada, em verdade, para regular a figura do agente encoberto, meio de investigação de provas nos delitos relacionados ao crime organizado, e não para elaborar uma definição de organização criminosa em si. Tal definição, dessa forma, fica relegada a um segundo plano, sendo abordada apenas "de passagem" - não é, de forma alguma, o objetivo principal da lei. Para Isabel Sánchez García de Paz, a definição de crime organizado na Espanha não é nada além de uma "definição instrumental”. (Isabel Sánchez García de Paz, La criminalidad organizada..., ob. cit, p. 31). 
radioativo; delitos contra a saúde pública; falsificação de moeda; tráfico e depósito de armas, munições ou explosivos; terrorismo; delitos relacionados à propriedade industrial; e delitos contra o patrimônio histórico ${ }^{118}$. $^{119}$

\subsection{Tipificação dada pela lei brasileira.}

Há quase duas décadas, a legislação brasileira vem tentando encontrar uma solução para o problema do combate à criminalidade organizada. Diversos foram os projetos - alguns convertidos em leis - que tentaram tipificar o fenômeno, enfileirando armas investigativas e processuais para a sua investigação. Via de regra, podem ser apontadas três linhas doutrinárias e legislativas normalmente empregadas para sua a definição. A primeira consiste em partir da noção de organização criminosa para definir o crime organizado, o qual seria, assim, a atividade ilícita praticada pelos membros integrantes daquela organização. A segunda trata de definir o crime organizado com base em suas características essenciais, sem, no entanto, especificar quais os tipos penais cuja prática configuraria o crime organizado. A terceira e última, por sua vez, consiste em especificar um rol de crimes como sendo crimes $\operatorname{organizados}^{120} \cdot{ }^{121}$

\subsubsection{O Projeto de Lei n. 3.516, de 1989 (“'Projeto Miro Teixeira”).}

O primeiro Projeto de Lei relacionado ao tema elaborado no

\footnotetext{
${ }^{118}$ Sílvia Planet Robles, Políticas de seguridad... ob. cit., p. 171.

${ }^{119}$ Note-se que o delito de "pertencer a uma associação ilícita" é independente dos delitos que a associação ilícita possa vir a cometer. Por isso, a doutrina e jurisprudência dominante entendem que se forma um concurso de delitos entre o crime de participação na associação ilícita e o crime que tenha sido por esta cometido. Excepciona-se, aqui, aqueles tipos penais que já apresentam, em sua redação, figura especial (pena agravada) para quando tiver sido cometida por algum tipo de associação criminosa, como é o caso dos delitos de terrorismo, que serão analisados a seguir.

${ }^{120}$ Essa foi a técnica empregada, por exemplo, na elaboração da Lei de Crimes Hediondos (Lei 8.072/1990).

${ }^{121}$ Antonio Scarance Fernandes, $O$ equilíbrio..., ob. cit., p. 241.
} 
país foi o Projeto de Lei n. 3.516, de 1989 ("Projeto Miro Teixeira”), elaborado por uma subcomissão presidida pelo Deputado Miro Teixeira, que tinha como relator o Deputado Michel Temer, criada no âmbito da Comissão de Constituição e justiça e Redação.

O documento tratava da criminalidade organizada e das formas de combatê-la, seguindo, para isso a primeira das linhas apontadas acima - a definição de crime organizado a partir da noção de organização criminosa, ou seja, a partir de seus elementos essenciais. ${ }^{122}$ Dessa forma, o Projeto de Lei definia, primeiramente, em seu artigo $2^{\circ}$, o que seria organização criminosa ("aquela que, por suas características, demonstre a existência de estrutura criminal, operando de forma sistematizada, com atuação regional, nacional elou internacional" ${ }^{123}$ ), para só então conceituar o crime organizado e a sua prática, com base naquela definição primária. ${ }^{124}$

Dessa forma, pode-se afirmar que o referido documento lançou um modelo - ainda que simplista ${ }^{125}$ - de conceituação do crime organizado pelo nosso ordenamento jurídico. É justo dizer que foi o mais interessante dos modelos de conceituação de crime organizado até hoje já sugeridos pelo legislador em nosso ordenamento jurídico. No entanto, tal linha não floresceu. Já no Projeto de Lei n. 62, enviado à Câmara, a definição de crime organizado foi alterada da seguinte forma: "considera-se crime organizado aquele que de algum modo coopera com os fins ou participa das atividades das quadrilhas, bandos ou organizações previstas pelo artigo

${ }^{122}$ Antonio Scarance Fernandes, $O$ equilíbrio..., ob. cit., p. 241

${ }^{123}$ Antonio Scarance Fernandes, O equilíbrio..., ob. cit., p. 241.

${ }^{124}$ Além disso, o Projeto Miro Teixeira lançava, como meios excepcionais de investigação de provas nas ações do crime organizado, a infiltração policial; as ações controladas; o acesso a documentos e informações fiscais, bancárias, financeiras e eleitorais; e o impedimento, a interrupção, a interceptação, a escuta e a gravação das comunicações telefônicas, conforme regulado em lei especial $\left(\operatorname{artigo~} 2^{\circ}\right.$ ). Todas estas medidas, no entanto, dependeriam de prévia autorização judicial, e de ciência posterior do Ministério Público (artigo $3^{\circ}$, parágrafo único).

${ }^{125}$ Antônio Sérgio Altieri de Moraes Pitombo critica a conceituação de crime organizado oferecida pelo Projeto de Lei em questão: "Percebe-se, desde logo, que definição não havia. Faltou indicar características específicas que mostrassem a particularidade da organização criminosa. Fica clara, assim, a ausência da fixação de limites, bem como o descuido na descrição do que seria a essência do fenômeno associativo. Além disso, adota-se o lugar da ocorrência do fato - regional, nacional ou internacional - como algo relevante, o que não corresponde aos aspectos estritamente necessários para a definição. Sem esquecer de que a palavra 'estrutura' apresenta muitos significados e não confere precisão à norma jurídica no sentido como veio a ser empregada. A solução dada pelos juristas não tipificada como crime a organização criminosa, tão-só considerava que a persecução penal deveria se voltar para a apuração de 'crime decorrente de organização criminosa' (art. $1^{o}$ do Projeto de Lei 3.516/1989). Portanto, o foco de interesse não estava na associação para a prática de crime, mas nas infrações penais perpetradas de forma coletiva”. (Antônio Sérgio Altieri de Moraes Pitombo, Organização criminosa - nova perspectiva do tipo legal. São Paulo: Revista dos Tribunais, 2009, p. 90. 
288 do Código Penal" (artigo $\left.2^{\circ}\right) .{ }^{126}$ Uma vez aprovado pela Câmara, por sua vez, o Projeto ficou longo tempo em tramitação no Senado, onde foi substituído, sofrendo uma transformação radical. ${ }^{127}$ A redação dada ao aludido Projeto para seu substitutivo no Senado, de 1990, assim estabelecia: “Art. $2^{\circ}$. Considera-se crime organizado o conjunto dos atos delituosos que decorram ou resultem das atividades de quadrilha ou bando, definidos no par. $1^{o}$ do art. 288 do Decreto-lei $n$. 2.848, de 7 de dezembro de 1940 - Código Penal”. ${ }^{128}$ Este novo Projeto, então, já totalmente modificado e substituído, é que deu origem à Lei n. 9.034/95.

Ou seja: já ao ser enviado para discussão nas Casas Legislativas, o Projeto em questão já se encontrava seriamente deturpado e desprovido de suas elogiosas características originais; e o modelo por ele lançado não foi seguido pelo nosso legislador ao promulgar a Lei ${ }^{\circ} 9.034 / 95$.

\subsubsection{A Lei n. 9.034 , de 1995 .}

Em 03 de maio de 1995 - sob clima de insegurança da população, a qual exigia uma resposta imediata do Governo para a questão da crescente violência no país ${ }^{129}$; e frente à conveniência do discurso de combate ao crime

\footnotetext{
${ }^{126}$ Sérgio Marcos de Moraes Pitombo, Crime organizado, ob. cit..

127 Antonio Scarance Fernandes, Crime organizado e legislação brasileira. In: Justiça Penal 3: críticas e sugestões. O crime organizado (Itália e Brasil). A modernização da lei penal. Coord.: Jaques de Camargo Penteado. São Paulo: Revista dos Tribunais, 1995, p. 35.

${ }^{128}$ Sérgio Marcos de Moraes Pitombo, Crime organizado, ob. cit.

${ }^{129}$ Segundo a mais abalizada doutrina, a edição da Lei n. 9.034/95 pode ser considerada um exemplo do chamado "direito penal de emergência", no qual normas jurídicas emergenciais são criadas pelo Estado, às pressas, como tentativa de prestar uma resposta rápida aos anseios da coletividade, conforme ensina Renata Almeida da Costa: "Em função da urgência dos acontecimentos sociais, o Estado edita normas jurídicas que violam garantias e direitos individuais. Ou melhor, no afã de adaptar o direito à sociedade globalizada economicamente e integrada supranacionalmente, acaba por tornar direitos individuais globalizados $e$ supranacionais, violando as garantias individuais e os princípios gerais de direito”. (Renata Almeida da Costa, A sociedade complexa..., ob. cit., p. 90). Ainda, conforme Antônio Sérgio Altieri de Moraes Pitombo, "cuida-se de estratégia, de alguns governos, voltada a convencer a sociedade da ameaça das organizações criminosas e da pretensa eficácia real de disposições legais, incompatíveis com a normativa constitucional e com a tutela dos direitos individuais, porém criadas para produzir a impressão tranqüilizadora de um legislador atento”. (Antônio Sérgio Altieri de Moraes Pitombo, Organização criminosa..., ob. cit., p. 115). Assim, a lei em questão seria o resultado de um processo de criminalização crescente, iniciado na década de 1980; e fruto de uma tentativa de resposta do Estado às exigências sociais por uma solução imediata para o problema da criminalidade crescente. Ela representa, dessa forma, um "verniz" destinado a apaziguar os
} 
ânimos da coletividade - a qual, deparada com as notícias veiculadas pela mídia, que só fazem exaltar a violência e a criminalidade, clama ao poder público por soluções rápidas, e que venham, de preferência, do âmbito do Direito Penal. (Renata Almeida da Costa, A sociedade complexa..., ob. cit., p. 90). No entanto, há que se atentar para o fato de que tais soluções "emergenciais" - a despeito de aumentarem o rigor das sanções, introduzirem novos tipos de associação criminosa, automatizarem as prisões cautelares, e endurecerem a execução das penas (Sergio Moccia, La perenne..., ob. cit., p. 53) - são, via de regra, pouco eficazes - tal como ocorre com a Lei n. 9.034/95, ora em análise. Luiz Carlos Rodrigues Duarte afirma que tal modo de agir estatal só faz agredir ainda mais a sociedade - já tão sensibilizada com a criminalidade -, com as próprias atuações ineficazes do Estado, que vende uma "ilusão" de eficiência para os cidadãos, sem, no entanto, conseguir resolver o problema. O autor assim descreve o "agir artificial" do Estado: "incompetente e inoperante para evitar ou punir o crime organizado, ilude a sociedade com soluções enganosas que ardilosamente cria no afã de gerar uma imagem de eficiência funcional da persecutio desses criminosos. E a mídia em geral acoberta e colabora com toda essa hipocrisia oficial." (Luiz Carlos Rodrigues Duarte, Princípio vitimológico..., ob. cit., p. 33). No mesmo sentido, a crítica feita por René Ariel Dotti: "Pregar o endurecimento de leis penais para combater o mal crônico da criminalidade organizada é iludir o povo com a 'cortina de fumaça' que de tempos em tempos se abre para atenuar os sentimentos de angústia e anomia”. (René Ariel Dotti, A falácia das novas leis penais contra o crime organizado (I). Migalhas, 23 de janeiro de 2007. Disponível no endereço eletrônico: http://www.migalhas.com.br/mostra_noticia_articuladas.aspx?cod=34600, acessado em 19 de novembro de 2009). No mesmo sentido, aduz Eugenio Raúl Zaffaroni: “las leyes penales son uno de los medios preferidos del estado espetáculo y de sus operadores 'showmen', em razón de que son baratas, de propaganda fácil y la oponión se engaña com suficiente frecuencia sobre su eficacia. Se trata de un recurso que otorga alto redito político com bajo costo”. (Eugenio Raúl Zaffaroni, Globalización y sistema penal en America Latina: de la seguridade nacional a la urbana. A legislação brasileira em face do crime organizado. Revista Brasileira de Ciências Criminais. São Paulo: Revista dos Tribunais, v. 5, n. 20, out.-dez./1997, p. 17). André Luis Callegari e Maiquel Ângelo Dezordi Wermuth também fazem uma dura crítica ao uso político do Direito Penal: "o Direito Penal vê-se, assim, transformado em um instrumento que passa a ser utilizado politicamente para a busca de fins que não lhe são próprios em um Estado Democrático de Direito. Quando manejado no sentido de dar respostas 'eficazes' às novas formas de criminalidade, assume um caráter meramente simbólico, dado que proporcional resultados político-eleitorais imediatos a partir da criação, no imaginário popular, da impressão tranqüilizadora da existência de um legislador atento à realidade social. (...) A utilização política do Direito Penal simbólico se deve ao fato de que, com ela, o legislador adquire uma 'boa imagem' em face da sociedade, na medida em que, a partir das decisões político-criminais irracionais, atende às demandas sociais, obtendo, assim, reflexamente, um grande número de votos. Não obstante isso, a utilização do Direito Penal simbólico representa a alternativa mais 'barata' na hora de articular soluções para problemas sociais, visto que as medidas e programas sociais sempre são mais custosos do ponto de vista finenceiro". (André Luis Callegari e Maiquel Ângelo Dezordi Wermuth, Crime organizado: conceito e possibilidade de tipificação diante do contexto de expansão do direito. Revista Brasileira de Ciências Criminais. São Paulo: Revista dos Tribunais, n. 79, ano 17, jul.-ago./2009, pp. 12-13). Frederico Figueiredo, por sua vez, considera a política criminal atual, responsável pela aprovação da Lei em questão, populista e irracional, estando nela presentes todas as conhecidas técnicas populistas em matéria penal, quais sejam: "o apelo aos medos e inseguranças coletivos; o apelo à moralidade; a apresentação da sociedade numa imagem dicotômica e simplificadora; e a falta de um programa coerente e abrangente". (Frederico Figueiredo, Política criminal populista: para uma crítica do direito penal instrumental. Revista Brasileira de Ciências Criminais. São Paulo: Revista dos Tribunais, ano 16, n. 70, jan.-fev./2008, pp. 105106). Winfried Hassemer segue na mesma linha, entendendo que o medo e a insegurança sentidos pela população são manipulados pelo governo para justificar o emprego de métodos especiais no combate à criminalidade organizada: "A manipulação do medo coletivo difuso resultante da criminalidade de massas, praticada com o escopo de obter meios e instrumentos de combate à criminalidade violenta mediante a restrição das liberdades, constitui uma conhecida tática de Política criminal populista, que não traz resposta aos problemas diários das pessoas frente à criminalidade de massas.". (Winfried Hassemer, Segurança pública..., ob. cit., p. 58). Note-se o autor destaca que não é a ameaça real da criminalidade e da violência que constitui o fator determinante para a política de segurança pública, e sim a percepção de tal ameaça pela coletividade. Prova disso é que há mais medo do crime nas camadas sociais em que há menor probabilidade de ele ocorrer, e vice-versa. Assim sendo, segundo o autor, uma boa política de segurança pública deveria levar em conta não apenas as causas da criminalidade e da violência, como os múltiplos fatores de sua percepção social. (Winfried Hassemer, Segurança pública..., ob. cit., pp. 63-64). 
organizado $^{130}$ - foi promulgada a Lei n. 9.034, a primeira no Brasil a efetivamente regulamentar - ao menos em teoria - os meios utilizados para o combate à criminalidade organizada. Tal lei encontra-se vigente até hoje, muito embora tenha sido posteriormente alterada pela Lei n. 10.217, de 11 de abril de 2001.

O artigo $1^{\circ}$ da Lei n. 9.034/1995, em sua redação original, encontra-se assim redigido:

“Art. 1". Esta lei define e regula meios de prova e procedimentos investigatórios que versarem sobre crime resultante de ações de quadrilha ou bando". 131

Inexistindo, em todo o corpo da Lei, qualquer outra definição do que seria crime organizado - muito embora o texto legal empregue várias vezes a expressão "organização criminosa"132 -, é forçoso depreender-se, da redação do artigo $1^{\circ}$, que a lei considera crime organizado como toda e qualquer ação de quadrilha ou bando. Seriam, portanto, expressões sinônimas.

Como se vê, o legislador aproveitou a estrutura de um tipo convencional - o delito de quadrilha ou bando, tipificado no artigo 288 do Código Penal ${ }^{133}$ - e definiu nova modalidade criminosa, com linguagem bastante abrangente e confusa. ${ }^{134}$ No entanto, é imprescindível que se compreenda que o conceito de crime organizado é amplo, não se situando exclusivamente no âmbito das atividades das quadrilhas e dos bandos. ${ }^{135}$ Conforme observa Antônio Sérgio Altieri de Moraes Pitombo, "quadrilha ou bando e crime organizado apresentariam mais diferenças do que semelhanças, sendo inaceitável a transposição do art. 288 do CP para tipificar a estrutura complexa e perene da organização criminosa. O grupo de pessoas, unidas de forma rudimentar, apto a tipificar a quadrilha não se coadunaria com o modelo empresarial da organização

\footnotetext{
${ }^{130}$ Antônio Sérgio Altieri de Moraes Pitombo, Organização criminosa..., ob. cit., p. 102.

${ }^{131}$ Letra da lei.

${ }^{132}$ Antonio Scarance Fernandes, Crime organizado e legislação..., ob. cit., p. 35.

133 “Art. 288. Associarem-se mais de três pessoas, em quadrilha ou bando, para o fim de cometer crimes:

Pena-reclusão, de 1 (um) a 3 (três) anos”.

${ }^{134}$ Alberto Silva Franco, Um difícil processo..., ob. cit.

${ }^{135}$ Carlos Eduardo de Athayde Buono e Antonio Tomás Bentivoglio, O crime organizado. Boletim IBCCrim, São Paulo, n. 21, setembro/1994.
} 
criminosa. Entre ambas as figuras delitivas, haveria proximidade, tão-só, por configurarem espécies de associação criminosa”. ${ }^{136}$

Retomando o raciocínio de Hassemer ${ }^{137}$, já apresentado supra, não se pode elaborar um conceito jurídico-penal de crime organizado, ou de organização criminosa, sem que se traga ao conceito algo de novo - algo diferente daquilo já conhecido e presente no ordenamento jurídico comum -, até mesmo para justificar e tornar úteis os meios excepcionais que são postos à disposição para o seu combate. ${ }^{138}$ Conforme enfatiza o autor, não se pode, jamais, confundir a criminalidade comum - na qual estão inseridas os crimes de quadrilha ou bando - com a criminalidade organizada, sob pena da ineficácia da política de segurança empregada, uma vez que os meios adequados ao combate a uma ou a outra mostram-se completamente diversos ${ }^{139} \cdot{ }^{140}$

No entanto, o que se observa, in casu, é que o legislador penal falhou em sua tarefa de edição da lei e de criação do tipo penal relacionado à criminalidade organizada, demonstrando desconhecimento da matéria versada, bem como da técnica de composição das figuras típicas. ${ }^{141}$ Primeiramente, por acessar o fenômeno extremamente complexo da criminalidade organizada de maneira ostensivamente simplista - e, por isso mesmo, de nenhuma valia - em seu processo de tipificação. ${ }^{142} \mathrm{E}$, em seguida, por resumir a área de significado do conceito de crime organizado a um dos tipos constantes da Parte Especial do Código Penal. ${ }^{143}$ Conforme sustenta Alberto Silva Franco, “cuida-se de matéria intrincada, de difícil caracterização e de pouca transparência. Bem por isso, conformar-se melhor no âmbito de uma lei penal especial, que pode, sem dificuldades em nível de tramitação legislativas, aumentar o sei raio de incidência para

\footnotetext{
${ }^{136}$ Antônio Sérgio Atieri de Moraes Pitombo, Organização criminosa..., ob. cit., p. 112.

${ }^{137}$ Winfried Hassemer, Segurança pública..., ob. cit., p. 59.

${ }^{138}$ Winfried Hassemer, Segurança pública..., ob. cit., p. 59.

${ }^{139}$ Winfried Hassemer, Segurança pública..., ob. cit., p. 57.

${ }^{140}$ Para ilustrar a referida problemática, Geraldo Prado, William Douglas e Abel Fernandes Gomes oferecem a seguinte ilustração: “Não se concebe, por exemplo, que 'ladrões de galinha associados' sejam vistos, do ponto de vista processual, para fim de limitação de direitos com a ampliação de poderes probatórios e também de cassação da liberdade, de forma idêntica que aos grupos de fraudadores da Previdência ou aos responsáveis pela circulação ilícita internacional de entorpecentes". (Geraldo Prado, William Douglas e Abel Fernandes Gomes, Crime organizado..., ob. cit., p. 53).

${ }^{141}$ Alberto Silva Franco, Um difícil processo..., ob. cit.

${ }^{142}$ Alberto Silva Franco, Um difícil processo..., ob. cit.

${ }^{143}$ Alberto Silva Franco, Um difícil processo..., ob. cit.
} 
abarcar novas e inesperadas situações delituosas, do que no corpo de um diploma legal que busca tendencialmente um nivel maior de fixidade e de permanência." "144 $\mathrm{O}$ resultado é uma lei especial que fornece instrumentos legais para combater "um crime que, legalmente, não existe". ${ }^{145}$

De fato, a lei, ao furtar-se a seguir o caminho previamente traçado pelo Projeto de Lei n. 3.516, de 1989, não definiu organização criminosa, nem ao menos - através de seus elementos essenciais - o crime organizado. ${ }^{146}$ Não enumerou condutas que, praticadas pela organização criminosa, constituiriam formas de crimes organizados. Ao optar em deixar em aberto os tipos penais que configurariam tal delito, acabou por admitir que, potencialmente, qualquer crime - mesmo aqueles de menor potencial ofensivo - pudesse se caracterizar como tal, bastando que decorresse das ações de quadrilhas ou bandos ${ }^{147} \cdot 148$

Por outro lado, também no momento da colheita e da avaliação das provas do crime organizado - ou seja, da aplicação dos dispositivos excepcionais de investigação e de obtenção de elementos de prova, bem como da valoração das provas obtidas pelo juiz competente - a lei promulgada mostrou-se falha e, em última análise, inaplicável.

Primeiramente, quanto aos meios excepcionais de obtenção de elementos de prova em si, enumerados inicialmente no artigo $2^{\circ}$ da referida lei, é plausível anotar que o texto legislativo em questão parece abrigar uma concepção de pesquisa ilimitada da verdade, própria dos sistemas autoritários. ${ }^{149}$ Nesse sentido, a lei

\footnotetext{
${ }^{144}$ Alberto Silva Franco, Um difícil processo..., ob. cit.

${ }^{145}$ Guaracy Mingardi, O Estado e o crime organizado. São Paulo: Instituto Brasileiro de Ciências Criminais, 1998, p. 90.

${ }^{146}$ Antonio Scarance Fernandes, O conceito de crime organizado na Lei 9.034. Boletim IBCCrim, São Paulo, n. 31, julho/1995.

${ }^{147}$ Antonio Scarance Fernandes, $O$ conceito..., ob. cit.

${ }^{148}$ Ainda sobre a lacuna na conceituação de criminalidade organizada deixada pela lei em questão, Eduardo Araújo da Silva observou que o texto legal "não partiu de uma noção de organização criminosa, não definiu o crime organizado por seus elementos essenciais, não arrolou as condutas que constituiriam a criminalidade organizada nem procurou aglutinar essas orientações para delimitar a matéria. Optou tão-somente, num primeiro momento, por equiparar a organização criminosa às ações resultantes de quadrilha ou bando (art. $1^{\circ}$ )" (Eduardo Araújo da Silva, Crime Organizado..., ob. cit., p. 37).

${ }^{149}$ Antonio Magalhães Gomes Filho, Também em matéria processual provoca inquietação a Lei Anti-Crime Organizado. Boletim IBCCrim, São Paulo, n. 13, fev. 1994.
} 
autoriza, no inciso II $^{150}$ do referido artigo, a ação controlada ${ }^{151}$, medida de legitimidade ética e jurídica bastante contestada, e que deve ser longamente discutida, com a ponderação de sacrifícios e resultados, antes de ser adotada ${ }^{152} \cdot{ }^{153}$ Ainda, no inciso III $^{154}$ do mesmo artigo, fica autorizada a violação do sigilo das comunicações telefônicas - sem que, no entanto, seja disciplinada a forma como serão realizadas tais operações, conforme exigido pelo artigo $5^{\circ}$, XII, da Constituição Federal ${ }^{155} \cdot{ }^{156}$

As regras delineadas no texto legal referentes à autorização judicial para a realização dos referidos meios de obtenção de prova são igualmente

150 "II - a ação controlada, que consiste em retardar a interdição policial do que se supõe ação praticada por organizações criminosas ou a ela vinculado, desde que mantida sob observação e acompanhamento para que a medida legal se concretize no momento mais eficaz do ponto de vista da formação de provas $e$ fornecimento de informações".

151 A chamada "ação controlada" é prática que "possibilita aos agentes policiais retardarem suas intervenções em relação a infrações em curso, praticadas por organizações criminosas, para acompanhar os atos de seus membros até o momento mais apropriado para a obtenção da prova e efetuar suas prisões" (Eduardo Araújo da Silva, Crime Organizado..., ob. cit., p. 93). De se ressaltar, no entanto, que a atividade do policial em relação delito em curso, enquanto não efetua sua intervenção, é de mera observação e acompanhamento, não podendo se confundir, em momento algum, com o estímulo ao cometimento de infrações penais. (Geraldo Prado, William Douglas e Abel Fernandes Gomes, Crime organizado e suas conexões com o poder público, comentários à Lei $n^{\circ} 9.034 / 95$, considerações críticas. Rio de Janeiro: Impetus, 2000).

${ }^{152} \mathrm{O}$ referido artigo previa, também, originalmente, em seu inciso I, a figura do agente infiltrado - objeto deste trabalho, que será discutida de maneira mais aprofundada mais à frente, no Capítulo 3. No entanto, tal inciso foi objeto de veto por parte do então Presidente da República, Fernando Henrique Cardoso, sob o argumento de que contrariaria o interesse público, uma vez que permitiria que o agente policial, independentemente de autorização do Poder Judiciário, se infiltrasse em quadrilhas ou bandos para a investigação do crime organizado. Estaria, assim, aos olhos do Poder Executivo, concedida expressa autorização legal para que o agente infiltrado cometa crimes, ficando preexcluída a antijuridicidade, o que afrontaria os princípios adotados pela sistemática do Código Penal. A mensagem de veto do Presidente da República - baseada em um parecer fornecido pelo Ministério da Justiça - sustenta ainda que a redação final do inciso em questão difere da original do Projeto, que havia, esta sim, sido baseada em largos estudos elaborados pela sucomissão presidida pelo Deputado Miro Teixeira, e que condicionava, de forma mais apropriada, a infiltração de agentes de polícia em organizações criminosas à autorização judicial. (Mensagem de Veto n. 483, à Lei n. 9.034/95, disponível no endereço eletrônico http://www.planalto.gov.br/CCIVIL/Leis/L9034.htm, acessado em 13 de novembro de 2008).

153 Antonio Magalhães Gomes Filho, Também em matéria processual..., ob. cit.

154 “III - o acesso a dados, documentos e informações fiscais, bancárias, financeiras e eleitorais”.

155 “Art. $5^{\circ}$ Todos são iguais perante a lei, sem distinção de qualquer natureza, garantindo-se aos brasileiros $e$ aos estrangeiros residentes no País a inviolabilidade do direito à vida, à liberdade, à igualdade, à segurança e à propriedade, nos termos seguintes:

(...)

XII - é inviolável o sigilo da correspondência e das comunicações telegráficas, de dados e das comunicações telefônicas, salvo, no último caso, por ordem judicial, nas hipóteses e na forma que a lei estabelecer para fins de investigação criminal ou instrução processual penal”.

${ }^{156}$ Antonio Magalhães Gomes Filho, Também em matéria processual..., ob. cit. 
impróprias. Não existe no corpo da lei a obrigatoriedade de fundamentação das decisões ${ }^{157}$ que autorizam ou negam a utilização daqueles instrumentos, o que contraria preceito constitucional disposto no artigo 93, IX ${ }^{158}$, de nossa Constituição da República. ${ }^{159}$

Além disso, o artigo $3^{\circ}$ da referida $1 \mathrm{i}^{160}$, que atribui ao próprio juiz - o mesmo que, mais à frente no procedimento, julgará a questão - a faculdade de realizar diligências que visam à colheita de provas ${ }^{161}$, revestindo, ainda, de sigilo o resultado de tais diligências, a pretexto de resguardar a intimidade das partes. ${ }^{162}$ Tais disposições, ao resgatarem a figura do juiz-inquisidor ${ }^{163}$ - tão característica do já ultrapassado modelo inquisitório de processo penal -, vulneram o modelo acusatório, de

${ }^{157}$ No sistema de vigente de livre convencimento do juiz, a necessidade de fundamentação (ou motivação)
das decisões proferidas pelo Magistrado competente é inquestionável, tendo ganhado contornos de garantia
das partes no processo. Tal se baseia em três pontos básicos, a saber: i) garante a atuação equilibrada e
imparcial do juiz, vez que apenas pela motivação será possível verificar se ele de fato agiu com a devida
imparcialidade; ii) controla a legalidade das decisões judiciárias, uma vez que a aferição das razões
constantes da sentença será possível saber se esta deriva da lei ou do arbítrio do julgador; e iii) funciona
como garantia das partes, pois permite que elas possam verificar se o magistrado levou em consideração, ao
julgar, todos os argumentos e provas por aquelas produzidos. (Antonio Magalhães Gomes Filho, Antonio
Scarance Fernandes e Ada Pellegrini Grinover, As nulidades no processo penal. São Paulo: Revista dos
Tribunais, 2004, pp. 254-255).Dessa forma, tem-se que “abandonados os sistemas de prova legal e da íntima
convicção do juiz, tem o magistrado liberdade na seleção e valoração dos elementos de prova para proferir
a decisão, mas deve, obrigatoriamente, justificar o seu pronunciamento”. (Antonio Magalhães Gomes Filho,
Antonio Scarance Fernandes e Ada Pellegrini Grinover, As nulidades..., ob. cit., p. 254). Para mais sobre a
garantia da motivação das decisões no processo penal, ver: Antonio Magalhães Gomes Filho, A motivação
das decisões penais. São Paulo: Revista dos Tribunais, 2001. 158 “Art. 93. Lei complementar, de iniciativa do Supremo Tribunal Federal, disporá sobre o Estatuto da Magistratura, observados os seguintes princípios:

(...)

IX todos os julgamentos dos órgãos do Poder Judiciário serão públicos, e fundamentadas todas as decisões, sob pena de nulidade, podendo a lei limitar a presença, em determinados atos, às próprias partes e a seus advogados, ou somente a estes, em casos nos quais a preservação do direito à intimidade do interessado no sigilo não prejudique o interesse público à informação”.

${ }^{159}$ Antonio Magalhães Gomes Filho, Também em matéria processual..., ob. cit.

160 “Art. $3^{\circ}$ Nas hipóteses do inciso III do art. $2^{o}$ desta lei, ocorrendo possibilidade de violação de sigilo preservado pela Constituição ou por lei, a diligência será realizada pessoalmente pelo juiz, adotado o mais rigoroso segredo de justiça”.

161 A esse respeito, escreveu Luiz Carlos Betanho: "Veja-se a determinação de colheita pessoal de provas pelo juiz. Sabendo-se que um perito que fosse nomeado pelo Juiz prestaria compromisso de servir lealmente à Justiça, o que deveria ter qualificação técnica adequada, não se compreende porque a busca de dados fiscais, bancários, etc., deva ser feita pelo Juiz em pessoa. Seria suficiente uma autorização judicial, pois o conhecimento das informações sigilosas por um certo número de pessoas é inevitável e a própria lei especial o prevê ao permitir que o Juiz requisite o auxílio de pessoas que tenham ou possam ter acesso aos objetos do sigilo. Acaba tudo na mesma, pois um perito atuaria de forma mais efetiva, sem retirar o Juiz de suas atribuições normais e sem transformá-lo em investigador de polícia ou perito desinformado”. (Luiz Carlos Betanho, O cone do silêncio à brasileira. Boletim IBCCrim, São Paulo, n. 30, junho/1995).

${ }^{162}$ Ada Pellegrini Grinover, Que juiz inqusidor é esse? Boletim IBCCrim, São Paulo, n. 30, junho/1995.

${ }^{163}$ Ada Pellegrini Grinover, Que juiz inqusidor..., ob. cit. 
processo de partes ${ }^{164}$, instituído pela Constituição da República de $1998^{165} \cdot{ }^{166}$ Além disso, comprometem a imparcialidade do juiz ${ }^{167}$ e o princípio da publicidade, bem como - uma vez que, para manter o referido sigilo, a sentença deverá ter "fundamento secreto"168 -, novamente, o dever de fundamentação das decisões, dois dos mais importantes postulados do devido processo legal

\subsubsection{A Lei n. 10.217, de 11 de abril de 2001 .}

Em 11 de abril de 2001, foi editada a Lei n. 10.217, que alterou a Lei n. 9.034/95. Em seu artigo $1^{\circ}$, foi introduzida a expressão "organizações ou associações de qualquer tipo"169, perturbando ainda mais o significado de "crime organizado". ${ }^{170}$ Assim, a nova redação do referido artigo passa a dispor:

"Art. 1". Esta lei define e regula os meios de prova $e$ procedimentos investigatórios que versem sobre ilícitos decorrentes de ações praticadas por quadrilha ou bando ou organizações ou associações criminosas de qualquer natureza”.

\footnotetext{
${ }^{164} \mathrm{O}$ processo acusatório deve ser entendido como aquele em que as funções de acusar, defender e julgar são distintas, atribuídas a órgãos diversos, permitindo-se, assim, que todo o processo se desenvolva em contraditório pleno e de forma pública. (Ada Pellegrini Grinover, A legislação brasileira em face do crime organizado. Revista Brasileira de Ciências Criminais, São Paulo, ano 5, n. 20, out.-dez./1997, p. 59).

${ }^{165}$ Em sentido contrário, Sérgio Marcos de Moraes Pitombo: "O próprio juiz, então, realizar a diligência de busca e de apreensão não deve causar estranheza. Com efeito: 'Quando a própria autorizade policial ou judiciária não a realizar pessoalmente, a busca domiciliar deverá ser precedida da expedição de mandado.' (art. 241, do Cód. De Proc. Penal). Nunca se divisou inconstitucionalidade em tal norma. A evidência de o Juiz ultimar a apreensão não o torna parcial; na mesma medida em que, ao colher ou produzir prova, só por isso, jamais se fez suspeito. A inquisitividade do juiz penal, de outra sorte, nada tem a ver com a desfunção do denominado modelo acusatório. Não tem mais lugar a confusão entre processo inquisitivo e inquisitoriedade judicial". (Sérgio Marcos de Moraes Pitombo, Crime organizado, ob. cit.)

${ }^{166}$ Ada Pellegrini Grinover, Que juiz inqusidor..., ob. cit.

167 Ada Pellegrini Grinover, Que juiz inqusidor..., ob. cit. Neste artigo, a autora chega a defender a inconstitucionalidade do artigo em questão, pelos motivos expostos supra.

${ }^{168}$ Luiz Carlos Betanho, O cone do silêncio..., ob. cit.

${ }^{169}$ Eduardo Araújo da Silva, Crime organizado..., ob. cit., p. 38.

${ }^{170}$ Antônio Sérgio Altieri de Moraes Pitombo, Organização criminosa..., ob. cit., p. 106.
} 
É bastante claro que a nova lei não se mostrou suficiente para solucionar o problema conceitual do crime organizado no direito brasileiro ${ }^{171}$, vez que permanece silente quanto à definição do fenômeno. ${ }^{172}$ A nova lei tem, é verdade, o mérito de distinguir, pela maneira como redige seu artigo $1^{\circ}$, os delitos de quadrilha ou bando de associação ou organização criminosa - pois são estes, de fato, institutos diversos ${ }^{173}$-; porém determinou que se aplicassem todos os dispositivos da Lei 9.034/05 também aos delitos de quadrilha ou bando, de forma que nivelou o tratamento destes crimes ao dispensado, em princípio, à organização ou associação criminosa. ${ }^{174}$ Assim, não teve a nova lei o condão de operar uma alteração significativa em relação à problemática inicial da ausência de definição do crime organizado no ordenamento jurídico brasileiro. ${ }^{175}$ Pelo contrário: verifica-se que a figura da "organização criminosa" e seus "sinônimos" aparecem no ordenamento jurídico sem qualquer critério, não existindo preocupação alguma com a coerência com o disposto na própria Lei n. 9.034/95. ${ }^{176}$ Conforme afirma Eduardo Araújo da Silva: “desperdiçou-se, em suma, a possibilidade de enfrentar uma das questões mais angustiantes do Direito Penal moderno: conceituar ou ao menos aproximar-se de um conceito de crime

${ }^{171}$ Eduardo Araújo da Silva, Crime organizado..., ob. cit., p. 38.

${ }^{172}$ De acordo com Rafael Pacheco, um ponto positivo da Lei n. 10.217/01 reside no fato de ter ela substituído a palavra "crimes" da lei anterior pelo vocábulo "ilícitos". Dessa forma, pode-se incluir as contravenções penais - como, por exemplo, o "jogo do bicho", jogo de azar que, sabidamente, configura a primeira modalidade de crime organizado existente em nosso país - no conceito de criminalidade organizada. (Rafael Pacheco, Crime organizado..., ob. cit., p. 50).

${ }^{173}$ Conforme assevera Antônio Sérgio Altieri de Moraes Pitombo, “ninguém mais podia negar o fato de a nova redação evidenciar se estar à frente de duas formas de associação criminosa, cada uma com dados elementares diferentes que não se confundiam no juízo de tipicidade penal". (Antônio Sérgio Altieri de Moraes Pitombo, Organização criminosa..., ob. cit., pp. 112-113).

${ }^{174}$ Antonio Scarance Fernandes, O equilíbrio..., ob. cit., p. 242.

${ }^{175}$ Em sentido contrário, Luiz Flávio Gomes defende que a edição da Lei $n^{\circ} 10.217 / 01$ implicou grande alteração no tratamento do crime organizado, uma vez que teria acarretado perda de eficácia de quase todo o conteúdo da Lei $\mathrm{n}^{\circ}$ 9.034/95. Sustenta o autor que a Lei $9.034 / 95$ possibilitava uma interpretação através da qual aceitava-se que o legislador havia dado o mínimo necessário de informação para que pudesse ser definido o conceito de "organização criminosa" sem que fosse violado o princípio da legalidade. No entanto, a Lei $n^{\circ} 10.217 / 01$ - que, por ser posterior e tratar do mesmo assunto, derroga a lei $n^{\circ} 9.034 / 95$, não mais permitiria tal interpretação, limitando-se a enunciar o delito, sem fornecer qualquer informação sobre seu conteúdo, - deixando, portanto, o tipo penal completamente aberto. Dessa forma, restaria violado o princípio da legalidade. Note-se, aqui, que, para o referido autor, não seria mais possível uma interpretação que entenda que as regras dos delitos de quadrilha ou bando configurem as características da organização criminosa. A esse respeito, ver: Luiz Flávio Gomes e Raúl Cervini, Crime organizado: enfoques criminológico, jurídico (Lei 9.034/95) e político-criminal. São Paulo: Revista dos Tribunais, 1997, pp. 103107; e Luiz Flávio Gomes, Crime organizado: o que se entende por isso depois da Lei $\mathrm{n}^{\circ} 10.217$, de 11.04.2001? - Apontamentos sobre a perda de eficácia de grande parte da Lei n ${ }^{\circ}$ 9.034/95. Revista Síntese de Direito Penal e Processual Penal. São Paulo, ano II, $\mathrm{n}^{\circ}$ 11, dez.-jan./2002.

${ }^{176}$ Antônio Sérgio Altieri de Moraes Pitombo, Organização criminosa..., ob. cit., p. 107. 
organizado ou de organização criminosa, para delimitar o âmbito de aplicação da Lei n. 9.034/95"177. ${ }^{178}$ No mesmo sentido, Antônio Sérgio Altieri de Moraes Pitombo: "Outra vez, perdia-se a oportunidade de se tipificar a organização criminosa, aumentando-se, entretanto, o problema da aplicação da Lei 9.034/1995, com o novo texto legal, que disciplinava algo, inexistente no direito penal pátrio, chamado agora de 'organizações ou associações criminosas de qualquer tipo". 179

Antonio Scarance Fernandes lembra, ainda, que, apesar de sua indefinição, faz-se referência à expressão "organização criminosa" em outros dispositivos desta mesma lei (artigos $4^{\circ}, 5^{\circ}$ e $6^{\text {ol180 }}$ ), e, ainda, em outras leis, nas quais dá azo a graves restrições de direitos individuais - como, por exemplo, na Lei de Execução Penal (Lei 7.210, de 1984), nas hipóteses de cabimento de Regime Disciplinar Diferenciado (art. 52, par. $2^{\circ}$, da referida $l \mathrm{ei}^{181}$ ). Ora, não se pode usar de medidas

${ }^{177}$ Eduardo Araújo da Silva, Crime organizado..., ob. cit., pp. 38-39.

178 Eduardo Araújo da Silva sustenta, ainda, que "ao limitar a definição de organização criminosa, o legislador equiparou o tratamento de quadrilhas que praticam pequenos ou médios crimes (furto e receptação de toca-fitas, roubo e receptação de relógios) a grandes organizações que se dedicam ao crime organizado (tráfico ilícito de substâncias entorpecentes e de armas, grandes fraudes fiscais), em frontal contradição com a tendência contemporânea de separar as diversas modalidades de crimes. Por outro lado, esse critério restringiu a aplicação do conceito de crime organizado em relação a determinados casos, nos quais os delitos praticados por pessoas desvinculadas de bandos ou quadrilhas possam configurar-se como 'crime organizado', comprometendo assim a punibilidade desses indivíduos”. (Eduardo Araújo da Silva, Crime organizado..., ob. cit., pp. 37 e 38). Por outro lado, Antonio Scarance Fernandes destaca que a redação da lei analisada prejudica também o direito de defesa do imputado: "Por outro lado, a imprecisão, no tocante à reserva legal, é perigosa para regular o exercício do direito de defesa. Caso se adotasse a orientação de ser a quadrilha ou bando um mínimo, cabendo ao Juiz, em cada processo, verificar a ocorrência do 'plus', sem nenhum parâmetro da lei, como saberia a autoridade policial quando agir? Como faria o Ministério Público para acusar por crime organizado? Em que momento o juiz afirmaria a existência de crime organizado?” (Antonio Scarance Fernandes, Crime organizado e legislação..., ob. cit., pp. 38-39).

${ }^{179}$ Antônio Sérgio Altieri de Moraes Pitombo, Organizações criminosas..., ob. cit., p. 100.

180 “Art. $4^{\circ}$ Os órgãos da polícia judiciária estruturarão setores e equipes de policiais especializados no combate à ação praticada por organizações criminosas.

Art. $5^{\circ}$ A identificação criminal de pessoas envolvidas com a ação praticada por organizações criminosas será realizada independentemente da identificação civil.

Art. $6^{\circ}$ Nos crimes praticados em organização criminosa, a pena será reduzida de um a dois terços, quando a colaboração espontânea do agente levar ao esclarecimento de infrações penais e sua autoria”.

181 "Art. 52. A prática de fato previsto como crime doloso constitui falta grave e, quando ocasione subversão da ordem ou disciplina internas, sujeita o preso provisório, ou condenado, sem prejuízo da sanção penal, ao regime disciplinar diferenciado, com as seguintes características:

(...)

$\S 2^{\underline{0}}$ Estará igualmente sujeito ao regime disciplinar diferenciado o preso provisório ou o condenado sob o qual recaiam fundadas suspeitas de envolvimento ou participação, a qualquer título, em organizações criminosas, quadrilha ou bando". 
excepcionais contra o indivíduo sem que se atenda, primeiro, ao pressuposto da legalidade ${ }^{182} \cdot{ }^{183}$

Além disso, a edição da nova lei perpetuou ainda outra dúvida já anteriormente existente: ao manter no texto legal a expressão quadrilha ou bando, leva a crer que toda e qualquer ação praticada por esse tipo de associação criminosa será considerada como crime organizado - contrariando, assim, a orientação de que os meios diferenciados de busca de provas deverão ser reservados apenas àquelas condutas consideradas excepcionalmente graves ${ }^{184} .185$

A nova lei modificou, ainda, o artigo $2^{\circ}$ da lei 9.034/95, incluindo nele os incisos IV, V e seu parágrafo único - os quais tratam, respectivamente, de dois novos meios extraordinários de investigação: da captação e interceptação ambiental e da infiltração de agentes policiais, bem como das condições para a autorização judicial para esta última -, sob a justificativa de que "entre as diversas medidas que têm sido adotadas em vários países no combate ao crime organizado, a infiltração controlada e a escuta ambiental vêm se destacando pelos resultados altamente positivos. Numerosas operações internacionais têm sido 182 Para o mesmo autor, a utilização de meios especiais de investigação de provas contra a criminalidade
organizada - bem como de meios de prova extraordinários ou atípicos em geral - apenas pode ser admitida se
for expressamente permitida pela legislação, numa clara manifestação do princípio da legalidade. Assim, em
tais casos, “a lei deve: a) regular e explicitar claramente a medida excepcional de obtenção ou produção de
prova, com os requisitos necessários para atuá-la; b) indicar o procedimento a ser seguido; e c) especificar
os órgãos, entidades ou pessoas legitimadas a requerê-la e a efetivá-la concretamente; d) indicar a
autoridade competente para autorizá-la e a motivação necessária na decisão a ser proferida. Em caso de
dúvida sobre algum desses aspectos, a interpretação da norma autorizadora da medida excepcional deve ser
restritiva, nunca ampliativa”. (Antonio Scarance Fernandes, O equilíbrio... ob. cit., p. 238).

${ }^{183}$ Antonio Scarance Fernandes, O equilíbrio..., ob. cit., pp. 242-243.

184 Tal orientação baseia-se no pensamento elaborado por Hassemer, o qual entende que os meios excepcionais de busca de provas são funcionais e efetivos apenas em relação à criminalidade organizada, não surtindo nenhum efeito em relação à criminalidade comum ou de massa (Winfried Hassemer, Segurança pública..., ob. cit., p. 55-56). Além disso, encontra suporte no chamado princípio da proporcionalidade, que se fundamenta na busca de um equilíbrio entre valores fundamentais conflitantes (Renata Almeida da Costa, A sociedade complexa..., ob. cit, p. 139), e de acordo com o qual, grosso modo, medidas que exigem sacrifícios de direitos - como é o caso dos meios excepcionais de busca de provas empregados no combate ao crime organizado - apenas devem ser empregados quando nenhum outro meio menos gravoso é capaz de obter aquele mesmo resultado, sendo aquele resultado absolutamente imprescindível. Além disso, não pode a restrição a direito individual ser admitida sem prévia lei, elaborada por órgão constitucional competente, imposta e interpretada de forma escrita; da mesma forma, a limitação só tem razão de ser se tiver como objetivo efetivar valores relevantes do sistema constitucional. (Antonio Scarance Fernandes, Processo penal constitucional. São Paulo: Revista dos Tribuinais, 2005, p. 56). Para mais sobre o princípio da proporcionalidade no processo penal, ver: Nicolas Gonzalez-Cuellar Serrano, Proporcionalidad y derechos fundamentales en el proceso penal. Madri: Colex, 1990.

${ }^{185}$ Eduardo Araújo da Silva, Crime organizado..., ob. cit., p. 39. 
realizadas com sucesso graças ao uso de informações obtidas por agentes infiltrados e mediante escutas ambientais". 186

No entanto, o que se tem, afinal, são duas leis editadas sobre a matéria "criminalidade organizada", desprovidas de qualquer tipo de sistematização ${ }^{187}$, e sem que se tenha, até o momento, conseguido atribuir-lhe uma definição jurídica. Isso porque, segundo Rafael Pacheco, "os legisladores brasileiros, diferentemente de seus pares em outras nações, optaram por não definir seus respectivos alcances, não instituir qualquer parâmetro limitador das expressões contidas no novo texto, tampouco as ações delituosas que pudessem ser objeto dessas leis". 188

\subsubsection{A Convenção de Palermo.}

No plano externo, inserido no esforço de cooperação internacional, o Brasil também tem aderido a tratados e convenções internacionais celebrados com o escopo de combater o crime organizado em termos globais. ${ }^{189}$ Tais tratados e convenções se constituem em mecanismos institucionais, concebidos no plano do Direito Internacional, com vistas ao enfrentamento da criminalidade organizada, sendo importantes fontes dos regramentos legais adotados em todos os países que a eles aderem inclusive no Brasil. ${ }^{190}$

Dentre tais mecanismos de Direito Internacional, se destaca a Convenção das Nações Unidas contra o Crime Organizado Transnacional - conhecida como Convenção de Palermo -, documento de amplo espectro e estrutura complexa, que busca combinar respostas ao problema criminal global que seja apropriadas a todos os

\footnotetext{
186 Art. $1^{\text {o }}$ do Projeto de Lei n. 3.725/2000 (Antônio Sérgio Altieri de Moraes Pitombo, Organização criminosa..., ob. cit., p. 97).

${ }^{187}$ Antônio Sérgio Altieri de Moraes Pitombo, Organização criminosa..., ob. cit., p. 157.

${ }^{188}$ Rafael Pacheco, Crime organizado..., ob. cit., p. 50.

${ }^{189}$ Rodrigo Carneiro Gomes, O crime organizado na visão da Convenção de Palermo. Belo Horizonte: Del Rey, 2009, p. 23.

${ }^{190}$ Rodrigo Carneiro Gomes, O crime organizado..., ob. cit., p. 23.
} 
Estados-membros, tendo em conta a diversidade de seus sistemas jurídicos. ${ }^{191}$ A Convenção foi incorporada ao ordenamento jurídico pátrio, com força de lei ordinária, pelo Decreto 5.015, de 12 de março de 2004.

As recomendações da referida Convenção se voltam especificamente ao combate do crime organizado ${ }^{192}$, sendo este documento, assim, "o documento normativo básico que, no plano internacional, rege as ações legais e as políticas institucionais de combate ao crime organizado praticadas na maioria dos países celebrantes desse Tratado Internacional. Com efeito, é a Convenção de Palermo que contém os postulados básicos, as diretrizes fundamentais que inspiram e orientam a elaboração de leis e a formulação das políticas de prevenção e repressão ao crime organizado, adotados pelos 147 países que a subscreveram, sob a égide das Nações Unidas". 193

A Convenção de Palermo toca num ponto importante - e especialmente sensível no ordenamento jurídico brasileiro - ao oferecer uma definição jurídica para o fenômeno do crime organizado, em seu artigo $2^{\circ}, a$ :

“Art. $2^{\circ} .(a)$. 'Organized criminal group' shall mean a structured group of three or more persons, existing for a period of time and acting in concert with the aim of committing one or more serious crimes or offences established in accordance with this Convention, in order to obtain, directly or indirectly, a financial or other material benefict". ${ }^{194}$

${ }^{191}$ Jean-Paul Laborde, État de droit et crime organisé. Paris: Dalloz, 2005, p. 147.

${ }^{192}$ Rodrigo Carneiro Gomes, O crime organizado..., ob. cit., p. 23.

${ }^{193}$ Rodrigo Carneiro Gomes, O crime organizado..., ob. cit., p. 25.

${ }^{194}$ Neste trabalho, utilizaremos os conceitos oferecidos pela Convenção de Palermo em seu original em inglês, uma vez que a tradução para o português apresenta diversas imprecisões, as quais acabam por comprometer seu significado final. O dispositivo em questão, por exemplo, foi traduzido da seguinte maneira:

“Art. $2^{o}$. a) 'Grupo criminoso organizado' - grupo estruturado de três ou mais pessoas, existente há algum tempo e atuando concertadamente com o propósito de cometer uma ou mais infrações graves ou enunciadas na presente Convenção, com a intenção de obter, direta ou indiretamente, um benefício econômico ou outro benefício material".

Nota-se, dessa forma, que, enquanto a redação original determina que apenas será considerado crime organizado a ação do grupo de indivíduos que se dedicar a cometer crimes graves constantes na Convenção ("with the aim of committing one or more serious crimes or offences established in accordance with this Convention"), a tradução para o português erroneamente introduziu uma relação de alternatividade inexistente no dispositivo paradigma ("com o propósito de cometer uma ou mais infrações graves OU 
Assim, pode-se afirmar serem elementos essenciais do conceito de crime organizado oferecido pela Convenção de Palermo: i) o número mínimo de integrantes (três ou mais pessoas); ii) a permanência no tempo; iii) a atuação de forma combinada; iv) o cometimento de infrações graves ${ }^{195}$ previstas especificamente na própria Convenção ${ }^{196}$; v) atuação com objetivo de obtenção, de maneira direta ou indireta, de vantagem financeira ou material. ${ }^{197}$

É importante notar, porém, que, apesar de a Convenção de Palermo ter sido incorporada ao ordenamento jurídico nacional, ela não traz tipos legais já pré-definidos, e sim inaugura a obrigação jurídica internacional por parte do legislador pátrio de criar proposições legislativas que atendam e observem as diretrizes propostas pelo referido documento. É certo dizer, dessa forma, que a incorporação da Convenção de Palermo ao ordenamento jurídico pátrio aponta os elementos essenciais da definição de crime organizado - vale dizer, traz recomendações ${ }^{198}$-, mas não supre a necessidade da

enunciadas na presente Convenção"). Como resultado, a "versão brasileira" da Convenção de Palermo abrange na categoria "criminalidade organizada", além dos crimes previstos na Convenção, também os crimes graves não previstos no documento - uma ampliação de espectro que não encontra correspondência na versão original.

Além disso, conforme lembra Antônio Sérgio Altieri de Moraes Pitombo, a referida tradução para o português peca, ainda, pelo desconhecimento da técnica do direito penal, existindo, no texto em português do documento, deslizes como a conduta chamada de "participar ativamente", expressão que se encontra em dissonância com o artigo 29 do Código Penal, uma vez que não corresponde à dicotomia autoria/participação (Antônio Sérgio Altieri de Moraes Pitombo, Organização criminosa..., ob. cit., p. 108).

${ }^{195}$ A própria Convenção de Palermo define, em seu artigo $2^{\circ}, b$, o que seriam infrações graves, como se lê:

“Art. $2^{o}$. (b). 'Serious crime' shall mean conduct constituting na offence punishable by a maximum deprivation of liberty of at least four years or a more serious penalty”.

${ }^{196}$ Os crimes previstos na Convenção de Palermo são: participação em grupo criminoso organizado (art. $5^{\circ}$ ), lavagem de dinheiro (art. $6^{\circ}$ ), corrupção (art. $8^{\circ}$ ) e obstrução da Justiça (art. 23) - neste último, compreendese o uso da violência, ameaças, intimidação ou promessas, oferecimento ou concessão de valores para induzir falso testemunho ou para interferir em declarações testemunhais ou na produção de provas no curso de processos relacionados ao cometimento de delitos previstos pela Convenção; e também o uso da violência, ameaças ou outras formas de intimidação contra juízes ou agentes do judiciário. (Piero L. Vigna, La cooperación judicial frente al crimen organizado. In: El crimen organizado - Desafíos y perspectivas en el marco de la globalización. Buenos Aires: Editorial Ábaco de Rodolfo Depalma, 2005, p. 235).

${ }^{197}$ Rodrigo Carneiro Gomes aponta, ainda, como característica essencial do conceito de crime organizado apresentado pela Convenção de Palermo, a transnacionalidade do delito, no que é acompanhado por Luís Flávio Gomes, o qual considera ser "da essência dessa definição a natureza transnacional do delito (logo, delito interno, ainda que organizado, não se encaixa nessa definição)”. (Luis Flávio Gomes, Definição de crime organizado e a Convenção de Palermo. Artigo disponível no endereço eletrônico http://www.lfg.com.br em 06 de maio de 2009). Contudo, e com todo o respeito às opiniões divergentes, cremos que tal entendimento não procede, uma vez que a própria Convenção, em seu artigo 34, 2, estabelece que os delitos nela previstos - inclusive o de participação em organização criminosa - podem ser estabelecidos nas leis internas dos Estados-membros independentemente de sua natureza transnacional.

198 Para Rodrigo Carneiro Gomes, algumas das principais recomendações trazidas pela Convenção de Palermo tratam da penalização dos delitos cometidos por grupos criminosos organizados - incluindo até 
criação de lei penal em sentido estrito. ${ }^{199}$

Nesse sentido, o artigo $5^{\circ}$ da Convenção determina que seus Estados-membros devem adotar medidas - legislativas ou extra-legislativas - para criminalizar a conduta de participação em organização criminosa, como se vê:

"Art. 5. 1. Each State Party shall adopt such legislative and other measures as may be necessary to establish as criminal offences, when commited intentionally:

(a) Either or both of the following as criminal offences distinct from those involving the attempt or completion of the criminal activity:

(i) Agreeing with one or more other persons to commit a serious crime for a purpose relating directly or indirectly to the obtaining of a financial or other material banafit and, where required by domestic law, involving an act undertaken by one of the participants in furtherance of the agreement or involving an organized criminal group;

(ii) Conduct by a person who, with knowledge of either the aim and general criminal activity of an organized criminal group or its intention to commit the crimes in question, takes the active part in:

a. Criminal activities of the organized criminal group;

b. Other activities of the organized criminal group in the knowledge that his or her participation will contribute to achievement of the above-described criminal aim;

(b) Organizing, directing, aiding, abetting, facilitating or counseling the commission of serious crime involving an organized criminal group.

mesmo a responsabilização penal da pessoa jurídica - e da adoção de medidas para a utilização de técnicas especiais de investigação, tais como a ação controlada, a vigilância eletrônica e a infiltração de agentes. (Rodrigo Carneiro Gomes, $O$ crime organizado..., ob. cit., pp. 35-36).

${ }^{199}$ Rodrigo Carneiro Gomes, O crime organizado..., ob. cit., p. 19. 
2. The knowledge, intent, aim, purpose or agreement referred to in paragraph 1 of this article may be inferred from objective factual circumstances.

3. State Parties whose domestic law requires involvement of an organized criminal group for purposes of the offences established in accordance with paragraph 1 (a) (i) of this article shall ensure that their domestic law covers all serious crimes involving organized criminal groups. Such State Parties, as well as State Parties whose domestic law requires an act in furtherance of the agreement for purposes of the offences established in accordance with paragraph 1 (a) (i) of this article, shall so inform tha SecretaryGeneral of the United Nations at the time of their signature or of deposit of their instrument of ratification, acceptance or approval of or accession to this Convention".

Como se percebe, a Convenção não traz pronto o tipo penal de participação em organização criminosa, mas, sim, apresenta uma série de recomendações ao Estado-parte para que este possa criar, em seu próprio ordenamento jurídico, um tipo penal que esteja de acordo com tais diretrizes.

\subsubsection{A imprescindibilidade da definição jurídico-penal da criminalidade organizada.}

Ante todo o exposto, e face à mutabilidade e à dificuldade de conceituação jurídico-penal do fenômeno da criminalidade organizada, alguns autores chegam a sustentar a desnecessidade, ou mesmo a insensatez, de formular-se tal definição. Francis Rafael Beck, por exemplo, considera que a referida conceituação, no atual estágio dos estudos criminológicos, não seria razoável ou segura, podendo resultar restrita ou ampla em demasia. Ainda, segundo o autor, "a própria mutabilidade do fenômeno impede esta restrição. Qualquer conceito que poderia ser utilizado há duas ou três décadas certamente não se adequaria à maior parte dos casos atuais de suposta existência de criminalidade organizada. Com a globalização da 
economia e a revolução das formas de comunicação e transferência de dados $e$ informações, mesmo um conceito formulado há poucos anos já poderia restar completamente desatualizado, obsoleto". ${ }^{200} \mathrm{Na}$ mesma linha, Adhemar Ferreira Maciel sustenta que "a Lei 9.034 não define, no que faz bem, o que seja uma 'organização criminosa', afinal não se trata de uma figura típica. O conceito de 'organização criminosa' deve ficar, assim, por conta da doutrina e da jurisprudência"201. Eugenio Raúl Zaffaroni, por sua vez, comenta ser impossível existir um único conceito que abarque todas as variantes de um fenômeno tão heterogêneo quanto o crime organizado e que, ainda assim, tenha alguma utilidade ${ }^{202}$ : “fenômenos tan heterogêneos deben ser combatidos com medidas particularizadas, adecuadas a las características de cada uno; de lo contrario, todos los intentos nacen destinados al fracaso. Siendo ello así, no veo la utilidad de uma categoria que los abarque a todos, que además es tan borrosa que a veces deja fuera a algunos e incluye a otros. Nada se gana com pretender tratar del mismo modo el secuestro y la lobrefacturación. Si la categorización no sirve para combatir el fenómeno, cabe perguntarse para qué se la usa"203.204

Não concordamos, contudo, com tais entendimentos. Pensamos que a razão precisa superar o medo de conceituar juridicamente as organizações criminosas, de forma que tal definição passe a fazer parte de nosso corpo legal; atrelada, ainda, a pressupostos conectados às liberdades individuais. ${ }^{205}$

Dessa forma, entendemos que apenas a existência da conceituação legal do fenômeno da criminalidade organizada pode autorizar o emprego de meios de investigação de provas que acarretem a restrição de direitos e garantias do cidadão - tais como a infiltração de agentes, objeto deste trabalho -, nos termos do

\footnotetext{
${ }^{200}$ Francis Rafael Beck, Perspectivas..., ob. cit., pp. 73-74.

${ }^{201}$ Adhemar Ferreira Maciel, Observações sobre a lei de repressão ao crime organizado. Revista Brasileira de Ciências Criminais. São Paulo: Revista dos Tribunais, out.-dez.1995.

${ }^{202}$ Eugenio Raúl Zaffaroni, En torno al concepto de “crimen organizado". In: Nada personal... Ensayos sobre crimen organizado y sistema de justicia. Buenos Aires: Depalma, 2001, p. 10.

${ }^{203}$ Eugenio Raúl Zaffaroni, En torno al concepto..., ob. cit., p. 10.

${ }^{204}$ No mesmo sentido, ver também: Gamil Föppel El Hireche, Análise criminológica das organizações criminosas: da inexistência à impossibilidade de conceituação e suas repeercussões no ordenamento jurídico pátrio. Manifestação do direito penal do inimigo. Rio de Janeiro: Lumen Juris, 2005.

${ }^{205}$ Antônio Sérgio Altieri de Moraes Pitombo, Organização criminosa..., ob. cit., p. 157.
} 
princípio da legalidade ${ }^{206}$ de acordo com o qual não se pode empregar meios investigação excepcionais, que restrinjam direitos fundamentais do indivíduos, sem que o crime que tais meios pretendam reprimir esteja previsto em lei anterior. Nesse sentido, afirma Antonio Scarance Fernandes: “a falta de definição de organização criminosa impossibilita a restrição a direitos e garantias do investigado, do acusado, do condenado, com fundamento no fato de pertencer a esse tipo de entidade, por ofensa aos princípios da reserva legal e da proporcionalidade". ${ }^{207}$ Sem tal lei anterior, de fato, o emprego dos referidos meios seria mesmo destituído de validade e eficácia. $\mathrm{O}$ conceito de organização criminosa permitiria, assim, a manutenção da ordem constitucional, atribuindo eficácia às leis criadas com o objetivo de reprimir o crime organizado. $^{208}$

A definição é necessária, também, para que se saiba quais os limites que devem ser seguidos em caso de uma ação investigativa em que haja eventual restrição de garantias fundamentais. ${ }^{209}$ Conforme afirma Rafael Pacheco, “se, de um lado, clama-se pela necessidade de repressão e de meios investigatórios contra o crime organizado, parece salutar que haja uma definição concreta do que seja uma organização criminosa, para, dessa forma, evitar uma extensão descontrolada do uso desses meios". ${ }^{210}$ No mesmo sentido, a lição de Yann Bisiou: "Um travail de définition de la notion de crime organisé est indispensable pour justifier des atteintes aux libertes individuelles acceptables dans une société démocratique”. 211

\footnotetext{
${ }^{206}$ De acordo com Rogério Lauria Tucci, o princípio (ou ditame, segundo o autor) da legalidade relaciona-se com a função garantista da lei penal, abrangendo a proibição de retroatividade ("nullum crimen, nulla poena sine praevia lege”), a proibição da analogia incriminatória, a proibição do recurso ao direito consuetudinário, e a necessidade de determinação da lei penal (princípio da legalidade em sentido estrito). Tal princípio pressupõe, dessa forma, a existência de uma lei penal estrita, anterior, certa e estrita. Trata-se, dessa forma, de uma rígida limitação ao direito de punir ("ius puniendi") do Estado, face ao direito de liberdade ("ius libertatis") do indivíduo integrante da comunidade, que se consolidou como uma conquista do direito penal liberal. No ordenamento brasileiro, está expresso no artigo $5^{\circ}$, inciso XXXIX, de nossa Constituição Federal, verbis: "não há crime sem lei anterior que o defina, nem pena sem prévia cominação legal”. (Rogério Lauria Tucci, Direitos e garantias individuais no processo penal brasileiro. São Paulo: Revista dos Tribunais, 2004, p. 289-290).

207 Antonio Scarance Fernandes, O equilíbrio na repressão ao crime organizado. In: Crime organizado aspectos processuais. São Paulo: Revista dos Tribunais, 2009, p. 15.

${ }^{208}$ Rafael Pacheco, Crime organizado..., ob. cit., p. 58.

${ }^{209}$ Rafael Pacheco, Crime organizado..., ob. cit., p. 58.

${ }^{210}$ Rafael Pacheco, Crime organizado..., ob. cit., p. 58.

211 Yann Bisiou, Le concept de crime organisé em France. In: Criminalité organisée - des représentations sociales aux définitions juridiques. Paris: L.G.D.J; Bruxelles: Bruylant; Genève: Georg, 2004, p. 645.
} 
Além disso, apenas a elaboração do modelo legal de organização criminosa pode conferir a necessária segurança jurídica ao direito pátrio, pondo termo à aplicação subsidiária do crime de quadrilha ou bando e restringindo o campo de aplicação da norma penal. ${ }^{212}$ Ademais, deve-se considerar que a taxatividade da lei penal limita o poder estatal, garantido a vinculação dos magistrados à letra da lei; impedindo-se, dessa forma, práticas judiciais incompatíveis com o direito penal de cunho democrático. ${ }^{213}$

Por fim, faz-se necessário destacar que, respeitando-se o princípio da legalidade, veda-se o bis in idem $^{214}$, ou seja, garante-se ao indivíduo que ele não será processado duas vezes pelo mesmo fato, graças à aplicação concreta das normas abstratas. Assim, a definição legal de organização criminosa precisa levar em conta os tipos em vigor, para não dobrar as consequiências jurídicas advindas de um acontecimento único. $^{215}$

Nesse sentido, ressalta Antônio Sérgio Altieri de Moraes Pitombo: "A falta de tipo legal põe os operadores do direito sob risco de padecerem com a arbitrariedade judicial, dada a perda da garantia da reserva legal. O desprezo à união entre direito e processo penal compõe mais um aspecto de temor, porque a persecução passa a ter valor não pelo fim justo, mas pela satisfação de empregar esses meios contra determinadas pessoas, em nome de falsos ideais de proteção a interesse, paz, segurança, ou ordem pública. Impossível imaginar o due process of law em persecução penal que apura fato, indefinido pela lei, mediante atos investigatórios (art. $2^{\circ}$ da Lei 9.034/1995) $e$ procedimentos (art. $3^{\circ}$ da Lei 9.034/95) que desrespeitam direitos e garantias inerentes ao processo penal. E tal descuido quanto à legalidade, como fundamento do Estado

${ }^{212}$ Antônio Sérgio Altieri de Moraes Pitombo, Organização criminosa..., ob. cit., p. 156.

${ }^{213}$ Antônio Sérgio Altieri de Moraes Pitombo, Organização criminosa..., ob. cit., p. 158.

${ }^{214} \mathrm{O}$ ne bis in idem (ou non bis in idem) configura, também, uma garantia do acusado, referente à necessidade da persecução penal. O Estado não pode submeter um acusado a processo por duas vezes, pelo mesmo fato, seja de forma simultânea ou sucessiva; ou seja, a intervenção do aparato estatal em busca de uma condenação apenas pode ser posta em marcha uma vez. Isto significa que a pessoa não pode ser submetida a uma dupla condenação nem correr o risco de isso acontecer. (Alberto M. Binder, Introdução..., ob. cit., p. 125). No entanto, é importante destacar que isso não significa que ela não possa ser submetida a um segundo processo pelos mesmos fatos, dadas determinadas condições, como lembra Alberto M. Binder: "[a pessoa] pode ser submetida a um segundo processo se o motivo deste último consiste em revisar a sentença condenatória do primeiro para determinar se é admissível uma revogação da sentença ou uma absolvição. $O$ inadmissível, portanto, não é a repetição do processo, mas uma dupla condenação ou o risco de que este fato ocorra”. (Alberto M. Binder, Introdução..., ob. cit., p. 125).

${ }^{215}$ Antônio Sérgio Altieri de Moraes Pitombo, Organização criminosa..., ob. cit., p. 160. 
Democrático de Direito, (art. $5^{\circ}, X X X I V$, da CF c/c o art. $1^{o}$ do $C P$ ), significa violar a própria regra da separação das três fazes do poder estatal (art. $2^{\circ}$ da CF)", ${ }^{216}$

${ }^{216}$ Antônio Sérgio Altieri de Moraes Pitombo, Organização criminosa..., ob. cit., pp. 113-114. 


\section{CAPÍTULO 2 - CRIMINALIDADE ORGANIZADA E PROVA}

Como se pode depreender do exposto até o momento, as leis elaboradas acerca do tema "criminalidade organizada" pelo legislador brasileiro trazem inúmeras inovações ao nosso ordenamento jurídico. Tais inovações vão desde a - tentativa de - criação de um novo tipo penal, até o momento, porém, sem sucesso -, até a implementação de diversos novos meios de investigação de prova, a serem empregados exclusivamente nos delitos relacionados ao crime organizado - dentre os quais, encontra-se a infiltração de agentes policiais, tema deste trabalho.

Para melhor analisar este tema, de maneira específica, exsurge necessário abordar, primeiramente, de maneira geral, a problemática das provas no processo penal ${ }^{217}$; com a intenção de facultarmos, com isso, a análise posterior de admissibilidade no processo das provas produzidas por meio da infiltração de agentes.

\subsection{Prova.}

O vocábulo "prova", tanto na linguagem leiga, quanto na científica ou jurídica, é sabidamente polissêmico. ${ }^{218}$ Etimologicamente, ele possui a mesma origem da palavra "probo" - a qual, por sua vez, deriva do latim "probatio" e "probus" -, traduzindo, assim, a idéia de aprovação, confiança, correção. Relaciona-se, de forma ampla, com o campo da filosofia, ao vasto campo das operações do intelecto

217 O tema "prova" é dos mais importantes da ciência do processo, uma vez que "a correta verificação dos fatos em que se assentam as pretensões das partes é pressuposto fundamental para a prolação da decisão justa. Isso vale, ainda mais, no âmbito penal, pois só a prova caval do fato criminoso é capaz de superar a presunção de inocência do acusado, que representa a maior garantia do cidadão contra o uso arbitrário do poder punitivo" (Antonio Magalhães Gomes Filho, Notas sobre a terminologia da prova (reflexos no processo penal brasileiro). In: Estudos em homenagem à professora Ada Pellegrini Grinover. Org.: Flávio Luiz Yarshell e Maurício Zanóide de Moraes. São Paulo: DPJ, 2005, p. 303).

${ }^{218}$ Antonio Magalhães Gomes Filho e Gustavo Henrique Righi Ivahy Badaró, Prova e sucedâneos de prova no processo penal brasileiro. Revista Brasileira de Ciências Criminais. São Paulo, v. 15, fasc. 65, mar.abr./2007, p. 175. 
em busca do conhecimento verdadeiro, bem como na sua comunicação. ${ }^{219}$ Ainda no sentido extraprocessual, Antonio Magalhães Gomes Filho distingue três acepções do termo: i) como demonstração - quando se diz que ela é utilizada para estabelecer a verdade $^{220}$ sobre determinados fatos -; ii) como experimentação - quando significa uma atividade ou procedimento que objetiva verificar a correção de uma hipótese ou afirmação -; e iii) como desafio ou competição - quando indica um obstáculo que deve ser superado. ${ }^{221}$

Pode-se, também, distinguir os diversos significados do termo "prova" no sentido processual com a mesma divisão empregada por Antonio Magalhães Gomes Filho no sentido extraprocessual: demonstração, experimentação e desafio. Assim, segundo o autor, a "demonstração", em sentido processual, se ligaria à apresentação de dados de conhecimento idôneos para admitir-se como verdadeiro um enunciado sobre um determinado fato. A "experimentação", por sua vez, estaria relacionada, em seu sentido processual, à pesquisa que se faz, na fase processual de instrução probatória, com o objetivo de recolher e analisar os elementos necessários para confirmar - ou não - as assertivas feitas sobre determinados fatos, pelas partes ou pelo juiz. Por fim, o "desafio" relaciona-se ao ônus da prova, ou seja, ao encargo que incumbe à parte, para demonstrar aquilo que alega. ${ }^{222}$

$\mathrm{Na}$ terminologia processual, por sua vez, a mesma expressão também apresenta sentidos diversos: i) indica, de forma mais ampla, o conjunto de atividades levadas a cabo pelo juiz e pelas partes na reconstituição dos

\footnotetext{
${ }^{219}$ Antonio Magalhães Gomes Filho, Direito à prova no processo penal. São Paulo: Revista dos Tribunais, 1997, p. 41.

${ }^{220}$ Muito se discute na doutrina acerca da "verdade" que seria possível ser encontrada em um processo judicial. Costuma-se afirmar que, no processo civil, aplica-se a denominada "verdade formal", que prestigia uma política de celeridade em detrimento de um acertamento fático, enquanto que o processo penal exige o alcance da chamada "verdade material" ou "verdade real". Esta última "é aquela cujas proposições legais são as mais próximas possíveis da certeza, ou seja, livres de presunções legais de qualquer espécie. (...) Ao contrário do que sucede com a verdade formal, aqui não se trata de uma verdade obtida a partir de elementos metaprocessuais trazidos pelas partes, ou do fruto de presunções e formalidades referentes à prova. A verdade material é pesquisada de forma mais aprofundada, permitindo o ordenamento jurídico processual, inclusive, a realização de diligências ex officio pelo julgador, tudo com o objetivo de melhor elucidar os fatos e, por via de conseqüência, para uma prestação jurisdicional de qualidade e compatível com os ditames do due process of law e com os postulados da Justiça”. (Luis Fernando Silveira Beraldo, Limites aos poderes instrutórios do juiz criminal. Dissertação de mestrado apresentada perante a Faculdade de Direito da Universidade de São Paulo, São Paulo: USP, 2006, p. 28).

${ }^{221}$ Antonio Magalhães Gomes Filho, Notas sobre a terminologia da prova..., ob. cit., p. 305.

${ }^{222}$ Antonio Magalhães Gomes Filho, Notas sobre a terminologia da prova..., ob. cit., p. 306.
} 
fatos que suportam as pretensões aduzidas, bem como a própria decisão; ii) faz referência aos instrumentos por meio dos quais as informações sobre os fatos são introduzidas no processo ("meios de prova"); e, por fim, iii) aponta o resultado das referidas atividades. ${ }^{223}$

Pode-se dizer que prova exerce desse modo, no processo judicial, a função de ser um instrumento para a fundamentação racional da escolha, por parte do magistrado, de uma versão dos fatos que se possa definir como verdadeira. ${ }^{224}$ Em sentido amplo, “è prova qualsiasi strumento funzionalmente destinato alla verifica di enunciati fattuali”. ${ }^{225}$

\subsubsection{Elemento de prova e resultado de prova.}

No âmbito processual, a palavra "prova" é empregada, ainda, para designar os dados objetivos que confirmam ou negam uma assertiva elaborada acerca de um fato relevante ao deslinde da causa. ${ }^{226}$ Nesse sentido, é entendida como elemento de prova. ${ }^{227}$

Tais elementos de prova, por sua vez, servem como base para que o juiz competente forme suas conclusões acerca do caso que julga, por meio de movimentos inferenciais. ${ }^{228}$ Logo, no sentido da própria conclusão que se extrai dos diversos elementos de prova existentes acerca de determinado fato, a palavra prova

\footnotetext{
${ }^{223}$ Antonio Magalhães Gomes Filho, Direito à prova..., ob. cit., pp. 41-42.

${ }^{224}$ Gustavo Henrique Righi Ivahy Badaró, Ônus da prova no processo penal. São Paulo: Revista dos Tribunais, 2003, p. 161. O mesmo autor assevera, ainda, que: "embora o problema do acertamento judicial dos fatos não se coloque em termos de determinação da verdade absoluta ou da certeza indubitável de uma determinada alegação fática, a prova se coloca como um mecanismo que permite que se realize uma escolha racional entre hipóteses diversas sobre os fatos debatidos no processo. No processo há vários fatores relevantes, ou melhor várias hipóteses ou enunciados sobre fatos relevantes. É a prova que fornece o 'grau de suporte', ou 'de confirmação', ou ainda 'de convencimento', de uma das hipóteses fáticas relevantes para a decisão da causa”. (Gustavo Henrique Righi Ivahy Badaró, Ônus da prova..., ob. cit., pp. 161-162).

${ }^{225}$ Antonio Laronga, Le prove atipiche nel processo penale. Milano: CEDAM, 2002, p. 14.

${ }^{226}$ Antonio Magalhães Gomes Filho, Notas sobre a terminologia da prova..., ob. cit., p. 307.

${ }^{227}$ Antonio Magalhães Gomes Filho, Notas sobre a terminologia da prova..., ob. cit., p. 307.

${ }^{228}$ Antonio Magalhães Gomes Filho, Notas sobre a terminologia da prova..., ob. cit., p. 307.
} 
assume nova significação: ela é o resultado de prova ${ }^{229}$, o qual é obtido tanto pela soma daqueles elementos quanto pelo movimento intelectual feito pelo juiz, para estabelecer se a afirmação feita é verdadeira ou não. ${ }^{230}$

\subsubsection{Objeto de prova.}

O objeto de prova (thema probandum) pode ser entendido como os fatos ${ }^{231}$ que interessam à solução de um caso submetido à apreciação judicial. Para Vicenzo Manzini, o objeto da prova é o conjunto de todos os fatos, principais ou secundários, que interessam a uma providência a ser tomada pelo juiz e que exijam comprovação. $^{232}$

Note-se que, conforme destaca Antonio Magalhães Gomes Filho, a prova, no processo penal, não versa apenas sobre a realidade fática como tal: ela tem por objetivo reconstruir os fatos na medida em que eles constituam pressupostos para a aplicação do direito. Assim, o objeto da prova, no processo penal, são os fatos interpretados de acordo com os tipos penais. ${ }^{233} \mathrm{O}$ autor ressalta, ainda, que o que se apura no processo é a verdade ou falsidade de uma afirmação sobre um fato, e não do fato em si, uma vez que é impossível provar um acontecimento já passado e findo. ${ }^{234}$ Assim, tem-se que "no processo penal, a atividade probatória versa, fundamentalmente, sobre a imputação de um fato criminoso, ou seja, sobre a afirmação que faz a acusação a respeito da ocorrência de um fato tipificado pelo direito penal. Assim, a qualificação jurídica também integra a imputação, na medida em que o fato narrado só tem valor quando ligado à norma incriminadora”. 235

${ }^{229}$ Antonio Magalhães Gomes Filho, Notas sobre a terminologia da prova..., ob. cit., p. 308.

${ }^{230}$ Antonio Magalhães Gomes Filho, Notas sobre a terminologia da prova..., ob. cit., p. 308.

${ }^{231} \mathrm{Ou}$, ainda, conforme lembra Hugo Alsina, a inexistência de um fato, como ocorre nas situações em que o acusado invoca um álibi em seu favor. (Hugo Alsina, Tratado teórico práctico de derecho procesal civil y comercial. Buenos Aires: Ediar, 1961, p. 224).

232 Vicenzo Manzini, Tratado de derecho procesal penal. Trad.: Santiago Sentís Melendo. Buenos Aires: Europa-América, 1951, p. 203.

233 Antonio Magalhães Gomes Filho, Notas sobre a terminologia da prova..., ob. cit., pp. 316-317.

${ }^{234}$ Antonio Magalhães Gomes Filho, Notas sobre a terminologia da prova..., ob. cit., pp. 316-317.

${ }^{235}$ Antonio Magalhães Gomes Filho, Notas sobre a terminologia da prova..., ob. cit., pp. 316-317. 
Note-se, porém, que não se busca, com o processo, conhecer a verdade sobre o fato $^{236} \mathrm{em} \mathrm{si,} \mathrm{mas} \mathrm{sim,} \mathrm{a} \mathrm{verdade} \mathrm{ou} \mathrm{falsidade} \mathrm{de} \mathrm{uma} \mathrm{afirmação} \mathrm{sobre}$ um fato; uma vez que o fato, sendo fenômeno do mundo real, apenas poderia ser constatado no próprio momento em que ocorre, não sendo possível a sua repetição. ${ }^{237}$ "Não é possível, portanto, provar um acontecimento passado, mas somente demonstrar se uma afirmação sobre este é ou não verdadeira",238.

De se ressaltar que, sendo o thema probandum determinado pelas proposições, feitas pelas partes, representativas do fato - ou seja, o fato interpretado , é fundamental que a pesquisa probatória seja intimamente ligada ao contraditório processual. ${ }^{239}$ Por essa razão, deve o juiz zelar sempre pela observância das garantias do contraditório e da ampla defesa, seja para que possa o acusado defender seu status libertatis, seja para que possa a acusação sustentar sua afirmação inicial. ${ }^{240}$

\subsubsection{Fontes de prova, meios de prova e meios de investigação de prova.}

Distinção importante a ser feita entre os significados do termo "prova" é, também, aquela entre as fontes de prova, os meios de prova e os meios de investigação de prova.

A expressão fonte de prova refere-se às pessoas ou coisas das quais se obtém a prova (ou melhor, o elemento de prova). As fontes de prova podem ser pessoas (a vítima, o acusado, testemunhas ou peritos), caso em que podem

\footnotetext{
${ }^{236}$ O termo "fato" pode ser entendido como tudo aquilo passível de ser objeto do conhecimento humano. (Hugo Alsina, Tratado teórico práctico..., ob. cit., p. 239). De acordo com Manzini, no processo penal podem constituir objeto de prova fatos controvertidos ou não, uma vez que, ao contrário do que ocorre no processo de natureza extrapenal, o juiz não está adstrito ao que dispõem as partes. (Vicenzo Manzini, Tratado de derecho procesal..., ob. cit., p. 204).

${ }^{237}$ Antonio Magalhães Gomes Filho, Notas sobre a terminologia da prova..., ob. cit., p. 316.

${ }^{238}$ Antonio Magalhães Gomes Filho, Notas sobre a terminologia da prova..., ob. cit., p. 316.

${ }^{239}$ Antonio Magalhães Gomes Filho, Notas sobre a terminologia da prova..., ob. cit., p. 316.

${ }^{240}$ Luís Fernando Silveira Beraldo, Limites aos poderes instrutórios do juiz criminal. Dissertação de mestrado apresentada à Faculdade de Direito da Universidade de São Paulo. São Paulo: USP, 2006, p. 38.
} 
ser chamadas de fontes pessoais; ou coisas (documentos, lato sensu), caso em que recebem o nome de fontes reais ${ }^{241}$.

O termo meios de prova, por sua vez, refere-se aos instrumentos ou atividades por meio dos quais os elementos de prova são introduzidos e fixados no processo - são os canais de informação de que se serve o juiz para formar seu conhecimento. Na lição de Luigi Paolo Comoglio, os meios de prova "sono tutti caratterizzati dall'attitudine ad offrire al guidice risultanze probatorie direttamente utilizzabili in sede di decisione, e quindi hanno in quel guidice Il loro naturale destinatário". ${ }^{242}$ É, assim, uma atividade endoprocessual, que se desenvolve perante o juiz, com o conhecimento e a participação das partes, sob o crivo do contraditório. ${ }^{243}$

Note-se que a distinção entre fonte e meio de prova é de fundamental importância, especialmente no âmbito do processo penal garantista, no qual é assegurado ao réu o direito de não produzir provas contra si mesmo. Conforme assevera Antonio Magalhães Gomes Filho, “o acusado será, eventualmente, fonte de prova, na medida em que trouxer voluntariamente elementos probatórios úteis à decisão; mas o seu interrogatório não poderá ser considerado meio de prova porque não constitui atividade destinada a tal finalidade, mas antes instrumento de defesa". ${ }^{244}$

Por fim, os meios de pesquisa ou de investigação de prova dizem respeito a certos procedimentos regulados pela lei, com o objetivo de obter provas materiais. Não são eles, em si, fontes de conhecimento, mas servem para adquirir os elementos de prova. Tais procedimentos são, em geral, extraprocessuais, geralmente desprovidos de contraditório ${ }^{245}$, e podem ser realizados por outros funcionários ligados à administração da justiça - como, por exemplo, policiais. ${ }^{246}$ Nas palavras de Luigi Paolo

\footnotetext{
${ }^{241}$ Antonio Magalhães Gomes Filho, Notas sobre a terminologia da prova..., ob. cit., p. 308.

${ }^{242}$ Luigi Paolo Comoglio, Lessico delle prove e modello accusatorio. Rivista di Diritto Processuale. Milano: CEDAM, ano L (segunda série), n. 4, out.-dez./1995, p. 1206.

243 Antonio Magalhães Gomes Filho, Notas sobre a terminologia da prova..., ob. cit., pp. 308-309.

${ }^{244}$ Magalhães Gomes Filho, Notas sobre a terminologia da prova..., ob. cit., p. 308. Sobre o interrogatório como instrumento de defesa, ver: Marta Saad, O direito de defesa no inquérito policial. São Paulo: Revista dos Tribunais, 2004.

${ }^{245}$ Uma vez que a surpresa é característica essencial para o sucesso dos procedimentos de investigação, sem a qual seria inviável a obtenção dos elementos de prova. (Antonio Magalhães Gomes Filho, Notas sobre a terminologia da prova..., ob. cit., pp. 309).

${ }^{246}$ Antonio Magalhães Gomes Filho, Notas sobre a terminologia da prova..., ob. cit., p. 309.
} 
Comoglio, os meios de pesquisa de prova "non sono de per sé fonti de convincimento, ma servono quali strumenti per acquisire cose materiali, tracce o dichiarasioni dotate di attitudine probatória”. ${ }^{247}$

\subsection{Meios de investigação de prova nos delitos relacionados à criminalidade organizada. A busca por métodos diferenciados de investigação.}

Conforme já foi explanado no Capítulo 2 deste trabalho, as leis criadas no Brasil com o intuito de tipificar e combater o crime organizado trouxeram ao nosso ordenamento uma vasta gama de inovações investigativas, com o objetivo de obter, com isso, elementos de prova contra a criminalidade organizada.

Tais inovações se fazem necessárias pois os meios tradicionais de investigação de prova já não se mostravam eficientes contra a nova criminalidade. Como visto, os atos praticados pelos membros das organizações criminosas são variados e complexos - ou seja, englobam diversos tipos penais -, e suas formas de interação "as tornam imunes à intromissão e devassa das instâncias de controlo social". ${ }^{248}$ Além disso, sua atuação é no sentido de eliminar ou alterar quaisquer provas existentes contra eles. São empregados, para tanto, desde métodos tradicionais, tais como a imposição da "lei do silêncio" sobre os integrantes da organização e sobre testemunhas em geral - o temor da vingança, naturalmente, dificulta a obtenção de prova oral nas investigações criminais que envolvem o crime organizado -, até o uso de tecnologias de ponta - em muitos casos, superiores às que dispõem as forças policiais -, conforme sustenta Isabel Sánchez García de Paz: "las organizaciones criminales se aprovechan de las ventajas de rapidez, eficacia y anonimato que proporcionan las nuevas tecnologias (teléfonos móviles, sistemas informáticos, Internet). Frente a ellas, los médios tradicionales de investigación y búsqueda de pruebas

\footnotetext{
${ }^{247}$ Luigi Paolo Comoglio, Lessico..., ob. cit., p. 1207.

${ }^{248}$ Manuel da Costa Andrade, Métodos ocultos de investigação (Plädoyer para uma teoria geral). Justiça penal portuguesa e brasileira - tendências de reforma. Colóquio em homenagem ao Instituto Brasileiro de Ciências Criminais. São Paulo: IBCCrim, 2008, p. 107.
} 
- por ejemplo, acerca de las propriedades y capitales de la organización criminal resultan ineficaces". 249

Nesse sentido, as observações de Marta Gómez de Liaño Fonseca-Herrero: "la lucha contra el crimen organizado precisa de unos adecuados médios de confrontación em el âmbito nacional. Las diferentes autoridades afrontan una delincuencia que, a diferencia de la delincuencia común, no solo compromete bienes jurídicos de titularidad individual, sino antes al contrario despliega sus efectos más dadiños dobre el sustema social, financero y político, y agravia entidades jurídicas diversas, tales como la vida, el médio ambiente, la salud pública u la economia. Las organizaciones criminales disponen, además, de abundantes medios conducentes a la perpetración de ilícitos, cuentan con un entramado de difícil acceso para combatir los centros de decisión, tienen material altamente sofisticado y sujetos de comprobada eficacia delictiva, recurren a la ingeniería financiera para ocultar el resultado de sus actuaciones y son el origen de nuevos tipos penales. Desde la perspectiva jurídico procesal, mucho mayor há de ser la incidencia em la cultura de supresión de la prueba que preside el modus operandi de estas asociaciones, y es que, si el imputado siempre há buscado no dejar huellas de su delito, el crimen organizado há elevado a ciencia este empeño. Pretender combatir esta modalidad delictiva con las mismas vias legales que las arbitradas para la delincuencia común, resultaria absolutamente inoperante”. 250

Assim sendo, foram trazidos para o âmbito da investigação em sede de crime organizado diversos meios de pesquisa de prova, tais como a quebra dos sigilos $^{251}$ fiscal e financeiro ${ }^{252}$, a interceptação ambiental ${ }^{253}$, a interceptação telefônica ${ }^{254}$, a

\footnotetext{
${ }^{249}$ Isabel Sánchez García de Paz, La criminalidad organizada..., ob. cit., p. 220.

250 Marta Gómez de Liaño Fonseca-Herrero, Criminalidad organizada y médios extraordinarios de investigación. Madrid: COLEX, 2004, pp. 40-41.

${ }^{251} \mathrm{O}$ sigilo financeiro pode ser definido como a "obrigação que têm os bancos de não revelar, salvo justa causa, as informações que venham a obter em virtude de sua atividade profissional” (Sérgio Carlos Covello, O sigilo bancário: com particular enfoque na sua tutela civil. São Paulo: Universitária do Direito, 2001, p. 86), e sua proteção legal advém da tutela constitucional ao direito à intimidade (artigo $5^{\circ}$, inciso $\mathrm{X}$, de nossa Constituição Federal). O sigilo fiscal, por sua vez, não se confunde com o financeiro e se configura como a "confidencialidade da situação tributária dos contribuintes, pessoas físicas ou jurídicas" (Juliana Garcia Belloque, Sigilo bancário - análise crítica da LC 105/2001. São Paulo: Revista dos Tribunais, 2003, p. 82), encontrando-se amparado legalmente no artigo 198 do Código Tributário Nacional. É importante destacar que medidas relacionadas à quebra dos sigilos fiscal e financeiro dos investigados têm especial importância no âmbito dos delitos relacionados à criminalidade organizada, uma vez que as organizações criminosas apresentam, via de regra, grandes rendimentos financeiros de origem ilícita, os quais são ou
} 
delação premiada ${ }^{255}$, e a ação controlada ${ }^{256}$; além, é claro, da infiltração de agentes policiais, a qual será estudada extensivamente no capítulo seguinte.

"lavados" - para retornar "lícitos" ao meio circulante -, ou "desaguados" em contas bancárias localizadas, via de regra, em "paraísos fiscais".

252 A doutrina emprega, com bastante freqüência, a expressão "sigilo bancário". No entanto, conforme assevera Maurício Zanóide de Moraes, tal expressão não é a mais acertada, sendo mais correto se falar em sigilo financeiro. Isso porque a LC 105 , de 10 de janeiro de 2001, que dispõe sobre o sigilo das operações financeiras, considera como instituições financeiras, além dos bancos de qualquer espécie, também as distribuidoras de valores mobiliários; as corretoras de câmbio e de valores mobiliários; as sociedades de crédito, financiamento e investimentos; as sociedades de crédito imobiliário; as administradoras de cartão de crédito; as sociedades de arrendamento mercantil; as administradoras de mercado de balcão organizado; as cooperativas de crédito; as associações de poupança e empréstimo; as bolsas de valores e de mercadorias e futuros; as entidades de liquidação e compensação; e outras sociedades que, em razão da natureza de suas operações, assim venham a ser consideradas pelo Conselho Monetário Nacional (artigo $1^{\circ}$, parágrafo $1^{\circ}$ ). Dessa forma, a expressão "sigilo bancário" não oferece a abrangência adequada ao instituto em exame. (Maurício Zanóide de Moraes, Sigilo financeiro: LC 105, de 10.01.2001. In: Leis penais especiais e sua interpretação jurisprudencial. Org.: Alberto Silva Franco e Rui Stocco. São Paulo: Revista dos Tribunais, 2001, p. 2.797). Concordando com o referido autor, adotaremos neste trabalho a terminologia por ele sugerida.

${ }^{253}$ A interceptação ambiental - ou vigilância eletrônica, como também é chamada - consiste na "gravação sub-reptícia de conversa entre presentes realizada por terceiro no ambiente em que os interlocutores se encontram" (André Augusto Mendes Machado e André Pires de Andrade Kehdi. Sigilo das comunicações e de dados. In: Sigilo no processo penal - eficiência e garantismo. Coord.: Antonio Scarance Fernandes, José Raul Gavião de Almeida e Maurício Zanóide de Moraes. São Paulo: Revista dos Tribunais, 2008, p. 257). Tal meio de investigação permite que sejam instalados aparelhos de captação e gravação de som e imagem em ambientes fechados ou abertos, com a finalidade tanto de gravar os diálogos mantidos entre os investigados quanto de filmar as condutas por eles desenvolvidas. Além disso, podem ser registrados os sinais emitidos por aparelhos de comunicação que porventura os investigados estejam utilizando, tais como rádios transmissores. (Eduardo Araújo da Silva, Crime organizado..., ob. cit., p. 104).

254 A interceptação telefônica é regulamentada, no Brasil, pela lei n. 9.296, de 24 de julho de 1996, e depende, para ser autorizada pelo magistrado, de três requisitos, quais sejam: a presença, no caso em análise, de indícios suficientes de autoria e participação e da ocorrência (materialidade) da infração penal (fummus boni iuris ou, mais acertadamente, fummus comissi delicti); a impossibilidade de a prova pretendida ser obtida por outros meios investigatórios; e, finalmente, que o crime investigado seja punido com pena de reclusão. A medida tem, dessa forma, natureza claramente cautelar. (Antonio Scarance Fernandes, $O$ processo penal constitucional. São Paulo: RT, 2005, p. 105). Além disso, tendo em vista a cautelaridade da medida, deve-se observar, ainda, o periculum in mora, ou seja, a necessidade de a interceptação ser efetuada enquanto a conversa telefônica se desenvolve, sob pena de a prova ser perdida. (Antonio Magalhães Gomes Filho, Antonio Scarance Fernandes e Ada Pellegrini Grinover, As nulidades..., ob. cit., p. 220). Por fim, é necessário que se destaque a imperiosidade de que a interceptação telefônica seja realizada apenas para a persecução de crimes já em andamento, e jamais para a investigação de crimes cuja execução ainda deve se iniciar. Assim, restam vedadas as interceptações preventivas ou "exploratórias", desconectadas de um fato delituoso concreto, uma vez que a restrição ao direito à intimidade, de maneira indiscriminada, seria contrária ao sistema de garantias constitucionais - o qual também se estende à fase de inquérito. (José María Paz Rúbio et al, La prueba en el proceso penal - su práctica ante los tribunales. Madri: Colex: 1999, p. 223).

${ }^{255}$ Entende-se a delação premiada (também conhecida como denúncia, colaboração ou confissão espontânea, colaboração efetiva e voluntária, colaboração voluntária, revelação espontânea, revelação eficaz), resumidamente, como o oferecimento de um "prêmio" - que se traduz, em linguagem processual, conforme o caso, na redução, suspensão ou substituição da pena restritiva de liberdade, na extinção da punibilidade do agente ou no sobrestamento do processo - ao delator que, como autor, co-autor ou partícipe, colaborar com a autoridade policial ou judiciária na coleta de provas que leve, de forma eficaz, à apuração da infração penal e de sua autoria. A delação é endereçada, em geral, à autoridade policial ou judicial, não existindo óbice, porém, a que seja direcionada também ao representante do Ministério Público. 


\subsubsection{Natureza jurídica.}

(Maria Thereza Rocha de Assis Moura, Delação premiada. Revista Del Rey Jurídica. Belo Horizonte, ano 8, n. $16,1^{\circ}$ sem./2006, pp. 69-70). A delação premiada é prevista em diversos diplomas legais em nosso país; porém, com o advento da Lei n. 9.807, de 1999, que estabelece normas para a proteção às vítimas, testemunhas e aos réus colaboradores ameaçados, a delação premiada passou a abranger todos os crimes de nosso ordenamento jurídico, desde que preenchidos determinados requisitos, que devem ser alternativamente considerados, quais sejam: i) a voluntariedade da colaboração do acusado para com a investigação ou com o processo criminal, vedando-se assim a sua obtenção por meio de coação externa; ii) a relevância e eficácia dessa colaboração, sendo que a partir das declarações do investigado deve ter sido possível a descoberta da materialidade e da autoria do delito; e iii) em alguns casos, a personalidade do investigado e as circunstâncias do delito por ele cometido (requisito subjetivo). Nesse sentido, Maria Thereza Rocha de Assis Moura, Delação premiada, ob. cit., p. 70, e David Teixeira de Azevedo, A colaboração premiada num direito ético. Boletim IBCCrim. São Paulo, n. 83, out. 1999; Thereza Rocha de Assis Moura, Delação premiada, ob. cit., p. 70; e Eduardo Araújo da Silva, Crime organizado..., ob. cit., p. 83.

Note-se, porém, que, muito embora esteja previsto com tamanha abrangência em nosso ordenamento, a delação premiada nunca teve grande aplicação prática, tendo sido alvo de inúmeras críticas por parte da doutrina, haja visto o entendimento majoritário de que se consubstancia em uma transgressão ética e em um ato de traição, e que sua concessão significaria "barganhar"com a criminalidade e premiar o criminoso; de que viola o princípio de que a pena deve ser imposta na medida da culpabilidade do agente, sendo, em última análise, inconstitucional; e que, em suma, reflete um sistema penal falido, incapaz de desmantelar organizações criminosas e solucionar delitos com base em seus próprios métodos investigativos. (Maria Thereza Rocha de Assis Moura, Delação premiada, ob. cit., p. 67). Some-se a isso, ainda, a relutância dos próprios investigados em fazer uso do benefício, por receio de que, a par da condenação, passará a ser objeto de vingança dos companheiros "delatados". (Damásio E. de Jesus, O fracasso da delação premiada. Boletim IBCCrim. São Paulo, n. 21, set./1994). Por outro lado, no entanto, há que se considerar que, em que pese o questionamento acerca da moralidade do instituto, ele traz consigo a indiscutível vantagem de permitir ao Estado quebrar licitamente a lei do silêncio que envolve as organizações criminosas - daí, por certo, a sua utilidade para a investigação dos crimes ligados à criminalidade organizada, nos quais, como visto, a lei do silêncio impera. (Eduardo Araújo da Silva, Da moralidade da proteção aos réus colaboradores. Boletim IBCCrim. São Paulo, n. 85, dez./1999).

${ }^{256}$ A ação controlada é método de investigação de prova de aplicação exclusiva para os delitos ligados à criminalidade organizada e ao tráfico de drogas. Ele permite aos agentes policiais retardarem suas intervenções em relação a infrações em curso, praticadas por organizações criminosas, para que possam acompanhar os atos praticados por seus membros até o momento mais apropriado do ponto de vista da colheita dos elementos probatórios e eficácia das prisões. Assim, é facultado ao policial que deixe de efetuar a prisão em flagrante no momento em que presencia a prática do delito ("espera" que recebe o nome de flagrante diferido, retardado ou prorrogado), aguardando momento mais propício para agir e, dessa forma, obter mais elementos de prova. Também se espera, com isso, lograr a prisão de um maior número de integrantes do grupo criminoso, ou mesmo a obtenção da prova contra superiores hierárquicos na associação, os quais raramente se expõem em práticas delituosas. (Eduardo Araújo da Silva, Crime organizado..., ob. cit., p. 93). Deve-se notar, no entanto, que, sob o aspecto ético, este é um meio de investigação de prova de legitimidade bastante discutível, uma vez que, conforme assevera Antonio Magalhães Gomes Filho, "quer pelo aspecto ético, quer pelo ângulo prático, o que deve preponderar nessas situações é exatamente o contrário, ou seja, o interesse na prevenção do delito, evitando-se a consumação de atentados contra a vida, a integridade física, a saúde pública etc, em lugar de se aguardar o melhor momento para a colheita de provas de fatos já perpetrados”. (Antonio Magalhães Gomes Filho, Também em matéria processual provoca inquietação a Lei Anti-Crime Organizado. Boletim IBCCrim, São Paulo, n. 13, fev./1994. No mesmo sentido: Sérgio Marcos de Moraes Pitombo, Prisão temporária e crise urbana. Revista dos Tribunais. São Paulo, ano 75, vol. 603, jan./1986, p. 297; Roberto Delmanto Junior, As modalidades de prisão provisória e seu prazo de duração. Rio de Janeiro / São Paulo: Renovar, 2001, p. 108; Luiz Flávio Gomes e Raúl Cervini, Crime organizado..., ob. cit., p. 118). 
Tendo em vista o estudo - supra - da terminologia da prova, é certo afirmar que as novas técnicas de investigação criadas pelas leis de combate ao crime organizado - e, de maneira específica, a infiltração de agentes, objeto deste trabalho - configuram meios de pesquisa ou de investigação de prova.

De fato, a infiltração de agentes é um procedimento regulamentado por nosso ordenamento jurídico, com o objetivo de obter elementos de prova; não sendo, no entanto, em si, fonte de conhecimento. Ainda, é um procedimento extraprocessual e desprovido de contraditório no momento em que se desenrola, sendo efetuada por policiais. Corresponde, assim, plenamente, à definição estabelecida de meio de investigação de provas. 


\section{CAPÍTULO 3 - INFILTRAÇÃO POLICIAL}

\subsection{Antecedentes históricos.}

A infiltração de agentes tem sua origem ligada ao período do absolutismo francês, mormente à época do Rei Luís XIV ${ }^{257}$, o qual, com o objetivo de fortalecer ainda mais o Ancien Régime, criou a figura do chamado agent provocateur $^{258}$ - "delatores"259 ou, segundo Manuel Augusto Alves Meireis, "os primeiros agentes provocadores da história européia". ${ }^{260}$

Tais "agentes provocadores" eram contratados pela polícia parisiense, no final do século XVIII ${ }^{261}$, e tinham a função de descobrir, no seio da sociedade, quais eram os inimigos políticos do rei, para então denunciá-los em troca de favores. $^{262}$ A polícia fazia distinção entre aqueles que trabalhavam encobertos, clandestinamente - os quais recebiam o nome de observateurs -, e aqueles que eram contratados abertamente, os quais eram apelidados de mouches, sous-inspecteurs, commis ou préposés. ${ }^{263}$ Dentre os contratados, estavam presos que trocavam a liberdade por cooperação com a polícia; e até mesmo pessoas de nível social mais elevado, que ficavam incumbidas de se infiltrar em locais freqüentados pela alta sociedade. ${ }^{264}$

Primeiramente, o "delator" limitava a observar a conduta alheia para, após, levá-la ao conhecimento das autoridades; contudo, com o passar do

\footnotetext{
${ }^{257}$ Eduardo Araújo da Silva, Crime organizado..., ob. cit. p. 87. Note-se que há autores que situam o primeiro aparecimento do agente infiltrado já na Bíblia, no Gênesis (III, 1-7), e outros que apontam seu surgimento na antiguidade grega, nas fábulas de Esopo (Esopo, III, fábula V, Aesopus et petulans). (Mario Daniel Montoya, Informantes y técnicas de investigación encubiertas. Buenos Aires: Ad-Hoc, 2001, p. 39).

258 Isabel Oneto, O agente infiltrado - contributo para a compreensão do regime jurídico das acções encobertas. Coimbra: Coimbra Editora, 2005.

${ }^{259}$ Eduardo Araújo da Silva, Crime organizado..., ob. cit. p. 87.

${ }^{260}$ Manuel Augusto Alves Meireis, O regime das provas obtidas pelo agente provocador em processo penal. Coimbra: Coimbra Editora, 1999, p. 20.

${ }^{261}$ Manuel Augusto Alves Meireis, O regime..., ob. cit., p. 20.

${ }^{262}$ Eduardo Araújo da Silva, Crime organizado..., ob. cit. p. 87.

${ }^{263}$ Manuel Augusto Alves Meireis, O regime..., ob. cit., p. 20.

${ }^{264}$ Manuel Augusto Alves Meireis, O regime..., ob. cit., p. 21.
} 
tempo, notou-se que a mera vigilância não era suficiente para neutralizar a oposição ao regime, evoluindo a atividade de espionagem, assim, para verdadeira provocação das condutas consideradas ilícitas. ${ }^{265}$

A prática do agent provocateur foi usada, também em outros países nessa mesma época. Na Espanha, ele foi empregado em grande medida, em especial durante o período da Inquisição, para a busca de manifestações supostamente "heréticas", dentro do ponto de vista da Igreja Católica. ${ }^{266}$ Também no Reino Unido, usava-se de informantes na obtenção de provas incriminatórias. Em troca de informações e capturas de criminosos, pagava-se uma recompensa ao informante; prática que perdurou durante todo o século XIX. ${ }^{267}$

Assim, é possível notar que, embora hoje - como se verá adiante - o agente infiltrado e o agente provocador sejam figuras bem distintas em nosso ordenamento jurídico, sendo a primeira um meio de investigação de prova aceito por nosso Direito, enquanto a segunda é por ele vedada, ambas tem como origem comum o agent provocateur do absolutismo francês.

\subsection{Conceituação e objetivos.}

A infiltração de agentes consiste em um método de investigação de prova por meio do qual um agente, mediante prévia autorização judicial, infiltra-se em uma organização criminosa, simulando a condição de um integrante, com o objetivo de obter informações sobre seu funcionamento. ${ }^{268}$

Nesse sentido, na visão de Claudia B. Moscato de Santamaría, o agente infiltrado é um agente que "hace uma investigación dentro de una organización criminal, muchas veces, bajo una identidad modificada, a fin de tomar

\footnotetext{
${ }^{265}$ Eduardo Araújo da Silva, Crime organizado..., ob. cit. p. 87.

${ }^{266}$ Isabel Oneto, $O$ agente infiltrado..., ob. cit., p. 25.

${ }^{267}$ Isabel Oneto, $O$ agente infiltrado..., ob. cit., p. 24.

${ }^{268}$ Eduardo Araújo da Silva, Crime organizado..., ob. cit. p. 86.
} 
conocimiento de la comisión de delitos, su preparación e informar sobre dichas circunstancias para así proceder a su descubrimiento, em algunos casos se encuentra autorizado tambíen a participar de la actividad ilícita”. ${ }^{269}$

Manuel Monteiro Guedes Valente, Manuel João Alves e Fernando Gonçalves, por sua vez, definem o infiltrado como o agente que "actue sob o controlo da Polícia Judiciária que, com ocultação da sua qualidade e identidade, e com o fim de obter provas para a incriminação do suspeito, ou suspeitos, ganha a sua confiança pessoal, para melhor o observar, em ordem a obter informações relativas às actividades criminosas de que é suspeito e provas contra ele(s), com as finalidades exclusivas de prevenção ou repressão criminal, sem contudo o(s) determinar à prática de novos crimes". 270

Para Marcelo Batlouni Mendroni, o agente infiltrado é aquele que faz "infiltrar-se no seio da organização criminosa, passando a integrá-la como se criminoso fosse - na verdade, como se um novo integrante fosse. Agindo assim, penetrando no organismo e participando das atividades diárias, das conversas, problemas e decisões, como também por vezes de situações concretas, ele passa a ter condições de melhor compreendê-la para melhor combatê-la através do repasse de informações às autoridades". 271

Para Antonio Scarance Fernandes, por fim, a infiltração de agentes consiste, em suma, no "ingresso de alguém em uma organização criminosa, com ocultação de sua identidade, objetivando descobrir os seus membros, principalmente os de atuação mais relevante na estrutura daquela organização, $e$ colher elementos para a prova de suas infrações. $O$ fato de alguém penetrar na organização, agindo como se a ela pertencesse, permite-lhe conhecer o seu funcionamento e possibilita o acesso a informações e dados relevantes". 272

\footnotetext{
${ }^{269}$ Claudia B. Moscato de Santamaria, El agente encubierto en el Estado de Derecho. Buenos Aires: La Ley, 2000 , p. 01.

${ }^{270}$ Manuel Monteiro Guedes Valente, Manuel João Alves e Fernando Gonçalves, O novo regime jurídico do agente infiltrado. Coimbra: Almedina, 2001, p. 37.

${ }^{271}$ Marcelo Batlouni Mendroni, Crime organizado..., ob. cit., p. 54.

${ }^{272}$ Antonio Scarance Fernandes, O equilíbrio na repressão..., ob. cit., p. 18.
} 
Fernando Gascón Inchausti define a natureza jurídica deste meio de investigação de prova como sendo "una diligencia de investigación admisible em el marco del proceso penal de un Estado de Derecho como el nuestro, siempre que esté legalmente prevista y la adopte de forma motivada um Juez em presencia de indicios suficientes de criminalidad, considerándola como adequada, necesaria y proporcionada a la lyz de las circunstancias del caso concreto". ${ }^{273}$

No Brasil, esse agente é sempre um policial, enquanto que em outros países, como se verá, pode ser também um funcionário público com funções administrativas, ou até mesmo um particular.

$\mathrm{O}$ agente infiltrado, então, se introduz em uma organização criminosa, ou seja, penetra nas suas estruturas organizacionais, assumindo a qualidade de seu "integrante". ${ }^{274}$ A sua integração à organização pode se dar em qualquer de seus níveis, sendo certo que quanto mais alto o nível que o agente alcançar, mais significativa serão as informações que pode obter. ${ }^{275}$

Mario Daniel Montoya descreve as atividades do agente infiltrado da seguinte maneira: "Las operaciones encubiertas incluyen desde una simple compra de narcóticos hasta la más sofisticada creación tendiente a enfrentar a una compleja organización que se mueve a nivel mundial. Donde el hombre que trabaja no solamente debe asemejarse al hombre comum, al drogadicto típico sino también a um financista, a um banquero, con uma cobertura que abarca, desde la forma de vida que debe llevar en lo que hace a sus propriedades, vehículos, residencias, veraniegas, cuentas bancarias, etc., para acercarse a lo más alto de las organizaciones con las cuales tiene que luchar, a fin de no desentonar en el médio em el que se manejará, por cuanto ello le puede costar la vida. Sendebe tener em cuenta que el hombre que actúa en forma encubierta há sido debidamente entrenado, que es um experto no solamente como investigador, sino que también debe moverse com una identidad distinta, que abarca los diversos aspectos de su vida de relación, que tiene datos personales ficticios que comprenden distintos hechos que se extienden desde su

\footnotetext{
${ }^{273}$ Fernando Gascón Inchausti, Infiltración policial y agente encubierto. Granada: Comares, 2001, p. 143.

${ }^{274}$ Carlos Enrique Edwards, El arrepentido, el agente encubierto y la entrega vigilada. Modificación a la ley de estupefacientes. Análisis de la ley 24.424. Buenos Aires: Ad-Hoc, 1996, p. 78.

${ }^{275}$ Carlos Enrique Edwards, El arrepentido..., ob. cit., p. 78.
} 
nacimiento al dia en que entre en una operación, en la cual todos los detalles tienen que ser observados cuidadosamente. Sin olvidar que deve vivir lejos de su familia, de sus conocidos y de todo aquello que lo ligue a su vida de todos los dias, a fin de que la cobertura no sea descubierta. Documentación, propriedades, forma de vida, vecindario, etc., todo ello adquiere una significación especial en determinados ambientes". 276

Os objetivos do agente, uma vez infiltrado na organização criminosa, concentram-se na identificação, neutralização e destruição desta última ${ }^{277}$; bem como na obtenção de elementos de prova que podem vir a ser úteis em eventual persecução penal contra seus integrantes.

Tais fins podem ser alcançados porque, conforme sustenta Rafael Pacheco, "uma vez infiltrado e freqüentando o mesmo ambiente da organização criminosa, os agentes são capazes de presenciar, em primeiro plano, discussões e decisões tomadas por figuras-chave do grupo criminoso. Essas discussões freqüentes relatam crimes consumados ou resultam no planejamento e cometimento de novos crimes. É aqui que se espera estar o agente infiltrado, posto a observar o desenvolvimento dos fatos de forma sempre adequada aos fins da persecução penal provendo abundante informação sobre o esquema e funcionamento da organização". ${ }^{278}$

Dessa forma, a grande vantagem da infiltração policial consiste na possibilidade - mais ampla do que qualquer outro meio de investigação de provas existente em nosso ordenamento jurídico jamais criou - de contato direto e rotineiro entre os policiais e os investigados, propiciando, dentre outros elementos, o aprendizado sobre a função desempenhada na estrutura do grupo e a identificação das fontes dos recursos utilizados pela organização. ${ }^{279}$ Conforme sustenta Marcelo Batlouni Mendroni, “as vantagens que podem advir desse mecanismo processual são evidentes: fatos criminosos não esclarecidos podem ser desvelados, modus operandi, nomes principalmente dos 'cabeças' da organização, nomes de 'testas-de-ferro', bens, planos

\footnotetext{
${ }^{276}$ Mario Daniel Montoya, Informantes..., ob. cit., p. 30.

${ }^{277}$ Rafael Pacheco, Crime organizado..., ob. cit., p. 108.

${ }^{278}$ Rafael Pacheco, Crime organizado..., ob. cit., p. 109.

${ }^{279}$ Rafael Pacheco, Crime organizado..., ob. cit., p. 109.
} 
de execução de crimes, agentes públicos envolvidos, nomes de empresas e outros mecanismos utilizados para a lavagem de dinheiro, etc”. 280

Ainda, a razão pela qual a infiltração de agentes pode alcançar resultados mais satisfatórios do que os demais métodos de investigação de provas é que o sucesso das organizações criminosas depende em enorme medida do segredo a respeito do desenrolar de suas atividades e da identidade de seus membros ${ }^{281}$ - o que enseja, inclusive, como visto, grandes esforços por parte das referidas organizações no sentido de manter-se em sigilo -, o que torna o acesso a essas informações extremamente difícil. O agente infiltrado seria, assim, uma das formas mais eficazes de obter tais informações.

\subsubsection{As modalidades de infiltração.}

As infiltrações policiais podem assumir diversas modalidades, a critério do fim que procuram alcançar. Dependendo do grau de envolvimento do agente no meio criminoso e da duração da operação, podem ser divididas em light cover e deep cover. ${ }^{282}$

As primeiras, infiltrações tidas como mais "leves" e menos arriscadas, caracterizam-se por não durarem mais de seis meses e exigirem um menor grau de experiência, planejamento e supervisão por parte do agente - o qual mantém sua identidade e sua posição na estrutura policial. O objetivo desse tipo de infiltração é, em geral, preciso, resumindo-se a uma única transação ou um só encontro para a obtenção de informações, e não exigem do agente a permanência contínua no meio criminoso $^{283} \cdot 284$

\footnotetext{
${ }^{280}$ Marcelo Batlouni Mendroni, Crime organizado..., ob. cit., p. 54.

${ }^{281}$ Rafael Pacheco, Crime organizado..., ob. cit., p. 108.

${ }^{282}$ Isabel Oneto, $O$ agente infiltrado..., ob. cit., p. 81.

${ }^{283}$ Isabel Oneto, $O$ agente infiltrado..., ob. cit., p. 81.

${ }^{284}$ É possível subdividir as operações light cover em seis modalidades, cujas formas e aplicação variam bastante ao redor do mundo. São elas: a decoy operation (ou operation leurre), na qual o agente assume o
} 
Já as operações denominadas deep cover revelam-se mais "profundas", apresentando duração maior e exigindo do agente a total submersão no meio a ser investigado. É nesse tipo de infiltração que os agentes recebem identidades falsas, chegando, inclusive, a cortar os contatos com seu meio social e familiar originário. Esse é o tipo de infiltração mais arriscada para o agente, é o mais propenso a deixar-lhe seqüelas, sejam físicas, sejam psicológicas ${ }^{285} \cdot{ }^{286}$

\subsubsection{A prática de condutas típicas por parte do agente infiltrado e a possibilidade de sua responsabilização penal.}

A prática de condutas típicas por parte do policial que se infiltra em organizações criminosas é inevitável. Embora existam entendimentos em contrário $^{287}$, acreditamos ser de suma importância, para que o infiltrado possa se

papel de vítima em potencial, para que outros policiais possam efetuar a prisão no momento em que o infiltrado for atacado pelo investigado; a pseudo-achat, na qual o policial apresenta-se como comprador dos produtos ilíticos; a pseudo-vente, onde o agente demonstra ser vendedor de tais produtos; o flashroll, em que o infiltrado exibe quantias de dinheiro a fim de convencer os vendedores da mercadoria ilícita a "fechar o negócio"; a livraison surveillée, ou entrega vigiada, que consiste em vigiar o transporte, em determinado território, de mercadoria ilícita, retardando-se a interpelação dos investigados a fim de deter os responsáveis por ela; e livraison controlée, semelhante à livraison surveillée, mas na qual os próprios policiais transportam a mercadoria, responsabilizando-se pela entrega. (Isabel Oneto, $O$ agente infiltrado..., ob. cit., pp. 82-83). Note-se que, no Brasil, a livraison surveillée, ou entrega vigiada, consiste, na realidade, não uma modalidade de infiltração policial, mas um outro meio de investigação de prova para os crimes relacionados à criminalidade organizada: á a ação controlada, regulada de maneira independente em nosso ordenamento, pelo artigo $2^{\circ}$, inciso II, da Lei $\mathrm{n}$. 9.034/95.

${ }^{285}$ Isabel Oneto, $O$ agente infiltrado..., ob. cit., pp. 81-82.

${ }^{286}$ Também ressalvando-se diferenças regionais, pode-se dividir as operações deep cover, genericamente, em: sting operation (na qual um agente, sob falsa identidade, monta uma empresa ou um estabelecimento comercial, alardeando que compra mercadoria ilícita ou roubada, com o objetivo de atrair para ele os investigados), honey-pot operation (em que o infiltrado abre um bar ou outro comércio, com a intenção de o transformar em um centro de encontros da criminalidade organizada), buy-bust oparation (técnica de infiltração na qual o agente, aos poucos, adquire pequenas quantidades de drogas ou outros produtos ilícitos, sem que seu fornecedor seja detido, para assim efetuar sua inserção no meio criminoso; e efetua a prisão do investigado apenas no momento em que efetua a compra de uma quantidade maior de produtos ilegais), e, finalmente, a infiltration de réseaux ou de groupes (operação de infiltração mais ou menos longa de caráter genérico, em que o agente se infiltra no meio criminoso para assim recolher informações e provas sobre a preparação de crimes ou sua consumação). (Isabel Oneto, $O$ agente infiltrado..., ob. cit., pp. 83-84).

${ }^{287}$ Rafael Pacheco acredita que não é estritamente necessário que o agente cometa delitos para que possa permanecer infiltrado em uma organização criminosa. "Levando-se em conta que a maioria das organizações criminosas está em situação pré-mafiosa, empresarial, torna-se factível integrar-se em sua estrutura sem o cometimento obrigatório de crimes. O cometimento de crime como uma prova de fidelidade, 
caracterizar plenamente como membro da organização investigada, que ele participe das atividades por esta desenvolvidas. Caso o policial se recuse a participar das diligências propostas pelos investigados, poderá levantar suspeitas sobre a sua identidade, o que pode vir a ser extremamente arriscado. Assim, para preservar a sua condição de infiltrado - e, conseqüentemente, a própria investigação -, o agente necessariamente precisará, mais cedo ou mais tarde, tomar parte em alguma empreitada delitiva $^{288}{ }^{289}$

Essa face da infiltração de agentes - a necessidade do cometimento de delitos para a obtenção de provas que não poderiam, de outro modo, ser conseguidas - tornou-se logo um problema de difícil solução. Como regulamentar a atuação dos agentes estatais que tinham a participação em uma organização criminosa como parte de seu trabalho diário?

A legislação brasileira não traz qualquer disposição relacionada à punibilidade dos crimes cometidos pelo agente policial na condição de infiltrado. A tarefa de achar uma solução para a sua impunidade ficou, então, a cargo da doutrina e da jurisprudência.

Dessa forma, parte da doutrina entende que a melhor solução para a questão está no terreno das excludentes de antijuricidade, classificando a ação dos policiais infiltrados como estrito cumprimento do dever legal. ${ }^{290} \mathrm{O}$ estrito

em regra, são praticadas por organizações criminosas do tipo tradicional, mafiosas ou por aqueles grupos de extrema violência. Portanto, nem sempre será necessário praticar crimes, pois pode o infiltrado atuar em diversos níveis da organização, inclusive em uma de suas faces lícitas, pela qual poderá cumprir seu dever sem a necessidade imperiosa de delinqüir”. (Rafael Pacheco, Crime organizado..., ob. cit., p. 126). Embora essa seja uma posição doutrinária interessante, cremos não ser totalmente condizente com a realidade, uma vez que a necessidade da prática de delitos pelos infiltrados, na maior parte das vezes, não se dá apenas como um "ritual de iniciação" na organização, mas sim como uma rotina diária que deve ser enfrentada.

288 Afima Isabel Oneto: “o agente infiltrado, durante o seu trabalho, depara-se freqüentemente com uma situação ambígua, uma vez que tem de inserir-se num meio criminoso sem poder adoptar o comportamento delituoso dos seus actores. Aliás, assinala que tal situação nem sempre é realizável, pois é precisamente com a prática de alguns delitos que o agente infiltrado ganha a confiança dos restantes membros do grupo". (Isabel Oneto, $O$ agente infiltrado..., ob. cit., p. 81).

${ }^{289}$ Note-se que, em alguns casos, notadamente nos Estados Unidos da América, as organizações criminosas têm se valido exatamente da relutância - legal ou moral - dos agentes infiltrados em cometer crimes para criar "contra-medidas" à infiltração. Em geral, exige-se que o novo membro da organização passe por um "rito de inicialização", o qual geralmente compreende a prática de um homicídio. (Isabel Oneto, O agente infiltrado..., ob. cit., p. 96).

${ }^{290}$ Rafael Pacheco, Crime organizado..., ob. cit., p. 131. 
cumprimento do dever legal é uma causa de exclusão da ilicitude do delito ${ }^{291}$ (ou causa de justificação, segundo parte da doutrina ${ }^{292}$ ) que compreende os deveres de intervenção do funcionário público na esfera privada para assegurar o cumprimento da lei ou de ordens superiores da administração pública, que podem determinar a realização justificada de tipos legais, como a coação, a privação de liberdade, a violação de domicílio e a lesão corporal. ${ }^{293}$ A situação justificante de tal causa de exclusão de ilicitude é a existência de lei em sentido amplo (lei, decreto ou regulamento, por exemplo) ou de ordem de superior hierárquico, qualquer das duas hipóteses determinantes de dever vinculantes da conduta do funcionário público. ${ }^{294}$ No Código Penal Brasileiro, tal instituto encontra-se previsto no artigo 23, inciso III. ${ }^{295}$

Há forte oposição a esta idéia, no entanto, no sentido de que não se pode conceber um policial que tenha o dever de delinqüir. ${ }^{296}$ Ainda, outro grave problema da utilização desta excludente para isentar de pena o agente infiltrado é que, por sua natureza, ela se comunica aos co-autores e partícipes do crime ${ }^{297}$, ou seja, caso aplicada, alcançaria também, necessariamente, os integrantes reais da organização

${ }^{291}$ Celso Delmanto, Roberto Delmanto, Roberto Delmanto Junior e Fabio M. de Almeida Delmanto, Código Penal Comentado. São Paulo: Renovar, 2007, p. 91; e Rogério Greco, Curso de Direito Penal - Parte geral, volume 1. Rio de Janeiro: Impetus, 2007, p. 370; entre outros.

${ }^{292}$ Juarez Cirino dos Santos, A moderna teoria do fato punível. Rio de Janeiro: Freitas Bastos, 2000, p. 187; e Carlos Enrique Edwards, El arrepentido..., ob. cit., p. 87; entre outros.

293 Juarez Cirino dos Santos, A moderna teoria..., ob. cit., p. 187.

${ }^{294}$ Juarez Cirino dos Santos, A moderna teoria..., ob. cit., pp. 187-188.

295 “Art. 23. Não há crime quando o agente pratica o fato:

(...)

III - em estrito cumprimento de dever legal ou no exercício regular de direito".

${ }^{296}$ Rafael Pacheco, Crime organizado..., ob. cit., p. 131. Nesse sentido, sustenta José Antônio Pinheiro de Aranha Filho: "No caso do agente infiltrado, não há como afirmar que o seu ato criminoso, ainda que necessário para o sucesso da operação, seja uma dessas excludentes de ilicitude; pois os limites fixados tanto pelo art. $2^{\circ}$, inciso $V$, da Lei 9.034/95, assim como pelo art. 33, inciso I, da Lei 10.409/02 limitam sua açao à infiltração e apuração de infrações penais, jamais em praticar tais ações penais. Não permitem sequer implicitamente que o agente pratique qualquer delito. Por outro lado, a obrigação de agir do agente policial será sempre a de impedir que o cometimento de crimes ou ainda de apurá-los, nos termos propostos pelos respectivos dispositivos de lei, até porque seria um absurdo a lei obrigar o agente policial ao cometimento de crimes”. (José Antônio Pinheiro de Aranha Filho, Implicações..., ob. cit..).

${ }^{297}$ Celso Delmanto, Roberto Delmanto, Roberto Delmanto Junior e Fabio M. de Almeida Delmanto, Código Penal..., ob. cit., p. 92. 
criminosa que participaram do delito com o infiltrado - os quais acabariam por ser isentados de qualquer responsabilidade penal relacionada àquele ato. ${ }^{298}$

Outra corrente doutrinária defende a isenção de responsabilidade criminal dos policiais infiltrados com fulcro nas causas supralegais de excludentes de culpabilidade, na modalidade da inexigibilidade de conduta diversa. Considerando-se a teoria tripartite ou tripartida do delito adotada por nosso Código Penal vigente ${ }^{299}$, se subtraída a culpabilidade dos elementos do delito, este resta descaracterizado. A culpabilidade, por sua vez, tem como pressuposto a possibilidade de exigir-se conduta diversa, conforme a teoria finalista adotada por nosso Código Penal. Logo, se, no caso concreto, não se pode exigir do agente conduta diversa da praticada, então não há que se falar em culpabilidade; o que torna a sua conduta impunível. Nesse sentido, sustenta Francisco de Assis Toledo: “A inexigibilidade de outra conduta é, pois, a primeira e mais importante causa de exclusão da culpabilidade. E constitui verdadeiro princípio de direito penal", 300

Essa idéia se justifica uma vez que, caso o infiltrado decida não participar da empreitada criminosa, pode acabar por comprometer a finalidade da infiltração ou mesmo colocar em risco a própria vida - ou seja, não haveria, para ele, outra alternativa senão a prática do delito. ${ }^{301}$

Uma terceira corrente doutrinária defende a atipicidade da ação do agente infiltrado, por total ausência de dolo - elemento constitutivo do tipo ${ }^{302}$ , uma vez que o policial, ao agir, não tem a intenção de praticar o crime, apenas

\footnotetext{
${ }^{298}$ Carlos Enrique Edwards, El arrepentido..., ob. cit., p. 89.

${ }^{299}$ A doutrina atualmente majoritária no Brasil - e adotada por nosso Código Penal vigente - entende crime como sendo um fato típico, antijurídico e culpável. É a chamada teoria tripartida ou tripartite do conceito de crime, segundo a qual, para que se entenda uma determinada conduta como crime, é necessário que se verifiquem, no caso concreto, a existência da tipicidade, da antijuridicidade e da culpabilidade. (Guilherme de Souza Nucci, Código penal comentado. São Paulo: Revista dos Tribunais, 2006, p. 118).

${ }^{300}$ Francisco de Assis Toledo, Princípios básicos de direito penal. São Paulo: Saraiva, 1994, p. 328.

${ }^{301}$ Rafael Pacheco, Crime organizado..., ob. cit., p. 132.

302 Jorge de Figueiredo Dias, Direito Penal - Parte geral - tomoI. São Paulo: Revista dos Tribunais/Coimbra: Coimbra Editora, 2007, p. 348.
} 
pretende auxiliar a investigação e a obtenção de provas a respeito para eventual persecução penal dos integrantes da organização criminosa. ${ }^{303}$

Por fim, tem-se a última - e maior - parcela da doutrina, que defende a escusa absolutória como forma de não responsabilização das condutas típicas praticadas pelos agentes infiltrados, como opção de política criminal. ${ }^{304}$ Esta é a opção preferida pela maior parte das legislações que adota a infiltração como técnica de investigação. $^{305}$

A escusa absolutória é uma causa pessoal de exclusão da aplicação da pena, por questões de política criminal, tendo um caráter eminentemente individual. Reconhece-se que, embora o ato praticado pelo agente infiltrado seja típico, antijurídico e culpável, não lhe será aplicada a pena por uma questão de política criminal, a qual é a própria essência da utilização da infiltração de agentes como meio de investigação de provas. Note-se que, sendo a escusa absolutória, como visto, uma causa pessoal $e$ individual de exclusão de pena, a mesma não se estende aos integrantes reais da organização criminosa que tenham participado do delito juntamente com o infiltrado, os quais receberão a pena correspondente à sua participação criminosa. ${ }^{306}$

No entanto, seja qual for a justificativa jurídica empregada para isentar o agente infiltrado de punição, há que se considerar que não ele não pode ser autorizado a cometer qualquer tipo de infração penal. Devem existir limites claros à sua atuação delitiva, tanto devido à moralidade do instituto - o qual, afinal, representa o Estado - quanto - e principalmente - para garantir a segurança dos bens jurídicos tutelados pela legislação penal.

\footnotetext{
${ }^{303}$ Rafael Pacheco, Crime organizado..., ob. cit., p. 133.

${ }^{304}$ Rafael Pacheco, Crime organizado..., ob. cit., p. 133.

${ }^{305}$ A esse respeito, ver o Capítulo 4 deste trabalho (Direito Comparado).

${ }^{306}$ Carlos Enrique Edwards, El arrepentido..., ob. cit., p. 88. Existem, contudo, críticas a esta solução encontrada pela doutrina, no sentido de que "a impunidade do agente policial não pode cingir-se apenas a uma razão de política criminal, sob pena de seu ato criminoso caracterizar-se como um 'nada' jurídico, dando espaço à arbitrariedade”. José Antônio Pinheiro Aranha Filho, Implicações..., ob. cit..)
} 


\subsubsection{O dilema ético.}

Muito embora a infiltração de agentes possa ser considerada um método, pelo menos em princípio, eficaz para a investigação de provas nos delitos relacionados à criminalidade organizada, inúmeros são os questionamentos suscitados com a sua inclusão em nosso ordenamento jurídico, mormente os de caráter ético - o que não nos causa nenhuma surpresa, visto que se trata de um instituto que se propõe a elucidar crimes ao mesmo tempo em que se arrisca a cometê-los.

Sabe-se que, durante a sua atuação como infiltrado, o agente pode defrontar com a necessidade de realizar condutas delitivas, com o objetivo de ganhar a confiança dos demais integrantes da organização delitiva ou, até mesmo, no cumprimento de "ordens" dos mesmos. ${ }^{307}$ Nesses casos, pode ser imperativo para o agente efetuar tais condutas a fim tanto de preservar sua integridade física quanto de garantir o sucesso da operação e investigação.

Assim, por um lado, não é exagero afirmar que o Estado se vale de um meio imoral no combate à criminalidade, uma vez que o agente infiltrado se utiliza da mentira e da traição como meios para desbaratar organizações criminosas. ${ }^{308}$ Por vezes, como visto ${ }^{309}$, o infiltrado pode chegar a cometer delitos no desempenho de sua função - o que equivaleria a dizer que o Estado, por meio de seu agente, estaria delinqüindo. Combate-se, assim, um delito com outro delito, colocando-se o Estado ao mesmo nível dos criminosos que procura punir. ${ }^{310}$

No entanto, ao criar normas que tenham o objetivo de investigar delitos graves, como a delinqüência organizada, o Estado deve levar em conta os princípios legados à moralidade e à ética no direito. ${ }^{311}$ Conforme ensina Ada

\footnotetext{
${ }^{307}$ Carlos Enrique Edwards, El arrepentido..., ob. cit., p. 80.

${ }^{308}$ Carlos Enrique Edwards, El arrepentido..., ob. cit., p. 54.

${ }^{309}$ Item 3.2.2, supra.

${ }^{310}$ Carlos Enrique Edwards, El arrepentido..., ob. cit., p. 54.

${ }^{311}$ Mariângela Lopes Neistein, $O$ agente infiltrado..., ob. cit., p. 71.
} 
Pellegrini Grinover, "a luta contra a criminalidade deve servir-se de um instrumento ético, que respeite a dignidade e a inviolabilidade humanas". ${ }^{312}$

De fato, nossa Constituição da República prevê, em seu artigo 37, caput $^{313}$, que a Administração Pública atue obedecendo aos princípios da legalidade, impessoalidade, moralidade, publicidade e eficiência. ${ }^{314}$ É o chamado princípio da moralidade administrativa. ${ }^{315}$ Em respeito a esse princípio, o Estado deve valer-se sempre de meios morais no combate e prevenção à pratica de delitos, quaisquer que seja a sua gravidade ${ }^{316}$; sendo imprescindível que o administrador público exerça sua missão à luz da ética, da razoabilidade, do respeito ao próximo, da justiça, e, sobretudo, da honestidade. ${ }^{317}$ A adequação legal do instituto da infiltração policial, sob esse aspecto, é imprescindível. Nesse sentido, afirmam Manuel Monteiro Guedes Valente, Manuel João Alves e Fernando Gonçalves: "Um Estado de Direito democrático, dotado de um processo penal de estrutura acusatória temperado pelo princípio da acusação, teria inerentemente de defender e impor aos operadores judiciários a obrigatoriedade de actuarem legal e eticamente. Esta dialética tem o seu fundamento no respeito da dignidade humana”. 318

No caso do agente infiltrado, pode-se dizer que, ainda que se trate de uma figura prevista em lei, sua atividade, sob certo aspecto, fere diretamente o princípio da moralidade administrativa ${ }^{319}$, uma vez que sua atuação exige, no mais das vezes, que o agente cometa delitos a fim de preservar o segredo de sua identidade.

312 Ada Pellegrini Grinover, Interrogatório do réu e direito ao silêncio. Revista Ciência Penal, n. 1, ano III, 1976, p. 28.

313 “Art. 37. A administração pública direta e indireta de qualquer dos Poderes da União, dos Estados, do Distrito Federal e dos Municípios obedecerá aos princípios de legalidade, impessoalidade, moralidade, publicidade e eficiência".

${ }^{314}$ Mariângela Lopes Neistein, $O$ agente infiltrado..., ob. cit., p. 73.

$315 \mathrm{O}$ mesmo princípio encontra-se previsto em diversas legislações federais relacionadas à Administração Pública, tais como as Leis n. 1.079/50 e 9.784/99. (Mariângela Lopes Neistein, $O$ agente infiltrado..., ob. cit., p. 73).

${ }^{316}$ Mariângela Lopes Neistein, O agente infiltrado..., ob. cit., p. 73.

${ }^{317}$ Uadi Lammêgo Bulos, Curso de Direito Constitucional. São Paulo: Saraiva, 2007, p. 795. Acrescenta o autor: "O quid caracterizador da moralidade administrativa, por certo, está na aplicação justa, honesta e razoável da lei”. (Uadi Lammêgo Bulos, Curso..., ob. cit., p. 796).

${ }^{318}$ Manuel Monteiro Guedes Valente, Manuel João Alves e Fernando Gonçalves, O agente infiltrado versus o agente provocador. Os princípios do processo penal. In: Lei e crime. Coimbra: Almedina, 2001, p. 144.

${ }^{319}$ Mariângela Lopes Neistein, $O$ agente infiltrado..., ob. cit., p. 73. 
Nesse sentido, sustenta Mariângela Lopes Neistein: "a utilização do agente infiltrado evidencia que o Estado se vale de um meio imoral na repressão de crimes graves, tais como o tráfico de drogas e o crime organizado, já que o agente infiltrado utiliza-se da mentira e da traição para operar meios de descoberta de indícios desses delitos. Inclusive, o próprio agente infiltrado pode vir a cometer delitos no desempenho de sua função, a fim de ganhar a confiança dos criminosos. Isso significa que o Estado, por meio do agente infiltrado, estaria cometendo um delito. Seria uma forma de combater um crime com outro crime, colocando-se no mesmo nível dos delinqüentes". 320

Conforme crítica feita por Antonio Magalhães Gomes Filho, "trata-se, como se sabe, de procedimento cuja legitimidade ética e jurídica é cada vez mais contestada em sociedades mais avançadas, como a alemã e a norteamericana, pois é incompatível com a reputação e a dignidade da Justiça Penal que seus agentes se prestem a envolver-se com as mesmas práticas delituosas que se propõem a combater; e mesmo as eventuais provas resultantes dessas operações terão sido conseguidas através de instigação, simulação ou outros meios enganosos, $e$ portanto de duvidosa validade. De outro lado, não constitui heresia supor que, entre nós, sobretudo pela notória má remuneração atribuída aos agentes policiais, tais expedientes encerrariam um sério risco de atraírem para a criminalidade pessoas que, por sua ligação com as estruturas oficiais, teriam excepcionais condições para se integrarem às mesmas associações criminosas, incrementando suas atividades ilegais.". 321

Juarez Cirino dos Santos, por sua vez, afirma que "a figura do agente infiltrado em quadrilhas ou organizações elou associações criminosas, como procedimento de investigação e de formação de provas, com a inevitável participação do representante do poder em ações criminosas comuns, infringe o princípio ético que proíbe o uso de meios imorais pelo Estado para reduzir a impunidade”. 322

Luiz Flávio Borges D’Urso também critica a figura em questão: “A grande preocupação nesse caso é que o agente policial eventualmente

\footnotetext{
${ }^{320}$ Mariângela Lopes Neistein, $O$ agente infiltrado..., ob. cit., p. 74.

${ }^{321}$ Antonio Magalhães Gomes Filho, Também em matéria processual..., ob. cit.

${ }^{322}$ Juarez Cirino dos Santos, Crime organizado. Revista Brasileira de Ciências Criminais. São Paulo: Revista dos Tribunais, n. 42, jan.-mar./2003, p. 224.
} 
poderá conseguir autorização para se infiltrar na quadrilha e dela fazer parte, praticando crimes, objetivando colher elementos de interesse da investigação, mas, excepcionalmente, se obrar criminosamente, permanecerá cometendo crimes sob o manto da lei que lhe dará verdadeiro 'salvo conduto' para tal, e, caso surpreendido, invocará a autorização da infiltração. Temo este dispositivo, que poderá inaugurar uma categoria de agentes policiais acima da lei, autorizados por esta a praticar crimes, tudo objetivando punir autores dessas infrações penais. (...) Ora, como admitir que poderemos autorizar um agente policial assaltar, para o fim de se prender e punir assaltantes? O Estado não estaria caindo num contra-senso? Essas questões se colocam para o plano prático. Há que se meditar sobre o desvio de condita do 'infiltrado', que poderá trazer mais males do que contribuição efetiva à investigação criminal, sem falar no altíssimo risco de vida que o agente policial infiltrado correrá",323.

Nesse mesmo sentido, sustentam Manuel Monteiro Guedes Valente, Manuel João Alves e Fernando Gonçalves: "a figura do agente infiltrado consubstancia, intrinsecamente em si mesma, uma técnica de investigação de moral duvidosa, uma vez que é o próprio suspeito que, actuando em erro sobre a qualidade do funcionário de investigação criminal, produz, involuntariamente, a prova da sua própria condenação”. ${ }^{324}$ Complementam, ainda, os mesmos autores: “[o Estado] não se pode arrogar de todos os meios e métodos ao seu dispor para perseguir os infratores. Os fins não podem e, muito mesmo, devem num Estado de direito democrático justificar os meios e métodos. Quem se arroga da moral para executar a perseguição não pode socorrer-se de meios desonestos, de meios em nada deontológicos, embora apregoados como eficazes, mas nem sempre eficientes, para 'apanhar' alguns infractores, ${ }^{325}{ }^{326}$

\footnotetext{
${ }^{323}$ Luiz Flávio Borges D’urso, Lei nova autoriza infiltração de policiais em quadrilhas. Artigo disponível no endereço eletrônico www.ibccrim.com.br em agosto de 2005.

324 Manuel Monteiro Guedes Valente, Manuel João Alves e Fernando Gonçalves, O novo regime jurídico..., ob. cit., p. 83.

325 Manuel Monteiro Guedes Valente, Manuel João Alves e Fernando Gonçalves, O novo regime jurídico..., ob. cit., p. 83.

${ }^{326}$ Em sentido contrário, Rafael Pacheco: “Crê-se precipitada a atribuição de uma moral duvidosa atribuída pelos autores, uma vez que, a menos no Brasil, a infiltração, igualmente a outros institutos que restringem garantias e direitos constitucionais, está submetida ao controle e amparada por ordem de um juiz competente. (...) Diferentemente dos informantes e delatores arrependidos, os agentes infiltrados
} 
Por outro lado, porém, deve-se atentar para a eficácia do agente infiltrado como meio de investigação de provas - mormente nos delitos relacionados à criminalidade organizada, como se propõe no ordenamento jurídico brasileiro. Fato é que o crime organizado, como já se viu, é enormemente complexo, ramificado e, como o próprio nome diz, organizado, sendo necessários meios diferenciados e altamente eficazes para que seja possível a obtenção de provas para a persecução penal de seus integrantes. De fato, "o crime organizado adquiriu uma dimensão nunca antes conhecida e é neste contexto que deve ser encarada a adopção, nos diversos ordenamentos jurídicos, da figura do agente infiltrado”. 327

Está-se, portanto, diante de valores conflitantes: a moralidade e a licitude dos meios de investigação de provas nos delitos relacionados à criminalidade organizada, e a eficácia dessa investigação de provas. ${ }^{328}$

No Brasil - e, como se verá ${ }^{329}$, em nos demais países do mundo, à exceção de Luxemburgo - o legislador fez sua opção pela eficácia, permitindo a uso do agente infiltrado como meio de investigação de provas e regulamentando sua atuação em lei. Tal escolha foi feita, sem dúvida, devido à explosão da criminalidade organizada e do tráfico de drogas ao redor do mundo, o que motivou a regulamentação legal do agente infiltrado como opção de política criminal. $^{330}$

Nesse sentido, afirma Mariângela Lopes Neistein: " $O$ agente infiltrado tem se justificado devido ao avanço dos meios utilizados pelos membros das organizações criminosas e da dificuldade em se conseguir elementos a

representam o Estado e devem assim fazê-lo de forma a não subverter a própria lei que pretendem e devem defender”. (Rafael Pacheco, Crime organizado..., ob. cit., pp. 110-111).

${ }^{327}$ Isabel Oneto, $O$ agente infiltrado..., ob. cit., p. 47.

${ }^{328}$ Carlos Enrique Edwards, El arrepentido..., ob. cit., p. 54.

${ }^{329}$ Capítulo 4, infra.

${ }^{330}$ Carlos Enrique Edwards, El arrepentido..., ob. cit., p. 54. Interessante notar, ainda, a posição de Isaac Sabbá Guimarães, que defende que o agente infiltrado deve ser usado apenas para observar a atuação dos investigados, sem tomar parte no cometimento de delitos: "a infiltração de agentes não os autoriza à prática delituosa (...). O infiltrado, antes de induzir outrem à ação delituosa, ou tomar parte dela na condição de coautor ou partícipe, ou mesmo praticar delito autônomo, (v.g., comprar entorpecentes para fins de uso), limitar-se-á ao objetivo de colher informações sobre operações ilícitas, as quais serão repassadas à autoridade que preside as investigações com o fim de traçar a tática de persecução e elucidação do crime”.(Isaac Sabbá Guimarães, O agente infiltrado na investigação das associações criminosas. Boletim IBCCrim. São Paulo, v. 10, n. 117, ago./2002, pp. 12-13). 
respeito de infrações por meio delas perpetradas, que ultrapassam as condições hodiernas de investigação pelo Estado. Assim, por questão de política criminal, passou-se a admitir, em algumas legislações, tal figura, considerando-se este o único meio de se descobrir e desmantelar referidas organizações, que tanto perigo geram à sociedade". 331

\subsection{A tipificação legal no direito brasileiro.}

A figura do agente infiltrado foi proposta pela primeira vez no ordenamento brasileiro pelo Projeto de Lei n. 3.516/1989, em seu artigo $2^{\circ}$, inciso I, com a seguinte redação original:

“Art. 20. I - a infiltração de agentes da polícia especializada em quadrilhas ou bandos, vedada qualquer co-participação delituosa, exceção feita ao disposto no art. 288 do Decreto-lei n. 2.848, de 7 de dezembro de 1940 - Código penal, de cuja ação se preexclui, no caso a antijuridicidade”.

Depreende-se de sua leitura - a despeito da redação tortuosa $^{332}$ - que a intenção dos legisladores era possibilitar a utilização da infiltração

\footnotetext{
${ }^{331}$ Mariângela Lopes Neistein, $O$ agente infiltrado..., ob. cit., p. 47. Contudo, alguns doutrinadores discutem, ainda, a eficácia do agente infiltrado como meio de investigação de provas, a exemplo de Omar Gabriel Orsi: "Em efecto, dado el avance operado em el campo de la tecnología de la información, parece cuanto menos llamativo que uma organización de amplio espectro deba ser rastreada apelando al viejo y peligroso recurso del infiltrado: em el mundo de hoy el âmbito de la clandestinidad parece reposar más en lo que no se desea ver que en la improbable quimera de permanecer en uma absoluta opacidad". O autor sugere que, o invés de se utilizar a infiltração de agentes - método de alto risco -, os mesmos resultados poderiam ser obtidos por meio das interceptações e rastreamentos telefônicos; da quebra de sigilo bancário e financeiro e do rastreamento da entrada e saída dos investigados de seus países. Assim, prossegue o autor, "ante estas herramientas se relativizam los aportes que puede efectuar el agente encubierto, máxime si tenemos em cuenta que aquélla prueba es judicialmente segura y menos manipulable. (Omar Gabriel Orsi, Sistema penal y crimen organizado - Estrategias de aprehensión y criminalización del conflicto. Buenos Aires: Editores del Puerto, 2007, p. 154). Entendemos, no entanto, que, em alguns casos, e devido às estratégias supra mencionadas das organizações criminosas de ocultação de provas, a infiltração policial pode ser mais eficaz do que qualquer outro meio de investigação, existindo provas, de fato, que apenas poderão ser obtidas com o emprego dos agentes infiltrados.
}

${ }^{332}$ Valdir Sznick, Crime organizado - comentários. São Paulo: Leud, 1997, p. 223. 
policial em qualquer das fases da persecução criminal, quando se tratasse de ações praticadas por quadrilhas ou bandos. ${ }^{333}$

O referido Projeto de Lei converteu-se posteriormente na Lei n. 9.034/1995, tendo sofrido, no entanto, veto parcial do então Presidente da República Fernando Henrique Cardoso. Um dos excertos objeto de veto foi justamente o inciso em questão, versando sobre a infiltração de agentes, sob a justificativa de que tal dispositivo contrariava o interesse público, uma vez que não contemplava a necessidade de autorização prévia do Poder Judiciário para a efetivação da medida em questão; bem como concedia autorização legal expressa para que os agentes infiltrados cometessem um crime, ficando desde logo excluída a antijuridicidade, o que afrontava os princípios adotados pela sistemática do Código Penal. ${ }^{334}$

${ }^{333}$ Rafael Pacheco, Crime organizado..., ob. cit., p. 111.

${ }^{334}$ Assim lê a mensagem de veto parcial ao Projeto de lei n. 3.516, de 1989 (n. 62/90 no Senado Federal), correspondente à Lei n. 9.034/95:

"Senhor Presidente do Senado Federal,

Comunico a Vossa Excelência que, nos termos do parágrafo $1^{o}$ do artigo 66 da Constituição Federal, decidi vetar parcialmente o Projeto de Lei n. 3.516, de 1989 (n. 62/90 no Senado Federal), que "dispõe sobre a utilização de meios operacionais para a prevenção e repressão de ações praticadas por organizações criminosas".

É o seguinte o teor do dispositivo ora vetado por contrariar o interesse público:

'Art.

I - a infiltração de agentes da polícia especializada em quadrilhas ou bandos, vedada qualquer coparticipação delituosa, exceção feita ao disposto no art. 288 do Decreto-lei $n$. 2.848, de 7 de dezembro de 1940 - Código penal, de cuja ação se preexclui, no caso a antijuridicidade;

O Ministério da Justiça assim se manifestou sobre o assunto:

' $O$ inciso I do art. $2^{\circ}$, nos termos em que foi aprovado, contraria o interesse público, uma vez que permite que o agente policial, independentemente de autorização do Poder Judiciário, se infiltre em quadrilhas ou bandos para a investigação de crime organizado.

Essa redação, como se pode observar, difere da original, fruto dos estudos elaborados por uma subcomissão, presidida pelo Deputado Miro Teixeira, que tinha como relator o Deputado Michel Temer, criada no âmbito da Comissão de Constituição e Justiça e Redação, que, de forma mais apropriada, condicionava a infiltração de agentes de polícia especializada em organização criminosa à prévia autorização judicial.

Além do mais, deve-se salientar que o dispositivo em exame concede expressa autorização legal para que o agente infiltrado cometa crime, preexcluída, no caso, a antijuridicidade, o que afronta os princípios adotados pela sistemática do Código Penal.

Em assim sendo, parece-nos que o inciso I do art. $2^{o}$ deve merecer o veto do Excelentíssimo Senhor Presidente da República, nos termos do art. 66, parágrafo $1^{\circ}$, da Constituição Federal, ressaltando, 
No ano de 2000, contudo, uma forte onda de violência urbana assolava o país, mormente o estado do Rio de Janeiro, ligada principalmente ao tráfico de drogas. Como resposta à forte pressão da população por respostas do Poder Executivo à crise no setor da segurança pública, o mesmo Presidente da República Fernando Henrique Cardoso lançou o Plano Nacional de Segurança Pública, o qual propunha, entre outras medidas, a introdução da infiltração de agentes como meio de investigação de provas. ${ }^{335}$

Foi apresentado, então, o Projeto de Lei n. 3.275/2000, para o qual foi solicitado trâmite em regime de urgência constitucional. ${ }^{336}$ Este novo Projeto foi aprovado sem restrições, sendo então introduzida em nosso ordenamento jurídico a Lei n. 10.217, de 2001, que acrescentou o inciso $\mathrm{V}$ ao artigo $2^{\circ}$ da Lei $\mathrm{n}$. 9.034/95, o qual finalmente incorporou a infiltração de agentes como meio de investigação de prova nos delitos relacionados à criminalidade organizada ao nosso corpo legislativo, nos seguintes termos:

“Art. $2^{\circ}$. Em qualquer fase de persecução criminal são permitidos, sem prejuízo dos já previstos em lei, os seguintes procedimentos de investigação e formação de provas:

$$
\text { (...) }
$$

$V$ - infiltração por agentes de polícia ou de inteligência, em tarefas de investigação, constituída pelos órgãos especializados pertinentes, mediante circunstanciada autorização judicial"

(Destaque acrescentado. $^{337}$

\footnotetext{
contudo, que este Ministério, posteriormente, encaminhará proposta regulamentando a matéria constante do dispositivo acima mencionado'.

Estas, Senhor Presidente, as razões que me levaram a vetar em parte o projeto em causa, as quais ora submeto à clevada apreciação dos Senhores Membros do Congresso Nacional".

${ }^{335}$ Rafael Pacheco, Crime organizado..., ob. cit., p. 112.

${ }^{336}$ Rafael Pacheco, Crime organizado..., ob. cit., p. 113.

${ }^{337}$ De se notar que, posteriormente, a Lei $\mathrm{n}^{\circ} 10.409$, de 2002, também tratou desse instituto, em seu artigo 33, inciso I; sendo que suas disposições a respeito dessa matéria foram repetidas na Lei $n^{\circ} 11.343$, de 23 de agosto de 2006, em seu artigo 53, I, in verbis:
} 
Nota-se que a redação ora vigente, com o intuito de regulamentar a infiltração de agentes policiais em organizações criminosas, procurou corrigir as falhas que ensejaram o veto à proposta anterior, exigindo a autorização prévia da autoridade judiciária competente como forma de assegurar o controle judicial sobre essa atividade; e excluindo do texto legal a "autorização" para que os infiltrados cometessem o crime tipificado pelo artigo 288 do Código Penal (quadrilha ou bando).

Contudo, o dispositivo vigente segue com graves falhas, por não determinar um procedimento próprio para o processamento da infiltração, bem como por deixar de prever quem possuiria a legitimidade para requerê-la, qual seu prazo de duração, se ela pode ou não ser renovada de ofício pelo juiz ou mesmo se é possível sua renovação, se as informações obtidas pelo policial infiltrado devem ser relatadas ao Magistrado ou ao Ministério Público, e como se dá a participação deste órgão. ${ }^{338}$ Tampouco dispôs a nova lei quanto aos limites que deverão ser observados pelo agente policial quando da infiltração autorizada judicialmente. ${ }^{339}$ Em verdade, apenas dois pontos estão regulados no texto legal em análise: quem pode infiltrar-se e quem deve autorizar a infiltração. ${ }^{340}$

É interessante perceber ainda que, enquanto em boa parte do mundo o agente infiltrado apenas é admitido para a investigação de determinados tipos de crimes (algumas legislações, como a alemã, apresentam um rol de crimes para cuja investigação é aceita a infiltração de agentes; outras prevêem o método já em leis

“Art. 53. Em qualquer fase da persecução criminal relativa aos crimes previstos nesta Lei, são permitidos, além dos previstos em lei, mediante autorização judicial e ouvido o Ministério Público, os seguintes procedimentos investigatórios:

I - a infiltração por agentes de polícia, em tarefas de investigação, constituída pelos órgã̃es especializados pertinentes".

${ }^{338}$ Eduardo Araújo da Silva, Crime organizado..., ob. cit. p. 87.

${ }^{339}$ Eduardo Araújo da Silva, Crime organizado..., ob. cit. p. 89. Para assegurar o respeito às garantias do investigado ante a precariedade da regulamentação legal da medida em questão, Eduardo Araújo da Silva sugere que se empregue para a infiltração policial, por analogia e no que couber, o procedimento previsto na Lei n. 9.296/1996, que disciplina a interceptação das comunicações telefônicas e sinais telemáticos, visto que esta Lei "reflete a moderna concepção do princípio da proporcionalidade em relação a matéria que igualmente pode resultar em restrição ao direito à privacidade”. (Eduardo Araújo da Silva, Crime organizado..., ob. cit. pp. 87-88). Note-se que esta sugestão, ainda que pertinente, deve ser encarada de forma meramente paliativa, pois não dispensa a elaboração - urgente - de lei para regular as infiltrações policiais, levando em conta todas as peculiaridades inerentes à matéria.

${ }^{340}$ Antonio Scarance Fernandes, O equilíbrio..., ob. cit., p. 252. 
específicas, como é o caso da Argentina, na qual o agente infiltrado aparece regulamentado na Ley de Estupefacientes, devendo ser empregado apenas na investigação de delitos relacionados ao tráfico de $\operatorname{drogas}^{341}$ ), a legislação brasileira não faz qualquer restrição aos tipos de delitos que podem ser investigados por esse meio desde que tenha sido ele cometido por grupos organizados, ou esteja de alguma forma a eles relacionados. No entanto, não se pode empregar tal técnica para a investigação de delitos desconexos do crime organizado, sob nenhuma hipótese, uma vez que se trata de um procedimento investigatório excepcional ${ }^{342}$, não se justificando nenhum $\operatorname{alargamento}^{343} \cdot 344$

Por fim, não traz a lei brasileira qualquer resposta satisfatória à questão dos crimes que possam vir a ser cometidos pelos agentes enquanto infiltrados nas organizações criminosas - ponto nevrálgico na matéria, vez que, como se verá, a sua permanência no seio das organizações sem o cometimento de nenhum delito é praticamente impossível. Nesse sentido, sustenta Antonio Scarance Fernandes: "O agente infiltrado realiza atividade de grande risco e, por isso, atua de forma oculta para que não seja descoberto. Ingressando na organização, pode ser levado ao cometimento de infrações a fim de ser por ela acolhido, adquirir prestígio e chegar aos seus líderes. Por outro lado, participará das vidas de outras pessoas nem sempre ligadas às atividades delituosas, como parentes dos membros da organização.

\footnotetext{
${ }^{341}$ Ver, infra, Capítulo 4.

${ }^{342}$ Nesse sentido, a lição de Marta Gómez de Liaño Fonseca-Herrero: "El agente encubierto merece el calificatico de medio de control extraordinário, al conllevar una alteración de principios constitucionales básicos y una fuerte restricción de derechos fundamentales, razones ambas determinantes de que su empleo quede sometido al cumplimiento de estrictos requisitos legales, paliativos de los riesgos para las garantias procesales vigentes en un Estado de Derecho”. (Marta Gómez de Liaño Fonseca-Herrero, Criminalidad organizada..., ob. cit., p. 129).

${ }^{343}$ Alberto Silva Franco, Leis Penais Especiais..., ob. cit., p. 584.

${ }^{344}$ Note-se que, por força do disposto no artigo 53, inciso I, da Lei 11.343/2006 (Nova Lei de Drogas), o emprego do agente infiltrado como método de investigação de provas é admitido também nos delitos previstos nessa lei, como se lê:
}

"Art. 53. Em qualquer fase da persecução criminal relativa aos crimes previstos nesta Lei, são permitidos, além dos previstos em lei, mediante autorização judicial e ouvido o Ministério Público, os seguintes procedimentos investigatórios:

I - a infiltração por agentes de polícia, em tarefas de investigação, constituída pelos órgãos especializados pertinentes".

No entanto, deixaremos de abordar este aspecto da infiltração de agentes por entender que tal análise ultrapassa o escopo deste trabalho, cujo objetivo é fazer a análise da referida figura à luz da criminalidade organizada. 
Importante, por tudo isso, que a sua atuação seja regulada, especificando-se o que pode ou não fazer o agente infiltrado, como prevêem outras legislações". 345

De fato, apesar das melhorias patentes em relação ao projeto original, é certo dizer que o dispositivo legal que regula o agente infiltrado no Brasil permanece "deveras obscuro, senão lacunoso, já que deixa de delimitar objetivamente, em nítida violação ao princípio da legalidade, a atuação do agente infiltrado, bem como a natureza jurídica de seus atos na organização criminosa”. ${ }^{346}$

\subsubsection{Os policiais que podem atuar como agentes infiltrados.}

No Brasil, resta claro, por força do artigo $2^{\circ}$, inciso $\mathrm{V}$, da Lei n. 9.034/95, que apenas policiais podem exercer a função de agentes infiltrados. ${ }^{347}$ No entanto, é necessário que se atente para o fato de que nem todos os tipos de policiais podem se infiltrar em organizações criminosas.

$\mathrm{O}$ inciso $\mathrm{V}$ do artigo $2^{\circ}$ da Lei n. 9.034/95, como visto, autoriza a infiltração policial nos seguintes termos:

“Artigo $2^{o}$. V-infiltração, por agentes de polícia ou de inteligência, em tarefas de investigação, constituída pelos órgãos especializados pertinentes, mediante circunstanciada autorização judicial”.

(Destaque acrescentado.)

Assim, o texto legal dá a entender que as atividades de infiltração seriam atribuição tanto dos policiais - sem, no entanto, especificar quais tipos de policiais - quanto dos agentes de inteligência.

${ }^{345}$ Antonio Scarance Fernandes, O equilíbrio..., ob. cit., p. 252.

${ }^{346}$ José Antônio Pinheiro Aranha Filho, Implicações sobre a figura do agente infiltrado. Artigo disponível no endereço eletrônico: www.ibccrim.org.br, em 17 de junho de 2003.

${ }^{347}$ Note-se que em outros países, tais como Argentina, Portugal e Espanha, pode-se ter como infiltrados indivíduos alheios aos quadros da polícia, bastando, para que possam assumir tal posição, que se subordinem ao poder do Estado. 
No entanto, o artigo 144 de nossa Constituição Federal atribui e delimita expressamente as atribuições das diferentes instituições policiais brasileiras, conferindo inequivocamente às Polícias Civis e à Federal a função de apurar o cometimento de infrações penais, como se vê:

“Art. 144. A segurança pública, dever do Estado, direito e responsabilidade de todos, é exercida para a preservação da ordem pública e da incolumidade das pessoas e do patrimônio, através dos seguintes órgãos:

I - polícia federal;

II - polícia rodoviária federal;

III - polícia ferroviária federal;

IV - polícias civis;

$V$ - polícias militares e corpos de bombeiros militares.

$\S 1^{\circ} \underline{\text { A polícia federal, }}$ instituída por lei como órgão permanente, organizado $e$ mantido pela União e estruturado em carreira, destina-se a:

I - apurar infrações penais contra a ordem política e social ou em detrimento de bens, serviços e interesses da União ou de suas entidades autárquicas e empresas públicas, assim como outras infrações cuja prática tenha repercussão interestadual ou internacional e exija repressão uniforme, segundo se dispuser em lei;

II - prevenir e reprimir o tráfico ilícito de entorpecentes e drogas afins, o contrabando e o descaminho, sem prejuízo da ação fazendária e de outros órgãos públicos nas respectivas áreas de competência;

III - exercer as funções de polícia marítima, aeroportuária e de fronteiras;

IV - exercer, com exclusividade, as funções de polícia judiciária da União. 
$\S 2^{\circ}$ A polícia rodoviária federal, órgão permanente, organizado e mantido pela União e estruturado em carreira, destina-se, na forma da lei, ao patrulhamento ostensivo das rodovias federais.

$\S 3^{\circ}$ A polícia ferroviária federal, órgão permanente, organizado e mantido pela União e estruturado em carreira, destina-se, na forma da lei, ao patrulhamento ostensivo das ferrovias federais.

$\S 4^{o}$ - às polícias civis, dirigidas por delegados de polícia de carreira, incumbem, ressalvada a competência da União, as funções de polícia judiciária e a apuração de infrações penais, exceto as militares.

$\S 5^{\circ}$ - às polícias militares cabem a polícia ostensiva e a preservação da ordem pública; aos corpos de bombeiros militares, além das atribuições definidas em lei, incumbe a execução de atividades de defesa civil.

$\S 6^{\circ}$ - As polícias militares e corpos de bombeiros militares, forças auxiliares $e$ reserva do Exército, subordinam-se, juntamente com as polícias civis, aos Governadores dos Estados, do Distrito Federal e dos Territórios.

$\S 7^{o}$ - A lei disciplinará a organização e o funcionamento dos órgãos responsáveis pela segurança pública, de maneira a garantir a eficiência de suas atividades.

$\S 8^{o}$ - Os Municípios poderão constituir guardas municipais destinadas à proteção de seus bens, serviços e instalações, conforme dispuser a lei.

$\S 9^{\circ}$ A remuneração dos servidores policiais integrantes dos órgãos relacionados neste artigo será fixada na forma do $\S 4^{\circ}$ do art. $39 ”$.

(Destaques acrescentados).

Dessa forma, de acordo com o dispositivo constitucional supra, é às Polícias Civis e Federal que cabe a função de investigação dos delitos, ficando a seu cargo a busca de provas. Devem ser apenas essas instituições policiais, portanto, que podem ter seus agentes (policiais civis e federais) infiltrados, durante a investigação de um delito ligado ao crime organizado. Vale dizer, apenas os policiais operantes nas polícias de caráter repressivo é que podem atuar como infiltrados, uma 
vez que apenas estes têm autorização para investigar o cometimento de delitos. Não podem ser infiltrados os agentes das polícias preventivas, pois sua função não é investigar, mas apenas prevenir a prática de crimes. ${ }^{348}$

Assim sendo, como reforça Mariângela Lopes Neistein, "não se pode considerar como agente infiltrado todo e qualquer agente de polícia, mas somente aqueles que são membros da polícia repressiva, que seriam os policiais federais e civis - não abrangendo os militares, rodoviários, ferroviários, membros da polícia ostensiva, etc”. 349

Por outro lado, os chamados agentes de inteligência membros da Agência Brasileira de Inteligência $(A B I N)^{350}$ - não têm por função colher provas para o processo penal, visto que a $\mathrm{ABIN}$ não tem função de polícia. ${ }^{351}$ Seu objetivo é fornecer ao governo informações necessárias para que se mantenham seguras a ação governamental e a segurança da sociedade e do Estado. ${ }^{352}$ Nesse sentido, assevera Mariângela Lepes Neistein: "os serviços de inteligência não têm como objetivo a busca de provas ou indícios a serem utilizadas em inquéritos policiais ou processos criminais, mas a produção de um conhecimento que permita a tomada de decisões estratégicas para auxílio do governo e segurança do Estado. Os elementos buscados e obtidos pelos agentes da ABIN terão a finalidade de auxiliar no

\footnotetext{
${ }^{348}$ Mariângela Lopes Neistein, $O$ agente infiltrado..., ob. cit., p. 99.

${ }^{349}$ Mariângela Lopes Neistein, $O$ agente infiltrado..., ob. cit., p. 101.

350 A Agência Brasileira de Inteligência (ABIN) é um dos braços do Sistema Brasileiro de Inteligência (SISBIN), o qual é composto, ainda, por membros oriundos de diferentes órgãos governamentais, tais como o Ministério da Saúde e o Ministério da Previdência. (Rafael Pacheco, Crime organizado..., ob. cit., p. 116). A origem da ABIN, originalmente denominada "Atividade de Informações", remonta ao advento do Conselho de Defesa Nacional (Decreto n. 17.999, de 29 de novembro de 1927), o qual tinha por objetivo a obtenção de informações vinculadas a interesses estratégicos de segurança do Estado. Durante o período da ditadura militar, que perdurou dos anos 1960 até meados dos anos 1980 no Brasil, a atividade de Inteligência brasileira passou a denominar-se Sistema Nacional de Informações (SNI), o qual, por intermédio de seu departamento conhecido como DOI-CODI, foi responsável pela censura, tortura, perseguições e assassinatos contra os membros dos movimentos de resistência que desafiavam o governo. Em 7 de dezembro de 1999, foram criados os órgãos de Inteligência atualmente existentes, a ABIN e o SISBIN, por meio da sanção presidencial da Lei n. 9.883/1999. (Mariângela Lopes Neistein, O agente infiltrado..., ob. cit., pp. 102-103).

${ }^{351}$ Mariângela Lopes Neistein, O agente infiltrado..., ob. cit., p. 103.

${ }^{352}$ Decreto n. 4.376/2002, artigo $2^{\circ}$ : "Para efeitos deste decreto, entende-se como inteligência a atividade e análise de dados e informações e de produção e difusão de conhecimento, dentro e fora do território nacional, relativos a fatos e situações de imediata ou potencial influência sobre o processo decisório, a ação governamental, a salvaguarda e a segurança da sociedade e do Estado”.
} 
planejamento, avaliação e realização de estratégias que almejam a combater ameaças contra o governo". 353

Note-se que tampouco podem os agentes de inteligência realizar colheita de provas, haja visto tal função ser privativa dos Policiais Civis, por força do disposto no artigo 144 da Constituição da República, supra.

Pode-se afirmar, assim, que a disposição do artigo $2^{\circ}$, inciso V, da Lei n. 9.034/95, é de inconstitucional, por atribuir aos agentes de inteligência função colidente com os preceitos constitucionais ${ }^{354}$, uma vez que a Constituição da República determina expressamente que a atividade investigatória criminal cabe aos membros das polícias repressivas. ${ }^{355}$ Nesse sentido, sustenta Rafael Pacheco: "parece-nos ser de duvidosa constitucionalidade a permissão contida na Lei 10.217/01, que prevê a atuação de agentes de inteligência como infiltrados, na medida em que, para tais agentes, não são em regra cometidas funções de polícia judiciária e, desse modo, não estão legitimados a coletar provas voltadas às futuras utilizações em processo penal, única causa legítima capaz de fundamentar as violações à intimidade $e$ outros direitos fundamentais que implicam a atividade de infiltração". 356

\subsubsection{As recomendações da Convenção de Palermo em relação à infiltração de agentes.}

O artigo 20 da Convenção de Palermo prevê a utilização meios especiais de investigação de provas, dentre os quais figura a infiltração de agentes; e traz algumas poucas recomendações em relação ao seu uso no combate ao crime organizado:

\footnotetext{
${ }^{353}$ Mariângela Lopes Neistein, $O$ agente infiltrado..., ob. cit., p. 105.

${ }^{354}$ Rafael Pacheco, Crime organizado..., ob. cit., p. 115.

${ }^{355}$ Mariângela Lopes Neistein, $O$ agente infiltrado..., ob. cit., p. 102.

${ }^{356}$ Rafael Pacheco, Crime organizado..., ob. cit., p. 115.
} 
"Article 20. 1. If permitted by the basic principles of its domestic legal system, each State Party shall, within its possibilities and under the conditions prescribed by its domestic law, take the necessary measures to allow for the appropriate use of controlled delivery and, where it deems appropriate, for the use of other special investigative techniques, such as electronic or other forms or surveillance and undercover operations, by its competent authorities in its territory for the purpose of effectively combating organized crime.

2. For the purpose of investigating the offences covered by this Convention, State Parties are encouraged to conclude, when necessary, appropriate bilateral or multilateral agreements or arrangements for using such special investigative techniques in the context of cooperation at the international level. Such agreements or arrangements shall be concluded and implemented in full compliance with the principle of sovereign equality of States and shall be carried out strictly in accordance with the terms of those agreements or arrangements.

3. In the absence of an agreement or arrangement as set forth in paragraph 2 of this article, decisions to use such special investigative techniques at the international level shall be made on a case-by-case basis and may, when necessary, take into consideration financial arrangements and understandings with respect to the exercise of jurisdiction by the States Parties concerned.

4. Decisions to use controlled delivery ar the international level may, with the consent of the States Parties concerned, include methods such as intercepting and allowing the goods to continue intact or be removed or replaced in whole or in part".

(Destaque acrescentado).

No entanto, como já se frisou supra $^{357}$, e como se percebe no artigo ora mencionado, a intenção da referida Convenção não é introduzir no ordenamento

${ }^{357}$ Item 1.6.4, supra. 
jurídico de seus países signatários conceitos e medidas "pré-fabricadas", e sim introduzir conceitos e determinações para que, a partir de tais bases, estes países possam fabricar seus textos legais. Assim, o dispositivo em questão não regulamenta o emprego do agente infiltrado, mas determina que o Brasil crie normas para que este meio de investigação seja implementado e utilizado no país, com vistas ao combate efetivo ao crime organizado ${ }^{358}$.

Como diretrizes, a Convenção propõe que o uso do agente infiltrado seja regulamentado de forma a não entrar em conflito com o ordenamento jurídico interno brasileiro, e que seja sempre precedido de autorização da autoridade competente. $\mathrm{O}$ documento autoriza, ainda, o estabelecimento de alianças bi ou multilaterais entre países para que a infiltração possa ocorrer em diversos Estados, desde que respeitadas as soberanias nacionais.

\subsection{Agente infiltrado e agente provocador.}

O agente infiltrado, enquanto imerso na organização criminosa, deve limitar-se à mera observação das atividades desta, participando, quando necessário, de atividades delituosas que já se encontravam em curso quando de sua chegada; ou, ao máximo, de condutas típicas sugeridas e elaboradas inteiramente pelos reais membros da organização. A idéia das atividades delituosas deve sempre partir dos investigados, e jamais do investigador; ou, em outras palavras, " $a$ interferência do agente não pode ser essencial nem determinar a prática do crime”. ${ }^{359}$

Caso, porventura, o agente extrapole os limites de sua função, vindo a influir decisivamente no comportamento dos investigados, e alterandolhes a predisposição acerca do cometimento de crimes $^{360}$, passa-se a encarar a conduta do policial não mais sob a perspectiva de agente infiltrado, mas, sim, de agente provocador.

\footnotetext{
${ }^{358}$ Rodrigo Carneiro Gomes, O crime organizado..., ob. cit., p. 203.

${ }^{359}$ Isabel Oneto, $O$ agente infitlrado..., ob. cit., p. 27.

${ }^{360}$ Isabel Oneto considera que "a actuação de um agente encoberto ultrapassa os limites do admissível quando alguém está de tal forma em seu poder que não pode deixar de se vergar à sua vontade”. (Isabel Oneto, $O$ agente infitlrado..., ob. cit., p. 98).
} 
$\mathrm{O}$ agente provocador é aquele que "induce a outro a cometer un delito, o contribuye a su ejecución com actos de autoria o de auxílio, lo que lleva a cabo sin intención de lesionar ni poner em peligro el bien jurídico afectado ni lograr satisfacer ningún interes personal, sino simplemente por el hecho de lograr que el provocado pueda ser sancionado por su conducta”. ${ }^{361}$ Sua atuação é indesejada, pois vicia a manifestação da vontade do agente, de forma a induzi-lo à prática de um ato. ${ }^{362}$ Conforme ensina Rogério Lauria Tucci, "resta, então, desvirtuada a atuação delitiva desenvolvida pelo infrator, nos seus aspectos fundamentais, consubstanciados na espontaneidade do querer, na exclusividade da ação criminosa e na autenticidade do fato tido como típico pela legislação penal material”363. Ainda, lembram Manuel Monteiro Guedes Valente, Manuel João Alves e Fernando Gonçalves: “caso o agente infiltrado passe a provocador, actua contrariamente aos princípios e às normas próprias de um Estado de direito democrático e inerentes a um processo penal de estrutura acusatória temperado pelo princípio da investigação". 364

Carlos Enrique Edwards assim diferencia o agente infiltrado do provocador: "mientras el agente provocador es quien instiga a outro a cometer un determinado delito, el agente encubierto es quien se infiltra en uma organización para obtener información, no instigando a la comisión de ningún tipo de delito. Em el primer caso, hay uma actitud activa por parte del provocador que incita a cometer el delito; mientras que en el supuesto del agente encubierto, su postura es pasiva, recepcionando información. Aqui radica justamente el limite que separa el empleo de una técnica investigativa eficaz, como el agente encubierto, de la utilización

\footnotetext{
${ }^{361}$ Mario Daniel Montoya, Informantes..., ob. cit., p. 41. Prossegue o autor: "La actuación del agente provocador se caracteriza por la estructura contradictoria en que se desarrolla su conducta: por uma parte quiere el castigo del delincuente a través de un hecho que com su conduta provoca, pero no desea la lesión del bién jurídico al que va dirigida la acción del provocado. Punto éste que diferencia su actuación de cualquier outro que pudiera participar en el delito a fin de producir su lógica consecuencia. Debemos admitir que em muchos casos el agente provocador solo logra que el autor de um proceder ilícito resulte condenado, lesionando el bién jurídico que la leye protege”. (Mario Daniel Montoya, Informantes..., ob. cit., p. 41).

${ }^{362}$ Roberto Delmanto Junior, As modalidades..., ob. cit., p. 109.

${ }^{363}$ Rogério Lauria Tucci, Persecução penal, prisão e liberdade. São Paulo: Saraiva, 1980, p. 228.

${ }^{364}$ Manuel Monteiro Guedes Valente, Manuel João Alves e Fernando Gonçalves, O novo regime jurídico..., ob. cit., p. 32.
} 
por parte del Estado de medios delictivos, como la isntigación a cometer un delicto, para la posterior detención del instigado". ${ }^{365}$

Note-se que a indução da prática do crime pelo policial torna impossível a efetivação de qualquer tipo de prisão referente a este delito. Isso porque, conforme o entendimento adotado por nossa doutrina e jurisprudência, a interferência do agente provocador na auto-determinação do investigado torna o crime impossível, uma vez que este não se consumaria não fosse a intervenção do agente estatal. De fato, em tais circunstâncias, "a consumação do delito é impossível, tendo-se em vista o fato de não restar ameaçado ou efetivamente ofendido qualquer bem juridicamente tutelado, sem prejuízo de se questionar também o dolo, posto que a vontade do aludido infrator, ou seja, o elemento subjetivo de sua conduta, foi desvirtuada ${ }^{366}$.

Nelson Hungria assim qualifica o ato do investigado eivado de influências por parte do agente policial: "Um crime que, além de astuciosamente sugerido e ensejado ao agente, tem suas conseqüências frustradas por medidas tomadas de antemão, não passa de um crime imaginário. Não há lesão, nem efetiva exposição a perigo, de qualquer interesse público ou privado" ${ }^{367}$ (destaque acrescentado).

Assim, o tipo de prisão em flagrante realizada sob essas circunstâncias - quando o crime apenas se consumou devido à ingerência do agente provocador - recebe o nome de flagrante provocado, o qual é descrito por Rogério Lauria Tucci como "o estado de flagrância delitiva forjado, provocado, forçado, em que se cogita de antepor, propositadamente, um fato orientador da conduta do criminoso. Daí por que esta, ao invés de desenrolar-se espontaneamente, é dirigida à efetuação de determinada infração penal ${ }^{\text {,368 }}$. Nelson Hungria, por sua vez, define o flagrante preparado como a hipótese verificada "quando alguém insidiosamente provoca outrem à prática de um crime e, simultaneamente, toma as providências

\footnotetext{
${ }^{365}$ Carlos Enrique Edwards, El arrepentido..., ob. cit., p. 57.

${ }^{366}$ Roberto Delmanto Junior, As modalidades..., ob. cit., p. 111.

${ }^{367}$ Nelson Hungria, Comentários ao Código Penal, v. 1, t. 2. Rio de Janeiro: Forense, 1955, p. 105.

${ }^{368}$ Rogério Lauria Tucci, Persecução penal..., ob. cit., p. 228.
} 
necessárias para surpreendê-lo na flagrância da execução, que fica, assim, impossibilitada ou frustra",369

Tal entendimento foi adotado pelo Superior Tribunal de Justiça, como se vê da leitura do verbete da Súmula 145:

“Não há crime quando a preparação do flagrante pela polícia torna impossível a sua consumação”.

Dessa forma, fica claro que, nas hipóteses em que o delito apenas é cometido em decorrência da incitação do policial, não é possível a prisão do imputado pura e simplesmente porque não há crime, uma vez que a consumação do delito é impossível. ${ }^{370}$

Esta idéia encontra respaldo, também, na maior parte dos ordenamentos jurídicos estrangeiros. Na Espanha, na década de 1970, surgiu uma corrente jurisprudencial que defendia a punibilidade da provocação policial. De acordo com essa corrente - que encontrou respaldo também em Portugal e em diversos doutrinadores ao redor do mundo-, o agente policial que provocasse um delito seria punido a menos que sua interferência não se mostrasse essencial para o cometimento do delito por parte do investigado; ou seja, não determinasse sua ocorrência, apenas o desvendasse. ${ }^{371}$ Essa tese se baseia na existência de, ao menos, dolo eventual por parte do agente provocador, o qual, de mais a mais, atua como instigador do delito ${ }^{372} \cdot{ }^{373}$

\footnotetext{
${ }^{369}$ Nelson Hungria, Comentários..., ob. cit., p. 103.

370 Nesse sentido, Tales Castelo Branco: "não haverá crime a punir. A ação ardilosa, visando surpreender alguém em flagrante e sujeitá-lo à punição, é que introduziu, desonestamente, o agente ao cometimento do crime, não se justificando a lavratura do auto de prisão em flagrante, nem muito menos a sua manutenção” (Tales Castelo Branco, Da prisão em flagrante. São Paulo: Saraiva, 2001, pp. 190-191).

${ }^{371}$ Isabel Oneto, $O$ agente infitlrado..., ob. cit., p. 27.

${ }^{372}$ Isabel Oneto, $O$ agente infitlrado..., ob. cit., p. 36.

${ }^{373}$ Em sentido contrário a esta tese, Sebastián Soler defende que a intenção do agente provocador "no tiende a la producción de um hecho, sino el descubrimiento de um sujeto como punible”. Assim, "es posible que la intencion del instigador no vaya más allá del comienzo de ejecución, es decir, que el instigador, em realidad, provoque la tentativa sin tener el ánimo de que el hecho se consume. Es el caso del llamado agente provocador, cuyo propósito no tiende a la produción de um hecho, sino el descubrimiento de un sujeto como punible. Es evidente que allí falta la convergência intencional, a que nos hemos referido, como característica real y no fingida de la participación. El agente provocador no responderá como instigador, si el delito no se consuma, por falta de elemento subjetivo punible: así como no hay tentativa de instigación - dice LiszSchimidt - así tampoco hay instigación a tentativa. Si el hecho llega a consumarse, para determinar la punibilidad del agente provocador, deverán aplicarse los princípios del dolo eventual, a fin de decidir si
} 
Os Estados Unidos da América, por sua vez, operaram uma verdadeira revolução na problemática da provocação ao crime. O país criou, no início do século XX, a chamada entrapment defense, mecanismo de proteção ao acusado elaborado com o fim de garantir os direitos dos cidadãos face aos excessos dos agentes infiltrados $^{374}$. Tal mecanismo tem a função de precisar em quais circunstâncias o provocado deve ficar isento de pena por ter atuado sob a provocação de um agente estatal $^{375} \mathrm{e}$, em sua acepção mais comum, se configura na análise da intervenção dos agentes policiais, cujos efeitos no investigado são averiguados em função do seu impacto hipotético sobre o homem médio respeitador da lei ("normally law-abiding person"). ${ }^{376}$

\subsection{A compatibilidade constitucional da infiltração de agentes.}

Sabe-se que o processo penal não pode se desenvolver a qualquer preço. Para que se garanta um processo judicial adequado - e, em última análise, a própria credibilidade e eficácia da justiça -, é necessário que sejam respeitados os direitos fundamentais do investigado. ${ }^{377}$

Assim, e sendo o Brasil um Estado Democrático de Direito - em que tanto o poder de criar as leis quanto o de aplicá-las na persecução penal estão submetidos a uma Lei Maior ${ }^{378}$-, o emprego do agente infiltrado como técnica de

hubo o no convergência intencional. Se el objeto del agente era hacer sufrir la pena al instigadok, es indudable que no habría dasistido de su acción ante la imagen del delito consumado. Por el contrario, se el confidente de la polícia tênia la fundada esperanza de que el delito no ocurriría, y hubiese desistido ante la certeza de su producción, no está em dolo hy, em consecuencia, no es punible como partícipe de um delito doloso”. (Sebastián Soler, Tratado de derecho penal argentino, tomo II. Buenos Aires. TEA, 1992, p. 329).

${ }^{374}$ Isabel Oneto, $O$ agente infitlrado..., ob. cit., pp. 30 e 37.

${ }^{375}$ Mario Daniel Montoya, Informantes..., ob. cit., p. 41.

${ }^{376}$ Isabel Oneto, $O$ agente infitlrado..., ob. cit., p. 44. A entrapment defense será melhor estudada no Item 4.4, infra.

377 Enrique Ruiz Vadillo, Garantías del proceso presupuesto del tratamiento del delincuente. Revista de Política Criminal y Reforma Penal. Espanha: Editoriales de Derecho Reunidas, p. 979.

${ }^{378}$ Luigi Ferrajori, Direito e razão - teoria do garantismo penal. São Paulo: Revista dos Tribunais, 2006, p. 855. 
investigação de prova no processo penal há que respeitar as garantias individuais oferecidas por nossa Constituição da República.

Nesse sentido, afirmam Manuel Monteiro Guedes Valente, Manuel João Alves e Fernando Gonçalves: “as técnicas de obtenção de meios de prova em processo penal têm de promover a materialização dos princípios e dos direitos próprios de um estado de direito democráticos, ou seja, devem materializar o princípio democrático como forma de legitimação do poder". 379

No entanto, em virtude da natureza invasiva da infiltração de agentes, é quase certo que algumas garantias constitucionais serão ofendidas caso se opte por utilizá-la ${ }^{380}$, o que deve ser levado em consideração ao cogitar-se de seu emprego.

\subsubsection{O devido processo legal.}

Para Enrique Bacigalupo, o devido processo legal é sinônimo de um "processo con todas las garantías" 381, ou seja, que se ajusta aos princípios da oficialidade, de legalidade, da oralidade, de imediação, de livre valoração da prova, ao princípio acusatório e ao "in dubio pro reo". ${ }^{382}$ Assim, corresponde a "un conjunto de principios de carácter suprapositivo y supranacional, cuya legitimación es sobre todo histórica, pues proviene como médio de prueba, del sistema de prueba tasada, de la formación de la convicción del juez sobre la base de actas escritas en un procedimiento fuera del control público. Es, como la noción misma de Estado Democrático de Derecho, um concepto prévio a toda regulación jurídico positiva y una

\footnotetext{
${ }^{379}$ Manuel Monteiro Guedes Valente, Manuel João Alves e Fernando Gonçalves, $O$ novo regime jurídico..., ob. cit., p. 30 .

${ }^{380}$ Mariângela Lopes Neistein, O agente infiltrado como meio de investigação. Dissertação de mestrado apresentada à Faculdade de Direito da Universidade de São Paulo. São Paulo: USP, 2006, p. 154.

${ }^{381}$ Enrique Bacigalupo, El debido proceso penal. Buenos Aires: Hammurabi, 2005, p. 13.

${ }^{382}$ Enrique Bacigalupo, El debido proceso penal, ob. cit, pp. 14-15.
} 
referencia reguladora de la interpretación del Derecho vigente". ${ }^{383}$ Seria, por assim dizer, o modelo processual do Estado de Direito. ${ }^{384}$

Em nossa Constituição da República, o devido processo legal aparece como garantia para a proteção dos direitos fundamentais dos indivíduos ${ }^{385}$, estando previsto no artigo $5^{\circ}$, inciso $\mathrm{LIV}^{386}$, e determina a imperiosidade, em nosso Estado de Direito, de: i) um processo legislativo de elaboração de leis previamente definido e regular, acompanhado de razoabilidade e senso de justiça de seus dispositivos, os quais devem estar necessariamente enquadrados nas disposições constitucionais; ii) a aplicação das normas jurídicas, tanto das leis positivadas quanto de qualquer outra expressão do direito, apenas por meio do processo penal; e iii) a assecuração, no processo, da paridade de armas entre as partes que o integram, com vistas à igualdade e ao equilíbrio entre elas. ${ }^{387}$

Dessa forma, o devido processo legal empresta ao processo penal a sua função de jurisdicionalização da pena (nulla poena sine iudicio), uma vez que a sanção penal somente poderá ser aplicada pelos órgãos jurisdicionais por meio de um instrumento adequado - o processo -, o qual deverá, sob pena de nulidade, respeitar todas as garantias previstas em nossa Carta Magna. Joaquim Canuto Mendes de Almeida afirma, nesse sentido, que a legalidade - ou seja, a limitação legal à restrição da liberdade, por meio do devido processo legal - garante a liberdade jurídica do acusado: "A residual liberdade natural, ao adentrar assim o mundo jurídico, deixa de ser meramente natural, transformando-se em liberdade jurídica". ${ }^{388}$

\footnotetext{
${ }^{383}$ Enrique Bacigalupo, El debido proceso penal, ob. cit, p. 13.

${ }^{384}$ Enrique Bacigalupo, El debido proceso penal. Buenos Aires: Hammurabi, 2005, p. 13.

${ }^{385}$ Rogério Lauria Tucci, Direitos e garantias..., ob. cit., pp. 65-66.

386 “Art. $5^{\circ}$ Todos são iguais perante a lei, sem distinção de qualquer natureza, garantindo-se aos brasileiros $e$ aos estrangeiros residentes no País a inviolabilidade do direito à vida, à liberdade, à igualdade, à segurança e à propriedade, nos termos seguintes:

(...)

LIV - ninguém será privado da liberdade ou de seus bens sem o devido processo legal."

${ }^{387}$ Rogério Lauria Tucci, Direitos e garantias..., ob. cit., pp. 63-64.

${ }^{388}$ Joaquim Canuto Mendes de Almeida, A liberdade jurídica no direito e no processo. Estudos jurídicos em homenagem a Vicente Ráo. São Paulo: Resenha Universitária, 1976, p.11.
} 
Note-se que, no processo penal, o conjunto de componentes e corolários formadores do devido processo legal pode receber o nome de devido processo penal ${ }^{389}$, para indicar, com mais rigor, o campo do direito em que atuam suas garantias. ${ }^{390}$

\subsubsection{Princípio do contraditório. O contraditório diferido no tempo.}

Um dos corolários fundamentais do devido processo legal é o princípio do contraditório, previsto por nossa Constituição da República em seu artigo $5^{\circ}$, inciso $\mathrm{LV}^{391}$. Nas palavras de Aury Lopes Jr, ele pode ser “inicialmente tratado como um método de confrontação da prova e comprovação da verdade, fundando-se não mais sobre um juízo potestativo, mas sobre o conflito, disciplinado e ritualizado, entre partes contrapostas: a acusação (expressão do interesse punitivo do Estado) e a defesa (expressão do interesse do acusado [e da sociedade] em ficar livre de acusações infundadas e imune a penas arbitrárias e desproporcionadas". 392

Note-se que o contraditório não é apenas mais uma qualidade do processo, mas sim requisito essencial ao seu próprio conceito - vale dizer, o controle procedimental da decisão ${ }^{393}$-; sendo que apenas o procedimento jurídico regulado de modo a garantir a participação daqueles que sofrerão seus efeitos ao seu final, em simétrica paridade, pode ser chamado de processo. ${ }^{394}$ Assim, pode-se dizer

\footnotetext{
${ }^{389}$ Rogério Lauria Tucci, Direitos e garantias..., ob. cit., p. 67.

${ }^{390}$ Pedro J. Bertolino, El debido proceso penal. La Plata: Platense, 1986, p. 21.

391 “Art. $5^{\circ}$ Todos são iguais perante a lei, sem distinção de qualquer natureza, garantindo-se aos brasileiros $e$ aos estrangeiros residentes no País a inviolabilidade do direito à vida, à liberdade, à igualdade, à segurança e à propriedade, nos termos seguintes:

(...)

LV - aos litigantes, em processo judicial ou administrativo, e aos acusados em geral são assegurados o contraditório e ampla defesa, com os meios e recursos a ela inerentes."

392 Aury Lopes Jr., Introdução crítica ao Processo Penal (Fundamentos da instrumentalidade constitucional). Rio de Janeiro: Lumen Juris, 2006, p. 229.

${ }^{393}$ Michele Taruffo, La prova dei fatti giuridici - nozioni generali. Milano: Giuffrè, 1992, p. 428.

${ }^{394}$ Antonio Magalhães Gomes Filho, Direito à prova..., ob. cit., p. 135.
} 
que ele é "imprescindível para a própria existência da estrutura dialética do processo”. 395

A garantia do contraditório configura-se na necessidade de informação e na possibilidade de reação, constituindo-se, nas conhecidas palavras de Joaquim Canuto Mendes de Almeida, a “(...) ciência bilateral dos atos e termos processuais e a possibilidade de contrariá-los". ${ }^{396}$ As partes devem ser comunicadas de todos os atos processuais praticados pela parte contrária, e ter a oportunidade de respondê-los, ao longo de todo o procedimento penal - tanto na fase processual quanto na investigatória. ${ }^{397}$

É importante que se ressalte que o contraditório, no processo penal, deve ser pleno e efetivo, não podendo se limitar à mera possibilidade de reação, como aconteceria no processo civil. Conforme ensina Antonio Scarance Fernandes, deve ser "pleno porque se exige a observância do contraditório durante todo o desenrolar da causa, até seu encerramento. Efetivo porque não é suficiente dar à parte a possibilidade formal de se pronunciar sobre os atos da parte contrária, sendo imprescindivel proporcionar-lhe os meios para que tenha condições reais de contrariálos. Liga-se, aqui, o contraditório ao princípio da paridade de armas, sendo mister, para um contraditório efetivo, estarem as partes munidas de forças similares". ${ }^{398}$ No mesmo sentido, sustenta Ada Pellegrini Grinover: "plenitude e efetividade do contraditório indicam a necessidade de se utilizarem todos os meios necessários para evitar que a disparidade de posições no processo possa incidir sobre seu êxito, condicionando-o a uma distribuição desigual de forças. A quem age e a quem se defende em Juízo devem ser asseguradas as mesmas possibilidades de obter a tutela de

\footnotetext{
395 Aury Lopes Jr., Introdução crítica..., ob. cit., p. 229.

${ }^{396}$ Joaquim Canuto Mendes de Almeida, Princípios fundamentais do processo penal. São Paulo: Revista dos Tribunais, 1973 , p. 82

${ }^{397}$ Existe entendimento em contrário - com o qual não concordamos - no sentido de que apenas é necessária a observância do contraditório, no processo penal, na fase processual, e não na fase investigatória (Inquérito Policial). Antonio Scarance Fernandes, integrante desta corrente doutrinária, sustenta que o artigo $5^{\circ}$, LV, da Constituição da República, ao mencionar o contraditório, apenas exige que ele seja observado em processos judicial ou administrativo, não estando aí abrangido o inquérito policial - o qual configuraria um conjunto de atos prativados por autoridade administrativa, não configuradores de um processo administrativo. (Antonio Scarance Fernandes, Processo Penal..., ob. cit., p. 67). No entanto, acreditamos que, ao assegurar o contraditório também aos "acusados em geral", o mesmo artigo de lei estendeu a referida garantia aos investigados em sede de Inquérito Policial.

${ }^{398}$ Antonio Scarance Fernandes, Processo penal constitucional, ob. cit, p. 61.
} 
suas razões. Mais ainda: no processo penal, com o seu máximo de publicismo e mínimo de disponibilidade, a reação não pode ser meramente eventual, mas há de fazer-se efetiva. O contraditório, agora, não pode ser simplesmente garantido, mas deve ser estimulado. E a contradição dialógica das partes há de ser real e não apenas formal. o juiz cuidará da efetiva participação das partes no contraditório, utilizando, para tanto, seus amplos poderes, a fim de que não haja desequilíbrios entre os ofícios da acusação e da defesa. Cabe ao juiz penal, portanto, integrar e disciplinar o contraditório, sem que com isso venha a perder sua imparcialidade, que sairá fortalecida, no momento da síntese, pela apreciação do resultado de atividades justapostas e paritárias, desenvolvidas pelas partes". 399

Rogério Lauria Tucci, por fim, salienta a necessidade da existência de um contraditório efetivo, real, para que seja preservada a liberdade jurídica do acusado, lembrando, ainda, que essa contraditoriedade real é indispositiva, indisponível, bem como é indispensável à plenitude de defesa, também para preservar a liberdade jurídica do investigado ou acusado. ${ }^{400}$ Todos esses dispositivos traduzem a preocupação do legislador com a "assecuração da liberdade jurídica do indivíduo pelo instrumento, técnico e público, do exercício da jurisdição criminal, que é o processo: somente por meio deste, como frisado e repisado, pode ser imposta sanção penal ao indigitado autor de crime ou contravenção", ${ }^{401}$

Nas palavras de Antonio Magalhães Gomes Filho: “tratase, portanto, de garantia fundamental de imparcialidade, legitimidade e correção da prestação jurisdicional: sem que o diálogo entre as partes anteceda ao pronunciamento estatal, a decisão corre o risco de ser unilateral, ilegítima e injusta; poderá ser um ato de autoridade, jamais de verdadeira justiça". ${ }^{402}$

\footnotetext{
399 Ada Pellegrini Grinover, O conteúdo da garantia do contraditório. In: Novas tendências do Direito Processual (de acordo com a Constituição de 1988). Rio de Janeiro: Forense Universitária, 1990, p. 18.

${ }^{400}$ Neste ponto, Tucci ressalta a indispensabilidade da defesa técnica, ou seja, a necessidade inafastável de que o acusado seja defendido, no decorrer do processo penal, por advogado, e que essa defesa seja efetiva. A defesa técnica deve ser exercida em conjunto com a auto-defesa, caracterizando assim defesa plena do acusado. (Rogério Lauria Tucci, Direitos e garantias.., ob. cit., pp. 42-46).

${ }^{401}$ Rogério Lauria Tucci, Direitos e garantias.., ob. cit., pp. 45-46.

402 Antonio Magalhães Gomes Filho, Direito à prova..., ob. cit., p. 137.
} 
Afirma, ainda, Aury Lopes Jr.: "o contraditório é, essencialmente, o direito de ser informado e de participar no processo. $E$ o conhecimento completo da acusação, o direito de saber o que está acontecendo no processo, de ser comunicado de todos os atos processuais. Como regra, não pode haver segredo (antítese) para a defesa, sob pena de violação ao contraditório". ${ }^{403}$

Tão importante é a garantia do contraditório no processo penal que é possível afirmar que ele é uma condição de validade das provas ${ }^{404}$, ou seja, apenas podem ser consideradas válidas aquelas provas produzidas na presença de contraditório efetivo.

Sabe-se, no entanto, que, no caso da infiltração de agentes - assim como ocorre com diversas outras medidas sigilosas ou cautelares no processo penal -, o contraditório imediato não é possível, sob pena de frustrar os fins da medida - por sua própria natureza sigilosa, não é possível contrapor a atuação do agente infiltrado no momento em que ela se desenrola.

Neste caso, para legitimar a prova obtida por meio desta técnica investigativa sem mitigar as garantias do devido processo legal, recorre-se a um redimensionamento dessas garantias, por meio do chamado contraditório diferido, postergado ou a posteriori - nomes atribuídos ao contraditório diferido no tempo ${ }^{405}$ - a fim de que - nas palavras de Antonio Magalhães Gomes Filho - "mesmo em condições excepcionais, seja possível assegurar a 'cognição adequada', que também integra a noção de 'devido processo', através da qual o juiz analisa os pressupostos da medida cautelar [no caso, da infiltração de agentes] com imparcialidade e tendo em conta as possíveis razões dos integrantes do contraditório, ainda que este só possa vir a ser exercido plenamente a posteriori", ${ }^{406}$

O mesmo autor traz uma lição interessante sobre a divisibilidade do contraditório, fracionando-o em dois atos (ou elementos ou

\footnotetext{
${ }^{403}$ Aury Lopes Jr., Introdução crítica..., ob. cit., p. 233.

${ }^{404}$ Ada Pellegrini Grinover, O conteúdo..., ob. cit., p. 21.

${ }^{405}$ Rogério Lauria Tucci, Direitos e garantias..., ob. cit, p. 224.

${ }^{406}$ Antonio Magalhães Gomes Filho, Presunção de inocência e prisão cautelar. São Paulo: Saraiva, 1991, p. 78.
} 
momentos), essenciais à sua formação e efetivação: a informação e a reação. ${ }^{407} \mathrm{O}$ primeiro momento, o da informação, corresponderia à ciência prévia para o exercício das atividades processuais próprias das partes; enquanto o segundo momento - da reação - seria o da possibilidade de participação ativa das mesmas, a fim de influenciar positivamente o espírito do juiz e obter, assim, a tutela preventiva. ${ }^{408}$ Para Magalhães, este segundo momento - a participação ativa das partes - pode se dar a diversos tempos, tanto preventivamente - quando o contraditório é instalado para debater a possibilidade de realização de determinado ato -, concomitantemente - quando ele se manifesta na própria prática do ato -, ou, ainda, posteriormente - quando consiste em manifestação subseqüente ao ato. ${ }^{409}$ Sustenta o autor, dessa forma, ser possível "partir" o contraditório em diversos atos, ou momentos de participação, sem quebrar a sua unidade teleológica, uma vez que tais atos estão todos voltados para um mesmo resultado final, que é a sentença. ${ }^{410}$

Vicente Greco Filho lembra, ainda, a esse respeito, que não há qualquer exigência na Constituição da República de que a efetivação do contraditório seja prévia ou simultânea ao ato realizado. Exige-se, apenas, que a manifestação contrária tenha eficácia prática. ${ }^{411}$

\subsubsection{A motivação da decisão que autoriza a infiltração.}

Também como expressão do devido processo legal, garantidor dos direitos e liberdades do indivíduo, encontra-se o dever de motivar do magistrado que autoriza a infiltração policial, previsto em nossa Constituição da

\footnotetext{
${ }^{407}$ Antonio Magalhães Gomes Filho, Presunção de inocência..., ob. cit., p. 137.

${ }^{408}$ Antonio Magalhães Gomes Filho, Presunção de inocência..., ob. cit., p. 138.

${ }^{409}$ Antonio Magalhães Gomes Filho, Presunção de inocência..., ob. cit., pp. 138-139.

${ }^{410}$ Antonio Magalhães Gomes Filho, Presunção de inocência..., ob. cit., p. 139.

${ }^{411}$ Vicente Greco Filho, Tutela constitucional das liberdades. São Paulo: Saraiva, 1989, p. 110-111.
} 
República no artigo 93, $\mathrm{IX}^{412}$. O dever de motivar, nas palavras de Piero Calamandrei, constitui o caráter mais importante e típico da racionalização da função jurisdicional. ${ }^{413}$

A motivação das decisões judiciais configura-se na demonstração, por parte do magistrado que pronuncia o ato decisório, de como apreendeu os fatos e interpretou a lei penal que sobre eles incide, propiciando, com as indispensáveis clareza, lógica e precisão, a perfeita compreensão da abordagem de todos os pontos questionados e, conseqüente e precipuamente, a conclusão atingida. ${ }^{414}$

Ela apresenta dupla função: ${ }^{415}$ primeiramente, serve como garantia política, propiciando a comunicação entre a atividade judiciária e a opinião pública, ensejando a apreciação crítica da sociedade acerca da forma como é aplicado concretamente o direito. ${ }^{416}$ De outra sorte, serve também como garantia processual, constituindo um dos requisitos formais das decisões ${ }^{417}$, funcionando como garantia de que todas as questões de fato e de direito suscitadas pelas partes foram apreciadas pelo magistrado em seu processo decisório ${ }^{418}$, de maneira imparcial ${ }^{419}$, e possibilitando às partes, ainda, o conhecimento dos argumentos da decisão para adequadamente impugná-la ${ }^{420}$.

Assim, por meio da motivação, o agente do Poder Judiciário deve demonstrar a forma com que interpretou a lei e se apreendeu os fatos da

412 “Art. 93. Lei complementar, de iniciativa do Supremo Tribunal Federal, disporá sobre o Estatuto da Magistratura, observados os seguintes princípios:

(...)

IX todos os julgamentos dos órgãos do Poder Judiciário serão públicos, e fundamentadas todas as decisões, sob pena de nulidade, podendo a lei limitar a presença, em determinados atos, às próprias partes e a seus advogados, ou somente a estes, em casos nos quais a preservação do direito à intimidade do interessado no sigilo não prejudique o interesse público à informação".

${ }^{413}$ Piero Calamandrei, Proceso y democracia. Buenos Aires: EJEA, 1960, p. 115.

${ }^{414}$ Rogério Lauria Tucci, Direitos e garantias..., ob. cit., p. 227.

415 Rogério Lauria Tucci acrescenta, ainda, uma terceira função à motivação da sentença, a qual seria a de "servir, quando correta e justamente proferido o ato decisório, para o aprimoramento da aplicação do direito, $e$, reflexivamente, para o aperfeiçoamento das instituições jurídicas $e$ da orientação jurisprudencial”. (Rogério Lauria Tucci, Direitos e garantias..., ob. cit., p. 228).

${ }^{416}$ Antonio Magalhães Gomes Filho, A motivação..., ob. cit., p. 81.

${ }^{417}$ Antonio Magalhães Gomes Filho, A motivação..., ob. cit., p. 95.

${ }^{418}$ Antonio Magalhães Gomes Filho, A motivação..., ob. cit., pp. 96-97.

419 Antonio Magalhães Gomes Filho, A motivação..., ob. cit., p. 98.

${ }^{420}$ Ada Pellegrini Grinover, O conteúdo..., ob. cit., p. 21. 
causa, "de sorte a que sua exposição, dotada de clareza, lógica e precisão, propicie perfeita compreensão de todos os pontos controvertidos, bem como da conclusão atingida, consubstanciada no julgamento da causa." 421 Só a motivação permite que se avalie se a racionalidade da decisão do magistrado predominou sobre o poder arbitrário - premissa fundante de um processo penal democrático. ${ }^{422}$

Nesse contexto, nos dizeres de Aury Lopes Jr., é possível afirmar que "a motivação serve para o controle da racionalidade da decisão judicial”. ${ }^{423}$ Importante ressaltar que "não se trata de gastar folhas e folhas para demonstrar erudição judiciária (e jurisprudencial) ou discutir obviedades. O mais importante é explicar o porquê da decisão, o que levou a tal conclusão". 424

Desse modo, o juiz que autoriza a infiltração policial deve, em seu despacho, expressar quais são as circunstâncias - levadas a seu conhecimento pelos órgãos policiais - que justificam a utilização desta medida excepcional, no lugar de outras medidas investigativas menos gravosas. ${ }^{425}$ Deve, ainda, explicitar o motivo da inaplicabilidade, no caso concreto, de tais medidas menos gravosas ${ }^{426}$, uma vez que a infiltração policial apenas deve ser levada a cabo em critério de absoluta excepcionalidade e subsidiariedade.

Em tempo, é importante destacar que não são apenas as sentenças definitivas em processos de caráter condenatório que merecem ser motivadas. No âmbito da jurisdição penal, todos os atos decisórios (à exceção dos meros despachos de expediente, desprovidos de carga decisória), para que sejam válidos, necessitam de motivação ${ }^{427}$, incluindo-se aqui as decisões interlocutórias ${ }^{428}$ - categoria

${ }^{421}$ Rogério Lauria Tucci e José Rogério Cruz e Tucci, Constituição de 1988 e processo. São Paulo: Saraiva, 1989, p. 74.

${ }^{422}$ Aury Lopes Jr., Introdução crítica..., ob. cit., p. 263. No mesmo sentido, Perfecto Andrés Ibáñez: “o simples fato de ampliar o campo do observável da decisão, não só para os destinatários diretos da mesma, mas, também, ao mesmo tempo e inevitavelmente, para terceiros, comporta para o autor da mesma a exigência de um princípio ou um adicional de justificação do ato; e uma maior exposição deste à opinião". (Perfecto Andrés Ibáñez, Sobre a motivação dos fatos na sentença penal. In: Valoração da prova e sentença penal. Rio de Janeiro: Lumen Juris, 2006, pp. 62-63.

${ }^{423}$ Aury Lopes Jr., Introdução crítica..., ob. cit., p. 264.

${ }^{424}$ Aury Lopes Jr., Introdução crítica..., ob. cit., p. 264.

${ }^{425}$ Claudia B. Moscato de Santamaría, El agente encubierto..., ob. cit., p. 59.

${ }^{426}$ Claudia B. Moscato de Santamaría, El agente encubierto..., ob. cit., p. 61.

${ }^{427}$ Rogério Lauria Tucci, Direitos e garantias..., ob. cit., p. 240. 
na qual se incluem as decisões autorizadoras da infiltração de agentes. Assim, da mesma forma do que ocorre com as sentenças terminativas, não podem as sentenças interlocutórias deixarem de ser motivadas, ou seja, devem conter fundamentação jurídica suficiente à evidenciação, tanto fática, como jurídica, do teor da resolução do órgão jurisdicional pronunciante. ${ }^{429}$

Deve-se ressaltar que não é suficiente a exposição, pelo juiz, de fórmulas genéricas, ou a mera enunciação da norma jurídica: é necessário que o magistrado proceda à valoração dos fatos conhecidos no processo, demonstrando, in casu, a ocorrência de fatos concretos que justifiquem a adoção da referida técnica investigativa, sob pena de esvaziar todo o significado de garantia do cidadão inerente à motivação. ${ }^{430}$ Nesse sentido, “o juiz tem a obrigação de dar conta de seus atos e não pode pura e simplesmente adaptar, num procedimento manipulatório, o fato à norma",431.

Com a motivação da decisão que determina a infiltração policial, busca-se o controle da lógica e da razoabilidade da aplicação desta medida, a qual mostra-se sobremaneira gravosa às liberdades individuais. ${ }^{432}$

\subsubsection{Princípio da publicidade processual.}

A regra, no sistema constitucional e processual brasileiro, é a publicidade plena, ou seja, em suas duas fases - a investigativa preliminar e a

\footnotetext{
${ }^{428}$ Decisões interlocutórias, segundo Rogério Lauria Tucci, são aquelas que são proferidas no curso do processo sem afetar o seu prosseguimento em direção à sentença extintiva (Rogério Lauria Tucci, Direitos $e$ garantias..., ob. cit., p. 242). São exemplos de decisões interlocutórias no processo penal: a decisão que recebe a denúncia, a decisão que determina a prisão preventiva do investigado, e, também, a decisão que autoriza a infiltração de agentes policiais.

${ }^{429}$ Rogério Lauria Tucci, Direitos e garantias..., ob. cit., p. 244.

${ }^{430}$ Alberto Silva Franco, Crimes hediondos..., ob. cit., p. 195.

${ }^{431}$ Alberto Silva Franco, Crimes hediondos..., ob. cit., p. 195.

${ }^{432}$ Claudia B. Moscato de Santamaría, El agente encubierto..., ob. cit., p. 59.
} 
processual -, a persecução penal deve ser, em regra, atividade pública ${ }^{433}$. Por meio da publicidade plena, é possível às partes e à sociedade o acompanhamento do desenrolar do processo penal. Assim, esta garantia toma contornos de garantia às partes - que passam a ter a segurança de um iter procedimental isento de vícios - e também à população como um todo - a qual tem a oportunidade de formar sua opinião sobre a retidão dos órgãos judiciais. ${ }^{434}$

Não por acaso, esta garantia encontra-se prevista constitucionalmente em paralelo com a necessidade de motivação das decisões, no artigo 93, IX, ${ }^{435}$ de nossa Constituição da República, sendo ambas as garantias orientadas para o controle externo das atividades do Poder Judiciário, ficando sob escrutínio tanto a imparcialidade do juiz quanto os erros do Poder Judiciário. ${ }^{436} \mathrm{Com}$ a publicidade dos atos processuais, são evitados excessos ou arbitrariedades no desenrolar da causa, surgindo, por isso, a garantia como reação aos processos secretos, proporcionando aos cidadãos a oportunidade de fiscalizar a distribuição da justiça. ${ }^{437} \mathrm{~A}$ publicidade processual tem, ainda, a função de legitimar a atuação estatal, uma vez que “somente quando os cidadãos sabem, por meio da publicidade, 'como', 'quando', 'porque' e 'por quem' os atos estatais são produzidos, alcançando legitimidade interna e externa, estes passam a ser aceitos e respeitados por todos. Não há quem, na condição de cidadão, aceite atos públicos sendo produzidos de maneira sigilosa”. 438

Assim, na lição de Rogério Lauria Tucci, "presenteandose a publicidade como requisito formal da realização da grande maioria de atos processuais, num procedimento demarcado em lei, a fim de que sejam prévia e amplamente conhecido, propiciando a participação dos interessados; atende, por outro

\footnotetext{
${ }^{433}$ Maurício Zanóide de Moraes, Publicidade e proporcionalidade na persecução penal brasileira. In: Sigilo no processo penal - eficiência e garantismo. São Paulo: Revista dos Tribunais, 2008, p. 41.

${ }^{434}$ Rogério Lauria Tucci, Direitos e garantias..., ob. cit., p. 211.

435 A publicidade dos atos processuais foi elevada ao status de garantia constitucional com a atual Carta Magna de 1988. Anteriormente, o tema era tratado pelo Código de Processo Penal, em seu artigo 792. (Rogério Lauria Tucci, Direitos e garantias..., ob. cit., p. 247). A inserção dessa garantia da Constituição das República teve o condão de alterar situações em que a regra era o julgamento em sigilo, como os julgamentos militares, os quais depois passaram a ser realizados com maior publicidade, assegurando-se a participação das partes. (Antonio Scarance Fernandes, Processo Penal..., ob. cit., p. 71).

${ }^{436}$ Rogério Lauria Tucci, Direitos e garantias..., ob. cit., p. 211.

${ }^{437}$ Antonio Scarance Fernandes, Processo Penal..., ob. cit., p. 72.

${ }^{438}$ Maurício Zanóide de Moraes, Publicidade..., ob. cit., p. 41.
} 
lado, ao reclamo de transparência da Justiça (particularmente da Criminal), serviente aos anseios dos integrantes do processo e aos desígnios do bem comum, em que avulta a imprescindibilidade de paz social, mais efetivamente de segurança pública”. 439

No entanto, para alcançar seus fins investigativos, é necessário que a determinação da infiltração se mantenha em sigilo. ${ }^{440}$ Do contrário, corre-se o risco de revelar-se a identidade do infiltrado, frustrando-se assim os fins da medida - e colocando-se em risco a integridade física do agente.

A nossa Constituição da República prevê a restrição da publicidade dos atos processuais em seu artigo $5^{\circ}$, inciso LX, "quando a defesa da intimidade ou o interesse social o exigirem". ${ }^{441}$ Vê-se, portanto, que, apesar de a publicidade dos atos processuais ser a regra, permite-se seu excepcionamento quando o exigirem o interesse público, o interesse social ou a defesa da intimidade. ${ }^{442}$ Nas palavras de Maurício Zanóide de Moraes: “Toda e qualquer persecução penal é atividade pública, com inevitáveis instantes de excepcionalidade constitucional de sigilo para alguns atos e em certas circunstâncias. Essa excepcionalidade é que deve, em cada caso concreto, passar pelo crivo da proporcionalidade, com o objetivo de atingir a legitimidade constitucional indispensável a todo ato estatal”. ${ }^{443}$

É necessário, porém, neste momento, fazer uma distinção ao quanto ao tipo da publicidade que será restringida. A publicidade externa de um procedimento é a que se garante aos terceiros estranhos à persecução penal ${ }^{444}$, e pode

${ }^{439}$ Rogério Lauria Tucci, Direitos e garantias..., ob. cit., p. 212.

${ }^{440}$ Claudia B. Moscato de Santamaría, El agente encubierto..., ob. cit., p. 63.

441 “Art. $5^{\circ}$ Todos são iguais perante a lei, sem distinção de qualquer natureza, garantindo-se aos brasileiros e aos estrangeiros residentes no País a inviolabilidade do direito à vida, à liberdade, à igualdade, à segurança e à propriedade, nos termos seguintes:

(...)

$L X$ - a lei só poderá restringir a publicidade dos atos processuais quando a defesa da intimidade ou o interesse social o exigirem".

${ }^{442}$ Rogério Lauria Tucci, Direitos e garantias..., ob. cit., p. 217. Tucci lembra ainda que as situações especiais nas quais se permite a publicidade restrita do processo penal encontram-se previstas, também, em pactos supranacionais, como a Convenção Européia para a Salvaguarda dos Direitos do Homem e das Liberdades Fundamentais (em seu artigo $6^{\circ}$ ), e o Pacto Internacional dos Direitos Civis e Políticos (artigo 14, 1); bem como em ordenamentos estrangeiros, como o italiano e o americano. (Rogério Lauria Tucci, Direitos e garantias..., ob. cit., p. 218).

${ }^{443}$ Maurício Zanóide de Moraes, Publicidade..., ob. cit., p. 42.

${ }^{444}$ Maurício Zanóide de Moraes, Publicidade..., ob. cit., p. 43. 
sempre ser restrita quando o objetivo é a proteção da intimidade das pessoas envolvidas na persecução penal - investigado, vítima, testemunhas, parentes e seus representantes, por exemplo - ou a proficuidade dessa atividade estatal; não resultado, dessa restrição, qualquer prejuízo para aqueles juridicamente interessados na causa. ${ }^{445}$

Por outro lado, a publicidade interna refere-se àquela garantida às partes, seus defensores e demais operadores do direito que atuam na persecução penal - policiais, servidores judiciais, peritos, entre outros -; e sua limitação, ainda que por um curto período de tempo, "tem o efeito imediato de criar uma desigualdade na persecução, pois somente ocorre para uma parte da persecução, qual seja o sujeito investigado/acusado, remanescendo irrestrita a publicidade interna para os demais sujeitos atuantes (Polícia Judiciária e Ministério Público)”. 446 Além desse efeito imediato, a limitação da publicidade interna implica ainda limitações ao exercício de outros direitos fundamentais do cidadão, tais como a defesa técnica e a autodefesa, o exercício do contraditório pleno e eficaz, a interposição de recurso contra eventual medida restritiva de direitos, e o exercício efetivo do habeas corpus, entre outros. $^{447}$

No caso da infiltração de agentes, para o sucesso da medida e a segurança física do agente e de seus familiares, é necessário que se imponha restrições à publicidade interna dos autos da infiltração, aos quais apenas poderão ter acesso os Magistrados atuantes no caso, seus órgãos auxiliares e os membros do Ministério Público, acarretando nas restrições de direitos supra citadas. No entanto, conforme assevera Maurício Zanóide de Moraes, "não se deve defender, com isso, que a publicidade interna nunca deva ser restringida, e é exatamente neste ponto que se insere a importância do princípio da proporcionalidade. É por esse crivo que devem passar os atos limitadores de direitos ou garantias do cidadão para que sejam constitucionalmente legítimos e dessa maneira se exerçam”. ${ }^{44}$ Assim, serve a proporcionalidade para avaliar o cabimento excepcional da restrição da publicidade interna.

\footnotetext{
${ }^{445}$ Maurício Zanóide de Moraes, Publicidade..., ob. cit., p. 43.

${ }^{446}$ Maurício Zanóide de Moraes, Publicidade..., ob. cit., p. 43.

${ }^{447}$ Maurício Zanóide de Moraes, Publicidade..., ob. cit., p. 43.

${ }^{448}$ Maurício Zanóide de Moraes, Publicidade..., ob. cit., p. 43.
} 
De se notar, por outro lado, que, após levada a cabo medida violadora da intimidade - tal como a infiltração de agentes - a publicidade externa dos autos deve permanecer restrita, mesmo após cessar a restrição à publicidade interna e a defesa tomar conhecimento da medida, pois, de outra sorte, o investigado teria sua intimidade exposta indiscriminadamente a terceiros. Acerca dessa questão, observa Maurício Zanóide de Moraes: "Não há como se tolerar, porém, que o cidadão, após violada a sua intimidade de modo justificável, possa ter o resultado dessa violação exposto a terceiros estranhos à persecução ou ao público em geral. Nesse caso, é perfeitamente proporcional e deve ser determinada pelo juiz a limitação da publicidade externa, com restrição de acesso aos autos, ou a parte deles, para aqueles terceiros". 449

\subsubsection{Presunção de inocência. Vedação da produção de prova contra si mesmo (nemo tenetur se detegere).}

A presunção de inocência ${ }^{450}$ do imputado - até prova em contrário decretada pela sentença definitiva de condenação ${ }^{451}$-, no ordenamento jurídico brasileiro, está expressamente consagrada no artigo $5^{\circ}$, LVII, de nossa Constituição da República ${ }^{452}$. Ela é, nos dizeres de Luigi Ferrajoli, um princípio fundamental de civilidade, o qual representa o fruto de uma opção garantista a favor da tutela da imunidade dos inocentes, ainda que ao custo da impunidade de algum

\footnotetext{
${ }^{449}$ Maurício Zanóide de Moraes, Publicidade..., ob. cit., p. 46.

${ }^{450}$ Também conhecida como "princípio da não-culpabilidade". (Alberto M. Binder, Introdução ao Direito Processual Penal. Rio de Janeiro: Lumen Juris, 2003, p. 85).

${ }^{451}$ Luigi Ferrajoli, Direito e razão. São Paulo: Revista dos Tribunais, 2006, p. 505.

452 “Art. $5^{\circ}$ Todos são iguais perante a lei, sem distinção de qualquer natureza, garantindo-se aos brasileiros $e$ aos estrangeiros residentes no País a inviolabilidade do direito à vida, à liberdade, à igualdade, à segurança e à propriedade, nos termos seguintes:

(...)

LVII - ninguém será considerado culpado até o trânsito em julgado de sentença penal condenatória”.

Note-se que a presunção de inocência também foi reconhecida pelas mais importantes declarações supranacionais relativas aos direitos humanos, a saber: a Declaração dos Direitos do Homem e do Cidadão (art. $9^{\circ}$ ); a Declaração Universal dos Direitos do Homem; e o Pacto de San José da Costa Rica (Convenção Americana sobre os Direitos Humanos (art. $8^{\circ}$ ). (Alberto M. Binder, Introdução..., ob. cit., pp. 85-86).
} 
culpado. ${ }^{453}$ Isso porque, ainda segundo o autor, os direitos dos cidadãos são ameaçados não só pelos delitos, mas também pelas penas arbitrárias, configurando-se assim então a presunção de inocência uma garantia tanto de liberdade e verdade quanto de segurança e defesa social. ${ }^{454}$

O fundamento da presunção de inocência reside no fato de que - nas palavras de Cesare Beccaria - um homem não pode ser considerado culpado antes da sentença proferida pelo Juiz; assim como a sociedade apenas pode lhe retirar a proteção pública após ter sido decidido que ele violou as condições pelas quais esta proteção lhe foi concedida. ${ }^{455}$ Conforme sustenta Alberto M. Binder, "ninguém pode ser considerado culpado se uma sentença, obtida em um julgamento (com as características que mencionamos e que formam a estrutura constitucional do julgamento), que o declare como tal. Por imposição constitucional, então, toda pessoa é inocente, e assim deve ser tratada, enquanto não for declarada sua culpa em uma sentença judicial". ${ }^{456}$

Processualmente, a presunção de inocência se manifesta mais diretamente no campo probatório, impondo à acusação a prova completa da culpabilidade do fato, e impondo-se, a contrario sensu, a absolvição do imputado se a culpabilidade não restar suficientemente demonstrada. ${ }^{457}$

Sendo a atividade probatória tarefa da acusação ${ }^{458}$, a partir do momento em que o imputado é presumidamente inocente, não lhe é incumbido provar nada. ${ }^{459}$ Pelo contrário: tem o acusado o direito de não produzir qualquer prova que possa incriminá-lo - é o chamado princípio nemo tenetur se detegere - também conhecido como nemo tenetur se ipsum accusare ${ }^{460}$-, de acordo com o qual reconhecese ao acusado "un vero e proprio diritto a non collaborare com l'autorirà

\footnotetext{
${ }^{453}$ Luigi Ferrajoli, Direito e razão. São Paulo: Revista dos Tribunais, 2006, p. 506.

${ }^{454}$ Luigi Ferrajoli, Direito..., ob. cit., p. 506.

${ }^{455}$ Cesare Beccaria, Dos delitos e das penas. São Paulo: Martin Claret, 2002, p. 35.

${ }^{456}$ Alberto M. Binder, Introdução..., ob. cit., p. 85.

${ }^{457}$ Aury Lopes Jr., Introdução crítica..., ob. cit., p. 188.

${ }^{458}$ Aury Lopes Jr., Introdução crítica..., ob. cit., p. 188.

${ }^{459}$ Aury Lopes Jr., Introdução crítica..., ob. cit., p. 189.

${ }^{460}$ Enrique Bacigalupo, El debido proceso penal. Buenos Aires: Hammurabi, 2005, p. 69.
} 
guidiziaria”461, e segundo o qual "o sujeito passivo não pode sofrer nenhum prejuízo jurídico por omitir-se de colaborar em uma atividade probatória da acusação ou por exercer seu direito de silêncio quando do interrogatório". ${ }^{462}$ Salienta Alberto M. Binder que, se o acusado não é culpado enquanto não for provada sua culpabilidade por meio de sentença, tampouco poderá ser tratado como culpado, o que implica que "não poderá ser restringido o seu direito de defesa e que não poderá ser obrigado a depor contra si mesmo". 463

O princípio nemo tenetur se detegere é, de acordo com Aury Lopes Jr., a "primeira máxima do garantismo processual acusatório" ${ }^{464}$, e traz, como corolários, i) a proibição da tortura; ii) o direito do acusado de permanecer em silêncio e de faltar com a verdade em suas respostas; iii) a proibição da obtenção da confissão mediante violência ou manipulação (tanto física quanto psíquica); iv) a negação do papel decisivo das confissões; e v) o direito do investigado de ser assistido por defensor no interrogatório. ${ }^{465}$

Assim, como decorrência do princípio nemo tenetur se detegere, não pode o sujeito passivo ser compelido a declarar a verdade, uma vez que, conforme anota Alberto M. Binder, "caso declare a verdade ou oculte informação, não estará fazendo outra coisa que exercer seu direito à própria defesa e de nenhuma maneira descumprindo um dever como o que têm as testemunhas em relação ao depoimento. Isto significa que é o acusado que tem o domínio e o poder de decisão sobre seu próprio depoimento. Conseqüentemente, somente ele determinará o que quer

\footnotetext{
${ }^{461}$ Vittorio Grevi, Nemo tenetur se detegere - interrogatorio dell'imputato e diritto al silenzio nel processo penale italiano. Milano: Giuffrè, 1972, p. 54.

${ }^{462}$ Aury Lopes Jr., Introdução crítica..., ob. cit., p. 242. Também merece destaque a definição formulada por Enrique Bacigalupo, segundo a qual o princípio do nemo tenetur se detegere (ou nemo tenetur se ipsum accusare, nas palavras do autor) corresponde a "um derecho del inculpado o imputado que se concreta como derecho a negar toda colaboración con la acusación, sin sufrir como consecuencia de ello ninguna consecuencia negativa, derivado del respeto a la dignidad de la persona, que constituye una parte esencial del proceso de um Estado de Derecho. (...) Más aún, el Estado es garante de que el sospechoso no se incrimine contra su voluntad, pues el Derecho vigente impone a las autoridades de persecución del delito el deber de instruir a cualquier persona que es interrogada como posible autor de un delito sobre los derechos que tiene reconocidos, especialmente sobre el derecho a guardar silencio y a no declararse culpabile". (Enrique Bacigalupo, El debido..., ob. cit., p. 69).

${ }^{463}$ Alberto M. Binder, Introdução..., ob. cit., p. 90.

${ }^{464}$ Aury Lopes Jr., Introdução crítica..., ob. cit., p. 243.

${ }^{465}$ Aury Lopes Jr., Introdução crítica..., ob. cit., p. 243.
} 
ou o que interessa declarar". ${ }^{466}$ Não pode, tampouco, ser obrigado a participar de qualquer atividade que possa incriminá-lo ou prejudicar sua defesa; ou ser interrogado sem a presença de seu defensor. E, por fim - mas não menos importante -, a obtenção da confissão do investigado - ou de qualquer informação que possa prejudicá-lo - não pode se dar por meio da manipulação ou do emprego de meios enganosos.

No entanto, sabe-se que um dos objetivos do agente infiltrado, enquanto oculto no seio da organização criminosa, é ganhar a confiança dos seus membros, a fim de que estes lhe revelem suas atuações, planos e delitos realizados, bem como confidenciem o modus operandi da organização e forneçam informações acerca dos seus demais integrantes. Essas revelações feitas pelos investigados ao agente - as quais, via de regra, mostram-se auto-incriminatórias -, no entanto, são claramente obtidas por meios enganosos, uma vez que o infiltrado mantém os investigados em erro em relação à sua identidade e qualificação.

Além disso, há que se considerar que a própria Constituição da República brasileira garante ao acusado o direito ao silêncio, previsto em seu artigo $5^{\circ}$, LXIII. ${ }^{467}$ Esta proteção constitucional se reflete, na lei ordinária, no artigo 186 do Código de Processo Penal ${ }^{468}$, que prevê o direito do réu de permanecer calado durante seu interrogatório. Pode-se afirmar, assim, que "o direito ao silêncio é apenas uma manifestação de uma garantia muito maior, insculpida no princípio nemo tenetur se deterge" ${ }^{469}$ Note-se que este direito é resguardado não apenas no ordenamento jurídico brasileiro, mas também nas mais importantes declarações supranacionais de direitos civis políticos e humanos: o Pacto Internacional sobre Direitos Civis e Políticos de

\footnotetext{
${ }^{466}$ Alberto M. Binder, Introdução..., ob. cit., p. 135.

467 “Art. $5^{\circ}$ Todos são iguais perante a lei, sem distinção de qualquer natureza, garantindo-se aos brasileiros $e$ aos estrangeiros residentes no País a inviolabilidade do direito à vida, à liberdade, à igualdade, à segurança e à propriedade, nos termos seguintes:

(...)

LXIII - o preso será informado de seus direitos, entre os quais o de permanecer calado, sendo-lhe assegurada a assistência da família e de advogado".

468 “Art. 186. Depois de devidamente qualificado e cientificado do inteiro teor da acusação, o acusado será informado pelo juiz, antes de iniciar o interrogatório, do seu direito de permanecer calado e de não responder perguntas que lhe forem formuladas.

Parágrafo único. O silêncio, que não importará em confissão, não poderá ser interpretado em prejuízo da defesa."

${ }^{469}$ Aury Lopes Jr., Introdução crítica..., ob. cit., p. 242.
} 
Nova Iorque - ratificado pelo Brasil em 06 de julho de 1992 (Decreto n. 592) - expressa, em seu artigo 14,3, g, que "toda a pessoa à qual é imputada a prática de infração penal tem o direito de não ser obrigada a depois contra si mesma, nem confessar-se culpada"; e a Convenção Americana sobre os Direitos Humanos (Pacto de San José da Costa Rica) ratificado pelo Brasil em 06 de novembro de 1992 (Decreto n. 678) - prevê, no mesmo sentido, em seu artivo $8^{\circ}, 2, g$, que o imputado tem o "direito de não ser obrigado a depor contra si mesmo, nem a declarar-se culpado". ${ }^{470}$

Assim sendo, vê-se que a opção do imputado de permanecer calado ao ser interrogado - tanto em sede de inquérito policial quanto em juízo - é um direito seu, reflexo do princípio nemo tenetur se detegere e expressão inafastável de sua auto-defesa, que não pode lhe ser subtraída em nenhuma hipótese. Conforme sustenta Rogério Lauria Tucci, "essa opção concedida ao preso, ou indiciado, logo no início da persecução penal, representa, outrossim, por um lado, a preambular conformação da autodefesa, com ou sem a integração da defesa técnica; e, por outro lado, o reconhecimento de que aquela resulta do exercício de um direito constitucionalmente estabelecido, encartado no de ampla defesa e particularizado no contraditório". 471

No entanto, ao "arrancar" do investigado informações confidenciais - e possivelmente auto-incriminatórias - mediante meios enganosos, fazendo parecer tratar-se de uma simples conversa entre colegas, o agente infiltrado não dá ao investigado ou ao réu a oportunidade - prevista constitucionalmente - de permanecer em silêncio, e de calar qualquer informação que possa vir a prejudicá-lo. Pelo contrário: o investigado não sabe que está conversando com um policial e que suas declarações podem ser usadas como prova contra ele em um eventual procedimento penal. Subtrai-se do imputado, assim, qualquer possibilidade de exercer sua autodefesa.

\footnotetext{
${ }^{470}$ Rogério Lauria Tucci, Direitos e garantias..., ob. cit., p. 366. É importante destacar, ainda, que integra também a garantia do nemo tenetur se detegere o direito do acusado de não contribuir, de nenhum modo, para a atividade probatória levada a cabo pelos órgãos de investigação, sem que isso configure crime de desobediência (Antonio Scarance Fernandes, Processo Penal..., ob. cit., p. 292). Nesse sentido, "o acusado não pode ser compelido a declarar nem a participar de qualquer atividade que possa porventura incriminálo ou prejudicar sua defesa”. (Marta Saad, O direito de defesa..., ob. cit., p. 301).

${ }^{471}$ Rogério Lauria Tucci, Direitos e garantias..., ob. cit., p. 394.
} 
Nesse sentido, ressaltam Manuel Monteiro Guedes Valente, Manuel João Alves e Fernando Gonçalves: “o recurso à figura do agente infiltrado consubstancia, intrinsecamente e em si mesma, uma técnica de investigação de moral duvidosa, uma vez que é o próprio suspeito que, actuando em erro sobre a qualidade do funcionário de investigação criminal, produz, involuntariamente, a prova de sua própria condenação". ${ }^{472}$

Tendo em consideração, assim, a limitação do princípio do nemo tenetur se detegere $e^{473}$, bem como da auto-defesa, do direito ao silêncio e da presunção de inocência do acusado nos casos em que atuam agentes infiltrados, passase a uma questão de difícil solução: é possível introduzir no processo penal as declarações auto-incriminadoras feitas ao agente infiltrado, sem que o declarante tivesse conhecimento de sua identidade e condição ${ }^{474}$

Note-se, em tempo, que não se pode aceitar que se excepcione a presunção de inocência para os casos de crimes ligados às organizações criminosas apenas devido à gravidade de tais crimes, justificando-se dessa maneira a introdução das declarações auto-incriminadoras feitas pelos investigados como provas no processo penal. Conforme ressalta Adauto Suannes, por aplicação do princípio constitucional da isonomia, não podem existir pessoas que sejam "mais presumidas" inocentes e outras "menos presumidas" inocentes - todos os indivíduos são presumidos igualmente inocentes, qualquer que seja o fato a eles atribuído. ${ }^{475}$ Assim sendo: "nada justifica que alguém, simplesmente pela hediondez do fato que se lhe imputa, deixe de merecer o tratamento que sua dignidade de pessoa humana exige. Nem mesmo sua condenação definitiva o excluirá do rol dos seres humanos, ainda que em termos práticos isso nem sempre se mostre assim. Qualquer distinção, portanto, que se pretenda fazer em razão da natureza do crime imputado a alguém inecente contraria o princípio da isonomia, pois a Constituição Federal não distingue entre mais-inocente $e$ menos-inocente. $O$ que deve contar não é o interesse da sociedade, que tem na

\footnotetext{
472 Manuel Monteiro Guedes Valente, Manuel João Alves e Fernando Gonçalves, O novo regime jurídico do agente infiltrado. Coimbra: Almedina, 2001, p. 27.

${ }^{473}$ Enrique Bacigalupo, El debido..., ob. cit., p. 71.

${ }^{474}$ Claudia B. Moscato de Santamaría, El agente encubierto..., ob. cit., p. 74.

475 Adauto Suannes, Os fundamentos éticos do devido processo penal. São Paulo: Revista dos Tribunais, 1999, p. 232.
} 
Constituição Federal, que prioriza o ser humano, o devido tratamento, mas o respeito à dignidade do ser humano, qualquer que seja o crime que lhe é imputado". 476

\subsection{6. $O$ direito à intimidade.}

A Constituição da República do Brasil resguarda, ainda, o direito dos cidadãos à intimidade e à vida privada, nos termos do seu artigo $5^{\circ}$, inciso $\mathrm{X}^{477}$. O direito à intimidade pode ser definido como “o direito de que dispõe o indivíduo de não ser arrastado para a ribalta contra a sua vontade. De subtrair-se à publicidade e de permanecer recolhido na sua intimidade ${ }^{478}$, e abrange a vedação da divulgação de palavras, escritos e atos realizados na esfera íntima da pessoa. ${ }^{479}$

No entanto, a atuação do agente infiltrado, por ser baseada no engodo, ofende o direito a intimidade do investigado, em todos os aspectos em que este se concretiza: seja na sua entrada no domicílio do imputado, seja na violação do sigilo existente nas conversas mantidas por este. ${ }^{480}$ Isso porque, conforme sustenta Mariângela Lopes Neistein, “a verdade é que o membro da organização somente autorizou a presença do agente infiltrado porque acreditava ser ele um de seus pares, um criminoso como ele. A autorização não existiria se o criminoso soubesse tratar-se de um policial". ${ }^{481}$

\footnotetext{
${ }^{476}$ Adauto Suannes, Os fundamentos éticos..., ob. cit., p. 232.

477 “Art. $5^{\circ}$ Todos são iguais perante a lei, sem distinção de qualquer natureza, garantindo-se aos brasileiros $e$ aos estrangeiros residentes no País a inviolabilidade do direito à vida, à liberdade, à igualdade, à segurança e à propriedade, nos termos seguintes:

(...)

$X$ - são invioláveis a intimidade, a vida privada, a honra e a imagem das pessoas, assegurado o direito a indenização pelo dano material ou moral decorrente de sua violação”.

${ }^{478}$ Paulo José da Costa Jr., O direito de estar só - A tutela penal do direito à intimidade. São Paulo: Siciliano, 2004, p. 54.

${ }^{479}$ Paulo José da Costa Jr., O direito..., ob. cit., p. 54.

${ }^{480}$ Mariângela Lopes Neistein, $O$ agente infiltrado..., ob. cit., p. 76.

${ }^{481}$ Mariângela Lopes Neistein, $O$ agente infiltrado..., ob. cit., p. 77.
} 
Assim sendo, é certo dizer que a autorização obtida pelo infiltrado para estar presente nas conversas - e, por vezes, até mesmo na residência dos investigados é viciada - porque obtida por meios enganosos ${ }^{482}-\mathrm{e}$, por isso, não pode ser considerada válida para permitir a restrição do direito fundamental à intimidade. ${ }^{483}$ Nesse sentido, a simples presença do infiltrado bastaria para constituir ofensa ao direito à intimidade do imputado, pois, "ocultando a sua condição de polícia, observa e ouve o que ocorre em conversas e condutas que têm lugar em sua presença, em domicílios de pessoas físicas ou em locais de pessoas jurídicas a que tem acesso". 484

Não é exagero afirmar, assim, que toda a atuação do agente infiltrado é fundada no engodo, resultando em lesão dos direitos fundamentais do investigado. Anota, nesse sentido, Marta Gómez de Liaño Fonseca-Herrero: "la obtención de información de relevancia punible viene motivada por el estabelecimiento de uma falsa relación de confianza, posibilitada por la ciscunstancia de ocultar la verdadera condición y utilizar uma ficticia identidad, no lo es menos, que la sola adopción de la medida del agente encubierto, debido al engaño facilitado por el aparato estatal, resulta lesiva de derechos fundamentales, a saber, el derecho a la autodeterminación informativa, el derecho a la intimidad em sentido amplio y, em su caso, el derecho a la intimidad en sentido estrito". 485

Tendo em conta o exposto, o Tribunal Europeu de Direitos Humanos já se posicionou no sentido de reconhecer que a atuação do agente infiltrado

\footnotetext{
${ }^{482}$ Manuel Augusto Alves Meireis esclarece que "o meio enganoso enquanto forma de obter uma prova, de a extorquir, pode assumir um conjunto multifacetado de situações que vão desde o emprego de tortura, à coacção e outras formas invencíveis de extorsão da confissão, como a ameaça com medida legalmente inadmissível (...), ou então a confissão que o argüido só fez porque as autoridades que procederam ao interrogatório o fizeram fraudulentamente acreditar na existência de material probatório irresistível, ou ainda a falsa informação ao argüido que um seu cúmplice já confessou; que há testemunhas presenciais do evento; que no objecto do crime foram identificadas as suas impressões digitais; que há gravações de conversas suas que o comprometem; a utilização de imitadores que simulam a voz do argüido, de um comparticipante ou de uma pessoa muito próxima. Meio enganoso haverá ainda em certas situações de produção ou exploração fraudulenta do erro. Desde as manifestações mais ardilosas e gravosas de indução dolosa activa do erro, ao aproveitamento do erro já subsistente, à mera omissão do esclarecimento destinado a dissipar o erro”. (Manuel Augusto Alves Meireis, O regime..., ob. cit., p. 205).

${ }^{483}$ Joaquín Delgado Martín, El proceso penal ante la criminalidad organizada. Revista actualidad penal, n. 1, 2000-2001, p. 09.

${ }^{484}$ Mariângela Lopes Neistein, $O$ agente infiltrado..., ob. cit., p. 77.

${ }^{485}$ Marta Gómez de Liaño Fonseca-Herrero, Criminalidad organizada..., ob. cit., p. 134.
} 
de fato ofende diretamente o direito à intimidade dos imputados. ${ }^{486}$ No entanto, dada a natureza excepcional de certos crimes, e a busca pela eficácia na persecução penal, tem autorizado o emprego deste meio de investigação de provas, desde que estejam presentes os requisitos inafastáveis da legalidade, legitimidade, necessidade e proporcionalidade. $^{487}$

\subsection{O agente infiltrado como testemunha.}

Findo o período de infiltração, existe a possibilidade de que o agente infiltrado seja ouvido durante a fase de instrução probatória. Entendemos que a oitiva do agente é fundamental para que a defesa exerça seu direito ao contraditório - ainda que de maneira diferida - e à ampla defesa, da melhor forma possível. É apenas dessa forma que ela terá a chance de questionar o agente acerca das circunstâncias em que se deu a infiltração e da forma como foram obtidas as provas juntadas aos autos.

Não há, no entanto, na legislação brasileira, qualquer disposição relativa à forma como se dará essa oitiva, ou ao status conferido ao agente no momento de sua oitiva.

Entendemos, a despeito do silêncio da lei, que o agente infiltrado deve ser ouvido como testemunha em Juízo. Testemunha, no processo penal, é toda pessoa que, não figurando no mesmo procedimento como vítima ou como acusado, encontra-se inteirado sobre os fatos investigados e vem a juízo prestar informações sobre eles. ${ }^{488}$ Ao teor do depoimento da testemunha dá-se o nome de "testemunho", cujo valor no processo penal reside na presunção de que alguém que

\footnotetext{
${ }^{486}$ Mariângela Lopes Neistein, O agente infiltrado..., ob. cit., p. 78.

${ }^{487}$ Mariângela Lopes Neistein, $O$ agente infiltrado..., ob. cit., p. 78.

${ }^{488}$ José Carlos G. Xavier de Aquino, A prova testemunhal no processo penal brasileiro. São Paulo: Juarez de Oliveira, 2002, p. 14. Claudia B. Moscato de Santamaría também oferece sua definição de testeminha: "individua que se encuentra directamente a la vista de un objecto, y conserva su imagen, por lo tanto es El llamado a declarar secún se experiencia acerca de ela existencia y natulaleza de los hechos investigados cuando su declaración pueda ser útil para descubrir la verdad”. (Claudia B. Moscato de Santamaría, El agente encubierto..., ob. cit., p. 64).
} 
tenha presenciado um acontecimento de relevância jurídica possa ter percebido, através de suas percepções sensoriais, a verdade dos fatos, e queira transmiti-la. ${ }^{489}$ Essa presunção alicerça-se em dois pontos: a capacidade de o homem perceber a ocorrência dos fatos e a de transmiti-los corretamente. ${ }^{490}$

Ora, o infiltrado encontra-se exatamente na posição descrita: é alguém que, não sendo vítima ou acusado, dispõe de informações sobre os fatos objeto da persecução penal e está apto a prestar informações sobre ele. Pode ser considerado, portanto, como uma testemunha. Marcelo Batlouni Mendroni compartilha desta mesma opinião: "Nada impede, mas ao contrário, tudo sugere, que ele sirva de testemunha - diga-se, importantíssima - a respeito das atividades da organização criminosa dentro da qual terá convivido. Estará em condições de descrever ao Juiz tudo o que tiver presenciado e relatar as atividades criminosas e os respectivos modus operandi". ${ }^{491}$ Note-se que o agente infiltrado, ao prestar declarações como testemunha, tem o dever de dizer sempre a verdade, sob pena de incorrer no crime previsto pelo artigo 342 do Código Penal. ${ }^{492}$

Nesse sentido, as chamadas "Regras de Mallorca", ou "Regras Mínimas de Processo Penal", elaboradas pelo Instituto Universitário de Criminologia da Universidade Complutense de Madrid, estabelecem, em seu artigo 29, 2:

“Art. 29. 2. Si la comprobación de un hecho se basa em la percepción de una persona, deverá ser ésta inrrogada en el juicio oral. Este interrogatorio no puede ser reemplazado por la lectura de un documento o de claración anteriormente escrita. La leyes nacionales establecerán las excepciones a este principio por razón de imposibilidad o grave dificultad de la reproducción de esta prueba. Em estos casos, se prodrán utilizar en el juicio oral las declaraciones practicadas con

\footnotetext{
${ }^{489}$ Karl Joseph Anton Mittermayer, Tratado da prova em matéria criminal. Rio de Janeiro: Jacinto, 1917, p. 284.

${ }^{490}$ José Carlos G. Xavier de Aquino, A prova testemunhal..., ob. cit., p. 15.

${ }^{491}$ Marcelo Batlouni Mendroni, Crime organizado..., ob. cit., p. 59.

492 “Art. 342. Fazer afirmação falsa, ou negar ou calar a verdade, como testemunha, perito, contador, tradutor ou intérprete em processo judicial, ou administrativo, inquérito policial, ou em juízo arbitral:

Pena - reclusão, de 1 (um) a e (três) anos, e multa”.
} 
anterioridad, siempre que hubiesen tenido lugar con intervención del defensor y se garantice a las otras partes la oportunidad de oponerse a la prueba aportada (principio de contradicción)", 493

De se ressaltar, porém, que o agente infiltrado, quando testemunha em Juízo, deve ter sua identidade mantida em sigilo, a fim de proteger a si próprio e à sua família de possíveis vinganças dos integrantes da organização criminosa na qual estava infiltrado ${ }^{494}$, conforme observa Marta Gómez de Liaño Fonseca-Herrero: "resulta evidente que cuando el policía abandona el entorno delictivo, la salvaguarda de su integridad física debe proseguir, incluso con mayor intensidad, pues los presuntos culpables intentarán impedir cualquier tipo de declaración incriminatoria concluyente". ${ }^{495}$ Além disso, se for identificado, o agente não mais poderá trabalhar como infiltrado em futuras operações, o que representa grande perda para os quadros da polícia, haja visto o alto grau de treinamento e especialização necessários ${ }^{496}$ a um agente infiltrado. ${ }^{497}$ Por isso, Marcelo Batlouni Mendroni defende o uso, no que couber, dos dispositivos da Lei n. 9.807/99 (Lei de Proteção a Testemunhas) para a proteção dos agentes infiltrados que vierem a ser ouvidos como testemunhas. ${ }^{498}$

${ }^{493}$ Claudia B. Moscato de Santamaría, El agente encubierto..., ob. cit., pp. 68-69 (destaque acrescentado).

${ }^{494}$ Marcelo Batlouni Mendroni, Crime organizado..., ob. cit., p. 59.

495 Marta Gómez de Liaño Fonseca-Herrero, Criminalidad organizada..., ob. cit., p. 233.

${ }^{496}$ Os agentes infiltrados passam por um rigoroso processo de seleção, formação, treinamento e supervisão, representando tal processo uma primeira garantia contra o eventual fracasso de suas operações. No Federal Bureau of Investigation (FBI) e nas polícias locais norte-americanas, por exemplo, existem dois níveis de seleção e treinamento. No primeiro, de caráter mais genérico, exige-se que o agente seja voluntário, que preste juramento, que tenha resistência física e psicológica frente a situações de tensão, espontaneidade, capacidade de improviso face a situações inesperadas, capacidade de manipulação e de representação, estabilidade familiar e motivação para o exercício daquela função. Já o segundo nível de seleção procura encontrar agentes com características específicas apropriadas para determinada operação em concreto, tais como a natureza do disfarce, o tempo da operação e o meio criminoso em que o agente terá de infiltrar-se. É ministrado aos agentes, então, um curso, o qual compreende uma parte teórica, que envolve o estudo de direito penal, direito processual penal e criminalística, e uma parte prática, mais intensa, que prepara o agente para se adaptar ao seu "disfarce" e aos riscos e exigências do trabalho, e engloba ainda preparação física e mental, curso de defesa pessoal, curso de tiro, lições sobre técnicas eletrônicas de vigilâncias, sobre problemas a enfrentar no trabalho infiltrado e sobre atuação. Os candidatos também são treinados para integrar-se em diversos meios sociais, ao nível de hábitos, linguagem e esquemas de transação de produtos de venda ilícita, entre outros aspectos da comunidade em que se infiltrarão. (Isabel Oneto, $O$ agente infiltrado..., ob. cit., pp. 84-85).

${ }^{497}$ Marcelo Batlouni Mendroni, Crime organizado..., ob. cit., p. 59.

${ }^{498}$ Marcelo Batlouni Mendroni, Crime organizado..., ob. cit., p. 59. O Projeto de Lei n. 3.731/1997 tem disposição justamente nesse sentido, de fornecer ao agente infiltrado a proteção prevista na Lei n. 9.807/99 (art. 13, II, do referido Projeto). 


\subsection{Possibilidade de utilização da prova obtida por meio da infiltração policial como base para condenação.}

Deve-se analisar, por fim, como serão valoradas as provas colhidas pelo agente infiltrado - tanto as juntadas diretamente aos autos quanto as declarações feitas por ele ao ser ouvido como testemunha.

Como já restou demonstrado, as provas obtidas por meio da infiltração policial são sempre fruto do engodo. O infiltrado angaria provas ao manter o investigado em um estado ilusório, fazendo-o acreditar que é alguém que, na realidade, não é. Assim sendo, podem ser tais provas valoradas por um juiz e, ainda, servir de alicerce a uma sentença condenatória?

Nos Estados Unidos da América, no caso Hoffa v. U.S. (1966), a Suprema Corte descartou qualquer lesão às Emendas Constitucionais do país ao afirmar que, ainda que o agente não tenha revelado sua identidade e função ao investigado, as conversas que este mantinha com ele eram totalmente voluntárias, assim como o fornecimento das informações. ${ }^{499}$

$\mathrm{Na}$ Alemanha, há uma forte discussão doutrinária e jurisprudencial acerca da validade das provas obtidas por meios enganosos. ${ }^{500} \mathrm{O}$ StrafprozeBbuch $(S t P O)$ - o conjunto de leis processuais penais do país -, em seu artigo 136, $a$, veda expressamente a utilização dos métodos enganosos em interrogatório. Porém, parte da doutrina e da jurisprudência defende a possibilidade da valoração das provas assim obtidas, em caráter excepcional, quando se tratar de crimes graves. ${ }^{501}$ Nesse sentido, decidiu o Tribunal Supremo Alemão - o BGH GSSt -, em 13 de maio de 1996: "si una persona privada, a instancias de la autoridad instructora, mantiene con el sospechoso del hecho una conversación dirigida a obtener datos sobre el objeto de la investigación, sin revelar el propósito de la misma, el contenido de la conversación puede ser valorado, en todo caso como prueba testifical, siempre que se trate del

\footnotetext{
${ }^{499}$ Claudia B. Moscato de Santamaría, El agente encubierto..., ob. cit., p. 75.

${ }^{500}$ Enrique Bacigalupo, El debido..., ob. cit., p. 70.

${ }^{501}$ Enrique Bacigalupo, El debido..., ob. cit., p. 70.
} 
esclarecimiento de un hecho punible de relevante significación y la investigación de los hechos con otros métodos hubiera tenido pocas perspectivas de êxito o hubiera sido esencialmente dificultada". 502

Claudia B. Moscato de Santamaría, por sua vez, entende que as declarações auto-incriminatórias feitas pelo investigado ao agente infiltrado, na ignorância da condição deste, podem servir para orientar novas medidas investigativas; não podendo jamais, no entanto, servir de base para uma sentença condenatória. Observa a autora: "A mi criterio, la información que recoja el agente encubierto podrá servir de base para la investigación em una etapa inicial del proceso, pero las declaraciones autoincriminatorias recibidas informalmente por dicho agente, $e$ incorporadas al proceso a través de su declaración testimonial no pueden dar base a uma condena". 503

Nesse sentido, aliás, já se manifestou a Corte Européia de Direitos Humanos, ao julgar o caso "Teixeira de Castro v. Portugal" condenação do investigado havia se baseado essencialmente nas declarações de dois policiais infiltrados. Em sua decisão, a referida Corte afirmou a validade das informações prestadas pelos agentes infiltrados como base para outras medidas investigativas em sede de instrução preparatória - e quando a natureza do delito o justifique. Condenou, porém, a sua utilização pelo juiz para justificar uma condenação. ${ }^{505}$

${ }^{502}$ Enrique Bacigalupo, El debido..., ob. cit., p. 70.

${ }^{503}$ Claudia B. Moscato de Santamaría, El agente encubierto..., ob. cit., p. 76.

${ }^{504}$ Neste caso, dois policiais à paisana entraram em contato com um indivíduo suspeito de tráfico de drogas (chamado de "V.S."), buscando, por meio dele, identificar seu fornecedor. Os policiais comentaram estar interessados na compra de heroína. V.S. indicou que poderia conseguí-la de Francisco Teixeira de castro mas que, para entrar em contato com ele, teria que ir até outra pessoa, chamada de "F.O.". V.S. e F.O. foram, então, na companhia dos policiais, até a residência de Teixeira de Castro, onde se deu a venda da droga. Imediatamente após, os policiais se identificaram e prenderam V.S., F.O. e Teixeira de Castro. Em sua defesa, Teixeira de Castro sustentou que sua prisão foi ilegal por infringir o artigo 6.1 da Convenção Européia de Direitos Humanos - que diz respeito ao direito do acusado a ser ouvido em uma audiência justa e pública, por um tribunal independente e imparcial -, além de ter sido resultado da conduta imoral e ilegal dos dois policiais, uma vez que o delito foi cometido única e exclusivamente devido à sua provocação, sem que houvesse nem mesmo um mandado judicial para tanto. (Belén Cassani, Agente encubiertos e informantes como medios de prueba contra el crimen organizado - Um análises desde la jurisprudencia de derechos humanos. In: El crimen organizado - Desafios y perspectivas en el marco de la globalización. Buenos Aires: Editorial Ábaco de Rodolfo Depalma, 2005, pp. 241-242).

${ }^{505}$ Claudia B. Moscato de Santamaría, El agente encubierto..., ob. cit., p. 77. 
Além disso, há que se considerar que o agente infiltrado deverá, necessariamente, prestar declarações de forma encoberta, mantendo sua identidade sob sigilo, para segurança sua e de sua família - o que certamente restringe a amplitude do direito de defesa do acusado. Por isso, cremos que esta condição, também, traz restrições às possibilidades de valoração destas declarações pelo Magistrado.

Nesse sentido, as "Regras de Mallorca", ou "Regras Mínimas de Processo Penal”, elaboradas pelo Instituto Universitário de Criminologia da Universidade Complutense de Madrid, também dispõem, em seu artigo 33, inciso 3:

“Art. 33. 3. En el ejercicio de la liberdad de apreciación de la prueba, los jueces en los supuestos des testigos de referencia, declaración de arrepentidos y situaciones análogas, tendrán em cuenta que solo com otras pruebas corroboradoras de tales testimonios podrá dictarse sentencia condenatória". 506

Assim, tem-se que apenas a prova obtida pelo agente infiltrado, de maneira isolada, não serve para embasar uma sentença condenatória. Para que possa subsidiar uma condenação, deve estar ela acompanhada de outros elementos de prova que a corroborem. ${ }^{507}$

\subsection{A compatibilização da figura do agente infiltrado com as garantias constitucionais.}

Ante todo o exposto, fica claro que a infiltração de agentes é meio investigação de prova extremamente agressivo aos direitos e garantias previstos e nossa Constituição da República. No entanto, devido às características peculiares das

\footnotetext{
${ }^{506}$ Claudia B. Moscato de Santamaría, El agente encubierto..., ob. cit., pp. 66-67 (destaque acrescentado).

507 O Projeto de Lei n. 3.731/1997 traz disposição expressa nesse sentido, em seu artigo 38, o qual assim dispõe: “Art. 38. O depoimento da testemunha e as declarações da vítima ou do acusado-colaborador protegidos pela preservação do sigilo apenas terão relevância probatória quando roborados por outros meios de prova".
} 
organizações criminosas, que dificultam ao máximo - se não impedem - a obtenção de provas para a persecução penal dos delitos a elas relacionados, é necessário que se pense na referida figura como "mal necessário" no combate ao crime organizado.

Importa, assim, verificar a possibilidade de compatibilizar a utilização da figura da infiltração de agentes com as liberdades individuais garantidas pela Constituição da República mencionadas ao longo deste trabalho, fazendo com que a restrição a estas, uma vez inevitável, seja reduzida ao seu mínimo. É que, para o emprego de meios excepcionais, se faz necessária a observância de cautelas excepcionais. $^{508}$

Ainda, imprescindível que se tenha sempre em mente o caráter excepcional da medida em questão, não se justificando, sob nenhuma hipótese, qualquer alargamento em seu âmbito de aplicação. ${ }^{509}$

\subsubsection{A eficiência e o garantismo na luta contra a criminalidade organizada.}

$\mathrm{O}$ antagonismo entre a repressão do crime organizado e a afirmação dos direitos fundamentais do cidadão é um exemplo claro do constante embate entre eficiência e garantismo ${ }^{510}$ existente no processo penal: quanto mais se criam medidas de combate à criminalidade, com vistas à eficiência da persecução penal, mais os direitos individuais restam agredidos, e vice-versa.

Isso ocorre porque as ditas medidas de combate ao crime organizado - via de regra, meios excepcionais de investigação de prova, tais como a infiltração de agentes - são, em si, gravosas aos direitos fundamentais, e - pior - são incorporadas ao nosso ordenamento jurídico sem que haja uma preocupação por parte

${ }^{508}$ Fátima Mata-Mouros, O agente infiltrado. Revista do Ministério Público. Lisboa, v. 22, n. 85, jan.mar./2001, p. 109.

${ }^{509}$ Alberto Silva Franco, Leis Penais Especiais..., ob. cit., p. 584.

510 Entende-se por garantismo no processo penal a "efetivação do devido processo legal, nos prismas subjetivo e objetivo: como garantias das partes, essencialmente do acusado, e como garantias do justo processo”. (Antonio Scarance Fernandes, Reflexões sobre as noções de eficiência e garantismo no processo penal. In: Sigilo no processo penal - eficiência e garantismo. São Paulo: Revista dos Tribunais, 2008, p. 10. 
do legislador em regulamentá-las de modo a torná-las compatíveis com os direitos fundamentais. Ou seja: não há uma preocupação por parte do legislador em harmonizar a eficiência do processo penal com o respeito às garantias constitucionais oferecidas ao indivíduo.

Faz-se necessária, portanto, uma mudança de paradigma. Ao invés de medir-se a eficiência, pura e simplesmente, pela "aptidão do meio utilizado para atingir o resultado ou gerar o efeito" ${ }^{, 511}$, ou, ainda, pelo número de condenações ${ }^{512}$, deve-se passar a entender por eficiente “o processo que, além de permitir uma eficiente persecução criminal, também possibilita uma eficiente atuação das normas de garantia"513; ou, ainda, "o procedimento que, em tempo razoável, permitir atingir um resultado justo, seja possibilitando aos órgãos da persecução penal agir para fazer atuar o direito punitivo, seja assegurando ao acusado as garantias do processo legal". 514 Nesse sentido, elabora Antonio Scarance Fernandes: "é dotado de eficiência o ordenamento formado por regras que permitam equilíbrio entre o interesse do Estado em punir autores de infrações penais e o interesse do acusado em se defender plenamente. Em outras palavras, o equilíbrio entre a exigência de assegurar ao investigado, ao acusado e ao condenado a aplicação das garantias fundamentais do devido processo legal e a necessidade de proporcionar aos órgãos de Estado encarregados da persecução penal mecanismos para uma atuação positiva. Não se deve pender para os extremos de um hipergarantismo ou de uma repressão a todo custo". 515

De fato, não se pode pensar em eficiência sem a observância das garantias constitucionais. ${ }^{516}$ Assim, será eficiente o meio de investigação de prova que permitir a repressão ao crime organizado mantendo o respeito ao núcleo essencial dessas garantias. ${ }^{517}$ Conforme ressalta Antonio Scarance Fernandes, "um meio de investigação é eficiente se ele se presta ao fim para o qual foi

\footnotetext{
${ }^{511}$ Antonio Scarance Fernandes, O equilíbrio na repressão..., ob. cit., p. 10.

${ }^{512}$ Antonio Scarance Fernandes, Reflexões..., ob. cit., p. 16.

${ }^{513}$ Antonio Scarance Fernandes, O equilíbrio na repressão..., ob. cit., p. 10.

514 Antonio Scarance Fernandes, Reflexões..., ob. cit., p. 16.

${ }^{515}$ Antonio Scarance Fernandes, O equilíbrio na repressão..., ob. cit., p. 10.

${ }^{516}$ Antonio Scarance Fernandes, O equilíbrio na repressão..., ob. cit., p. 11.

${ }^{517}$ Antonio Scarance Fernandes, O equilíbrio na repressão..., ob. cit., p. 11.
} 
previsto e não afronta norma de garantia. Será eficaz se, em uma investigação, produzir o resultado esperado e não ocorrer lesão indevida a garantias do investigado ou a direitos de terceiros". 518

Sabe-se que, como visto, no caso da infiltração policial, as ofensas às garantias constitucionais e aos corolários do devido processo legal são praticamente inevitáveis. Sabe-se, de toda sorte, que os direitos fundamentais não podem ser tidos como dogmas absolutos, a ponto de impedirem que qualquer ato persecutório restritivo de direito fundamental seja vedado. ${ }^{519}$ No entanto, faz-se mister cuidar para que tais restrições sejam as menores possíveis, a fim de alcançar-se a eficiência na persecução penal com a atuação eficaz das normas de garantia; buscandose sempre um equilíbrio entre a repressão penal e os direitos do indivíduo. Para isso, o melhor instrumento é o princípio da proporcionalidade.

\subsubsection{A aplicação do princípio da proporcionalidade.}

Ante a necessidade de equilíbrio entre a repressão penal e as liberdades do cidadão, o princípio da proporcionalidade é comumente invocado para justificar a adoção de medidas excepcionais de restrição a direitos individuais em relação ao crime organizado. Todavia, é importante notar que a sua aplicação deve observar os pressupostos e requisitos postos pela doutrina a fim de evitar excessos e não desguarnecer o indivíduo de salvaguardas fundamentais para a sua existência digna. $^{520}$

Este $_{\text {princípio }}{ }^{521}$, na forma como é conhecido atualmente, surgiu na Alemanha ${ }^{522}$, onde se desenvolveu principalmente após a Segunda Guerra

\footnotetext{
${ }^{518}$ Antonio Scarance Fernandes, O equilíbrio na repressão..., ob. cit., p. 11.

${ }^{519}$ Maurício Zanóide de Moraes, Publicidade..., ob. cit., p. 32.

${ }^{520}$ Antonio Scarance Fernandes, Equilíbrio..., ob. cit., p. 237.

${ }^{521}$ Convém destacar que parte da doutrina entende que a proporcionalidade não corresponde a um princípio, mas, sim, a um conjunto de regras, quais sejam, a regra da adequação, a regra da necessidade, e a regra da proporcionalidade em sentido estrito. (Bernardo Montalvão Varjão de Azevedo e Marcos de Aguiar Villas Bôas, Proporcionalidade e suas repercussões nas ciências criminais. Revista Brasileira de Ciências Criminais. São Paulo: Revista dos Tribunais, n. 74, ano 16, set.-out./2008, p. 248).
} 
Mundial $^{523}$, baseando-se na idéia de que a limitação da liberdade individual se justifica apenas para a concretização de interesses coletivos superiores. ${ }^{524}$ Buscava-se, com a proporcionalidade, coibir os excessos punitivos (administrativos e penais) do Estado, protegendo os direitos fundamentais do indivíduo. ${ }^{525}$ Posteriormente, a proporcionalidade difundiu-se em diversos países e em múltiplos ramos do Direito, com larga aplicação no Processo Penal. ${ }^{526}$

No Brasil, embora não haja norma constitucional expressa que lhe faça referência ou lhe trace o conteúdo ${ }^{527}$, a doutrina entende tratar-se de um princípio com status constitucional, que decorre do Estado de Direito - ou, vale dizer, da idéia mesma de direitos fundamentais ${ }^{528}$-, e que tem como ponto nevrálgico a ponderação de interesses em conflito. ${ }^{529}$ Nesse sentido, “o princípio da proporcionalidade, como uma das várias idéias jurídicas fundantes da Constituição, tem assento justamente aí, nesse contexto normativo no qual estão introduzidos os direitos fundamentais e os mecanismos de respectiva proteção. Sua aparição se dá a título de garantia especial, traduzida na exigência de que toda intervenção estatal nessa esfera se dê por necessidade, de forma adequada e na justa medida, objetivando a máxima eficácia e otimização dos vários direitos fundamentais concorrentes". 530

${ }^{522}$ No país, o princípio é conhecido como "princípio da proibição do excesso". (Nicolas Gozáles-Cuellar Serrano, Proporcionalidad y derechos fundamentales en el proceso penal. Madrid: Colex, 1990, p. 153).

${ }^{523}$ Maurício Zanóide de Moraes destaca o surgimento dos primeiros traços do princípio da proporcionalidade no âmbito legal na Grécia e Roma antigas. (Maurício Zanóide de Moraes, Publicidade..., ob. cit., p. 30).

${ }^{524}$ Antonio Scarance Fernandes, Processo penal..., ob. cit., p. 54.

${ }^{525}$ Maurício Zanóide de Moraes, Publicidade..., ob. cit., p. 31.

${ }^{526}$ Antonio Scarance Fernandes, Processo penal..., ob. cit., p. 54. Afirma o autor que, em verdade, "a idéia de proporcionalidade sempre esteve presente no Direito. Assim, em um sentido amplo, seria um princípio que obrigaria o operador jurídico a tratar de alcançar o justo equilíbrio entre os interesses em conflito. Aqui [no processo penal], será visto em um sentido mais restrito, como o princípio de garantia do indivíduo contra os abusos no exercício do poder".

${ }^{527}$ Maurício Zanóide de Moraes, Publicidade..., ob. cit., pp. 30-31.

${ }^{528}$ Suzana de Toledo Barros, O princípio da proporcionalidade e o controle de constitucionalidade das leis restritivas de direitos fundamentais. Brasília: Brasília Jurídica, 2003, p. 100.

${ }^{529}$ Aury Lopes Jr., introdução crítica..., ob. cit., p. 246.

${ }^{530}$ Suzana de Toledo Barros, $O$ princípio..., ob. cit., p. 95. Note-se que parte da doutrina brasileira - a exemplo da citada autora - entende que o princípio da proporcionalidade confunde-se com o princípio da razoabilidade (Suzana de Toledo Barros, O princípio..., ob. cit., p. 95). Outra vertente doutrinária, no entanto, defende se tratarem de dois princípios distintos, sustentando que "enquanto a proporcionalidade delineia uma relação de causalidade entre meio, fim e situação fática, a razoabilidade se vincula à apreciação de uma situação específica relativa a um sujeito específico, ou seja, compatibilizar o geral (o texto da lei, tomada esta como veículo destinado ao transporte de uma mensagem normativa) com o individual (o fato da 
O princípio da proporcionalidade deve ser entendido como uma relação de meio e fim; ${ }^{531}$ e tem por objetivo e razão de ser a busca de equilíbrio entre valores fundamentais contrastantes, baseando-se na idéia de que os direitos e garantias fundamentais não podem ser entendidos em sentido absoluto, em função da necessária restrição fruto da convivência social. Assim, por razões de necessidade, estando dois valores em confronto, um deles pode vir a ser restringido, enquanto o outro será protegido. ${ }^{532}$ Nesse sentido, sustenta Maurício Zanóide de Moraes: "Tratando-se do âmbito da persecução penal, no qual os conflitos surgem do entrechoque entre os direitos fundamentais (individuais) e o interesse persecutório (estatal), a proporcionalidade interfere para determinar quanto aqueles direitos podem ceder, sem que essa compressão signifique sua supressão". 533

De toda sorte, a aplicação desse princípio para solucionar conflitos de regras e valores exige a presença, in casu, de determinados pressupostos e requisitos - elaborados pela doutrina alemã com o objetivo de reduzir a carga de subjetividade na determinação do conteúdo da proporcionalidade ${ }^{534}$-, com o fim de preservar a unidade e a harmonia dos direitos fundamentais estabelecidos na Constituição da República. ${ }^{535}$ E, conforme lembra Maurício Zanóide de Moraes, "para chegar à conclusão de que o ato de compressão dos direitos fundamentais do cidadão é legítimo, porquanto proporcional, é necessário que ele passe por todos os filtros autorizadores daquele princípio (pressupostos e requisitos). Qualquer dissonância entre a conduta e esses filtros torna o ato constitucionalmente ilegítimo. Fora do

vida). Entende-se por situação específica uma situação de excepcionalidade. Nesse sentido, a razoabilidade é um dever de congruência (de eqüidade). Pode-se falar, então, que a razoabilidade estabelece uma relação de critério e medida, isto é, uma congruência entre o critério de diferenciação escolhido e a medida aplicada. $O$ critério não conduz à medida, pressupõe esta. Em suma, a razoabilidade é uma correlação entre duas importâncias”. (Bernardo Montalvão Varjão de Azevedo e Marcos de Aguiar Villas Bôas, Proporcionalidade..., ob. cit., p. 251).

${ }^{531}$ Bernardo Montalvão Varjão de Azevedo e Marcos de Aguiar Villas Bôas, Proporcionalidade..., ob. cit., p. 252. Os autores acrescentam, ainda, que, na realidade, a proporcionalidade é uma relação entre meio, situação fática e fim, uma vez que ela apenas poderá ser analisada no caso concreto, e jamais no campo das abstrações. Assim, "o meio é o instrumento hábil a alcançar o fim. O fim é uma situação da vida a qual é desejada e da qual se tem consciência”. Bernardo Montalvão Varjão de Azevedo e Marcos de Aguiar Villas Bôas, Proporcionalidade..., ob. cit., p. 253).

532 Antonio Scarance Fernandes, Processo penal..., ob. cit., p. 57.

${ }^{533}$ Maurício Zanóide de Moraes, Publicidade..., ob. cit., p. 32.

${ }^{534}$ Bernardo Montalvão Varjão de Azevedo e Marcos de Aguiar Villas Bôas, Proporcionalidade..., ob. cit., p. 256.

${ }^{535}$ Bernardo Montalvão Varjão de Azevedo e Marcos de Aguiar Villas Bôas, Proporcionalidade..., ob. cit., p. 252. 
âmbito da proporcionalidade, qualquer compressão a direito fundamental é ato ilegal de abuso de poder, seja sob a forma de excesso de poder seja como desvio de poder". 536

Primeiramente, há que se considerar o pressuposto formal da legalidade, em virtude do qual um direito individual não pode ser restrito sem a existência de prévia lei, elaborada por órgão constitucionalmente competente, imposta e interpretada de forma estrita ${ }^{537}$ (nulla coertio sine lege) ${ }^{538}$. Dessa forma, o uso de meios de investigação de prova extraordinários para a repressão da criminalidade organizada - como é o caso do agente infiltrado - só será possível, com invocação da proporcionalidade, se expressamente permitido pela legislação. ${ }^{539}$ No mesmo sentido, é necessário considerar que, ainda que falha a lei em vigor reguladora da matéria, ela deixa claro que este meio de investigação de provas apenas pode ser empregado na persecução de crimes ligados à criminalidade organizada. ${ }^{540}$ Ou seja: existe uma lei prévia indicando - ainda que rusticamente - quais são os casos em que as restrições de direitos advindas da medida em questão são admissíveis. Assim sendo, apenas é possível que a infiltração seja realizada nos os casos previstos em lei. Sempre que for realizada em qualquer outra hipótese não prevista legalmente, a medida será considerada abusiva. ${ }^{541}$

Além disso, deve-se observar o pressuposto material da justificação teleológica, do qual decorre que a limitação a um direito individual apenas tem razão de ser se tiver como objetivo efetivar valores relevantes do sistema constitucional. ${ }^{542}$ Conforme afirma Maurício Zanóide de Moraes, “sendo a

\footnotetext{
${ }^{536}$ Maurício Zanóide de Moraes, Publicidade..., ob. cit., p. 33.

${ }^{537}$ Antonio Scarance Fernandes, Processo penal..., ob. cit., p. 56.

${ }^{538}$ Maurício Zanóide de Moraes, Publicidade..., ob. cit., p. 33. O autor ressalta que a legalidade confere, a um só tempo, "( $i$ ) a segurança jurídica a todos os cidadãos para conhecerem em quais hipóteses e com que intensidade os agentes persecutórios podem agir e, também, (ii) a previsibilidade necessária para, de antemão, saber quando os agentes públicos agem dentro dos limites legais e se estão autorizados a restringir os direitos fundamentais”. (Maurício Zanóide de Moraes, Publicidade..., ob. cit., p. 34).

${ }^{539}$ Antonio Scarance Fernandes, Equilíbrio..., ob. cit., p. 238.

${ }^{540}$ Ainda que este trabalho se proponha a analisar a figura do agente infiltrado apenas no que se relaciona às organizações criminosas, é importante destacar que este meio de investigação de prova é admitido, também, na investigação dos delitos ligados ao tráfico de drogas, por força do disposto no artigo 53, inciso I, da Lei n. 11.343/2006 (Nova Lei de Drogas).

${ }^{541}$ Manuel Augusto Alves Meireis, $O$ regime..., ob. cit., p. 173.

${ }^{542}$ Antonio Scarance Fernandes, Processo penal..., ob. cit., p. 56.
} 
proporcionalidade um juízo de ponderação entre o meio a ser utilizado e o fim a ser atingido, a justificação teleológica visa introduzir nessa análise de meio-fim exatamente essa última parcela, qual seja, o fim. Nesse pressuposto, cabe analisar se o fim almejado é constitucionalmente legítimo e se possui relevância social. Esse 'fim' almejado, se socialmente relevante e constitucional, é que servirá de parâmetro para o estudo de todos os requisitos intrínsecos e extrínsecos da proporcionalidade". ${ }^{543}$ Dessa forma, se o fim pretendido estiver vedado pela Constituição da República, ou, ainda, não se mostrar socialmente relevante ${ }^{544}$, o pressuposto ora analisado não estará atendido. $^{545}$

Por fim, é necessário que - como visto - as medidas restritivas sejam impostas por juiz, mediante decisão motivada ${ }^{546}$. São os chamados requisitos extrínsecos ${ }^{547}$ da judicialidade (de acordo com a qual qualquer restrição a direito fundamental do cidadão deve ser previamente determinada por juiz natural ${ }^{548}$, conforme artigo $5^{\circ}$, incisos XXXVII e LIII da Constituição da República ${ }^{549}$ ) e da motivação (a qual deve ser a mais completa possível, abarcando todos os aspectos jurídicos envolvidos na questão e relacionando a eles os dados fáticos específicos do caso $^{550}$, sob pena de nulidade da decisão, nos termos do artigo 93, XI, da Constituição

\footnotetext{
${ }^{543}$ Maurício Zanóide de Moraes, Publicidade..., ob. cit., p. 34.

${ }^{544}$ Maurício Zanóide de Moraes destaca que é um erro imaginar que a persecução penal configura, sempre, uma atividade socialmente relevante, haja visto as hipóteses do crime de bagatela - de potencial lesivo insignificante -, ou dos crimes inseridos na área do consenso penal. Assim, há que se analisar o critério da relevância social caso a caso. (Maurício Zanóide de Moraes, Publicidade..., ob. cit., p. 35).

${ }^{545}$ Maurício Zanóide de Moraes, Publicidade..., ob. cit., p. 35.

${ }^{546}$ Antonio Scarance Fernandes, Processo penal..., ob. cit., p. 57. Para o autor, estes seriam os requisitos extrínsecos da judicialidade e da motivação. (Antonio Scarance Fernandes, Processo penal..., ob. cit., p. 57).

547 A judicialidade e a motivação são denominados "requisitos extrínsecos" pois não se relacionam com a análise do ato restritivo em sim, mas à forma como ele é determinado no caso concreto. (Maurício Zanóide de Moraes, Publicidade..., ob. cit., p. 36).

${ }^{548}$ Maurício Zanóide de Moraes, Publicidade..., ob. cit., p. 36.

549 “Art. $5^{\circ}$ Todos são iguais perante a lei, sem distinção de qualquer natureza, garantindo-se aos brasileiros $e$ aos estrangeiros residentes no País a inviolabilidade do direito à vida, à liberdade, à igualdade, à segurança e à propriedade, nos termos seguintes:

(...)

XXXVII - não haverá juízo ou tribunal de exceção;

(...)

LIII - ninguém será processado nem sentenciado senão pela autoridade competente”.

${ }^{550}$ Maurício Zanóide de Moraes, Publicidade..., ob. cit., p. 36.
} 
da República $\left.{ }^{551}\right) .{ }^{552}$ Nesse sentido, "afigura-se imprescindível a expedição de uma decisão judicial autorizadora da utilização do agente infiltrado, motivadamente, sobretudo no que se refere ao preenchimento de seus requisitos, em atenção às garantias do devido processo legal". 553

Atendidos estes pressupostos, deve-se atentar para o preenchimento dos requisitos intrínsecos que justificam e autorizam uma restrição aos direitos individuais: sua necessidade, sua adequação e a prevalência do valor protegido na ponderação dos interesses em confronto. ${ }^{554}$

Com o requisito da adequação - também conhecido como idoneidade ${ }^{555}$-, procura-se assegurar que a medida restritiva dos direitos fundamentais seja apta a alcançar o fim almejado $^{556}$, por meio da realização de um juízo de ponderação qualitativo e quantitativo do ato em relação ao sujeito que sofrerá a medida restritiva. ${ }^{557}$ São duas as exigências que devem ser atendidas para o preenchimento deste requisito: i) deve existir um fim constitucionalmente legítimo; e ii) a medida escolhida deve ser adequada para a obtenção deste fim. ${ }^{558}$ Assim, “não será admitido $o$ ataque a um direito do indivíduo se o meio utilizado não se mostrar idôneo à consecução do resultado pretendido". ${ }^{559}$ Antonio Scarance Fernandes ressalta que "a

551 “Art. 93. Lei complementar, de iniciativa do Supremo Tribunal Federal, disporá sobre o Estatuto da Magistratura, observados os seguintes princípios:

(...)

XI nos tribunais com número superior a vinte e cinco julgadores, poderá ser constituído órgão especial, com o mínimo de onze e o máximo de vinte e cinco membros, para o exercício das atribuições administrativas $e$ jurisdicionais delegadas da competência do tribunal pleno, provendo-se metade das vagas por antigüidade $e$ a outra metade por eleição pelo tribunal pleno".

${ }^{552}$ Nesse sentido, Maurício Zanóide de Moraes, Publicidade..., ob. cit., pp. 35-36, e Antonio Scarance Fernandes, Processo penal..., ob. cit., p. 57.

${ }^{553}$ Mariângela Lopes Neistein, O agente infiltrado..., ob. cit., p. 86.

${ }^{554}$ Antonio Scarance Fernandes, Processo penal..., ob. cit., p. 57.

${ }^{555}$ Maurício Zanóide de Moraes, Publicidade..., ob. cit., p. 37.

556 Sobre a adequação, considera Antonio Scarance Fernandes que "uma medida é adequada quando ostente qualidade essencial que a habilite a alcançar o fim pretendido (adequação qualitativa), quando a sua duração ou intensidade for condizente com a sua finalidade (adequação quantitativa) e quando dirigida a um indivíduo sobre o qual incidam as circunstâncias exigíveis para seu atuada (adequação subjetiva)". (Antonio Scarance Fernandes, Equilíbrio..., ob. cit., p. 238).

${ }^{557}$ Maurício Zanóide de Moraes, Publicidade..., ob. cit., p. 37.

${ }^{558}$ Denílson Feitoza Pacheco, O princípio da proporcionalidade no direito processual penal brasileiro. Rio de Janeiro: Lumen Juris, 2007, p. 153.

559 Antonio Scarance Fernandes, Processo penal..., ob. cit., p. 57. 
restrição ao indivíduo em face da necessidade de repressão à criminalidade organizada será adequada se for apta e relevante para demonstrar a prática do crime investigado ou imputado a alguém, se a duração não for excessiva e se atingir um indivíduo sobre o qual incidam as circunstâncias que conduzam à obtenção ou à produção da prova". 560

Nesse sentido, não se justifica a utilização da infiltração de agentes se a prova visada não pode ser obtida através desse meio de investigação: “ $A$ infiltração de agentes, por ser uma diligência restritiva a direitos fundamentais, somente poderá ser autorizada se for adequada e idônea para se alcançar o fim que se pretende. Deve-se fazer a seguinte pergunta: 'É a infiltração policial uma medida adequada para alcançar o fim pretendido?' A resposta necessariamente deverá ser afirmativa". 561

O segundo requisito a ser analisado é o da necessidade também conhecido como subsidiariedade, intervenção mínima ou, ainda, alternativa menos gravosa. ${ }^{562}$ Este requisito "obriga os órgãos do Estado a comparar as medidas restritivas aplicáveis que sejam suficientemente aptas para a satisfação do fim perseguido e a eleger, finalmente, aquela que seja menos lesiva para os direitos dos cidadãos". ${ }^{563}$ Para atender ao princípio da proporcionalidade, é necessário que o meio empregado ocasione a menor restrição possível aos direitos fundamentais. Se houver um meio menos gravoso para se alcançar o objetivo pretendido, esta deverá ser a escolhida. ${ }^{564}$ Dessa forma, "para impor uma restrição ao indivíduo, colocam-se, a quem exerce o poder, várias possibilidades de atuação, devendo ser escolhida a menos gravosa. Assim, entre as diversas opções, todas aptas a alcançar o fim, não é correto escolher

\footnotetext{
${ }^{560}$ Antonio Scarance Fernandes, Equlíbrio..., ob. cit., p. 238.

${ }^{561}$ Mariângela Lopes Neistein, $O$ agente infitlrado..., ob. cit., p. 87.

${ }^{562}$ Antonio Scarance Fernandes, Processo penal..., ob. cit., p. 57.

${ }^{563}$ Denílson Feitoza Pacheco, O princípio da proporcionalidade..., ob. cit., p. 199.

${ }^{564}$ Para Maurício Zanóide de Moraes, as características que devem orientar a escolha do meio menos gravoso são as seguintes: “(i) o respeito à intervenção e à restrição mínimas da esfera de direitos do sujeito que sofrerá a medida; (ii) a otimização dos direitos fundamentais diante das restrições a serem determinadas; e, por fim, (iii) a comparação empreendida, segundo o critério de eficácia, entre os meios idôneos”. (Maurício Zanóide de Moraes, Publicidade..., ob. cit., p. 38).
} 
aquela que imponha maiores restrições à obtenção do resultado, desprezando outras que também o atingiriam de forma menos danosa". 565

Nesse sentido, a infiltração de agentes apenas pode ser empregada no caso concreto quando a prova pretendida não puder ser obtida por através de nenhum outro meio menos gravoso, ou seja, quando não houver nenhuma outra medida apta a alcançar o mesmo fim ${ }^{566}$ : “O recurso a esta técnica de investigação só é de admitir no limite, ou seja, (...) quando a inteligência dos agentes de justiça ou os meios sejam insuficientes para afrontar com sucesso a actividade dos criminosos e a criminalidade ponha gravemente em causa os valores fundamentais que à justiça criminal cabe tutelar, e esgotados que estejam os restantes meios de investigação criminal". ${ }^{567}$ No mesmo sentido, sustenta Mariângela Lopes Neistein: "Não é em todo e qualquer caso de investigação da criminalidade organizada que o uso do agente infiltrado mostra-se necessário. Dependerá de minuciosa análise por magistrado. Deve o Juiz verificar, em cada caso concreto, se outros meios de investigação menos ofensivos não seriam suficientes para a descoberta dos crimes". 568

Contudo, o fato de uma prova ser necessária não significa que ela será por isso, sem mais, admitida. É necessário que se leve em conta o bem que se irá sacrificar e o interesse que, em concreto, se pretende alcançar. ${ }^{569}$ Assim, o terceiro requisito a ser observado é o da proporcionalidade em sentido estrito, para que se constate, entre os valores em conflito - o que impele à medida restritiva e o que protege o direito individual a ser violado - qual deve prevalecer. ${ }^{570}$ Nas palavras de Maurício Zanóide de Moraes, "é uma opção subjetiva do julgador, que, diante dos dados fáticos específicos, deverá decidir se é aceitável sacrificar um direito fundamental e, ainda, se isso ocorrer, em qual limite (extensão e duração) tal sacrifício se dará". ${ }^{571}$ Trata-se de um esforço para alcançar-se a justa medida, a qual corresponde, em verdade, ao sopesamento entre as

\footnotetext{
565 Antonio Scarance Fernandes, Processo penal..., ob. cit., p. 58.

${ }^{566}$ Antonio Scarance Fernandes, Equlíbrio..., ob. cit., p. 239.

${ }^{567}$ Manuel Monteiro Guedes Valente, Manuel João Alves e Fernando Gonçalves, O novo regime jurídico..., ob. cit., p. 39.

${ }^{568}$ Mariângela Lopes Neistein, $O$ agente infitlrado..., ob. cit., p. 89.

${ }^{569}$ Manuel Augusto Alves Meireis, $O$ regime..., ob. cit., p. 187.

${ }^{570}$ Antonio Scarance Fernandes, Processo penal..., ob. cit., p. 58.

${ }^{571}$ Maurício Zanóide de Moraes, Publicidade..., ob. cit., pp. 39-40.
} 
desvantagens dos meios e as vantagens dos fins ${ }^{572}$ : deve-se comprovar que a medida restritiva, ainda que adequada e necessária, não acarreta uma lesão excessiva do direito afetado. ${ }^{573}$ Assim, a restrição ao direito fundamental apenas é justificável se o valor por ela resguardado prepondera sobre o valor protegido pelo direito a ser restringido: "Haverá observância ao princípio da proporcionalidade se predominar o valor de maior relevância, evitando-se, assim, que se imponham restrições aos direitos fundamentais desmedidas, se comparadas com o objetivo a ser alcançado. Assim, o meio, adequado e necessário para determinado fim, é justificado se o valor por ele resguardado prepondera sobre o valor protegido pelo direito a ser restringido". ${ }^{574}$

De se notar, destarte, que não se trata de uma ponderação abstrata e genérica entre o direito a obter ou produzir prova criminal e o direito fundamental do indivíduo, mas sim de uma verificação do justo equilíbrio em cada caso concreto. ${ }^{575}$ Dessa forma, no caso específico da infiltração policial, os valores sacrificados pela atuação dos agentes não podem ser mais relevantes do que aqueles que os que se busca proteger com a medida, concluindo-se que, "além de se verificar a adequação e a necessidade da medida, observadas em cada caso concreto, é preciso observar se a inclinação da balança a favor dos interesses da sociedade se justifica, em face da gravidade do crime, da duração da infiltração, das faculdades concedidas ao agente e do destino a ser dado às informações obtidas. Somente após detida análise, que somente será possível com a estrita observância das regras legais que expressamente tratarem do tema, poder-se-á dizer se a medida é proporcional e, em sendo, ser judicialmente autorizada a utilização do agente infiltrado". 576

${ }^{572}$ Bernardo Montalvão Varjão de Azevedo e Marcos de Aguiar Villas Bôas, Proporcionalidade..., ob. cit., p. 260.

${ }^{573}$ Nicolas Gonzáles-Cuellar Serrano, Proporcionalidad..., ob. cit., p. 225.

${ }^{574}$ Antonio Scarance Fernandes, Processo penal..., ob. cit., p. 58.

${ }^{575}$ Antonio Scarance Fernandes, Equlíbrio..., ob. cit., p. 239.

${ }^{576}$ Mariângela Lopes Neistein, $O$ agente infitlrado..., ob. cit., pp. 91-92. 


\section{CAPÍTULO 4 - DIREITO COMPARADO}

A infiltração de agentes é meio de investigação de prova encontrada em quase todos os países do mundo, à exceção de Luxemburgo ${ }^{577}$, ainda que em alguns ordenamentos esta figura não esteja positivada. ${ }^{578} \mathrm{~A}$ seguir, analisaremos, ainda que superficialmente, as regulamentações legais existentes acerca do tema nos ordenamentos jurídicos de alguns países, a saber: Alemanha, Argentina, Espanha, Estados Unidos da América, França e Portugal.

\subsection{Alemanha.}

Na Alemanha, à semelhança do que ocorre no Brasil, não há definição jurídica satisfatória de crime organizado. ${ }^{579}$ Todavia, nos últimos vinte e cinco anos, os legisladores germânicos vêm buscando meios de investigação que possam fazer frente ao aumento vertiginoso deste tipo de criminalidade. Nesse contexto, o agente infiltrado foi introduzido no ordenamento jurídico alemão pela Gesetz zur Bekämpfung des illegalen Rauschgifthandels und anderer Erscheinungsformen der Organisierten Kriminalität (OrgK - Lei contra o tráfico ilícito de drogas e outras manifestações da criminalidade organizada), de 22 de setembro de 1992, a qual introduziu os artigos 110 , alíneas $a$ a $e,{ }^{580}$ na lei processual penal do país StrafprozeBbuch (StPO).

\footnotetext{
${ }^{577}$ Isabel Oneto, $O$ agente infiltrado..., ob. cit., p. 96.

${ }^{578}$ Isabel Oneto, $O$ agente infiltrado..., ob. cit., p. 19.

${ }^{579}$ Jorg Kinzig, Mesures de lutte contre la criminalité organizée em Allemagne. In: Criminalité organisée des représentations sociales aux définitions juridiques. Paris: L.G.D.J; Bruxelles: Bruylant; Genève: Georg, 2004, p. 647.

580 "Section 110a. [Undercover investigators]

(1) Undercover investigators may be used to clear up criminal offenses where there are sufficient factual indications showing that a criminal offense of considerable importance has been committed:

1. in the sphere of illegal trade in drugs or weapons, of counterfeiting money or official stamps,

2. in the sphere of national security (sections 74 a, 120 Courts Constitution Act),
} 
3. on a commercial or habitual basis or

4. by a member of a gang or in some other organized way.

Undercover investigators may also be used to clear up serious criminal offenses where there is a risk of repetition in view of certain facts. Their use shall only be admissible if clearing up the serious criminal offense using some other means would offer no prospects of success or be much more difficult. Undercover investigators may also be used to clear up serious criminal offenses where the special significance of the offense makes the operation necessary and other measures would offer no prospects of success.

(2) Undercover investigators shall be officials in the police force who carry out investigations with a changed and lasting identity (legend) being conferred on them. They shall be entitled to take part in legal transactions using their legend.

(3) Where it is indispensable for building up or maintaining a legend, relevant documents may be drawn up, altered and used.

Section 110b. [Consent of the Public Prosecution Office; Consent of the Judge; Non-Disclosure of Identity]

(1) Use of undercover investigators shall be admissible only after the consent of the public prosecution office has been obtained. In exigent circumstances and if the public prosecution office's decision cannot be obtained in time, such decision shall be obtained without delay; the measure shall be ended if the public prosecution office does not give its consent within three days. Consent shall be given in writing and for a specified period. Extensions shall be admissible providing the conditions for use of undercover investigators are still fulfilled.

(2) Use of undercover investigators:

1. concerning a specific accused, or

2. which involve the undercover investigator entering private premises which are not generally accessible

shall require the consent of a judge. In exigent circumstances consent of the public prosecution office shall suffice. Where the public prosecution office's decision cannot be obtained in time, it shall be obtained without delay. The measure shall be ended if the judge does not give his consent within three days. Subsection (1), third and fourth sentences, shall apply mutatis mutandis.

(3) The identity of the undercover investigator may be kept secret even after the operation has ended. The public prosecutor and the judge responsible for the decision whether to give consent may require the identity to be revealed to them. In all other cases, maintaining the secrecy of the identity in criminal proceedings shall be admissible under the terms of Section 96, particularly if there is cause for concern that revealing the identity will endanger the life, limb or liberty of the undercover investigator or of another person or endanger the continued use of the undercover investigator.

Section 110c. [Entering Private Premises]

Undercover investigators may use their legend and enter private premises with the consent of the entitled person. Such consent may not be obtained by any pretense of a right of access extending beyond the use of the legend. The undercover investigator's powers shall otherwise be determined by this statute and by other legal provisions.

Section 110d. [Notification]

(1) Persons whose private premises, not being generally accessible, have been entered by the undercover investigator, shall be notified of the operation as soon as this can be done without endangering the purpose of the investigation, public security, life or limb of another or the possible continued use of the undercover investigator.

(2) Decisions and other documents relating to use of the undercover investigators shall be kept by the public prosecution office. They shall only be included in the files if the preconditions set out in subsection (1) have been fulfilled.

Section 110e. [Use of Information Obtained]

Personal data obtained by use of undercover investigators may be used as evidence in other criminal proceedings only insofar as during their evaluation information was obtained which is required to clear up one of the criminal offenses listed in Section 110a subsection (1); Section 110d subsection (2) shall remain unaffected". 
No país, o recurso a agentes infiltrados está sujeito ao princípio da subsidiariedade, permitindo-se a utilização deste meio de investigação apenas quando as provas pretendidas não possam ser obtidas por outros meios. Ainda, é necessário que o crime seja considerado grave e que esteja relacionado com os crimes de tráfico de drogas ou de armas; falsificação de moeda, documentos ou valores; segurança do Estado; ou que tenha sido cometido por um grupo organizado ${ }^{581}$, nos termos do artigo 110, $a$, do StPO.

A lei alemã (artigo 110, alínea $e$, do $S t P O$ ) ainda é enfática ao afirmar que a infiltração de agentes só poderá ocorrer uma vez presentes indícios suficientes da materialidade do delito, ou o perigo de sua repetição. ${ }^{582}$

Note-se que, naquele país, a infiltração de agentes apenas poderá ser efetuada mediante autorização prévia da autoridade judiciária, conforme determina o artigo 110, alínea $c$, da lei processual penal. Em casos de urgência, o magistrado pode ser substituído por um membro do Ministério Público. Caso nem a autorização judicial nem a ministerial sejam possíveis, o agente poderá agir, em casos de urgência, sem a autorização, mas esta deverá ser obtida dentro de três dias, sob pena de anulação da operação. ${ }^{583}$

Importante destacar que a lei alemã diferencia os agentes infiltrados dos informantes (informanten) e das chamadas "pessoas de confiança" (vertrauenspersonen) - ambos considerados como meras testemunhas pelo texto legal. Os infiltrados são diferenciados, também, dos agentes provocadores, baseando-se para isso na forma, intensidade e objetivo da influência exercida pelo infiltrado sobre o investigado, bem como na sua própria predisposição para o cometimento de crimes. ${ }^{584}$

O cometimento de crimes pelo agente no decurso de uma infiltração não é permitido pela lei alemã. A saída legal encontrada pelos infiltrados forçados a praticar delitos durante uma operação é, então, a invocação de uma causa de

\footnotetext{
${ }^{581}$ Isabel Oneto, $O$ agente infiltrado..., ob. cit., p. 97.

${ }^{582}$ Isabel Oneto, $O$ agente infiltrado..., ob. cit., p. 97.

${ }^{583}$ Isabel Oneto, $O$ agente infiltrado..., ob. cit., p. 97.

${ }^{584}$ Isabel Oneto, $O$ agente infiltrado..., ob. cit., p. 97.
} 
justificação ou de exclusão de culpa, o que costuma gerar certa controvérsia jurisprudencial. ${ }^{585}$

\subsection{Argentina.}

A Lei n. 24.424, de janeiro de 1995, que alterou a Lei n. 23.737 (Ley de Estupefacientes argentina), regulamenta o agente infiltrado no ordenamento jurídico argentino. Nos termos de seu artigo $6^{\circ}$ (que insere o artigo 31 bis à Lei n. 23.737) $)^{586}$, a infiltração de agentes apenas pode ocorrer durante o curso de uma investigação e com o fim de comprovar o cometimento de algum dos delitos previstos no texto desta própria lei ou, ainda, no artigo 866 do Código Aduanero ${ }^{587}$. A operação pode, também, ter como objetivo impedir a consumação de algum dos delitos

\footnotetext{
${ }^{585}$ Isabel Oneto, $O$ agente infiltrado..., ob. cit., p. 98.

586 “Art. $6^{\circ}$-- Incorpórase como art. 31 bis a la ley 23.737, el siguiente:
}

Art. 31 bis. -- Durante el curso de una investigación y a los efectos de comprobar la comisión de algún delito previsto en esta ley o en el art. 866 del Código Aduanero, de impedir su consumación, de lograr la individualización o detención de los autores, partícipes o encubridores, o para obtener y asegurar los medios de prueba necesarios, el juez por resolución fundada podrá disponer, si las finalidades de la investigación no pudieran ser logradas de otro modo, que agentes de las fuerzas de seguridad en actividad, actuando en forma encubierta:

a) Se introduzcan como integrantes de organizaciones delictivas que tengan entre sus fines la comisión de los delitos previstos en esta ley o en el art. 866 del Código Aduanero, y

b) Participen en la realización de alguno de los hechos previstos en esta ley o en el art. 866 del Código Aduanero.

La designación deberá consignar el nombre verdadero del agente y la falsa identidad con la que actuará en el caso, y será reservada fuera de las actuaciones y con la debida seguridad.

La información que el agente encubierto vaya logrando, será puesta de inmediato en conocimiento del juez.

La designación de un agente encubierto deberá mantenerse en estricto secreto. Cuando fuere absolutamente imprescindible aportar como prueba la información personal del agente encubierto, éste declarará como testigo, sin perjuicio de adoptarse, en su caso, las medidas previstas en el art. 31 quinques”.

587 “Artículo 866.- Se impondrá prisión de 3 a 12 años en cualquiera de los supuestos previstos en los arts. 863 y 864 cuando se tratare de estupefacientes en cualquier etapa de su elaboración. Estas penas serán aumentadas en un tercio del máximo y en la mitad del mínimo cuando concurriere alguna de las circunstancias previstas en los incs. a), b) c) d) y e) del art. 865 o cuando se tratare de estupefacientes elaborados o semielaborados que por su cantidad estuviesen inequívocamente destinados a ser comercializados dentro o fuera del territorio nacional". 
relacionados; identificar ou prender seus autores, partícipes ou quem ajude a acobertálo; ou ainda obter os meios de prova necessários à sua persecução penal. ${ }^{588}$

Note-se que a lei argentina apenas permite o recurso ao agente infiltrado quando se trata de uma investigação já em curso - ou seja, não é possível utilizar-se da infiltração de agentes para iniciar um procedimento penal. ${ }^{589} \mathrm{~A}$ infiltração deve ser autorizada previamente pelo Magistrado competente e, uma vez infiltrado, o agente deve reportar imediatamente as informações obtidas ao juiz que autorizou a operação, nos termos do artigo $6^{\circ}$ da Lei n. 24.424 (artigo 31 bis da Lei $n$. $23.737) .^{590}$

Além disso, à semelhança do que determina a legislação brasileira, o ordenamento argentino não permite que sejam infiltrados indivíduos estranhos aos quadros da polícia. Conforme determina a Lei n. 24.424, o agente infiltrado deve ser um policial ou um funcionário das forças armadas ("fuerzas de seguridad ${ }^{\text {591 }}$ ) argentinas ${ }^{592} .593$

Quanto ao cometimento de delitos por parte do agente na condição de infiltrado, o ordenamento argentino optou por criar uma hipótese de escusa absolutória - no caso portenho, bastante ampla - para isentá-lo de responsabilidade

${ }^{588}$ Texto legal.

${ }^{589}$ Carlos Enrique Edwards, El arrepentido..., ob. cit., p. 59.

${ }^{590}$ Carlos Enrique Edwards, El arrepentido..., ob. cit., p. 80.

${ }^{591}$ Conforme o Decreto Nacional argentino n. 1273/92, que regulamenta a Lei n. 24.059, sobre Segurança Interior, "se entiende por fuerzas de seguridad a la Prefectura Naval Argentina y a la Gendarmería Nacional" (art. $\left.1^{\circ}\right)$.

592 Claudia B. Moscato de Santamaria, El agente encubierto..., ob. cit., p. 01.

${ }^{593}$ Note-se que o artigo $6^{\circ}$ da Lei n. 24.424, que incorpora o artigo 31 bis à Lei n. 23.737, apenas faz referência, em seu texto, aos "agentes de las fuerzas de seguridad em actividad", excluindo a possibilidade de serem infiltrados os agentes das forças policias (Polícia Federal argentina e polícias provinciais). No entanto, de acordo com Carlos Enrique Edwards, considerando-se os antecedentes parlamentares da referida Lei, a vontade do legislador não é a de excluir das atividades de infiltrados as forças policiais: "aunque la Lei . 24.424 solamente mencione expressamente a las fuerzas de seguridad, ello no es óbice, efectuando uma interpretación coherente y sistemática, para que también puedan ser agentes encubiertos los integrantes de las fuerzas policiales e, incluso, de um organismo administrativo como la Aduana. Uma exégesis que limitara la pisibilidad de designación del agente encubierto solamente entre los integrantes de las fuerzas de seguridad, verdaderamente atentaria contra la eficácia com que se pretende dotar al sistema penal argentino em la represión del narcotráfico, ya que tal hermenêutica prescindiria de las agencias policiales que han demonstrado, em los innumerables casos em que participaron, contar com recursos humanos y técnicos para luchar exitosamente contra este tipo de delincuencia”. (Carlos Enrique Edwards, El arrepentido..., ob. cit., p. 64). 
sobre os delitos que comete enquanto está infiltrado. ${ }^{594}$ Conforme determina a lei argentina, não são punidos os delitos necessários para que se desenvolva a infiltração, desde que sejam consequiência necessária da atuação do agente, e que o agente tenha sido compelido a cometê-los, não tendo restado a ele outra alternativa. ${ }^{595}$ Ainda, de se notar que a Lei não oferece impunidade total, mas exclui da escusa absolutória aqueles delitos que coloquem em perigo a vida ou a integridade física de outrem, ou que impliquem em grave sofrimento físico ou moral de terceiros, nos termos do artigo $7^{\circ}$ da Lei n. 24.424, que incorpora o artigo 31, 3 à Lei n. $23.737^{596} 597$

Frente à necessidade de utilização da informação obtida pelo agente infiltrado em juízo, a Lei 24.424 prevê que tal informação seja considerada elemento de prova, e que o infiltrado seja ouvido em juízo como testemunha. ${ }^{598}$ Nesses casos, a mesma Lei prevê, ainda, uma série de medidas de proteção ao agente, o qual necessariamente terá de se expor para ser ouvido em juízo. ${ }^{599}$

Interessante notar que, com o objetivo de garantir ainda mais segurança ao sigilo das informações relativas às identidades dos agentes infiltrados, a lei argentina prevê, em seu artigo $10^{600}$, a criminalização da conduta do

\footnotetext{
${ }^{594}$ Carlos Enrique Edwards, El arrepentido..., ob. cit., p. 89.

${ }^{595}$ Carlos Enrique Edwards, El arrepentido..., ob. cit., p. 89.

596 “Art. $7^{\circ}$-- Incorpórase como art. 31 ter a la ley 23.737, el siguiente:
}

Art. 31 ter. -- No será punible el agente encubierto que como consecuencia necesaria del desarrollo de la actuación encomendada, se hubiese visto compelido a incurrir en un delito, siempre que éste no implique poner en peligro cierto la vida o la integridad física de una persona o la imposición de un grave sufrimiento físico o moral a otro.

Cuando el agente encubierto hubiese resultado imputado en un proceso, hará saber confidencialmente su carácter al juez interviniente, quien en forma reservada recabará la pertinente información a la autoridad que corresponda.

Si el caso correspondiere a las previsiones del primer párrafo de este artículo, el juez lo resolverá sin develar la verdadera identidad del imputado".

${ }^{597}$ Carlos Enrique Edwards, El arrepentido..., ob. cit., p. 90.

${ }^{598}$ Carlos Enrique Edwards, El arrepentido..., ob. cit., p. 77.

${ }^{599}$ Carlos Enrique Edwards, El arrepentido..., ob. cit., p. 76.

600 “Art. 10. -- Incorpórase como art. 31 sexies a la ley 23.737, el siguiente:

Art. 31 sexies. El funcionario o empleado público que indebidamente revelare la real o nueva identidad de un agente encubierto o, en su caso, la nueva identidad o el domicilio de un testigo o imputado protegido, será reprimido con prisión de dos a seis años, multa de diez mil a cien mil pesos e inhabilitación absoluta perpetua. 
funcionário público que indevidamente revelá-las ou que, por imprudência, negligência ou inobservância de seus deveres funcionais, permitir que outros tomem conhecimento de tais dados. ${ }^{601}$

Por fim, note-se que a jurisprudência argentina distingue o agente provocador do agente infiltrado, uma vez que considera a atuação do agente provocador (a instigação de delitos) ilícita, e "en los supuestos de procedencia de la figura del agente encubierto, previstos en el art. $6^{\circ}$ de dicha ley [a Lei n. 24.424], siempre se refiere a hipótesis lícitas, en ningún momento a la inducción o instigación a la comisión de ningún tipo de delito, como sucede con el comportamiento de agente provocador". ${ }^{62}$ A mais moderna doutrina argentina considera, em verdade, que a atuação do agente provocador é ato punível, como sustenta Enrique Bacigalupo: “No cabe duda de que el comienzo doloso de ejecución del provocado (instigado) por el agente provocador (instigador) es antijurídico y que, por lo tanto, están cumplidos los presupuestos de la instugación punible incusive desde el punto de vista de la teoria de la participación en lo ilícito, pues la tentativa, que por regla comete el provocado, es ya um ilícito punible. El agente provocador es por tanto punible”. ${ }^{603}$

\subsection{Espanha.}

$\mathrm{Na}$ Espanha, a infiltração de agentes em organizações criminosas é regulada pela Ley Organica n. 5/1999, de 13 de janeiro, que introduziu o artigo 282 bis na Ley de Enjuiciamiento Criminal ${ }^{604} \cdot{ }^{605}$ Esta mesma Lei introduziu no

El funcionario o empleado público que por imprudencia, negligencia o inobservancia de los deberes a su cargo, permitiere o diere ocasión a que otro conozca dicha información, será sancionado con prisión de uno a cuatro años, multa de un mil a treinta mil pesos e inhabilitación especial de tres a diez años".

${ }^{601}$ Rodrigo Garcia Vilardi e Wagner Roby Gídaro, O crime organizado e o terrorismo na Argentina. In: Crime organizado - aspectos processuais. São Paulo: Revista dos Tribunais, 2009, p. 80.

${ }^{602}$ Carlos Enrique Edwards, El arrepentido..., ob. cit., p. 58.

${ }^{603}$ Enrique Bacigalupo, Manual de Derecho Penal, parte geral. Bogotá: Temis-Ilanud, 1984, p. 208.

604 “Artículo 282 bis.

1. A los fines previstos en el artículo anterior y cuando se trate de investigaciones que afecten a actividades propias de la delincuencia organizada, el Juez de Instrucción competente aspectos processuais. São Paulo: Revista dos Tribunais, 2009, p. 80. 
país - de maneira "instrumental"606 , diga-se - a definição de organização criminosa, presente no artigo 282 bis, 4, do mesmo diploma legal. ${ }^{607}$

${ }^{604}$ Carlos Enrique Edwards, El arrepentido..., ob. cit., p. 58.

${ }^{604}$ Enrique Bacigalupo, Manual o el Ministerio Fiscal dando cuenta inmediata al Juez, podrán autorizar a funcionarios de la Policía Judicial, mediante resolución fundada y teniendo en cuenta su necesidad a los fines de la investigación, a actuar bajo identidad supuesta y a adquirir y transportar los objetos, efectos e instrumentos del delito y diferir la incautación de los mismos. La identidad supuesta será otorgada por el Ministerio del Interior por el plazo de seis meses prorrogables por períodos de igual duración, quedando legítimamente habilitados para actuar en todo lo relacionado con la investigación concreta y a participar en el tráfico jurídico y social bajo tal identidad.

La resolución por la que se acuerde deberá consignar el nombre verdadero del agente y la identidad supuesta con la que actuará en el caso concreto.

La resolución será reservada y deberá conservarse fuera de las actuaciones con la debida seguridad.

La información que vaya obteniendo el agente encubierto deberá ser puesta a la mayor brevedad posible en conocimiento de quien autorizó la investigación. Asimismo, dicha información deberá aportarse al proceso en su integridad y se valorará en conciencia por el órgano judicial competente".

${ }^{605}$ Note-se que mesmo antes da regulamentação legal pela Lei n. 5/1999, a maior parte da doutrina e da jurisprudência já sustentava a admissibilidade do agente infiltrado, considerando que sua atuação estaria abrigada por uma causa de exclusão de ilicitude, nomeadamente o cumprimento do dever. Nesse sentido, já haviam se manifestado tanto o Supremo Tribunal Espanhol (acórdãos de 4 de março de 1992 e 2 de julho de 1993) quanto o Tribunal Constitucional Espanhol (acórdão de 21 de fevereiro de 1983). (Isabel Oneto, $O$ agente infiltrado..., ob. cit., p. 99).

${ }^{606}$ Isabel Sánchez García de Paz sustenta que a definição de crime organizado apresentada é "instrumental" pois o objetivo maior da referida Lei era instituir, no ordenamento jurídico espanhol, a figura do agente infiltrado, e não elaborar uma definição de organização criminosa em si. Tal definição, dessa maneira, estaria relegada a um segundo plano. (Isabel Sánchez García de Paz, La criminalidad organizada..., ob. cit., p. 31). Para outros autores, como Sílvia Planet Robles, no entanto, a Lei 5/1999 é, ainda assim, dotada de extrema importância, uma vez que foi responsável pela positivação do conceito de crime organizado na legislação espanhola, até então carente de uma regulamentação legal da figura. (Sílvia Planet Robles, Políticas de seguridad y prevención en el estado español en materia de delincuencia organizada. La seguridad en la sociedad del riesgo: un debate abierto. Barcelona: Atelier, 2003, p. 171). De toda sorte, como tivemos já a oportunidade de salientar em conjunto com Marco Antônio Pinheiro Machado Cogan, a tipificação merece críticas, vez que não existe diferenciação entre as condutas de participação em organização criminosa e de formação de quadrilha ou bando, ficando a nota distintiva apenas por conta do rol de crimes apresentados na lei, cuja prática teria o condão de transformar determinada conduta de associação delitiva em criminalidade organizada. (Maria Jamile José e Marco Antônio Pinheiro Machado Cogan, Crime organizado e terrorismo na Espanha. In: Crime organizado - aspectos processuais. São Paulo: Revista dos Tribunais, 2009, p. 125).

607 "Art. 282 bis. 4. A los efectos señalados en el apartado 1 de este artículo, se considerará como delincuencia organizada la asociación de tres o más personas para realizar, de forma permanente o reiterada, conductas que tengan como fin cometer alguno o algunos de los delitos siguientes:

Delito de secuestro de personas previsto en los artículos 164 a 166 del Código Penal.

Delitos relativos a la prostitución previstos en los artículos 187 a 189 del Código Penal.

Delitos contra el patrimonio y contra el orden socioeconómico previstos en los artículos 237, 243, 244, 248 y 301 del Código Penal.

Delitos relativos a la propiedad intelectual e industrial previstos en los artículos 270 a 277 del Código Penal.

Delitos contra los derechos de los trabajadores previstos en los artículos 312 y 313 del Código Penal.

Delitos de tráfico de especies de flora o fauna amenazada previstos en los artículos 332 y 334 del Código Penal. 
No país, diferentemente do que ocorre no Brasil, a infiltração em organizações criminosas pode ser realizada não apenas por agentes estatais, mas também por pessoas estranhas aos quadros da polícia, sendo suficiente, para que se caracterize a figura do agente infiltrado, o fato de atuar sob o controle do Estado. ${ }^{608}$ No entanto, em todos os casos, a infiltração deve sempre ser precedida de autorização, a qual pode ser outorgada tanto pelo Juiz Instrutor competente quanto pelo representante do Ministério Público, conforme determina o artigo legal supramencionado. Tal como na legislação alemã, contudo, em casos de urgência a ante a impossibilidade de obter-se a autorização tanto judicial quanto ministerial, admite-se que se inicie a infiltração sem autorização, desde que esta seja suprida logo após o seu início. $^{609}$

Não dispõe a lei espanhola, tal qual a brasileira, acerca do período de duração da infiltração. Assim sendo, tal tarefa tem ficado a cargo da doutrina, a qual tem entendido que um prazo de seis meses é razoável para a medida, sem prejuízo de eventual prorrogação. ${ }^{610}$ A doutrina aceita, ainda, a possibilidade de o Ministério Público ou o juiz, com o objetivo de manter sob controle a atividade dos agentes infiltrados, solicitarem informações periódicas sobre o desenvolvimento da investigação. $^{611}$

Com relação à responsabilidade penal do agente infiltrado, a Espanha optou, assim como a maior parte dos países que adotam a infiltração como

Delito de tráfico de material nuclear y radiactivo previsto en el artículo 345 del Código Penal.

Delitos contra la salud pública previstos en los artículos 368 a 373 del Código Penal.

Delito de falsificación de moneda previsto en el artículo 386 del Código Penal.

Delito de tráfico y depósito de armas, municiones o explosivos previsto en los artículos 566 a 568 del Código Penal.

Delitos de terrorismo previstos en los artículos 571 a 578 del Código Penal.

Delitos contra el Patrimonio Histórico previstos en el artículo 2.1.e de la Ley Orgánica 12/1995, de 12 de diciembre, de represión del contrabando”.

${ }^{608}$ Juan Muñoz Sanches, El agente provocador. Valencia: Tirant lo Blanch, 1995, p. 41.

${ }^{609}$ Isabel Oneto, $O$ agente infiltrado..., ob. cit., p. 99.

${ }^{610} \mathrm{Na}$ realidade, o artigo 282 bis, 1, determina que a identidade fictícia será outorgada ao agente pelo prazo de seis meses, prorrogáveis por períodos de igual duração. Como o agente apenas pode atuar de maneira infiltrada se dispuser de uma identidade fictícia, a doutrina espanhola presume que este é, também, o período pelo qual pode ser autorizada a operação.

${ }^{611}$ Maria Dolores Delgado García, El agente encubierto: técnicas de investigación. Problemática y legislación comparada. In: La criminalidad organizada ante la Justicia. Sevilla: Universidad de Sevilla, 1996, p. 71. 
técnica de investigação, por criar para a hipótese uma causa de escusa absolutória - a qual, no caso espanhol, está ligada fortemente ao princípio da proporcionalidade. Assim, o agente infiltrado apenas está isento de responsabilidade penal se ficar demonstrado que suas ações foram conseqüência necessária da investigação na qual estava envolvido e que eram proporcionais aos fins que buscavam. Ainda, deve restar claro que não foi o próprio agente que provocou o delito, conforme estabelece o artigo 282, bis, 5, da Ley de Enjuiciamiento Criminal. ${ }^{612}$

$$
\text { Note-se que a doutrina e jurisprudência espanhola }
$$

distinguem o agente infiltrado do agente provocador, embora não exista no país disposição legal acerca do tema. Via de regra, considera-se que os agentes infiltrados, diferentemente dos provocadores, atuam dentro dos limites delineados pela Constituição, e que suas condutas estão justificadas pelo cumprimento dos deveres relativos aos seus cargos. ${ }^{613}$ Situação diferente seria a do agente provocador: a doutrina majoritária espanhola entende que ele deve responder penalmente pelo delito que incita o provocado a cometer. ${ }^{614}$

\subsection{Estados Unidos da América. A entrapment defense.}

Nos Estados Unidos da América (EUA), diversos diplomas legais já formularam definições de crime organizado. A primeira, em 1968, foi a Omnibus Crime Control and Safe Streets Act (Public Law 90-351) $)^{615}$, seguida por

612 “Artículo 282 bis. 5. El agente encubierto estará exento de responsabilidad criminal por aquellas actuaciones que sean consecuencia necesaria del desarrollo de la investigación, siempre que guarden la debida proporcionalidad con la finalidad de la misma y no constituyan una provocación al delito."

${ }^{613}$ Isabel Oneto, $O$ agente infiltrado..., ob. cit., p. 99.

${ }^{614}$ Claudia B. Moscato de Santamaria, El agente encubierto..., ob. cit., p. 17.

${ }^{615}$ Em seu Title I, Part F (6), esta Lei assim determina: “Organized crime means the unlawful activities of members of a highly organized, disciplened association engaged in supplying illegal goods and services, including but not limited to gambling, prostitution, loan sharking, narcotics, labour racketeering, and other unlawful activities of members of such associations". (João Davin, A criminalidade organizada transnacional..., ob. cit., p. 91). 
outras - dentre elas a Racketeering Influenced and Corrupt Organizations Act (RICO) (Public Law 91-452), de 1970 ${ }^{616} 617$

É possível afirmar que este é o país no qual a infiltração de agentes ganhou maior notoriedade. De fato, esse é o meio de investigação de provas mais empregado pelos organismos policiais norte-americanos, mormente o Drug Enforcement Administration (DEA) ${ }^{618}$, e beneficia-se da utilização de sofisticado aparato de espionagem. ${ }^{619}$

$\mathrm{O}$ uso dos agentes infiltrados (undercover agents, em inglês) é conhecido no país desde o século XVIII, tendo se desenvolvido bastante desde então, mormente devido ao fenômeno de urbanização norteamericano, somado às mudanças observadas nas leis penais e nas condutas criminais. ${ }^{620}$ Hoje, são admitidas, nos EUA, a compra de substâncias proibidas para serem usadas nas operações encobertas (principalmente nas modalidades flash roll e buy and bust, as mais

616 Nesta lei, define-se crime organizado como “atividades lucrativas não-honestas e criminosas (racketeering activities), como é o caso do tráfico ilícito de entorpecentes, exigindo, contudo, a incidência de elementos que as caracterizam como crime organizado: repetição e continuidade, conexões reveladoras de padrões de conduta, realização por um grupo de pessoas que repartem o mesmo objetivo e utilização de ciol6encia ou intimidação para a obtenção de vantagens ilegais”. (Fábio Ramazzini Bechara e Luís Fernando de Moraes Manzano, Crime organizado e terrorismo nos Estados Unidos da América. In: Crime organizado - aspectos processuais. São Paulo: Revista dos Tribunais, 2009, pp. 155-156). É possível afirmar que esta lei inaugurou um novo enfoque no que tange às questões relacionadas à criminalidade dita organizada. (João Davin, A criminalidade organizada transnacional..., ob. cit., p. 91).

${ }^{617}$ Fábio Ramazzini Bechara e Luís Fernando de Moraes Manzano, Crime organizado..., ob. cit., pp. 155156.

${ }^{618}$ Rafael Pacheco, Crime organizado..., ob. cit., p. 108.

${ }^{619}$ Fábio Ramazzini Bechara e Luís Fernando de Moraes Manzano, Crime organizado..., ob. cit., p. 161.

${ }^{620}$ Mario Daniel Montoya, Informantes..., ob. cit., p. 82. O autor sustenta que a origem dos agentes infiltrados no país pode ser atribuída à Pinkerton Agency, encarregada de infitrar-se nas quadrilhas do Oeste americano. Após a Guerra Civil Americana, o Post Office e o Treasury Department empregaram detetives infiltrados para combater os roubos aos Correios e as falsificações. Em 1930, o FBI (Federal Bureau of Investigation) passou a utilizar esta técnica. (Mario Daniel Montoya, Informantes..., ob. cit., p. 83). 
comuns $^{621}$, e sting operation), e mesmo a constituição de empresas fictícias pelos infiltrados no âmbito de uma investigação criminal ${ }^{622}{ }^{623}$

De acordo com a legislação norte-americana, são funções do agente infiltrado: apurar o papel das pessoas envolvidas nas atividades criminosas, bem como os lugares em que tais atividades se desenvolvem; e identificar as fontes usadas pelos membros da organização criminosa. ${ }^{624}$

De se notar que, no país, admite-se que a infiltração seja realizada não apenas por agentes públicos, mas também por particulares - mais precisamente, por informantes ${ }^{625}$-, sob a justificativa de que a infiltração destes seria mais bem aceita pelos grupos criminosos investigados do que a de policiais tentando se

${ }^{621}$ Michael D. Lyman e Gary W. Potter, Organized crime. New Jersey: Pearson Prentice Hall, 2007, p. 423. Os autores destacam que estes métodos mais comuns - mormente o chamado buy and bust -, embora detenham a vantagem de propiciar a rápida prisão dos traficantes sem a necessidade de muitos gastos, apresentam problemas, pois expõem os agentes infiltrados a um grande risco, além de tornar sua identidade conhecida em um breve período de tempo. Além disso, é questionável o sucesso destes métodos para a infiltração de agentes em níveis mais altos das organizações criminosas.

${ }^{622}$ Dois casos bastante conhecidos da opinião pública americana servem para demonstrar as proporções assumidas pelas operações infiltradas nos EUA. Em 1979, agentes infiltrados americanos se fizeram passar por investidores árabes e constituíram, no Oriente Médio, a empresa Abdul Enterprises Limited. A operação tinha por objetivo "testar a lealdade" de alguns políticos, oferecendo-lhes a oportunidade de praticar atos de corrupção. Sob a identidade falsa, os agentes contataram os investigados e ofereceram-lhes benefícios e facilidades relacionados a investimentos no mercado imobiliário. A operação foi bem-sucedida e resultou em 25 prisões, dentre senadores, deputados e advogados. (Isabel Oneto, $O$ agente infiltrado..., ob. cit., pp. 105106). Já nos anos 1990, no auge do combate americano aos cartéis colombianos de cocaína, uma equipe do Drug Enforcement Administration (DEA), conhecida como Group 93 e liderada pelo policial especialista em infiltrações Jerry Speziale, infiltrou-se no comércio colombiano de cocaína, com a ajuda de um informante brasileiro chamado Paul Lir Alexander. Os policiais fizeram-se passar por transportadores de cocaína, criando, para isso, uma infra-estrutura milionária, que compreendia empresas de fachada e pistas de pouso e abastecimento de aviões no meio da selva em diversos países, os quais incluíam Guatemala, Costa Rica e Brasil. Como resultado, lograram apreender, ao longo de alguns anos, mais de dois mil quilos de cocaína e três milhões de dólares. Foram conseqüência desta operação, também, as prisões dos principais líderes dos cartéis colombianos, inclusive de Pablo Escobar - o qual acabou fugindo da cadeia, sendo posteriormente morto pela polícia colombiana em Medellín. (Jerry Speziale e Mark Seal, Without a badge - Undercover in the world's deadliest criminal organization. New York: Kensington Books, 2003).

${ }^{623}$ Isabel Oneto, $O$ agente infiltrado..., ob. cit., p. 105.

${ }^{624}$ Fábio Ramazzini Bechara e Luís Fernando de Moraes Manzano, Crime organizado..., ob. cit., p. 161.

${ }^{625}$ Nos EUA, o informante é definido como "qualquer pessoa que fornece informação sobre um crime, mas que não seja a parte acusatória, vítima ou testemunha. Informantes podem ser cidadãos conscienciosos ou criminosos atrozes que buscam algum benefício em troca de seu depoimento”. (Fábio Ramazzini Bechara e Luís Fernando de Moraes Manzano, Crime organizado..., ob. cit., p. 162). 
passar por criminosos. ${ }^{626}$ De toda sorte, a maioria das leis estaduais exige ordem judicial para a realização da infiltração. ${ }^{627}$

O cometimento de delitos por parte do infiltrado no decorrer da operação é admitido pela práxis norte-americana, desde que o agente conte com autorização prévia de seu superior. Contudo, são impostos alguns limites à sua atuação, ficando vedada: a obtenção de benefícios pessoais por meio dos delitos que vier a cometer; a vulneração de direitos constitucionais, salvo mediante prévia autorização; o oferecimento ou recebimento de favores sexuais no exercício de suas funções; a intimidação ou ameaça de investigados; e, por fim, a provocação de crimes pelos investigados. ${ }^{628}$

Dada a amplitude da utilização da infiltração de agentes nos EUA, desenvolveu-se ali, como em nenhum outro local do mundo, a doutrina acerca da defesa utilizada contra esta prática policial, denominada entrapment defense, a qual representou verdadeira revolução na problemática da provocação ao crime e da infiltração policial como um todo. ${ }^{629}$ Entrapment - palavra que pode ser traduzida, de maneira literal, como "apanhar na armadilha"630 - pode ser definida, conforme já o fez a jurisprudência americana, como "the conception and planning of an offense by an officer, and his procurement of its commission by one who would not have perpetrated it except for the trickery, persuasion or fraud of the officer". 631

A entrapment defense tem sua origem na jurisprudência americana ante a necessidade de impor limites à atividade dos agentes encarregados de pôr em prática a Lei Seca, os quais, por meio de métodos encobertos, induziam as pessoas a violá-la. $^{632}$ Seu desenvolvimento, no entanto, foi relativamente lento nos Estados Unidos $^{633}$, uma vez que as Cortes do país tendiam a aceitar a idéia geral de que "um crime

\footnotetext{
${ }^{626}$ Fábio Ramazzini Bechara e Luís Fernando de Moraes Manzano, Crime organizado..., ob. cit., p. 162.

${ }^{627}$ Fábio Ramazzini Bechara e Luís Fernando de Moraes Manzano, Crime organizado..., ob. cit., p. 162.

${ }^{628}$ Fábio Ramazzini Bechara e Luís Fernando de Moraes Manzano, Crime organizado..., ob. cit., p. 162.

${ }^{629}$ Manuel Augusto Alves Meireis, $O$ regime..., ob. cit., p. 95.

${ }^{630}$ Manuel Augusto Alves Meireis, O regime..., ob. cit., p. 95.

${ }^{631}$ Isabel Oneto, $O$ agente infitlrado..., ob. cit., p. 40.

${ }^{632}$ Claudia B. Moscato de Santamaría, El agente encubierto..., ob. cit., p. 09.

${ }^{633}$ Isabel Oneto, $O$ agente infitlrado..., ob. cit., p. 38.
} 
era sempre um crime, a despeito das circunstâncias que cercaram seu cometimento". ${ }^{634}$ As primeiras referências a ela aparecem nos casos Whittier, em 1878, Woo Wai, em 1915, e Casey v. U.S., em 1928 - neste último, lê-se na declaração de voto do juiz Brandeis: "The government may set decoys to entrap criminals, but it may not provoke or create a crime and then punish the criminal, its creature". 635 A entrapment defense, no entanto, foi verdadeiramente consagrada apenas no caso Sorrels v. U.S., em 1932, no qual é proferido o primeiro acórdão em instância superior reconhecendo a tese, como se lê: "that defendant had no previous disposition to commit it but was an industrious, law-abiding citizen, and that the agent lured the defendant, otherwise innocent, to its commission by repeated and persistent solicitation in which he succeeded by taking advantage of the sentiment aroused by reminiscences of their experiences as companions in arms in the World War". 636 A partir dos anos 1950 e 1960, a entrapment defense torna-se abundante na jurisprudência americana, acompanhando o crescimento em massa no consumo de drogas, para só então começar a ser abordada pela doutrina. ${ }^{637}$

Existem dois modelos para a entrapmente defense. O mais adotado pela doutrina norte-americana, inclusive pelo American Law Institute, e que figura no Model Penal Code do país, é o objetivo, que se prende mais à atuação da polícia do que à eventual predisposição do investigado para cometer o crime. ${ }^{638}$ Segundo este modelo, deve ser analisada a intervenção dos agentes policiais, cujos efeitos no investigado são averiguados em função do seu impacto hipotético sobre o homem médio respeitador da lei ("normally law-abiding person"). Desse modo, cabe ao órgão julgador "verificar se no decurso da ação policial foram cumpridas as regras mínimas para que um indivíduo normalmente respeitador das leis não seja levado a cometer um crime que nunca cometeria se não fosse a intervenção policial. Se assim for, mesmo que o indivíduo seja tecnicamente culpado, ele não será punido por se considerar que a ação da polícia foi objetivamente intolerável". ${ }^{639}$ Já o outro modelo, conhecido por subjetivo, menos utilizado, afere o cabimento da entrapment defense a partir de dois aspectos,

\footnotetext{
${ }^{634}$ Mario Daniel Montoya, Informantes..., ob. cit., p. 96.

${ }^{635}$ Isabel Oneto, $O$ agente infitlrado..., ob. cit., p. 38.

${ }^{636}$ Isabel Oneto, $O$ agente infiltrado..., ob. cit., pp. 38-39.

${ }^{637}$ Isabel Oneto, $O$ agente infiltrado..., ob. cit., p. 42.

${ }^{638}$ Isabel Oneto, $O$ agente infitlrado..., ob. cit., p. 44.

${ }^{639}$ Isabel Oneto, $O$ agente infitlrado..., ob. cit., p. 44.
} 
repartindo, portanto, o ônus da prova: primeiramente, procura comprovar que o projeto criminoso teve a sua origem na ação da polícia; e, após, busca averiguar se o investigado não teria já uma predisposição para delinqüir. ${ }^{640}$

Note-se que a entrapment defense se aplica apenas em situações de provocação policial, e tem dois objetivos primordiais: evitar que os cidadãos sejam "persuadidos" pelo próprio Estado a cometer crimes, e impedir que sejam toleradas práticas policiais excessivas, ainda que o investigado seja culpado. ${ }^{641}$ De se observar que esse mecanismo, apesar de tomar a forma de uma defesa do acusado, não configura um direito deste, mas sim uma norma que cumpre uma função de profilaxia e prevenção das condutas policiais, não sendo aplicável aos casos em que a provocação não partiu de um agente da polícia. ${ }^{642}$

\subsection{França.}

Alterações recentes operadas no Código de Processo Penal Francês (Code de Procédure Pénale) foram responsáveis pela inserção, neste diploma legal, de diversos meios de investigação de provas utilizados para o combate ao crime organizado e ao terrorismo no país, dentre estes, o agente infiltrado, previsto em seus artigos 706-81 a 706-87.

A lei francesa exige autorização prévia para a efetivação da medida. Tal autorização deve ser motivada, sob pena de nulidade, e deve fixar desde logo o prazo de duração da infiltração, o qual não pode ser superior a quatro meses. ${ }^{643}$

\footnotetext{
${ }^{640}$ Isabel Oneto, $O$ agente infitlrado..., ob. cit., p. 43.

${ }^{641}$ Isabel Oneto, $O$ agente infiltrado..., ob. cit., p. 37.

${ }^{642}$ Isabel Oneto, $O$ agente infiltrado..., ob. cit., p. 37.

643 “Art. 706-83. A peine de nullité, l'autorisation donnée en application de l'article 706-81 est délivrée par écrit et doit être spécialement motivée.

Elle mentionne la ou les infractions qui justifient le recours à cette procédure et l'identité de l'officier de police judiciaire sous la responsabilité duquel se déroule l'opération.

Cette autorisation fixe la durée de l'opération d'infiltration, qui ne peut pas excéder quatre mois. L'opération peut être renouvelée dans les mêmes conditions de forme et de durée. Le magistrat qui a autorisé l'opération peut, à tout moment, ordonner son interruption avant l'expiration de la durée fixée.
} 
Dependendo da fase processual em que se justificar a medida, a autorização pode ser outorgada por um membro do Ministério Público ou pelo Juiz de Instrução, devendo, quem autorizá-la, exercer o controle da operação. ${ }^{644}$ De toda forma, deve o agente reportar ao magistrado competente todas as atividades desenvolvidas ao longo da infiltração. ${ }^{645}$

Com relação à prática de condutas típicas pelo infiltrado no decurso da operação, o referido Código apresenta, em seu artigo 706-82 ${ }^{646}$, um rol de atos que podem ser praticados pelo agente sem implicar sua responsabilidade penal, desde que este o faça com o fim único de viabilizar a investigação.

Também no sistema francês o agente infiltrado é diferenciado do provocador, sendo igualmente proibida a provocação do delito. Porém, é importante destacar que a jurisprudência francesa admite que os agentes infiltrados possam conduzir o investigado ao cometimento do delito, "desde que haja prova suficiente de que a intenção criminosa era anterior à intervenção policial. A prova dessa intenção criminosa pode sustentar-se em escutas telefônicas, padrões de deslocações observados por agentes policiais ou em condenações anteriores por tráfico de droga". 647

Note-se, por fim, que, à semelhança do que ocorre no ordenamento Argentino, também na legislação francesa é criminalizado o ato daquele que revelar a identidade do agente infiltrado, sendo as penas aumentadas se da

L'autorisation est versée au dossier de la procédure après achèvement de l'opération d'infiltration."

${ }^{644}$ Elisa Pires da Cruz Reale Caçapava e Fernanda Regina Vilares, Crime organizado e terrorismo na França. In: Crime organizado - aspectos processuais. São Paulo: Revista dos Tribunais, 2009, p. 192.

${ }^{645}$ Isabel Oneto, $O$ agente infiltrado..., ob. cit., p. 100.

646 “Art. 706-82. Les officiers ou agents de police judiciaire autorisés à procéder à une opération d'infiltration peuvent, sur l'ensemble du territoire national, sans être pénalement responsables de ces actes :

$1^{\circ}$ Acquérir, détenir, transporter, livrer ou délivrer des substances, biens, produits, documents ou informations tirés de la commission des infractions ou servant à la commission de ces infractions ;

$2^{\circ}$ Utiliser ou mettre à disposition des personnes se livrant à ces infractions des moyens de caractère juridique ou financier ainsi que des moyens de transport, de dépôt, d'hébergement, de conservation et de télécommunication.

L'exonération de responsabilité prévue au premier alinéa est également applicable, pour les actes commis à seule fin de procéder à l'opération d'infiltration, aux personnes requises par les officiers ou agents de police judiciaire pour permettre la réalisation de cette opération”.

${ }^{647}$ Isabel Oneto, $O$ agente infiltrado..., ob. cit., p. 100. 
revelação acarretar violência ou morte do agente, seu cônjuge, filhos ou ascendentes diretos. ${ }^{648}$

\subsection{Portugal.}

Embora também não exista, em Portugal definição jurídica de crime organizado, é possível afirmar que a legislação do país em matéria de meios de investigação de prova específicos para este tipo de criminalidade é bastante avançada e equilibrada, buscando a eficácia sem restrição exagerada e sem descuidar da observância às normas de garantia. ${ }^{649}$

Nesse sentido, a infiltração de agentes encontra-se prevista na Lei portuguesa n. 101/2001, de 25 de agosto. Conforme dispõe o artigo $1^{\circ}$, n. 1 , deste diploma legal, a infiltração de agentes tem fins não apenas de investigação, mas também de prevenção criminal $^{650}$, ou seja, serve tanto para averiguar a existência de um crime, de seus autores e recolher provas pertinentes ${ }^{651}$, quanto para evitar crimes futuros $^{652}$. O artigo $2^{\circ}$ do mesmo diploma legal ${ }^{653}$ apresenta um rol de crimes em que o

648 “Art. 706-84. L'identité réelle des officiers ou agents de police judiciaire ayant effectué l'infiltration sous une identité d'emprunt ne doit apparaître à aucun stade de la procédure.

La révélation de l'identité de ces officiers ou agents de police judiciaire est punie de cinq ans d'emprisonnement et de 75000 euros d'amende.

Lorsque cette révélation a causé des violences, coups et blessures à l'encontre de ces personnes ou de leurs conjoints, enfants et ascendants directs, les peines sont portées à sept ans d'emprisonnement et à 100000 euros d'amende.

Lorsque cette révélation a causé la mort de ces personnes ou de leurs conjoints, enfants et ascendants directs, les peines sont portées à dix ans d'emprisonnement et à 150000 euros d'amende, sans préjudice, le cas échéant, de l'application des dispositions du chapitre Ier du titre II du livre II du code pénal".

${ }^{649}$ Silvio César Arouck Gemaque e Luciana Russo, Crime organizado em Portugal. In: Crime organizado aspectos processuais. São Paulo: Revista dos Tribunais, 2009, pp. 280-281.

${ }^{650}$ Manuel Monteiro Guedes Valente, Manuel João Alves e Fernando Gonçalves, O novo regime jurídico..., ob. cit., p. 27.

${ }^{651}$ Manuel Monteiro Guedes Valente, Manuel João Alves e Fernando Gonçalves, O novo regime jurídico..., ob. cit., p. 29.

${ }^{652}$ Manuel Monteiro Guedes Valente, Manuel João Alves e Fernando Gonçalves, O novo regime jurídico..., ob. cit., p. 28.

653 “Artigo $2^{o}$. Âmbito de aplicação.

As acções encobertas são admissíveis no âmbito da prevenção e repressão dos seguintes crimes: 
recurso ao agente infiltrado, enquanto meio de investigação de prova, é admissível, sendo tal enumeração legal taxativa. ${ }^{654}$

Não há, à semelhança do que ocorre na Espanha e nos EUA, necessidade de que o agente infiltrado seja policial, devendo apenas atuar sob o controle da Policia Judiciária do país ${ }^{655}$, conforme dispõe o artigo $1^{\circ}$, n. 2 , de sua Lei n. 101/2001. ${ }^{656}$ Contudo, quando realizada no decorrer do Inquérito Policial, a medida deve ser sempre precedida por autorização do representante do Ministério Público, o

a) Homicídio voluntário, desde que o agente não seja conhecido;

b) Contra a liberdade e contra a autodeterminação sexual a que corresponda, em abstracto, pena superior a 5 anos de prisão, desde que o agente não seja conhecido, ou sempre que seja expressamente referidos ofendidos menores de 16 anos ou outros incapazes;

c) Relativos ao tráfico e viciação de veículos furtados ou roubados;

d) Escravidão, seqüestro e rapto ou tomada de reféns;

e) Organizações terroristas e terrorismo;

f) Captura ou atentado à segurança de transporte por ar, água, caminho-de-ferro ou rodovia a que corresponda, em abstracto, pena igual ou superior a 8 anos de prisão;

g) Executados com bombas, granadas, matérias ou engenhos explosivos, armas de fogo e objectos armadilhados, armas nucleares, químicas ou radioactivas;

h) Roubo em instituições de crédito, repartições da Fazenda Pública e correios;

i) Associações criminosas;

j) Relativos ao tráfico de estupefacientes e de substâncias psicotrópicas;

l) Branqueamento de capitais, outros bens ou produtos;

m) Corrupção, peculato e participação econômica em negócio e tráfico de infuências;

n) Fraude na obtenção ou desvio de subsídio ou subvenção;

o) Infracções económico-financeiras cometidas de forma organizada ou com recurso à tecnologia informática;

p) Infracções económico-financeiras de dimensão internacional ou transnacional;

q) Contrafação de moeda, títulos de créditos, valores selados, selos e outros valores equiparados ou a respectiva passagem;

r) Relativos ao mercado de valores mobiliários".

${ }^{654}$ Manuel Monteiro Guedes Valente, Manuel João Alves e Fernando Gonçalves, O novo regime jurídico..., ob. cit., p. 43.

${ }^{655}$ Manuel Monteiro Guedes Valente, Manuel João Alves e Fernando Gonçalves, O novo regime jurídico..., ob. cit., p. 27.

656 “Artigo 1". 2- Consideram-se acções encobertas aquelas que sejam desenvolvidas por funcionários de investigação criminal ou por terceiro actuando sob o controlo da Política Judiciária para prevenção ou repressão dos crimes indicados nesta lei, com ocultação da sua qualidade e identidade”. 
qual deve, então, comunicar obrigatoriamente o Juiz de Instrução, de acordo com o artigo $3^{\circ}$, n. 3 , do mesmo diploma legal ${ }^{657}$.

Também não há, na lei portuguesa, menção explícita ao período de duração da infiltração. Contudo, o artigo $3^{\circ}$, n. 1, da Lei n. 101/2001 ${ }^{658}$ procura orientar o juiz e o representante do Ministério Público na determinação do prazo da infiltração, ao estabelecer critérios de adequação e de proporcionalidade para a medida. É necessário, ainda, que a Polícia Judiciária apresente relatório de suas atividades à autoridade judiciária competente, dentro do prazo máximo de quarenta e oito horas após o término da infiltração, conforme disposto no artigo $3^{\circ}$, n. 6, do mesmo texto legislativo. ${ }^{659}$

A mesma lei autoriza a prática de delitos por parte do agente no decorrer da infiltração, nos termos de seu artigo $6^{\circ}{ }^{660}$ Assim, a lei isenta o agente de responsabilidade pela prática de atos preparatórios ou mesmo de execução em co-participação com os demais integrantes da organização criminosa em que ele encontra-se infiltrado, desde que tal atuação não corresponda à instigação criminosa nem à autoria mediata do delito, e desde que guarde uma relação de proporcionalidade com a finalidade da infiltração. ${ }^{661}$ Ainda, a doutrina ressalta que tal colaboração delituosa - bem como a prática de atos de execução - só pode ser isenta de pena se a atividade criminosa já estiver em curso. ${ }^{662}$ Conforme afirmam Manuel Monteiro Guedes Valente, Manuel João Alves e Fernando Gonçalves, "não é tolerável que o agente

657 “Artigo 3". 3- A realização de uma acção encoberta no âmbito do inquérito depende de prévia autorização do competente magistrado do Ministério Público, sendo obrigatoriamente comunicada ao juiz. de instrução e considerando-se a mesma validada se não for proferido despacho de recusa nas setenta e duas horas seguintes".

658 “Artigo $3^{\circ} .1$ - As acções encobertas devem ser adequadas aos fins de prevenção e repressão criminais identificados em concreto, nomeadamente a descoberta de material probatório, e proporcionais quer àquelas finalidades quer à gravidade do crime em investigação”.

659 “Artigo $3^{\circ}$. 6 - A Polícia Judiciária fará o relato da intervenção do agente encoberto à autoridade judiciária competente no prazo máximo de quarenta e oito horas após o termo daquela”.

660 “Artigo $6^{\circ} .1$ - Não é punível a conduta do agente encoberto que, no âmbito de uma acção encoberta, consubstancie a prática de actos preparatórios ou de execução de uma infracção e da autoria mediata, sempre que guarde a devia proporcionalidade com a finalidade da mesma.

2 - Se for instaurado procedimento criminal por acto ou actos praticados ao abrigo do disposto na presente lei, a autoridade judiciária competente deve, logo que tenha conhecimento de tal facto, requerer informação à autoridade judiciária que emitiu a autorização a que se refere o n. 3 do artigo $3^{\text {o" }}$.

${ }^{661}$ Texto da lei.

${ }^{662}$ Manuel Monteiro Guedes Valente, Manuel João Alves e Fernando Gonçalves, $O$ novo regime jurídico..., ob. cit., p. 38. 
infiltrado adopte uma conduta de impulso ou instigação dessa atividade, sob pena de se converter num verdadeiro agente provocador. Em suma, não pode o agente infiltrado, ou agente investigador, como também é designado, determinar a prática do crime. A sua atividade não pode ser formativa do crime, mas apenas informativa" ${ }^{663}$

Note-se, ainda, que o ordenamento jurídico português diferencia, além do agente infiltrado e do agente provocador, também uma terceira figura o agente encoberto. Esse tipo de agente corresponde a uma figura da polícia criminal ou particular que, sem revelar sua qualidade ou identidade, freqüenta os lugares relacionados com a criminalidade (bares, cafés, lojas, e outros lugares abertos ao público), com a finalidade de identificar - e eventualmente deter - possíveis suspeitos da prática de crimes. ${ }^{664}$ Esta figura, no entanto, se distingue das demais por sua absoluta passividade em relação à decisão criminosa ${ }^{665}$ - o agente encoberto não determina a prática de qualquer crime nem tenta conquistar a confiança dos investigados ${ }^{666}$. Em outras palavras, sua presença nos lugares relacionados com a prática de crimes é totalmente indiferente para determinar o rumo dos acontecimentos delituosos. ${ }^{667}$ A doutrina portuguesa considera a sua atuação totalmente lícita e legalmente admissível ${ }^{668}$, podendo ser a prova assim obtida ser aceita e livremente valorada pelo magistrado ${ }^{669}$.

Interessante notar, por fim, que o legislador português, em atitude vanguardista, e procurando atender às diferentes necessidades investigativas apresentadas pelo crime organizado - de natureza eminentemente transnacional -, permitiu a atuação, no país, de agentes infiltrados de outros Estados. É o que prevê a Lei n.

\footnotetext{
${ }^{663}$ Manuel Monteiro Guedes Valente, Manuel João Alves e Fernando Gonçalves, O novo regime jurídico..., ob. cit., p. 38.

${ }^{664}$ Manuel Monteiro Guedes Valente, Manuel João Alves e Fernando Gonçalves, O novo regime jurídico..., ob. cit., pp. 40-41.

${ }^{665}$ Manuel Augusto Alves Meireis, $O$ regime..., ob. cit., p. 192.

${ }^{666}$ Manuel Monteiro Guedes Valente, Manuel João Alves e Fernando Gonçalves, O novo regime jurídico..., ob. cit., p. 41.

${ }^{667}$ Manuel Augusto Alves Meireis, $O$ regime..., ob. cit., p. 192.

${ }^{668}$ Manuel Monteiro Guedes Valente, Manuel João Alves e Fernando Gonçalves, O novo regime jurídico..., ob. cit., p. 41.

${ }^{669}$ Manuel Monteiro Guedes Valente, Manuel João Alves e Fernando Gonçalves, O novo regime jurídico..., ob. cit., p. 41.
} 
104/2001, na alteração operada ao artigo 160-B, 1 a 3, da Lei de Cooperação Judiciária Internacional em Matéria Penal. ${ }^{670}$

670 “Artigo160. ${ }^{\circ}-B$.

1 - Os funcionários de investigação criminal de outros Estados podem desenvolver acções encobertas em Portugal, com estatuto idêntico ao dos funcionários de investigação criminal portugueses e nos demais termos da legislação aplicável.

2 - A actuação referida no número anterior depende de pedido baseado em acordo, tratado ou convenção internacional e da observância do princípio da reciprocidade.

3 - A autoridade judicial competente para a autorização é o juiz do Tribunal Central de Instrução Criminal, sob proposta do magistrado do Ministério Público junto do Departamento Central de Investigação e Acção Penal (DCIAP)”. 


\section{CAPÍTULO 5 - SUGESTÕES LEGISLATIVAS}

\subsection{As alterações legislativas desejadas e seus motivos.}

Conforme anteriormente mencionado, entendemos que a regulamentação jurídica destinada atualmente à infiltração de agentes nos delitos relacionados à criminalidade organizada está muito longe do ideal. ${ }^{671} \mathrm{O}$ dispositivo legal que define a figura - a Lei ${ }^{\circ} 9.034 / 95$, em seu artigo $2^{\circ}, \mathrm{V}$ - mostra-se vago e falho, nada dispondo acerca do procedimento que devem obedecer a sua autorização e implementação.

Como resultado, temos, hoje, um instituto jurídico que, a despeito da sua importância para o combate ao crime organizado, encontra-se parcamente regulado, apresentando falhas que o colocam à beira da inutilidade - ou, senão, cuja utilização, em função da falta de limites, ameaça direitos e garantias fundamentais.

Assim sendo, acreditamos que uma regulamentação abrangente e responsável da matéria é imprescindível para que a infiltração de agentes possa ser empregada sem colocar em risco as liberdades individuais garantidas por nossa Constituição da República.

\footnotetext{
${ }^{671}$ Existem autores - com os quais, no entanto, não concordamos - que entendem não haver necessidade de nova regulamentação legal da figura do agente infiltrado, sendo o texto legal existente suficiente para sua implementação. Nesse sentido, Damásio E. de Jesus e Fábio Ramazzini Bechara, os quais chegam a sustentar que as omissões legislativas são intencionais: "Apesar da redação lecunosa da lei que introduziu a figura do agente infiltrado, não há necessidade de regulamentação dela por meio de outra espécie normativa. A principal exigência para sua aplicação, que constitui o standard mínimo para o deferimento da medida, está expressamente reconhecida. Assim, há as exigências de se tratar de associação criminosa e de decisão judicial fundamentada. Não se fez qualquer alusão quanto ao procedimento ou ao prazo da medida. É possivel, contudo, afirmar a intencionalidade dessa omissão legislativa, uma vez que a determinação do prazo deve se orientar pela necessidade do caso concreto e pelo bom senso e responsabilidade do juiz. (...) $E^{\prime}$ razoável admitir, ainda, que essas omissões legais possam ser perfeitamente supridas por meio do emprego da analogia da Lei $n$. 9.296/96, que regulamenta o procedimento das interceptações telefônicas”. (Damásio E. de Jesus e Fábio Ramazzini Bechara, Agente infiltrado: reflexos penais e processuais. Revista Juz Vigilantibus, 11 de outubro de 2005. Artigo disponível no endereço eletrônico: http://jusvi.com/artigos/17889, em 07 de outubro de 2009). Contudo, tendo em vista os diversos direitos fundamentais - dos investigados e de terceiros - que, como visto, podem acabar por sofrer restrições devido ao emprego deste meio de investigação de provas, acreditamos que uma regulamentação legal mais precisa é imprescindível para evitar abusos e conferir segurança às relações jurídicas e sociais.
} 


\subsection{O Projeto de Lei n. 3.731/1997 do Senado Federal (n. 67/1996 da Câmara dos Deputados). ${ }^{672}$}

Procurando atender à necessidade premente de regulamentação jurídica adequada para o instituto do agente infiltrado, foi proposto na Câmara dos Deputados o Projeto de Lei n. 67/1996, o qual pretende definir e regulamentar os meios de prova e procedimentos investigatórios destinados à prevenção e repressão dos crimes praticados por organizações criminosas. ${ }^{673}$ Após aprovado nesta Casa, este Projeto de Lei foi remetido ao Senado Federal, onde recebeu o número 3.731/1997. ${ }^{674}$

Em sua seção II, artigos 9 a 13, este Projeto de Lei traz uma regulação detalhada das atividades do agente infiltrado, como se vê:

\footnotetext{
“SUBSTITUTIVO DA CÂMARA AO PROJETO DE LEI DO SENADO N. 67, DE 1996 (n. 3.731/1997, naquela Casa).
}

Dispõe sobre as organizações criminosas, os meios de obtenção da prova e o procedimento criminal.

O Congresso Nacional decreta:

SEÇÃO II

\section{Da infiltração de agentes}

\footnotetext{
${ }^{672}$ Note-se que o projeto de lei relativo ao crime organizado mais recente - o Projeto de Lei n. 150/2006, aprovado na Comissão de Constituição e Justiça em novembro de 2007 e atualmente na pauta do Plenário para análise final do Senado - não prevê a infiltração de agentes como meio de investigação de prova para os delitos ligados à delinqüência organizada. Assim sendo, estuda-se o Projeto de Lei n. 3.731/1997 por ser o mais recente dentre os que trazem a previsão do agente infiltrado.

${ }^{673}$ Gustavo Henrique Righy Ivahi Badaró, Relatório de acompanhamento de projetos de leis - IBCCrim. Artigo disponível no endereço eleônico: http://www.ibccrim.org.br/site/estudosPesquisas/estudosProjetos.php?tipo=selProjetos\&id=166\#, em 23 de novembro de 2009.

${ }^{674}$ Gustavo Henrique Righy Ivahi Badaró, Relatório..., ob. cit..
} 
Art. $9^{o}$. A infiltração de agentes de polícia em tarefas de investigação, conduzida pelos órgãos especializados pertinentes, será precedida de circunstanciada e motivada autorização judicial, que estabelecerá seus limites, após a manifestação do Ministério Público.

$\S 1^{\circ}$. Não será admitida a infiltração se não houver indícios de infração penal e se a prova puder ser produzida por outros meios disponíveis.

$\S 2^{\circ}$. A infiltração não poderá exceder o prazo de três meses, sem prejuízo de eventuais renovações, desde que comprovada sua necessidade.

$\S 3^{\circ}$. Findo o prazo previsto no $\S 2^{o}$, a autoridade policial deverá apresentar relatório circunstanciado ao juiz competente, que imediatamente cientificará o Ministério Público.

$\$ 4^{o}$. A autoridade judicial e o Ministério Público poderão requisitar relatório da atividade de infiltração antes do prazo de três meses.

Art. 10. A representação da autoridade policial para a infiltração de agentes conterá a demonstração da necessidade desta, o alcance das tarefas dos agentes e os nomes ou apelidos das pessoas investigadas, quando possível, além de autorização do Chefe de Polícia.

Art. 11. O pedido de infiltração será sigilosamente distribuído, de forma a não conter informações que possam indicar a operação a ser efetivada ou identificar o agente que será infiltrado.

$\S 1^{\circ}$. As informações da operação de infiltração serão dirigidas diretamente ao juiz a quem recair a distribuição, que decidirá no prazo de vinte e quatro horas, remetendo-se em seguida os autos para a Corregedoria-Geral de Justiça, a qual zelará pelo seu sigilo. 
$\$ 2^{\circ}$. O acesso aos autos será reservado apenas ao juiz, ao Ministério Público e à autoridade policial, para garantia do sigilo das investigações.

$\S 3^{\circ}$. Os autos contendo as informações da operação de infiltração serão apensados ao processo criminal ao término da instrução probatória, quando serão disponibilizados à defesa, naquilo em que disserem respeito ao fato criminoso da ação penal, assegurando-se a preservação da identidade do agente e aplicando-se, no que couber, o art. 36 desta Lei ${ }^{675}$.

Art. 12. O agente que não guardar, na sua atuação, a devida proporcionalidade com a finalidade da investigação responderá pelos excessos praticados.

Art. 13. São direitos do agente:

I - recusar a atuação infiltrada;

II - ter sua identidade alterada durante a infiltração, aplicando-se no que couber, o disposto no art. $9^{\circ}$ da Lei $n .9 .807$, de

675 “Art. 36. O pedido para a preservação da identidade será autuado em apartado, em procedimento sigiloso, ouvido o Ministério Público, no prazo de vinte e quatro horas, decidindo o juiz em igual prazo.

$\S 1^{o}$. Se o pedido resultar de representação da autoridade policial, será encaminhado ao juízo contendo nome, endereço e demais dados de qualificação do beneficiário, que passará a ser identificado nos autos por meio de código correspondente ao seu nome.

$\$ 2^{\circ}$. O Ministério Público fará constar da denúncia o código correspondente à pessoa que tenha sua identidade preservada.

$\S 3^{\circ}$. Deferido o pedido na fase processual, o juiz passará a identificar a vítima, a testemunha ou o acusadocolaborador por meio do código referido no $\$ 1^{\circ}$.

$\$ 4^{\circ}$. Os mandados judiciais serão elaborados em separado, individualizados, garantindo que o nome e o endereço das pessoas preservadas sejam conhecidos apenas pelo oficial de justiça por ocasião de seu cumprimento.

$\$ 5^{\circ}$. Cumprindo o mandado, será juntada aos autos certidão do oficial de justiça da qual não conste o nome $e$ endereço da vítima, da testemunha ou do acusado-colaborador, indicando apenas o código de identificação correspondente.

$\$ 6^{\circ}$. Os mandados judiciais cumpridos serão entregues pelo oficial de justiça ao escrivão do cartório judicial, que procederá à juntada no procedimento instaurado para a preservação da identidade.

$\$ 7^{\circ}$. Os autos do pedido de preservação ficarão sob a guarda da Corregedoria-Geral de Justiça, podendo a eles ter acesso apenas o Juiz, o Ministério Público e a autoridade judicial”. 
13 de julho de 1999676, bem como usufruir das medidas de proteção a testemunhas;

$$
\text { III - ter seu nome, sua qualificação e demais }
$$

informações pessoais preservados durante a investigação e o processo criminal, salvo se houver decisão judicial em contrário;

$$
I V \text { - não ter sua identidade revelada, nem ser }
$$

fotografado ou filmado pelos meios de comunicação”.

Consideramos tal Projeto de Lei bastante satisfatório no que se refere à regulamentação das atividades do agente infiltrado, uma vez que vincula a medida à autorização, devidamente motivada, de um Juiz competente (artigo $9^{\circ}$, caput); veda a infiltração caso não existam indícios de infração penal (artigo $9^{\circ}$, parágrafo primeiro), caso a prova possa ser produzida por outros meios (princípio da subsidiariedade - artigo $9^{\circ}$, parágrafo primeiro), ou caso a prova perquirida não seja de necessidade vital para a persecução penal do delito in casu (artigo 10); determina um prazo razoável pelo qual pode perdurar a medida (artigo $9^{\circ}$, parágrafo segundo), assim como um mecanismo de controle do juiz competente sobre o infiltrado (artigo $9^{\circ}$, parágrafos terceiro e quarto); prevê o procedimento sigiloso dos autos da infiltração policial (artigo 11, parágrafos

676 “Artigo $9^{\circ}$. Em casos excepcionais e considerando as características e gravidade da coação ou ameaça, poderá o conselho deliberativo encaminhar requerimento da pessoa protegida ao juiz competente para registros públicos objetivando a alteração de nome completo.

$\S 1^{\circ}$ - A alteração de nome completo poderá estender-se às pessoas mencionadas no $\S 1^{\circ}$ do artigo $2^{\circ}$ desta Lei, inclusive aos filhos menores, e será precedida das providências necessárias ao resguardo de direitos de terceiros.

$\S 2^{o}$ - O requerimento será sempre fundamentado e o juiz ouvirá previamente o Ministério Público, determinando, em seguida, que o procedimento tenha rito sumaríssimo e corra em segredo de justiça.

$\S 3^{o}$ - Concedida a alteração pretendida, o juiz determinará na sentença, observando o sigilo indispensável à proteção do interessado:

I - a averbação no registro original de nascimento da menção de que houve alteração de nome completo em conformidade com o estabelecido nesta Lei, com expressa referência à sentença autorizatória e ao juiz que a exarou e sem a aposição do nome alterado;

II - a determinação aos órgãos competentes para o fornecimento dos documentos decorrentes da alteração;

III - a remessa da sentença ao órgão nacional competente para o registro único de identificação civil, cujo procedimento obedecerá às necessárias restrições de sigilo.

$\S 4^{o}$ - O conselho deliberativo, resguardado o sigilo das informações, manterá controle sobre a localização do protegido cujo nome tenha sido alterado.

$\S 5^{\circ}$ - Cessada a coação ou ameaça que deu causa à alteração, ficará facultado ao protegido solicitar ao juiz competente o retorno à situação anterior, com a alteração para o nome original, em petição que será encaminhada pelo conselho deliberativo e terá manifestação prévia do Ministério Público”. 
primeiro, segundo e terceiro); estabelece a necessidade de proporcionalidade na atuação do agente infiltrado, prevendo a sua responsabilidade nos casos em que sua atuação for desproporcional à finalidade da investigação (artigo 12); e, finalmente, regulamenta os termos da ocultação da identidade e da proteção do infiltrado (artigo 13).

A nosso ver, este Projeto de Lei representa um grande avanço em termos de regulamentação legal da infiltração de agentes ${ }^{677}$, deixando a desejar apenas no tocante à prática de condutas típicas pelo agente no decurso da infiltração. Contudo, sua tramitação nas Casas Legislativas vem se mostrando lenta, não tendo sido observado qualquer progresso em sua evolução desde 2003, quando foi remetido ao Senado Federal.

${ }^{677}$ O mesmo Projeto de Lei n. 3.731/1997 do Senado Federal também traz, em seu Capítulo I, artigo $1^{\circ}$, proposta bastante interessante para a definição legal de crime organizado - que, como visto, corresponde a outra grave lacuna da Lei n. 9034/1995. A definição sugerida - baseada em um conjunto de características, somadas a um rol de condutas típicas a serem praticadas pelo grupo organizado - é a seguinte:

"Art. $1^{o}$. Considera-se organização criminosa a associação de três ou mais pessoas, por meio de entidade jurídica ou não, estruturada de forma estável, visando a obter, direta ou indiretamente, vantagem de qualquer natureza, para a prática de:

I - tráfico ilícito de substâncias entorpecentes ou produtos que causam dependência física ou psíquica;

II - terrorismo e seu financiamento;

III - contrabando ou tráfico ilícito de armas, munições, explosivos, ou materiais destinados à sua produção;

IV-extorsão mediante seqüestro;

$V$ - crime contra a Administração Pública;

VI - crime contra o sistema financeiro nacional;

VII - crime contra a ordem econômica e tributária;

VIII - exploração de jogos de azar cumulada com outros delitos;

IX - crime contra instituições financeiras, empresas de transporte de valores ou cargas e a receptação de bens ou produtos que constituam proveito auferido por esta prática criminosa;

$X$ - lenocínio ou tráfico de mulheres;

XI - tráfico internacional de criança ou adolescente;

XII - lavagem de dinheiro, ocultação de bens, direitos e valores;

XIII - tráfico ilícito de tecidos, órgãos ou partes do corpo humano;

$X I V$ - homicídio qualificado;

$X V$ - falsificação, adulteração ou alteração de produto destinado a fins terapêuticos ou medicinais;

XVI - crime contra o meio ambiente e o patrimônio cultural;

XVII - outros crimes previstos em tratados ou convenções internacionais de que o Brasil seja parte”. 


\subsection{Nossa proposta de regulamentação legal.}

Diante do exposto, tomamos a liberdade de elaborar um modelo de Projeto de Lei contendo as disposições legais que entendemos necessárias para que seja possível lançar mão da infiltração de agentes - meio de investigação de provas de grande eficácia nos delitos relacionados à criminalidade organizada - sem que sejam ofendidas as liberdades individuais garantidas constitucionalmente:

PROJETO DE LEI N. ${ }^{\circ}$ , DE DEZEMBRO DE 2009. ${ }^{678}$

Dispõe sobre o emprego da infiltração de agentes como meio de investigação de provas nos delitos ligados à criminalidade organizada.

Art. $\mathbf{1}^{\circ}$. Considera-se como agente infiltrado o policial integrante das Polícias Civil ou Federal ${ }^{679}$ que, com o fim exclusivo de obter elementos de prova para investigação criminal e instrução processual penal, infiltra-se na organização criminosa de que são membros os investigados, simulando a condição de um integrante.

$\S 1^{\circ}$. Para os fins desta lei, considera-se como organização criminosa qualquer grupo estruturado de três ou mais integrantes, atuando estável e concertadamente, com a finalidade de obter, direta ou indiretamente, qualquer tipo de benefício econômico ou material, por meio do cometimento de crimes graves, sendo assim

\footnotetext{
${ }^{678}$ Sugestão legislativa elaborada nos termos do Decreto n. 4.176, de 28 de março de 2002.

${ }^{679}$ Suprimimos aqui a referência feita no artigo $2^{\circ}$, V, da Lei 9.034/95 aos agentes de inteligência pois, como visto supra (item 3.3.1), tal disposição é inconstitucional. Ainda, entendemos por bem especificar os tipos de policiais (Civis e Federais, ou seja, apenas os integrantes da polícia repressiva que, de acordo com o artigo 144 de nossa Constituição da República, podem atuar como infiltrados, por ter entre suas atribuições a investigação de delitos.
} 
considerados os atos que constituam delitos puníveis com pena de privação de liberdade cujo máximo seja não inferior a quatro anos. ${ }^{680}$

$\S 2^{\circ}$. O agente infiltrado apenas poderá ser utilizado como meio de investigação de prova em crimes cometidos por membros de organizações criminosas ou a elas direitamente relacionados ${ }^{681}$, os quais já sejam objeto de Inquérito Policial ou Processo Penal ${ }^{682}$.

$\S 3^{\circ}$. A infiltração policial não será admitida caso a prova pretendida possa ser obtida por outros meios disponíveis. ${ }^{683}$

Art. $\mathbf{2}^{\mathbf{0}}$. A requisição para a infiltração de agentes deve ser formulada:

\section{I - pela autoridade policial, no curso do Inquérito Policial;}

II - pelo representante do Ministério Público, no curso do Inquérito Policial e durante a instrução processual penal.

Parágrafo único. A requisição para a infiltração de agentes conterá:

\footnotetext{
${ }^{680}$ Utilizamos, nesta proposta legislativa, a definição de organização criminosa elaborada pela Convenção de Palermo, ratificada pelo Brasil em 12 de março de 2004 (Decreto n. 5.015). Note-se que, como visto, por força do princípio da legalidade, a existência de uma definição consistente de organização criminosa é imprescindível para a viabilidade da infiltração de agentes como meio de investigação de provas.

${ }^{681}$ Sendo, como visto, um meio de investigação de prova excepcional, que implica restrição a diversos direitos fundamentais garantidos por Constituição da República, a infiltração de agentes deve ser empregado apenas em casos especialíssimos, como o crime organizado, em que os meios de investigação de provas tradicionais já não se mostram eficazes. Assim sendo, a previsão para sua utilização nos delitos ligados às organizações criminosas é taxativa, não aceitando alargamentos.

682 A exigência de que haja um Inquérito Policial ou processo penal previamente instaurado vem da necessidade de existência de indícios (e não meras suspeitas, note-se) de materialidade e de autoria do delito antes que se instale a infiltração de agentes, para se evitar uma "caça às bruxas". A idéia, aqui, é evitar que o agente infiltrado acabe por levar a uma desnaturalização do processo penal, convertendo-o em um instrumento de prevenção do delito, ao invés de dar causa à aplicação do Direto Penal. Assim, para que o Juiz autorize a infiltração de agentes, deve-se pressupor a existência de uma investigação instaurada. (Mariângela Lopes Neistein, $O$ agente infiltrado..., ob. cit., pp. 97-99).

${ }^{683}$ Como visto, o agente infiltrado apenas poderá ser usado como meio de investigação de prova "em última instância, atento ao princípio da proporcionalidade, após a utilização de outros meios de prova, dado o seu caráter subsidiário para apuração da infração penal cometida por organizações criminosas”. José Antônio Pinheiro Aranha Filho, Implicações..., ob. cit.).
} 
I - a demonstração da sua indispensabilidade para a apuração da infração penal, bem como da inadequação dos demais meios de investigação de prova no caso concreto;

II - a descrição detalhada do objeto da investigação, inclusive com a indicação e qualificação dos investigados, salvo impossibilidade manifesta, devidamente justificada;

$$
\text { III - a identificação e qualificação do agente infiltrado e a }
$$
especificação do alcance das suas tarefas durante o período de infiltração.

Art. 3o. A infiltração policial deve ser precedida de autorização do Magistrado competente ${ }^{684}$, após ser ouvido o representante do Ministério Público.

Parágrafo único. A decisão que autoriza a infiltração deve ser motivada $^{685}$, sob pena de nulidade ${ }^{686}$.

\footnotetext{
${ }^{684}$ Como visto, "por ser atividade ofensiva a diversas garantias constitucionais, é preciso que [os agentes infiltrados] atuem somente com autorização específica do Juiz fiscalizador da investigação. Sem a devida autorização, a atividade se mostrará ilícita". (Mariângela Lopes Neistein, $O$ agente infiltrado..., ob. cit., p. 45). A autorização judicial, assim, é indispensável e deve ser vista como a mais importante e eficaz forma de assegurar o controle judicial sobre a atividade do agente infiltrado. (Eduardo Araújo da Silva, Crime organizado..., ob. cit., p. 87). Trata-se, em verdade, de um corolário de um Estado Democrático de Direito: a necessidade de que qualquer medida supressora de direitos passe pela apreciação do órgão jurisdicional, o qual analisará a legalidade do ato e o preenchimento dos requisitos legais para o deferimento da medida. (José Antônio Pinheiro Aranha Filho, Implicações..., ob. cit..) É, também, a primeira condição de validade das provas obtidas pelo agente infiltrado: "a validade das provas recolhidas dependerá da observância prática dos limites da autorização; se o agente da autoridade investigar para além do que lhe foi permitido, sejam factos, pessoas, ou situações, as provas não poderão ser atendidas pois não se consideram abrangidas pela autorização que é conditio sine qua non da exclusão da ilicitude de tais práticas". (Manuel Augusto Alves Meireis, O regime..., ob. cit., p. 137).
}

Com relação à autorização, ainda, é importante notar que cremos incabível a possibilidade de a autorização para a infiltração ser outorgada pelo representante do Ministério Público, como ocorre, por exemplo, na legislação portuguesa (artigo $3^{\circ}, 3$, da Lei n. 101/2001), uma vez que se trata de medida restritiva de direitos fundamentais, cabendo ao Magistrado a atividade de garantidor, bem como de supervisor nas investigações. (Fernando Gascón Inchausti, Infiltración policial..., ob. cit., p. 117). Assim sendo, "para uma melhor supervisão, a fim de que haja uma efetiva garantia do respeito às normas constitucionais, a autorização para a atuação do agente infiltrado deve ser concedida por Juiz". (Mariângela Lopes Neistein, $O$ agente infiltrado..., ob. cit., p. 107).

${ }^{685}$ Conforme sustenta Mariângela Lopes Neistein, “a motivação significa que a decisão deve fazer menção expressa às razões que, no caso concreto, tornam necessária a utilização da infiltração de policiais nas organizações. Deve o Juiz fundamentar, na sua decisão, a necessidade da infiltração naquele caso concreto. Não bastará a indicação da investigação envolvendo crimes nos quais se permita a atuação do agente infiltrado. A decisão deverá indicar o motivo, no caso concreto, que torna imprescindível a utilização desse meio investigatório". (Mariângela Lopes Neistein, $O$ agente infiltrado..., ob. cit., p. 142). 
Art. $4^{\mathbf{0}}$. A infiltração poderá ser autorizada por um prazo máximo de seis meses ${ }^{687}$, prorrogável por igual período, uma única vez, devendo a decisão de prorrogação ser motivadas.

$\S 1^{\circ}$. O policial infiltrado deverá enviar ao Juiz competente, bimestralmente, relatório completo de suas atividades. ${ }^{688}$

$\S 2^{\circ}$. Caso o Juiz competente entenda que a medida está se desviando de seus fins, pode, a qualquer momento, desde que motivadamente, após ouvido o representante do Ministério Público, interrompê-la. ${ }^{689}$

Art. $5^{\circ}$. O procedimento da infiltração policial seguirá em autos apartados, dos quais se preservará o sigilo. A estes autos terão acesso apenas o Juiz competente, o representante do Ministério Público e a autoridade policial. ${ }^{690}$

${ }^{686}$ Disposição semelhante na legislação francesa (artigo 706-83 do Code de Procédure Pénale).

${ }^{687}$ A determinação de um prazo de duração para a infiltração é de fundamental importância para que o direito fundamental à intimidade do investigado, bem como das pessoas de seu convívio social, sofra a mínima restrição possível. Entendemos, à semelhança da legislação espanhola (artigo 282 bis, 1, do Codigo de Enjuiciamiento Criminal) que seis meses é o prazo ideal para que a medida seja eficaz, uma vez que, devido à própria natureza deste meio investigativo, prazos muito curtos inviabilizariam a obtenção de resultados.

${ }^{688}$ Os relatórios periódicos são de importância fundamental para que o Magistrado competente possa exercer controle sobre a infiltração, inclusive para verificar se os fins pretendidos com a medida estão sendo alcançados e se o agente está exercendo seu papel com a devida lisura e sem excessos. Conforme explicita Mariângela Lopes Neistein, "tal previsão se faz necessária para evitar abusos advindos da atuação do agente infitlrado. (...) a atividade é bastante sedutora e os agentes podem passar a atuar em favor das organizações, quando se virem beneficiados, principalmente financeiramente. Um controle superior poderia, em tese, diminuir o risco, ou mesmo impedir que o infiltrado passe a agir contra os interesses da sociedade, uma vez que sua atividade também é controlada. Este controle se faz necessário também para que a autoridade possa avaliar a necessidade ou não da continuidade das investigações. Tal tarefa não pode ser exclusiva do agente infiltrado. Este policial deve consultar a autoridade para discutir sobre a continuidade da atuação encoberta”. (Mariângela Lopes Neistein, $O$ agente infiltrado..., ob. cit., p. 127). É necessário, porém, que se observe a ressalva feita por Carlos Enrique Edwards: "obviamente que no es imprescindible que esta información obtenida sea suministrada en persona por el agente encubierto al juez de la causa, ya que tal circunstancia podría implicar revelar su identidad, corriendo el serio riesgo de ser descubierto; por ello, la fuerza de seguridade o policial a la que pertenza el agente encubierto, dispondrá la manera más segura para contactarse con el agente y recibir esa información, la que luego será comunicada al juez. interviniente”. (Carlos Enrique Edwards, El arrepentido..., ob. cit., p. 81).

${ }^{689}$ Entendemos de extrema importância que se reserve ao Magistrado competente a faculdade de interromper as atividades investigativas infiltradas assim que entender necessário, quando verificar que a medida não mais se justifica no caso concreto, que já foram adquiridas provas suficientes, que não há indicação do suposto cometimento do delito (Mariângela Lopes Neistein, $O$ agente infiltrado..., ob. cit., p. 152), ou, ainda que a atuação do agente infiltrado desvirtuou-se.

${ }^{690}$ A necessidade do sigilo apresenta duplo fundamento: a garantia da eficácia da investigação (uma vez que haveria perda de todo o objeto da investigação caso o investigado tomasse conhecimento da existência de um agente infiltrado na organização criminosa) e a salvaguarda da integridade física do infiltrado, o qual pode sofrer represálias caso sua condição venha à tona; e, também, a preservação da intimidade dos investigados. 
Parágrafo único. Os autos contendo as informações relativas à operação de infiltração somente serão disponibilizados à defesa:

I - no caso de infiltração em sede de Inquérito Policial, imediatamente antes do relatório da autoridade, quando os autos da infiltração policial serão apensados aos autos Inquérito;

II - no caso de infiltração no decorrer da instrução processual, no momento da conclusão do processo ao Juiz para o despacho decorrente do disposto nos artigos $406^{691}$ e $396^{692}$ do Código de Processo Penal.

Art. $6^{\circ}$. Após o término da infiltração, em um prazo máximo três dias, o agente infiltrado, em conjunto com a autoridade policial, fará um relatório da operação infiltrada, o qual deve ser juntado nos autos da infiltração. ${ }^{693}$

Art. $\mathbf{7}^{\mathbf{0}}$. A atuação infiltrada dos agentes de polícia se dará sob identidade fictícia. ${ }^{694}$

(Mariângela Lopes Neistein, $O$ agente infiltrado..., ob. cit., p. 111). Tão importante é a manutenção do segredo acerca da real identidade do agente infiltrado que as legislações francesa (artigo 706-84 do Code de Procédure Pénale) e argentina (artigo 10 da Lei n. 24.424) impõem graves penas de multa e de restrição de direitos àquele que revelar a sua identidade de maneira indevida, culposa ou dolosamente.

691 “Art. 406. O juiz, ao receber a denúncia ou a queixa, ordenará a citação do acusado para responder a acusação, por escrito, no prazo de 10 (dez) dias.

$\S 1^{\circ}$. O prazo previsto no caput desde artigo será contado a partir do efetivo cumprimento do mandado ou do comparecimento, em juízo, do acusado ou de defensor constituído, no caso de citação inválida ou por edital.

$\S 2^{\circ}$. A acusação deverá arrolar testemunhas, até o máximo de 8 (oito), na denúncia ou na queixa.

$\S 3^{\circ}$. Na resposta, o acusado poderá argüir preliminares e alegar tudo que interesse à sua defesa, oferecer documentos e justificações, especificar as provas pretendidas e arrolar testemunhas, até o máximo de 8 (oito), qualificando-as e requerendo sua intimação, quando necessário”.

692 “Art. 396. Nos procedimentos ordinário e sumário, oferecida a denúncia ou queixa, o juiz, se não a rejeitar liminarmente, recebê-la-a e ordenará a citação do acusado para responder à acusação, por escrito, no prazo de 10 (dez) dias.

Parágrafo único. No caso de citação por edital, o prazo para a defesa começará a fluir a partir do comparecimento pessoa do acusado ou do defensor constituído”.

${ }^{693}$ Cremos que esta disposição, presente na legislação portuguesa (artigo 3º, 6, da Lei n.101/2001) é de extrema importância para que tanto o Juiz quanto, posteriormente, o Ministério Público e a defesa, possam exercer controle sobre as atividades do agente infiltrado; e, também, para que a defesa possa exercer o contraditório, ainda que de maneira diferida.

${ }^{694}$ Conforme ressaltam Manuel Monteiro Guedes Valente, Manuel João Alves e Fernando Gonçalves, “ $a$ identidade fictícia é uma manifestação formal e material da preocupação de segurança exigível quanto ao agente encoberto, cujo o risco que o agente corre não é comum, mas sim anormal (...), pelo que se impõe por necessidade e exigibilidade que os agentes encobertos actuem sob identidade fictícia". (Manuel Monteiro Guedes Valente, Manuel João Alves e Fernando Gonçalves, O novo regime jurídico..., ob. cit., p. 102). 
$\S 1^{\circ}$. A identidade fictícia é atribuída pela autoridade policial e deve perdurar por toda a duração da infiltração, quer no exercício concreto da investigação, quer em todas as atividades sociais em que considerar necessário para manutenção de seu disfarce. ${ }^{695}$

$\S 2^{\circ}$. O despacho da autoridade policial que atribui a identidade fictícia é sigiloso e deve incluir a referência à verdadeira identidade do agente encoberto $^{696}$, incluindo seu nome e qualificação.

$\S 3^{\circ}$. Após outorgada ao agente sua identidade fictícia, passará ele a ser identificado nos autos por meio de código correspondente ao seu nome.

$\S 4^{\circ}$. Caso haja a necessidade de o agente infiltrado ser ouvido como testemunha na fase de instrução probatória, sua oitiva será feita de maneira a preservar o sigilo de sua identidade, imagem e dados pessoais ${ }^{697}$, aplicando-se, no que couber, e a critério do Juiz competente, as medidas previstas no artigo $7^{\circ}$ da Lei $n$. $9.807 / 1999^{698}$.

${ }^{695} \mathrm{O}$ emprego da identidade fictícia pelo agente, enquanto perdurar a infiltração, mesmo quando não está efetivamente exercendo atividades investigatórias, é uma circunstância que pode ser necessária para evitar a descoberta de sua real identidade, que pode ocorrer a qualquer instante. É comum o relato feito por agentes infiltrados no sentido de estarem em constante estado de stress devido à possibilidade de serem reconhecidos na rua por qualquer pessoa de suas relações sociais antigas, ainda que a operação decorra em locais distantes do seu verdadeiro passado. E, se os investigados duvidam de sua identidade, isso pode custar-lhes a vida, o que os obriga a uma rigorosa coerência quanto à história de suas novas "personagens". (Isabel Oneto, $O$ agente infiltrado..., ob. cit., pp. 86-87). Por isso mesmo, a legislação portuguesa apresenta disposição semelhante à que aqui criamos, no sentido de possibilitar ao agente a utilização de sua identidade fictícia no convívio social, mesmo quando não se encontra em efetivas atividades investigatórias, pelo período que perdurar a operação (artigo $5^{\circ}, 3$, da Lei n. 101/2001).

${ }^{696}$ Disposição semelhante à existente nas legislações portuguesa, no artigo $5^{\circ}, 4$, da Lei 101/2001, argentina, no artigo $6^{\circ}, b$, da Lei n. 24.424, e espanhola, no artigo 282 bis, 1, da Ley de Enjuiciamiento Criminal.

697 A segurança dos agentes infiltrados é um domínio sensível, quer por atuarem lado a lado com os investigados, quer por estarem sujeitos a eventuais represálias. Por isso, merece ele proteção não apenas material, mas também formal, a fim de evitar e prevenir eventuais retaliações que ele possa vir a sofrer por parte do investigado, objeto de sua intervenção. (Manuel Monteiro Guedes Valente, Manuel João Alves e Fernando Gonçalves, $O$ novo regime jurídico..., ob. cit., p. 88).

Disposições semelhantes nas legislações espanhola (artigo 282 bis, 2, da Ley de Enjuiciamiento Criminal) e portuguesa (artigo $4^{\circ}, 3$, da Lei 101/2001).

698 “Art. $7^{\circ}$ Os programas compreendem, dentre outras, as seguintes medidas, aplicáveis isolada ou cumulativamente em benefício da pessoa protegida, segundo a gravidade e as circunstâncias de cada caso:

I - segurança na residência, incluindo o controle de telecomunicações;

II - escolta e segurança nos deslocamentos da residência, inclusive para fins de trabalho ou para a prestação de depoimentos; 
$\S 5^{\circ}$. O depoimento do agente infiltrado protegido pela preservação do sigilo apenas terá relevância probatória quando corroborados por outros elementos de prova. ${ }^{699}$

Art. 80. Ninguém será obrigado a atuar de forma

infiltrada. $^{700}$

Art. $9^{\circ}$. Não é punível a conduta do agente infiltrado que, no decorrer da operação, praticar condutas típicas como consequiência necessária da infiltração, desde que tais condutas guardem uma relação de proporcionalidade com a finalidade da mesma e não constituam risco à vida ou à integridade física de terceiros. ${ }^{701}$

III - transferência de residência ou acomodação provisória em local compativel com a proteção;

$I V$ - preservação da identidade, imagem e dados pessoais;

$V$ - ajuda financeira mensal para prover as despesas necessárias à subsistência individual ou familiar, no caso de a pessoa protegida estar impossibilitada de desenvolver trabalho regular ou de inexistência de qualquer fonte de renda;

VI - suspensão temporária das atividades funcionais, sem prejuízo dos respectivos vencimentos ou vantagens, quando servidor público ou militar;

VII - apoio e assistência social, médica e psicológica;

VIII - sigilo em relação aos atos praticados em virtude da proteção concedida;

$I X$ - apoio do órgão executor do programa para o cumprimento de obrigações civis e administrativas que exijam o comparecimento pessoal.

Parágrafo único. A ajuda financeira mensal terá um teto fixado pelo conselho deliberativo no início de cada exercício financeiro".

${ }^{699}$ Conforme já sustentamos (ver Item 3.7, supra), entendemos que, para subsidiar uma condenação, as declarações do agente infiltrado devem vir acompanhadas de outros elementos de prova que a corroborem. O Projeto de Lei do Senado n. 67/1996 traz disposição semelhante, como se vê:

“Art. 38. O depoimento da testemunha e as declarações da vítima ou do acusado-colaborador protegidos pela preservação do sigilo apenas terão relevância probatória quando roborados por outros meios de prova”.

${ }^{700}$ Como visto, a atuação infiltrada representa, para o agente, grande fonte de ansiedade e exposição extraordinária ao perigo, além de significar longos períodos distantes de sua família e de sua rede social. (Isabel Oneto, $O$ agente infiltrado..., ob. cit., pp. 86-87). Por isso, à semelhança dos legisladores português (artigo $3^{\circ}$, 2, da Lei n. 101/2001) argentino (artigo $8^{\circ}$ da Lei n. 24.424) e espanhol (artigo 282 bis, 2, da Ley de Enjuiciamiento Criminal), entendemos não ser possível determinar a infiltração de alguém contra a sua vontade.

${ }^{701}$ Como visto, o cometimento de delitos é praticamente inerente à atividade do agente infiltrado, uma vez que somente assim ele não criará desconfianças por parte dos investigados e poderá dar sequência à investigação. Assim, pode-se dizer que a regulamentação legal da prática de condutas típicas por parte do agente ao longo da operação infiltrada é imprescindível à própria eficácia da investigação. Conforme sustenta Fernando Gascón Inchausti, a regulamentação legal desta prática "serve simultáneamente a incrementar el grado de eficácia de esta técnica investigadora - si el agente encubierto tuvise prohibida la comisión de delitos su infiltración sería prácticamente ilusória - así como a otorgar mayor seguridad jurídica a los agente dispuestos a ponerla en práctica”. (Fernando Gascón Inchausti, Infiltración policial..., ob. cit., p. 274). Note-se que a regulamentação legal é necessária também para delimitar quais tipos de delitos o agente 
$\S 1^{\circ}$. É vedada ao agente a provocação de delitos.

$\S 2^{\circ}$. Caso seja instaurado procedimento penal para apurar ato praticado por agente na constância da infiltração, o Juiz competente deve, logo que tome conhecimento de tal fato, pedir informações ao Juiz que autorizou a infiltração. ${ }^{702}$

Art. $\mathbf{1 0}^{\circ}$. Esta Lei entra em vigor na data de sua publicação.

Art. $11^{\circ}$. Revogam-se as disposições em contrário.

está autorizado a cometer no decorrer da infiltração, tomando-se por base, para isso, os princípios da necessidade e da proporcionalidade - ou seja, "deve ser observado, naquele caso concreto, se o cometimento daquele crime é necessário e se ele se justifica em prol do valor maior protegido, qual seja, a proteção à sociedade”. (Mariângela Lopes Neistein, O agente infiltrado..., ob. cit., p. 149).

${ }^{702}$ Disposições semelhantes nas legislações portuguesa (artigo 6 ${ }^{\circ}, 2$, da Lei n. 101/2001), espanhola (artigo 282 bis, 5, do Codigo de Enjuiciamiento Criminal) e argentina (artigo $7^{\circ}$ da Lei n. 24.424). 


\section{CONCLUSÃO}

O fenômeno da criminalidade organizada é antigo. Possui, como fatores comuns, as origens rurais, como forma de proteção das populações camponesas contra arbitrariedades cometidas por aqueles que detinham o poder, ou mesmo contra as condições de abandono e desamparo às quais eram relegadas pelo Estado. Esses movimentos contaram com a conivência, e em certos casos até mesmo com o apoio, de autoridades corruptas das regiões onde se desenvolviam.

No Brasil, o antecedente mais remoto da criminalidade organizada seria o movimento chamado cangaço, atuante no sertão nordestino entre o final do século XIX e o início do Século XX. Posteriormente, no início do século XX, surgiu a prática contravencional do conhecido "jogo do bicho", que é reconhecido como a primeira manifestação da criminalidade organizada no Brasil.

A expressão "criminalidade organizada" foi empregada, primeiramente, nos Estados Unidos da América, na década de 1920. O conceito era utilizado, principalmente, para identificar a máfia de origem siciliana que atuava na América, naquele ramo de atividades ilícitas.

Hoje, a mesma expressão é empregada de maneira mais abrangente, tornando-se até mesmo inadequado. Contribui para a incerteza na determinação da real acepção da expressão a pluralidade de formatos assumidos pelas organizações. No entanto, algumas das características apresentadas pelas organizações criminosas, embora fluidas e bastante variáveis conforme o tempo e o local de observação, permitem, de maneira geral, distingui-las, com um bom grau de seguranças dos demais fenômenos criminológicos.

O processo clássico de tipificação penal, modelado para as condutas individualizadas observadas ao longo do século XIX e meados do século XX, passou a ser insuficiente para tutelar as condutas que compõem o crime organizado. $\mathrm{O}$ uso dos tipos penais contra o crime organizado requere uma estrutura penal e processual diferente dos delitos clássicos. 
No Brasil, foi promulgada a Lei 10.217 de abril de 2001, que não se mostrou suficiente para solucionar o problema conceitual do crime organizado no direito brasileiro, vez que permanece silente quanto à definição do fenômeno.

Apenas a existência de conceituação legal do fenômeno da criminalidade organizada pode autorizar o emprego de meios de investigação de provas que acarretem a restrição de direitos e garantias do cidadão, tais como a infiltração de agentes, nos termos do princípio da legalidade. Não se podem empregar meios investigação excepcionais, que restrinjam direitos fundamentais do indivíduos, sem que o crime que tais meios pretendam reprimir esteja previsto em lei anterior. A definição é necessária, também, para que se saiba quais os limites que devem ser seguidos em caso de uma ação investigativa em que haja eventual restrição de garantias fundamentais.

Percebe-se que, nos últimos anos, a sociedade global vem assistindo, perplexa, a uma importante mudança, tanto na forma de execução dos delitos quanto no modo de repressão dos mesmos. No novo cenário criminológico e políticocriminal, a agressividade da delinqüência organizada, combinada com as tentativas estatais - urgentes e sem freios - de controlá-la, implicam grave risco aos valores e princípios inspiradores do Estado Democrático de Direito. ${ }^{703}$

De fato, a criminalidade organizada emerge sem fronteiras quer geográficas, quer morais -, e foge ao âmbito de controle estatal. Os meios tradicionais de controle penal dos Estados mostram-se impotentes para fazer frente a essa nova delinqüência que se espalha pelas mais diversas áreas ${ }^{704}$; motivo pelo qual são criados novos meios de investigação de provas voltados especialmente para esta gama de crimes como é o caso da infiltração de agentes, que foi objeto deste trabalho.

Dentro desse contexto, e insuficientes os meios de investigação de provas tradicionais, entendemos ser a infiltração de agentes meio legítimo para a investigação de provas nos crimes relacionados à criminalidade organizada, desde que, em sua implementação, se façam respeitar os limites impostos pelos direitos e garantias fundamentais dos indivíduos, resguardados por nossa Constituição da República.

\footnotetext{
${ }^{703}$ Marta Gómez de Liaño Fonseca-Herrero, Criminalidad..., ob. cit., p. 29.

${ }^{704}$ Francis Rafael Beck, Perspectivas..., ob. cit., p. 47.
} 
Para que isso ocorra, acreditamos ser necessária, primeiramente, uma regulamentação legal satisfatória e abrangente em torno do fenômeno da criminalidade organizada, sob pena de ferir-se o princípio constitucional da legalidade.

Note-se que a infiltração de agentes configura um meio de investigação ou de pesquisa de provas, visto que é um procedimento regulamentado por nosso ordenamento jurídico, com o objetivo de obter elementos de prova; não sendo, no entanto, em si, fonte de conhecimento.

Isso posto, deve-se atentar para o caráter de excepcionalidade da infiltração de agentes, a qual apenas poderá ser empregada para a investigação de provas em situações que envolvam a delinqüência organizada - não podendo, jamais, assumir a forma de um "comportamento normal" da investigação criminal ${ }^{705}$. É inadmissível a "generalização" do emprego do agente infiltrado como "mero processo de facilitar as acções de investigação elou de prevenção criminais". ${ }^{706}$

Conforme lembra Joaquim Loureiro, “a utilização de 'agentes infiltrados' traduz-se sempre na violação de princípios de relevância constitucional, tanto no que se refere à organização e funções das entidades da investigação criminal, como na violação dos direitos, liberdades e garantias de cidadãos. (...) E, por outro lado, porque a utilização de 'agentes infiltrados' traduz-se sempre na violação de direitos da pessoa: $O$ direito ao silêncio, no sentido do argüido não ser obrigado a colaborar com a 'acusação' ou forças policiais, no sentido de não estar obrigado a auto incriminar-se, ou o mero direito de estar calado. (...) Direito à reserva e intimidade da vida privada. Inviolabilidade de domicílio e de correspondência, etc." ${ }^{707}$ Assim, ainda segundo o mesmo autor, a utilização deste meio de investigação de provas deverá “obedecer a requisitos muito apertados: princípio da proporcionalidade (adequação e necessidade); que os restantes métodos se revelem absolutamente ineficazes; verificação cumulativa destes requisitos; prévia recolha de elementos objectivos capazes de demonstrar 'fortes indícios' de que se está perante um suspeito da prática de crime

\footnotetext{
705 Joaquim Loureiro, Agente infiltrado? Agente provocador! - Reflexões sobre o $1^{o}$ acórdão do T.E.D. Homem - 9.junho. 1998 - Condenação do Estado português. Coimbra: Almedina, 2007, p. 284.

${ }^{706}$ Joaquim Loureiro, Agente infiltrado?..., ob. cit., p. 284.

${ }^{707}$ Joaquim Loureiro, Agente infiltrado?..., ob. cit., p. 285.
} 
previsto; controle da acção através do Magistrado, necessidade de órgãos de polícia criminal respeitarem princípios legais, deontológicos e morais (lealdade)”. ${ }^{708}$

Além disso, e com vistas à limitação do poder estatal - o qual apenas estará autorizado a agir quando a restrição dos direitos fundamentais se mostrar pertinente e proporcional ao alcance dos fins pretendidos ${ }^{709}$-, a medida unicamente poderá ser aplicada quando atender a todos os requisitos e pressupostos do princípio da proporcionalidade. Dessa forma, além de ser a infiltração de agentes determinada por decisão motivada e emitida por juiz competente, é fundamental que ela satisfaça aos ditames da adequação, da necessidade e da proporcionalidade em sentido estrito. Apenas assim restará justificada a adoção de medidas excepcionais de restrição a direitos individuais - como a infiltração de agentes - em relação ao crime organizado. ${ }^{710}$

Importante destacar, ainda, que, devido às intensas restrições aos direitos e liberdades individuais acarretados pela infiltração policial, não se deve admitir a prolação de sentença condenatória apoiada apenas e tão-somente em elementos probatórios obtidos por meio desta medida. Tampouco se pode aceitar sentença condenatória cujo fundamento único é a declaração testemunhal de policial infiltrado. É necessário, em ambos os casos, que existam outros elementos probatórios a dar amparo à sentença.

No entanto, para que se possa, de fato, compatibilizar a atuação do agente infiltrado com os direitos fundamentais garantidos por nossa Constituição da República, faz-se urgente a edição de novo diploma legal para melhor regulamentar este meio de investigação, determinando o prazo máximo para a infiltração, os objetivos da medida, os limites para o cometimento de delitos por parte do infiltrado, a forma como se dará o controle judicial sobre a operação, o modo de valoração do resultado probatório obtido pelo agente, a troca de identidade do agente e as medidas de proteção a que este tem direito, a forma de sigilo dos autos, o procedimento para oitiva do infiltrado, entre outros. Imprescindível, ainda, que se elabore um conceito jurídico-penal de crime

\footnotetext{
${ }^{708}$ Joaquim Loureiro, Agente infiltrado?..., ob. cit., p. 285.

${ }^{709}$ Fábio Roque da Silva Araújo, O princípio da proporcionalidade aplicado ao direito penal: fundamentação constitucional da legitimidade e limitação do poder de punir. Revista Brasileira de Ciências Criminais. São Paulo: Revista dos Tribunais, n. 80, ano 17, set.-out./2009, p. 54.

${ }^{710}$ Antonio Scarance Fernandes, Equilíbrio..., ob. cit., p. 237.
} 
organizado. Entendemos que apenas com essas reformas legislativas é possível combater a delinqüência organizada de maneira eficiente, com respeito ao princípio da legalidade e às garantias constitucionais do indivíduo.

Assim sendo, cremos de suma importância que, ao mesmo tempo em que se busca o aprimoramento do modelo repressivo penal, buscando compatibilizar as técnicas de investigação existentes - tais como a infiltração de agentes com as garantias oferecidas por nossa Constituição da República, se procure criar um conjunto de medidas preventivas eficazes contra a criminalidade organizada. Entendemos que esta pode ser a chave para que, finalmente, se possa controlar esse tipo de delinqüência tão resistente às formas de combate tradicionais, evitando-se um açodamento precipitado dos direitos e garantias do acusado ou investigado, buscando-se, enfim, um equilíbrio entre garantismo e eficiência na repressão a esse tipo de delito. 


\section{REFERÊNCIAS BIBLIOGRÁFICAS}

\section{i) Livros, artigos e periódicos:}

ABADINSKY, Howard. Organized crime. Chicago: Nelson Hall, 1992.

ALBANESE, Jay. Organized crime in America. Cincinnati: Anderson, 1985.

ALSINA, Hugo. Tratado teórico práctico de derecho procesal civil y comercial. Buenos Aires: Ediar, 1961.

ANDRADE, Manuel da Costa. Métodos ocultos de investigação (Plädoyer para uma teoria geral). Justiça penal portuguesa e brasileira - tendências de reforma. Colóquio em homenagem ao Instituto Brasileiro de Ciências Criminais. São Paulo: IBCCrim, 2008.

ARANHA FILHO, José Antônio Pinheiro. Implicações sobre a figura do agente infiltrado. Artigo disponível no endereço eletrônico: www.ibccrim.org.br, em 17 de junho de 2003.

ARAÚJO, Fábio Roque da Silva. O princípio da proporcionalidade aplicado ao direito penal: fundamentação constitucional da legitimidade e limitação do poder de punir. Revista Brasileira de Ciências Criminais. São Paulo: Revista dos Tribunais, n. 80, ano 17 , set.-out./2009.

AZEVEDO, Bernardo Montalvão Varjão de; e VILLAS BÔAS, Marcos de Aguiar. Proporcionalidade e suas repercussões nas ciências criminais. Revista Brasileira de Ciências Criminais. São Paulo: Revista dos Tribunais, n. 74, ano 16, set.-out./2008.

AZEVEDO, David Teixeira de. A colaboração premiada num direito ético. Boletim IBCCrim. São Paulo, n. 83, out. 1999.

AQUINO, José Carlos G. Xavier de. A prova testemunhal no processo penal brasileiro. São Paulo: Juarez de Oliveira, 2002.

BACIGALUPO, Enrique. El debido proceso penal. Buenos Aires: Hammurabi, 2005. . Manual de Derecho Penal, parte geral. Bogotá: Temis-Ilanud, 1984.

BADARÓ, Gustavo Henrique Righi Ivahy. Ônus da prova no processo penal. São Paulo: Revista dos Tribunais, 2003.

leis - IBCCrim. Artigo disponível no endereço eletrônico: http://www.ibccrim.org.br/site/estudosPesquisas/estudosProjetos.php?tipo=selProjeto s\&id=166\#, em 23 de novembro de 2009. 
BARROS, Suzana de Toledo. O princípio da proporcionalidade e o controle de constitucionalidade das leis restritivas de direitos fundamentais. Brasília: Brasília Jurídica, 2003.

BECCARIA, Cesare. Dos delitos e das penas. São Paulo: Martin Claret, 2002.

BECHARA, Fábio Ramazzini; e MANZANO, Luís Fernando de Moraes. Crime organizado e terrorismo nos Estados Unidos da América. In: Crime organizado aspectos processuais. São Paulo: Revista dos Tribunais, 2009.

BECK, Francis Rafael. Perspectivas de controle ao crime organizado e crítica à flexibilização das garantias. São Paulo: IBCCrim, 2004.

BELLOQUE, Juliana Garcia. Sigilo bancário - análise crítica da LC 105/2001. São Paulo: Revista dos Tribunais, 2003.

BERALDO, Luís Fernando Silveira. Limites aos poderes instrutórios do juiz criminal. Dissertação de mestrado apresentada à Faculdade de Direito da Universidade de São Paulo. São Paulo: USP, 2006.

BERTOLINO, Pedro J.. El debido proceso penal. La Plata: Platense, 1986.

BETANHO, Luiz Carlos. O cone do silêncio à brasileira. Boletim IBCCrim, São Paulo, n. 30, junho/1995.

BINDER, Alberto M.. Introdução ao Direito Processual Penal. Rio de Janeiro: Lumen Juris, 2003.

BULOS, Uadi Lammêgo. Curso de Direito Constitucional. São Paulo: Saraiva, 2007.

BUONO, Carlos Eduardo de Athayde e BENTIVOGLIO, Antonio Tomás. O crime organizado. Boletim IBCCrim, São Paulo, n. 21, setembro/1994.

CAÇAPAVA, Elisa Pires da Cruz Reale; e VILARES, Fernanda Regina. Crime organizado e terrorismo na França. In: Crime organizado - aspectos processuais. São Paulo: Revista dos Tribunais, 2009.

CALAMANDREI, Piero. Proceso y democracia. Buenos Aires: EJEA, 1960.

CALLEGARI, André Luis; e WERMUTH, Maiquel Ângelo Dezordi. Crime organizado: conceito e possibilidade de tipificação diante do contexto de expansão do direito. Revista Brasileira de Ciências Criminais. São Paulo: Revista dos Tribunais, n. 79, ano 17, jul.-ago./2009.

CANCIO MELIÁ, Manuel, e Paula Andrea Ramírez Barbosa. Crime organizado Tipicidade, política criminal, investigação e processo - Brasil, Espanha e Colômbia. Coord.: André Luís Callegari. Porto Alegre: Livraria do Advogado, 2008.

CASSANI, Belén. Agente encubiertos e informantes como medios de prueba contra el crimen organizado - Um análises desde la jurisprudencia de derechos humanos. In: El crimen organizado - Desafios y perspectivas en el marco de la globalización. Buenos Aires: Editorial Ábaco de Rodolfo Depalma, 2005. 
CASTANHEIRA, Beatriz Rizzo. Organizações criminosas no direito penal brasileiro: o estado de prevenção e o princípio da legalidade estrita. Revista Brasileira de Ciências Criminais, São Paulo, ano 6, n. 24, out.-dez./1998.

CASTELO BRANCO, Tales. Da prisão em flagrante. São Paulo: Saraiva, 2001.

CERVINI, Raúl. Análise criminológica do fenômeno do delito organizado. Trad. De Oswaldo Henrique Duek Marques, in Ciência e política criminal, em honra de Heleno Fragoso. Org. João Marcello de Araújo Júnior. Rio de Janeiro: Forense, 1992.

CIRINO DOS SANTOS, Juarez. A moderna teoria do fato punível. Rio de Janeiro: Freitas Bastos, 2000.

Crime organizado. Revista Brasileira de Ciências Criminais. São Paulo: Revista dos Tribunais, n. 42, jan.-mar./2003.

COMOGLIO, Luigi Paolo. Lessico delle prove e modello acusatório. Rivista di diritto processuale, ano L (segunda série), n. 4, out.-dez./1995. Milano: Cedam, 1995.

COSTA, Renata Almeida da. Sociedade complexa $e$ o crime organizado: $a$ contemporaneidade e o risco nas organizações criminosas. Rio de Janeiro: Lumen Juris, 2004.

COSTA JR., Paulo José da. O direito de estar só - A tutela penal do direito à intimidade. São Paulo: Siciliano, 2004.

COVELLO, Sérgio Carlos. O sigilo bancário: com particular enfoque na sua tutela civil. São Paulo: Universitária do Direito, 2001.

DAVIN, João. A criminalidade organizada transnacional - A cooperação judiciária $e$ policial na UE. Coimbra: Almedina, 2007.

DELMANTO JUNIOR, Roberto. As modalidades de prisão provisória e seu prazo de duração. Rio de Janeiro / São Paulo: Renovar, 2001.

; DELMANTO, Celso; DELMANTO, Roberto; e DELMANTO, Fabio M. de Almeida. Código Penal Comentado. São Paulo: Renovar, 2007.

DOTTI, René Ariel. A organização criminosa é uma forma qualificada do concurso de pessoas. Boletim IBCCrim. São Paulo, ano 17, n. 198, maio/2009.

A falácia das novas leis penais contra o crime organizado (I). Migalhas, 23 de janeiro de 2007. Artigo disponível no endereço eletrônico: http://www.migalhas.com.br/mostra_noticia_articuladas.aspx?cod=34600, em 19 de novembro de 2009.

DUARTE, Luiz Carlos Rodrigues. Princípio vitimológico e criminalidade organizada. In: Criminalidade moderna e reformas penais - Estudos em homenagem ao Prof. Luiz Luisi. Porto Alegre: Livraria do Advogado, 2001. 
D’URSO, Luiz Flávio Borges. Lei nova autoriza infiltração de policiais em quadrilhas. Artigo disponível no endereço eletrônico: www.ibccrim.com.br, em agosto de 2005.

EDWARDS, Carlos Enrique. El arrepentido, el agente encubierto y la entrega vigilada. Modificación a la ley de estupefacientes. Análisis de la ley 24.424. Buenos Aires: Ad-Hoc, 1996.

EL HIRECHE, Gamil Föppel. Análise criminológica das organizações criminosas: da inexistência à impossibilidade de conceituação e suas repeercussões no ordenamento jurídico pátrio. Manifestação do direito penal do inimigo. Rio de Janeiro: Lumen Juris, 2005.

FERRAJOLI, Luigi. Direito e razão - teoria do garantismo penal. São Paulo: Revista dos Tribunais, 2006.

FIGUEIREDO, Frederico. Política criminal populista: para uma crítica do direito penal instrumental. Revista Brasileira de Ciências Criminais. São Paulo: Revista dos Tribunais, ano 16, n. 70, jan.-fev./2008.

FIGUEIREDO DIAS, Jorge de. A criminalidade organizada: do fenómeno ao conceito jurídico-penal. In: Revista Brasileira de Ciências Criminais, São Paulo, n. 71, ano 16, mar.-abr./2008.

Direito Penal - Parte geral - tomo I. São Paulo/Coimbra: Revista dos Tribunais/Coimbra Editora (co-edição), 2007.

FONSECA-HERRERO, Marta Gómez de Liaño. Criminalidad organizada y médios extraordinarios de investigación. Madrid: COLEX, 2004.

FRANCO, Alberto Silva. Um difícil processo de tipificação. Boletim IBCCrim. São Paulo, ano 2, n. 21, set./1994.

Crimes hediondos. São Paulo: Revista dos Tribunais, 2005.

. Leis penais especiais e sua interpretação jurisprudencial. São Paulo: Revista dos Tribunais, 2002.

GARCÍA, Maria Dolores Delgado. El agente encubierto: técnicas de investigación. Problemática y legislación comparada. In: CONRADI, Faustino Gutiérrez-Alviz (org.). La criminalidad organizada ante la Justicia. Sevilla: Universidad de Sevilla, 1996.

GAYRAUD, Jean-François. Le monde des mafias - géopolitique du crime organisé. Paris: Odile Jacob: 2005.

GEMAQUE, Silvio César Arouck; e RUSSO, Luciana. Crime organizado em Portugal. In: Crime organizado - aspectos processuais. São Paulo: Revista dos Tribunais, 2009.

GOMES FILHO, Antonio Magalhães. Também em matéria processual provoca inquietação a Lei Anti-Crime Organizado. Boletim IBCCrim, São Paulo, n. 13, fev./1994. 
A violação do princípio da proporcionalidade pela Lei n. 9.296/96. Boletim IBCCrim, São Paulo, edição especial n. 45, ago./1996.

Revista dos Tribunais, 2001. - A motivação das decisões penais. São Paulo:

Revista dos Tribunais, 1997.

. Direito à prova no processo penal. São Paulo:

Saraiva, 1991.

Presunção de inocência e prisão cautelar. São Paulo:

Notas sobre a terminologia da prova (reflexos no processo penal brasileiro). In: Estudos em homenagem à professora Ada Pellegrini Grinover. Org.: Flávio Luiz Yarshell e Maurício Zanóide de Moraes. São Paulo: DPJ, 2005.

; FERNANDES, Antonio Scarance; e GRINOVER, Ada Pellegrini. As nulidades no processo penal. São Paulo: Revista dos Tribunais, 2004.

; e BADARÓ, Gustavo Henrique Righi Ivahy. Prova e sucedâneos de prova no processo penal brasileiro. Revista Brasileira de Ciências Criminais. São Paulo, v. 15, fasc. 65, mar.-abr./2007.

GOMES, Luiz Flávio; e CERVINI, Raúl. Crime organizado: enfoques criminológico, jurídico (Lei 9.034/95) e político-criminal. São Paulo: Revista dos Tribunais, 1997.

Crime organizado: o que se entende por isso depois da Lei $\mathrm{n}^{\circ}$ 10.217, de 11.04.2001? - Apontamentos sobre a perda de eficácia de grande parte da Lei n ${ }^{\circ}$ 9.034/95. Revista Síntese de Direito Penal e Processual Penal. São Paulo, ano II, ${ }^{\circ} 11$, dez.-jan./2002.

Definição de crime organizado e a Convenção de Palermo. Artigo disponível no endereço eletrônico http://www.lfg.com.br em 06 de maio de 2009.

GOMES, Rodrigo Carneiro Gomes, O crime organizado na visão da Convenção de Palermo. Belo Horizonte: Del Rey, 2009.

GONZALEZ-CUELLAR SERRANO, Nicolas. Proporcionalidad y derechos fundamentales en el proceso penal. Madri: Colex, 1990.

GRECO, Rogério. Curso de Direito Penal - Parte geral, volume 1. Rio de Janeiro: Impetus, 2007.

GRECO FILHO, Vicente. Interceptação telefônica: considerações sobre a lei $n$. 9.296, de 24 de julho de 1996. São Paulo: Saraiva, 1996.

Tutela constitucional das liberdades. São Paulo: Saraiva, 1989.

GREVI, Vittorio. Nemo tenetur se detegere - interrogatorio dell'imputato e diritto al silenzio nel processo penale italiano. Milano: Giuffrè, 1972. 
GRINOVER, Ada Pellegrini. Que juiz inqusidor é esse? Boletim IBCCrim, São Paulo, n. 30, junho/1995.

A legislação brasileira em face do crime organizado. Revista Brasileira de Ciências Criminais, São Paulo, ano 5, n. 20, out.-dez./1997.

- Liberdades públicas e processo penal - As interceptações telefônicas. São Paulo: RT, 1982.

. O conteúdo da garantia do contraditório. In: Novas tendências do Direito Processual (de acordo com a Constituição de 1988). Rio de Janeiro: Forense Universitária, 1990.

Penal, n. 1, ano III, 1976.

Interrogatório do réu e direito ao silêncio. Revista Ciência

GUIMARÃES, Isaac Sabbá. O agente infiltrado na investigação das associações criminosas. Boletim IBCCrim. São Paulo, v. 10, n. 117, ago./2002.

HASSEMER, Winfried. Segurança pública no Estado de Direito. In: Revista Brasileira de Ciências Criminais, São Paulo, ano 2, n. 5, jan.-mar./1994.

HUNGRIA, Nelson. Comentários ao Código Penal, v. 1, t. 2. Rio de Janeiro: Forense, 1955.

IBÁÑEZ, Perfecto Andrés. Sobre a motivação dos fatos na sentença penal. In: Valoração da prova e sentença penal. Rio de Janeiro: Lumen Juris, 2006.

INCHAUSTI, Fernando Gascón. Infiltración policial y agente encubierto. Granada: Comares, 2001.

JESUS, Damásio E. de. O fracasso da delação premiada. Boletim IBCCrim. São Paulo, n. 21, set./1994.

; e BECHARA, Fábio Ramazzini. Agente infiltrado: reflexos penais e processuais. Revista Juz Vigilantibus, 11 de outubro de 2005. Artigo disponível no endereço eletrônico: http://jusvi.com/artigos/17889, em 07 de outubro de 2009.

JOSÉ, Maria Jamile; e COGAN, Marco Antônio Pinheiro Machado. Crime organizado e terrorismo na Espanha. In: Crime organizado - aspectos processuais. São Paulo: Revista dos Tribunais, 2009.

KINZIG, Jorg. Mesures de lutte contre la criminalité organizée em Allemagne. In: Criminalité organisée - des représentations sociales aux définitions juridiques. Paris: L.G.D.J; Bruxelles: Bruylant; Genève: Georg, 2004.

LABORDE, Jean-Paul. État de droit et crime organisé. Paris: Dalloz, 2005.

LARONGA, Antonio. Le prove atipiche nel processo penale. Milano: CEDAM, 2002. 
LIPINSKI, Antonio Carlos. Crime organizado e a prova penal - Lei 9.034, de 03.05.1995. Curitiba: Juruá, 2006.

LOPES JR., Aury. Introdução crítica ao Processo Penal (Fundamentos da instrumentalidade constitucional). Rio de Janeiro: Lumen Juris, 2006.

LOUREIRO, Joaquim. Agente infiltrado? Agente provocador! - Reflexões sobre o $1^{o}$ acórdão do T.E.D. Homem - 9.junho.1998 - Condenação do Estado português. Coimbra: Almedina, 2007.

LYMAN, Michael D.; e POTTER, Gary W.. Organized Crime. New Jersey: Pearson Prentice Hall, 2007.

MACHADO, André Augusto Mendes; e KEHDI, André Pires de Andrade. Sigilo das comunicações e de dados. In: Sigilo no processo penal - eficiência e garantismo. Coord.: Antonio Scarance Fernandes, José Raul Gavião de Almeida e Maurício Zanóide de Moraes. São Paulo: Revista dos Tribunais, 2008.

MACIEL, Adhemar Ferreira. Observações sobre a lei de repressão ao crime organizado. Revista Brasileira de Ciências Criminais. São Paulo: Revista dos Tribunais, out.dez.1995.

MANZINI, Vicenzo. Tratado de derecho procesal penal. Trad.: Santiago Sentís Melendo. Buenos Aires: Europa-América, 1951.

MARTÍN, Joaquín Delgado. El proceso penal ante la criminalidad organizada. Revista actualidad penal, n. 1, 2000-2001.

MATA-MOUROS, Fátima. O agente infiltrado. Revista do Ministério Público. Lisboa, v. 22, n. 85, jan.-mar./2001.

MEIREIS, Manuel Augusto Alves. O regime das provas obtidas pelo agente provocador em processo penal. Coimbra: Coimbra Editora, 1999.

MENDRONI, Marcelo Batlouni. Crime organizado - aspectos gerais e mecanismos legais. São Paulo: Atlas: 2007.

MENDES DE ALMEIDA, Joaquim Canuto. A liberdade jurídica no direito e no processo. Estudos jurídicos em homenagem a Vicente Ráo. São Paulo: Resenha Universitária, 1976.

Paulo: Revista dos Tribunais, 1973.

Princípios fundamentais do processo penal. São

MINGARDI, Guaraci. O Estado e o crime organizado. São Paulo: Instituto Brasileiro de Ciências Criminais, 1998.

MITTERMAYER, Karl Joseph Anton. Tratado da prova em matéria criminal. Rio de Janeiro: Jacinto, 1917.

MOCCIA, Sergio Moccia, La perenne emergenza. Napoli: Scientifiche Italiane, 1997. 
MONTOYA, Mario Daniel. Informantes y técnicas de investigación encubiertas. Buenos Aires: Ad-Hoc, 2001.

. Máfia e crime organizado. Rio de Janeiro: Lumen Juris, 2007.

MORAES, Maurício Zanóide de. Publicidade e proporcionalidade na persecução penal brasileira. In: Sigilo no processo penal - eficiência e garantismo. São Paulo: Revista dos Tribunais, 2008

Sigilo financeiro: LC 105, de 10.01.2001. In: Leis penais especiais e sua interpretação jurisprudencial. São Paulo: Revista dos Tribunais, 2001.

MOURA, Maria Thereza Rocha de Assis. Delação premiada. Revista Del Rey Jurídica. Belo Horizonte, ano 8, n. 16, $1^{\circ}$ sem./2006.

MUÑOZ SANCHES, Juan. El agente provocador. Valencia: Tirant lo Blanch, 1995.

NEISTEIN, Mariângela Lopes. $O$ agente infiltrado como meio de investigação. Dissertação de mestrado apresentada à Faculdade de Direito da Universidade de São Paulo. São Paulo: USP, 2006.

NUCCI, Guilherme de Souza. Código penal comentado. São Paulo: Revista dos Tribunais, 2006.

ONETO, Isabel. $O$ agente infiltrado - contributo para a compreensão do regime jurídico das acções encobertas. Coimbra: Coimbra Editora, 2005.

ORSI, Omar Gabriel. Sistema penal y crimen organizado - Estrategias de aprehensión y criminalización del conflicto. Buenos Aires: Editores del Puerto, 2007.

ORTEGA, Juan José Lopez. Infiltración policial y provocación del delito. Revista Española de Derecho Militar. Vol. 70, jul.-dez./1997.

PACHECO, Denílson Feitoza. O princípio da proporcionalidade no direito processual penal brasileiro. Rio de Janeiro: Lumen Juris, 2007.

PACHECO, Rafael. Crime organizado - medidas de controle e infiltração policial. Curitiba: Juruá, 2008.

PAIXÃO, Antonio Luiz. Recuperar ou punir? Como o Estado trata o criminoso. São Paulo: Cortez, 1987.

PAZ, Isabel Sánchez García de. La criminalidad organizada - aspectos penales, procesales, administrativos y policiales. Madrid: Dykinson, 2005.

PITOMBO, Antônio Sérgio Altieri de Moraes. Organização criminosa - nova perspectiva do tipo legal. São Paulo: Revista dos Tribunais, 2009.

PITOMBO, Sérgio Marcos de Moraes. Crime organizado. Artigo disponível no endereço eletrônico www.sergio.pitombo.nom.br em janeiro de 2006. 
Prisão temporária e crise urbana. Revista dos Tribunais. São Paulo, ano 75, vol. 603, jan./1986.

PLANET ROBLES, Sílvia. Políticas de seguridad y prevención en el estado español en materia de delincuencia organizada. La seguridad en la sociedad del riesgo: un debate abierto. Barcelona: Atelier, 2003.

PORTO, Roberto. Crime organizado e sistema prisional. São Paulo: Atlas, 2008.

PRADO, Geraldo; DOUGLAS, William; e GOMES, Abel Fernandes. Crime organizado e suas conexões com o poder público, comentários à Lei $n^{\circ}$ 9.034/95, considerações críticas. Rio de Janeiro: Impetus, 2000.

RÚBIO, José María Paz; et al. La prueba en el proceso penal - su práctica ante los tribunales. Madri: Colex: 1999.

SAAD, Marta. O direito de defesa no inquérito policial. São Paulo: Revista dos Tribunais, 2004.

SALLA, Fernando. Considerações sociológicas sobre o crime organizado no Brasil. Revista Brasileira de Ciências Criminais, São Paulo, n. 71, ano 16, mar.-abr./2008.

SÁNCHEZ, Eduardo Andrade. Instrumentos jurídicos contra el crimen organizado. Universidade Autónoma de México - Poder Judicial de la Federación: México, 1997.

SANTAMARIA, Claudia B. Moscato de. El agente encubierto en el Estado de Derecho. Buenos Aires: La Ley, 2000.

SCARANCE FERNANDES, Antonio. O equilíbrio na repressão ao crime organizado. In: Crime organizado - aspectos processuais. São Paulo: Revista dos Tribunais, 2009.

. O equilíbrio entre a eficiência e o garantismo e o crime organizado. Revista Brasileira de Ciências Criminais, São Paulo, n. 70, ano 16, jan.-fev./2008.

.Reflexões sobre as noções de eficiência e garantismo no processo penal. In: Sigilo no processo penal - eficiência $e$ garantismo. São Paulo: Revista dos Tribunais, 2008.

dos Tribunais, 2005.

. Processo penal constitucional. São Paulo: Revista

. O conceito de crime organizado na Lei 9.034.

Boletim IBCCrim, São Paulo, n. 31, julho/1995.

- Crime organizado e legislação brasileira. In: Justiça Penal 3: críticas e sugestões. O crime organizado (Itália e Brasil). A modernização da lei penal. Coord.: Jaques de Camargo Penteado. São Paulo: Revista dos Tribunais, 1995. 
SERRANO, Nicolas Gozáles-Cuellar. Proporcionalidad y derechos fundamentales en el proceso penal. Madrid: Colex, 1990.

SILVA, Eduardo Araújo da. Crime organizado - procedimento probatório. São Paulo: Atlas, 2003.

. Da moralidade da proteção aos réus colaboradores. Boletim IBCCrim. São Paulo, n. 85, dez./1999.

SPEZIALE, Jerry; e SEAL, Mark. Without a badge - Undercover in the world's deadliest criminal organization. New York: Kensington Books, 2003.

SUANNES, Adauto. Os fundamentos éticos do devido processo penal. São Paulo: Revista dos Tribunais, 1999.

SZNICK, Valdir. Crime organizado - comentários. São Paulo: Leud, 1997.

SOLER, Sebastián. Tratado de derecho penal argentino, tomo II. Buenos Aires. TEA, 1992.

TARUFFO, Michele. La prova dei fatti giuridici - nozioni generali. Milano: Giuffrè, 1992.

Padova, 1984.

.Il diritto alla prova nel processo civile. Rivista di diritto processuale.

TAVARES, Juarez. A violação do sigilo bancário em face da proteção da vida privada. Revista brasileira de ciências criminais, n. 1, jan.- mar./1993.

TOLEDO, Francisco de Assis. Princípios básicos de direito penal. São Paulo: Saraiva, 1994.

TONINI, Paolo. La prova penale. Padova: Cedam, 2000.

. Manuale di Procedura Penale. Milano: Giuffrè, 2007.

TUCCI, Rogério Lauria. Direitos e garantias individuais no processo penal brasileiro. São Paulo: Revista dos Tribunais, 2004.

. Persecução penal, prisão e liberdade. São Paulo: Saraiva, 1980.

e TUCCI, José Rogério Cruz e. Constituição de 1988 e processo. São

Paulo: Saraiva, 1989.

VADILLO, Enrique Ruiz. Garantías del proceso presupuesto del tratamiento del delincuente. Revista de Política Criminal y Reforma Penal. Espanha: Editoriales de Derecho Reunidas.

VALENTE, Manuel Monteiro Guedes. Escutas telefónicas - da excepcionalidade à vulgaridade. Coimbra: Almedina, 2004. 
; ALVES, Manuel João; e GONÇALVES, Fernando. O novo regime jurídico do agente infiltrado. Coimbra: Almedina, 2001.

agente infiltrado versus o agente provocador. Os princípios do processo penal. In: Lei e crime. Coimbra: Almedina, 2001.

VIGNA, Piero L.. La cooperación judicial frente al crimen organizado. In: El crimen organizado - Desafíos y perspectivas en el marco de la globalización. Buenos Aires: Editorial Ábaco de Rodolfo Depalma, 2005.

VILARDI, Rodrigo Garcia; e GÍDARO, Wagner Roby. O crime organizado e o terrorismo na Argentina. In: Crime organizado - aspectos processuais. São Paulo: Revista dos Tribunais, 2009.

VIRGOLINI, Julio E. S.. Crimen organizado: criminología, derecho y política. In: Nada personal... Ensayos sobre crimen organizado y sistema de justicia. Buenos Aires: Depalma, 2001.

YACOBUCCI, Guillermo J.. Política criminal y delincuencia organizada. In: El crimen organizado - Desafíos y perspectivas en el marco de la globalización. Buenos Aires: Editorial Ábaco de Rodolfo Depalma, 2005.

Los tipos penales relacionados con el crimens organizado. In: El crimen organizado - Desafios y perspectivas en el marco de la globalización. Buenos Aires: Editorial Ábaco de Rodolfo Depalma, 2005.

ZAFFARONI, Eugenio Raúl. Crime organizado: uma categorização frustrada. In: Discursos sediciosos, a. 1, v. 1. Rio de Janeiro: Relume/Dumará, 1996.

Globalización y sistema penal en America Latina: de la seguridade nacional a la urbana. A legislação brasileira em face do crime organizado. Revista Brasileira de Ciências Criminais. São Paulo: Revista dos Tribunais, v. 5, n. 20, out.-dez./1997.

En torno al concepto de "crimen organizado". In: Nada personal... Ensayos sobre crimen organizado y sistema de justicia. Buenos Aires: Depalma, 2001.

\section{ii) Documentos eletrônicos:}

http://www.ibccrim.org.br/, acessado a partir de 30 de outubro de 2008.

http://www.fbi.gov/hq/cid/orgcrime/glossary.htm, acessado em 30 de outubro de 2008.

http://www.interpol.int, acessado em 31 de outubro de 2008.

http://www.planalto.gov.br, acessado a partir de 13 de novembro de 2008. 
http://www.leggeonline.info/procedurapenale, acessado em 08 de dezembro de 2008.

http://noticias.juridicas.com/base_datos/Penal/lecr.html, acessado em 05 de outubro de 2009.

http://www.dgpj.mj.pt/DGPJ/sections/leis-da-justica/livro-iv-leis-criminais/pdf4/l-1012001/downloadFile/file/L 101 2001.pdf?nocache $=1182173636.8$, acessado em 05 de outubro de 2009.

http://jusvi.com, acessado em 07 de outubro de 2009.

http://www.infoarda.org.ar/LEY\%2024424.htm, acessado em 27 de outubro de 2009.

http://www.migalhas.com.br, acessado em 19 de novembro de 2009.

www.senado.gov.br, acessado em 23 de novembro de 2009.

http://www.planalto.gov.br/ccivil/Leis/L9807.htm, acessado em 24 de novembro de 2009.

http://www.iuscomp.org/gla/statutes/StPO.htm\#110a, acessado em 24 de novembro de 2009.

http://gtld.pgr.mpf.gov.br/lavagem-de-dinheiro/legislacaointernacional/docs/Convencao_palermo.pdf, acessado em 24 de novembro de 2009.

http://pt.legislacao.org/primeira-serie/lei-n-o-104-2001-criminal-autoridades-policiaautorizacao-151393, acessado em 24 de novembro de 2009.

http://www.legifrance.gouv.fr/affichCode.do?cidTexte=LEGITEXT000006071154\&dateT $\underline{\text { exte }=20091119}$, acessado em 25 de novembro de 2009 .

http://www.receita.fazenda.gov.br/legislacao/decretos/2002/Dec4176.htm, acessado em 03 de dezembro de 2009.

http://www.senado.gov.br/agencia/verNoticia.aspx? codNoticia=91799\&codAplicativo=2, acessado em 03 de dezembro de 2009.

http://legis.senado.gov.br/mate-pdf/8236.pdf, acessado em 03 de dezembro de 2009.

http://www.planalto.gov.br/ccivil/ Ato2004-2006/2006/Lei/L11343.htm, acessado em 08 de dezembro de 2009.

http://www.uncjin.org/Documents/Conventions/dcatoc/final_documents_2/convention_eng .pdf, acessado em 09 de dezembro de 2009.

http://www.aduanaargentina.com/leyes/ca.php, acessado em 09 de dezembro de 2009. 